\title{
Direct Light Activation of Hypervalent lodine Reagents: Substrate-Controlled C-C or C-H Alkynylation of Cyclopropanes
}

Tin V. T. Nguyen and Jerome Waser*a

Laboratory of Catalysis and Organic Synthesis, Institute of Chemical Sciences and Engineering, Ecole Polytechnique Fédérale de Lausanne, EPFL SB ISIC LCSO, BCH 1402, 1015 Lausanne, Switzerland.

\begin{abstract}
We report the direct light activation of ethynylbenziodoxolone (EBX) reagents for the oxyalkynylation of aryl- and amino-cyclopropanes as well as styrenes. Irradiation with visible light at $440 \mathrm{~nm}$ promoted the reaction without the need of a photocatalyst. By the choice of the aryl group on the cyclopropane, it was possilbe to completely switch the outcome of the reaction from the oxyalkynylation of the $\mathrm{C}-\mathrm{C}$ bond to the alkynylation of the $\mathrm{C}-\mathrm{H}$ bond. This effect has been speculatively attributed to the conformational control induced by the aryl group on the cyclopropane ring
\end{abstract}

\section{Introduction}

Hypervalent iodine reagents are now well-established for the functionalization of nucleophiles under mild conditions due to their unique reactivity. ${ }^{1}$ More recently, they have been also successful in the functionalization of radicals. In particular, ethynylbenziodoxolone (EBX) reagents have emerged as excellent radical traps, enabling the synthesis of alkynes otherwise difficult to access (Scheme 1A). ${ }^{2}$ Efficient access toward structurally diverse alkynes is urgently needed, due to their numerous applications in synthetic and medicinal chemistry, chemical biology and organic materials. ${ }^{3}$ The combination of visible-light photocatalysis and EBX reagents has been especially successful, allowing new processes, such as decarboxylative ${ }^{4}$ or deoxygenative alkynylations, ${ }^{5}$ as well as alkene $^{6}$ and $\mathrm{C}-\mathrm{H}$ functionalization. ${ }^{7}$

In contrast, the direct alkynylation of inert C-C bonds is more challenging. The use of the ring strain of cyclopropanes is wellestablished in synthetic chemistry to enable $\mathrm{C}-\mathrm{C}$ bond cleavage. First applied to more reactive Donor-Acceptor systems, ${ }^{8}$ less reactive Donor-only arylcyclopropanes could be also recently functionalized through oxidative activation to give radical cations (Scheme 1B). ${ }^{9}$ Photocatalytic methods have further led to new multi-functionalization reactions. ${ }^{10}$ However, concerning alkynylation, success has been limited for a long time to cyclopropanols, giving access only to ketones as products. ${ }^{11}$ In 2021, Chen and co-workers developed the first photocatalyzed oxyalkynylation of the $\mathrm{C}-\mathrm{C}$ bond of aminocyclopropanes (Scheme 1C1). ${ }^{12}$ During preparation of this manuscript, Studer and co-workers reported in January 2022 the first addition of EBX reagents to the $\mathrm{C}-\mathrm{C}$ bond of arylcyclopropanes (Scheme 1C2). ${ }^{13}$ Both methods required a careful optimization of additives and photocatalyst for success.
A R-EBXs as somophilic alkynylation reagents ${ }^{2,4-7}$

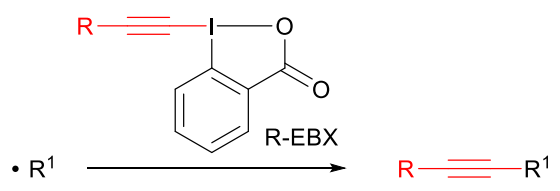

B Oxidative ring-opening of arylcyclopropanes ${ }^{9,10}$

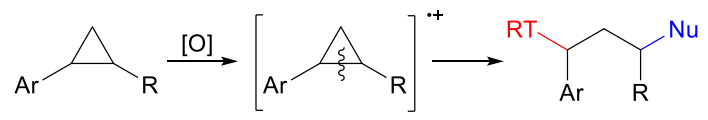

C Photocatalytic oxyalkynylation of cyclopropanes

C.1 Aminocyclopropanes (Chen, 2021) ${ }^{12}$

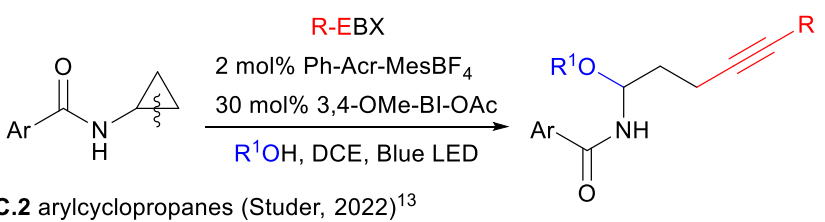

C.2 arylcyclopropanes (Studer, 2022) ${ }^{13}$

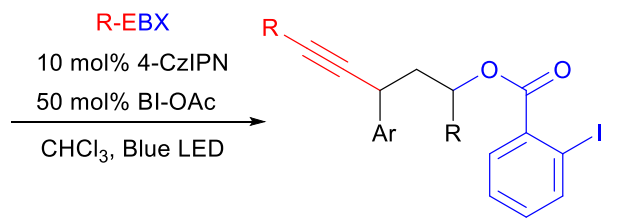

C This work: Direct photoactivation of R-EBXs for $\mathrm{C}-\mathrm{C}$ and $\mathrm{C}-\mathrm{H}$ alkynylation

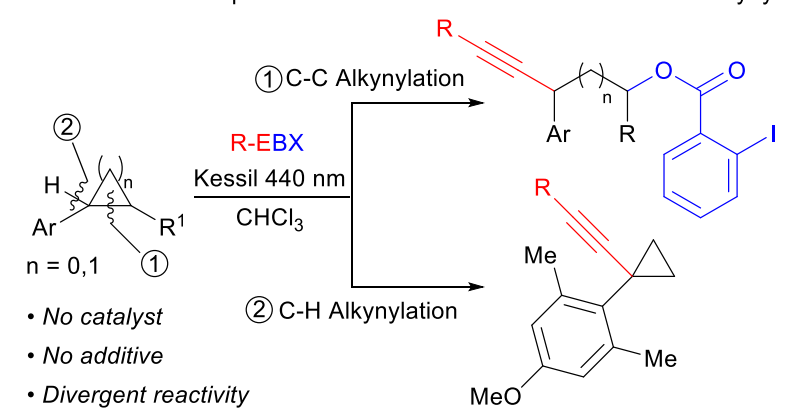

Scheme 1 Combining the unique reactivity of hypervalent iodine reagents and ring strain for the synthesis of multi-functionalized alkynes. $\mathrm{D}=$ Donor, $\mathrm{A}=$ Acceptor, $\mathrm{Nu}=$ Nucleophile, RT = radical trap.

Our group recently discovered the direct visible light activation of aryl-substituted EBX reagents. ${ }^{14}$ The generated excited species could be used for the oxidative alkynylation of several functional groups and alkenes. A key advantage of this approach is the simplicity of the procedure, requiring only the irradiation of a mixture of substrates and EBX reagents without the need for fine-tuned photocatalysts and additives. We wondered therefore if this approach would be also successful in the case of the oxyalkynylation of the $\mathrm{C}-\mathrm{C}$ bond of aryl cyclopropanes. 
Although the direct light-mediated oxidation of arylcyclopropanes has been reported with nitrogen-based and chloride radicals, ${ }^{15}$ alkynylation could not be achieved so far in absence of a photocatalyst.

Herein, we report the first ring-opening oxyalkynylation of aryl cyclopropanes through the direct photoexcitation of EBX reagents (Scheme 1D). The 1,3-oxyalkynylation products were obtained with full regioselectivity, in yields comparable to those of photocatalytic methods. The same conditions were also used for the 1,3-oxyalkynylation of aminocyclopropanes and the 1,2oxyalkynylation of styrenes. In addition, the reaction outcome could be changed from $\mathrm{C}-\mathrm{C}$ to $\mathrm{C}-\mathrm{H}$ alkynylation in dependence of the aryl group on the cyclopropane.

\section{Results and discussion}

To start our studies, we choose para-methoxybenzene substituted cyclopropane $\mathbf{1 a}$, as it can be oxidized at a relatively low potential $\left(E_{1 / 2}=+1.35 \mathrm{~V}\right) .{ }^{15 b}$ As we had estimated the oxidation potential of photoexcited Ph-EBX* $\left(2 \mathrm{a}^{*}\right)$ to be +1.8 $\mathrm{V},{ }^{14}$ the generation of a radical cation should be possible. Indeed, efficient oxyalkynylation to give 3a was observed (Table 1). The best results were obtained using chloroform as solvent and $\mathbf{2 . 5}$ equivalents of $\mathbf{2 a}$. Under these conditions, 3a was isolated in $68 \%$ yield. The only observed side product was double addition of 2 -iodobenzoate in $10 \%$ yield, probably resulting from over-oxidation of the benzylic radical to the cation. To obtain reproducible results, thorough degassing of the reaction mixture and purifying $\mathrm{Ph}-\mathrm{EBX}$ (2a) by recrystallization were required (See Supporting Information for details). Product 3a was also obtained in other chlorinated solvents, but only in moderate yields (entries 2-3). Only very low yields were observed in other solvents (entry 4). Irradiation at $467 \mathrm{~nm}$ was less efficient (entry 5). No product was obtained when using a blue LED strip (entry 6). This confirmed that strong irradiation is needed to activate directly aryl EBX reagents. During completion of our work, Zuo and Studer indeed reported that a photocatalyst and $\mathrm{BI}-\mathrm{OAc}$ as additive are needed with blue LED strips to obtain $3 a$ in $67 \%$ isolated yield. ${ }^{13} \mathrm{~A}$ lower yield was obtained with two equivalents $2 a$, and using three equivalents did not improve the yield (entries 7 and 8). This is in agreement with what we observed in our previous work, ${ }^{14}$ indicating that one equivalent of $\mathbf{2 a}$ is probably acting as oxidant, and a second one as alkynylation reagent. In contrast to Zuo and Studer's work, no additive was need in the reaction and adding $50 \%$ of BI-OAC gave no improvement (entry 9 ). Finally, no product was obtained when heating the reaction mixture at $50{ }^{\circ} \mathrm{C}$ in the dark (entry 10$)$.

\begin{tabular}{|c|c|c|c|}
\hline $\mathrm{MeO}^{\prime}$ & $\begin{array}{c}\text { Ph-EBX (2a) } \\
\frac{2.5 \text { equiv }}{\text { Kessil } 440 \mathrm{~nm}, 80 \mathrm{~W}} \\
\mathrm{CHCl}_{3}\end{array}$ & $\overbrace{\mathrm{OMe}}^{1}$ & \\
\hline Entry & Deviation from conditions & $\begin{array}{c}\text { Conversion } \\
(\%)^{\mathrm{a}}\end{array}$ & $\begin{array}{l}\text { Yield } \\
(\%)^{\mathrm{a}}\end{array}$ \\
\hline 1 & none & $>95$ & $72(68)$ \\
\hline 2 & In $\mathrm{CH}_{2} \mathrm{Cl}_{2}$ & 94 & 54 \\
\hline 3 & In DCE & 61 & 20 \\
\hline 4 & $\begin{array}{c}\text { In } \mathrm{MeOH}, \mathrm{DMF}, \mathrm{CH}_{3} \mathrm{CN}, \mathrm{THF} \\
\text { EtOAC, DMSO, } \mathrm{PhCl}\end{array}$ & $0-74$ & $<14$ \\
\hline 5 & Kessil lamp 467 nm & 43 & 28 \\
\hline 6 & blue LED strip & 6 & $<5$ \\
\hline 7 & 2 equiv $\mathrm{Ph}-\mathrm{EBX}(\mathbf{2 a})$ & 88 & 58 \\
\hline 8 & 3 equiv $\mathrm{Ph}-\mathrm{EBX}(\mathbf{2 a})$ & $>95$ & 73 \\
\hline 9 & 0.5 equiv $\mathrm{Bl}-\mathrm{OAc}, 2$ equiv $2 \mathrm{a}$ & 85 & 52 \\
\hline 10 & In the dark at $50^{\circ} \mathrm{C}$ & 4 & $<5$ \\
\hline
\end{tabular}

Reaction Conditions: $0.2 \mathrm{mmol} 1 \mathrm{1a}$ (1 equiv), $0.5 \mathrm{mmol} 2$ ( 2.5 equiv), two Kessil lamps (440 nm, $2 \times 40 \mathrm{~W}$ ), in $2 \mathrm{~mL} \mathrm{CHCl} 3 .{ }^{a} \mathrm{H}$ NMR Yield and conversion were determined with $\mathrm{CH}_{2} \mathrm{Br}_{2}$ as an internal standard. Isolated yield after chromatography is given in brackets.

With optimized conditions in hand, we studied first the scope of arylcyclopropanes (Scheme 2A). As expected, electron-rich substituents were required to promote the reaction: oxyalkynylation products 3a-c bearing a methoxy or an ethoxy substituent were obtained in $51-68 \%$ yield, whereas a tert-butyl substituent gave $\mathbf{3 d}$ in only $15 \%$ yield and no product was obtained for an unsubstituted benzene ring (3e). For $\mathbf{3 a}$ and $\mathbf{3 b}$, the yields obtained were comparable or slightly superior to the photocatalytic method developed by Zuo and Studer. ${ }^{13}$ However, the photocatalyst approach is superior for less electron-rich substrates not accessible via direct photoexcitation of EBXs: Products $\mathbf{3 d}$ and $\mathbf{3 e}$ where obtained in $52 \%$ and $40 \%$ respectively using an acridinium dye as photocatalyst. A methyl group in ortho position was well tolerated to give product 3f. However, no product $\mathbf{3 g}$ was obtained with two ortho methyl groups. Surprisingly, C-H alkynylation product 4 a was isolated in $85 \%$ yield instead. In presence of a methoxy group, an electron-deficient fluoro substituent was tolerated to give product $3 \mathrm{~h}$ in $46 \%$ yield. Starting from $\beta$-substituted cyclopropanes, products $\mathbf{3 i}$ and $\mathbf{3 j}$ were obtained in $70 \%$ and $54 \%$ yield with selective attack of the iodobenzoate at the most encumbered position.

We then examined the scope of EBX reagents, considering that only aryl-substituted EBXs are photoactive (Scheme 2B). ${ }^{14} \mathrm{~A}$ tolyl-substituted EBX gave $\mathbf{3 k}$ in $45 \%$ yield. Introduction of a para-trifluoromethyl or a chloro group on the aryl ring of the alkyne led to $\mathbf{3 I}$ and $\mathbf{3 m}$ in $63 \%$ yield. Fluoro substituents were also tolerated, but gave only moderate yields of $\mathbf{3 n}$ and $\mathbf{3 0}$. These results contrasted with our previous work were only Phand tolyl-EBX gave useful yields of products. ${ }^{14}$ 


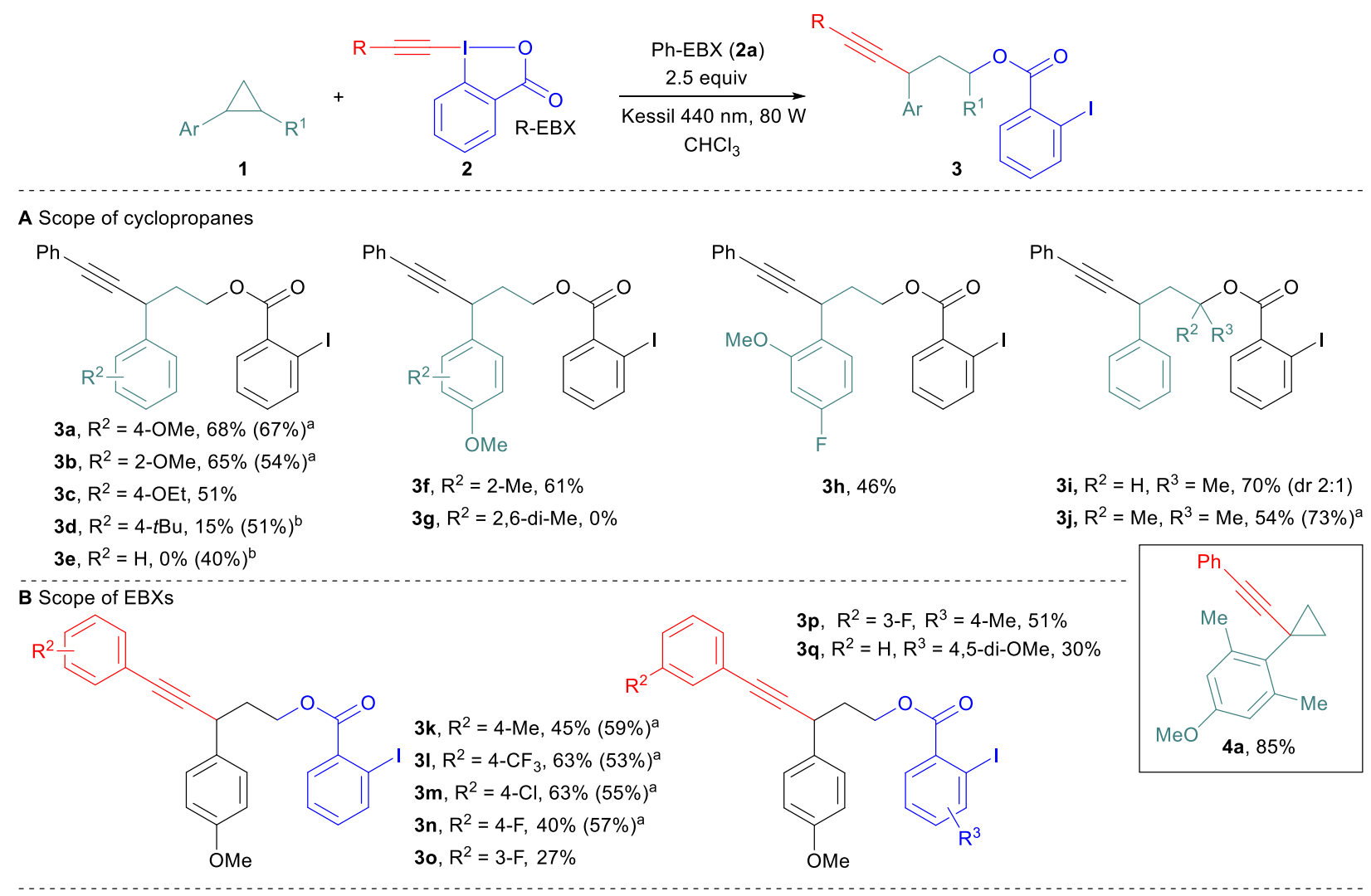

Scheme 2 Scope of the oxyalkynylation of arylcyclopropanes. Reaction Conditions: $0.2 \mathrm{mmol}$ 1a (1 equiv), $0.5 \mathrm{mmol} 2$ ( 2.5 equiv), two Kessil lamps ( $440 \mathrm{~nm}, 2 \times 40 \mathrm{~W}$ ), in $2 \mathrm{~mL}$ $\mathrm{CHCl}_{3}$. Isolated yield after column chromatograpy is given. ${ }^{\text {a }}$ Yield reported in Ref. 13 using 4-CzIPN as photocatalyst and BI-OAc as additive. ${ }^{\text {bYield }}$ using Ph-Acr-MesBF 4 as photocatalyst.

Finally, an advantage of EBXs is that the properties can be finely tuned by modification of the 2-iodobenzoic acid core of the reagent. For example the yield of transfer of the 3-F-benzene substituted alkyne could be increased from 27 to $51 \%$ by introducing a methyl group para to the carboxylic acid (product 3p). A dimethoxy-substituted reagent could also be used to give $3 q$ in $30 \%$ yield.

Our main goal was the oxyalkynylation of the $\mathrm{C}-\mathrm{C}$ bond of arylcyclopropanes. However, the same conditions can be also applied to the oxyalkynylation of aminocyclopropane $\mathbf{5 a}$ giving products $\mathbf{6 a}$ and $\mathbf{6 b}$ in $53 \%$ and $51 \%$ yield (Scheme $3 \mathrm{~A}$ ). As reported by Chen for the photocatalytic reaction, ${ }^{12}$ a complete inversion of the regioselectivity can be observed in this case. This is probably due to the lower stability of the radical cation, leading to ring-opening prior to attack of the nucleophile. The oxyalkynylation is not limited to $\sigma-\mathrm{C}-\mathrm{C}$ bonds. Indeed, electronrich styrene derivatives $7 \mathbf{7 a - c}$ could be converted to products $\mathbf{8 a -}$ c in $44-56 \%$ yield with complete regioselectivity via 1,2oxyalkynylation of the $\pi$ bond (Scheme $3 \mathrm{~B}$ ). In this case, the same regioselectivity is observed as for enamides. ${ }^{6 b}$

Finally, we turned back to the intriguing $\mathrm{C}-\mathrm{H}$ alkynylation observed in the case of arylcyclopropane 1g. In fact, 1,1-arylalkynyl cyclopropanes are useful building blocks in synthetic and medicinal chemistry. ${ }^{16}$ They have never been accessed via $\mathrm{C}-\mathrm{H}$ alkynylation, which has been realized mostly on unsubstituted positions using directing group mediated transition metal catalysis. ${ }^{17}$ We were pleased to see that the Ph-EBX (2a) mediated alkynylation of $\mathbf{1 g}$ was surprisingly efficient, with $83 \%$ product $4 \mathrm{a}$ isolated after $7 \mathrm{~h}$ of irradiation with only 1.5 equivalents of $\mathbf{2 a}$ (Scheme $3 \mathrm{C}$ ). The reaction was easily scalable and $4 \mathrm{a}$ was obtained in $92 \%$ on a $2 \mathrm{mmol}$ scale. The transformation was also successful with functionalized EBX reagents. Alkyl substituents in para position on the benzene ring gave products $\mathbf{4 b}$ and $\mathbf{4} \mathbf{c}$ in $65 \%$ and $40 \%$ yield. A trifluoromethyl group and halogens were well tolerated at this position, giving products $4 \mathbf{d}-\mathbf{g}$ in $70-81 \%$ yield. Finally, products $4 \mathbf{h}$ and $4 \mathbf{i}$, bearing a meta fluoro and an ortho bromo group respectively, were obtained in $61 \%$ and $54 \%$ yield.

Based on our experimental results and our previous studies, ${ }^{14} \mathrm{a}$ highly speculative reaction mechanism can be proposed (Scheme 4A). Direct light activation of Ph-EBX (2a) would lead to the highly oxidizing species $2 a^{*}$. Single electron transfer from arylcyclopropane $\mathbf{1}$ would give then radical anion I and radical cation II. In a previous work, we showed by computation that I was relatively stable to monomolecular decomposition. ${ }^{18}$ The major side product observed in the photoactivation of $\mathbf{2 a}$ is diyne 9, probably formed in either of two bimolecular pathway: Reaction with another molecule of I to give 9 and 2 equivalents of 2-iodobenzoate (10), or with $\mathbf{2 a}$ to give $\mathbf{9}, \mathbf{1 0}$ and radical III. 
A 1,3-Oxyalkynylation of aminocyclopropanes

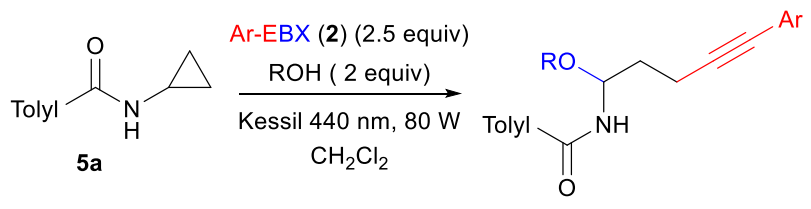

6a, $\mathrm{R}=\mathrm{Me}, \mathrm{Ar}=4-\mathrm{CIPh}, 53 \%$

B 1,2-Oxyalkynylation of styrenes

6b, $\mathrm{R}=\mathrm{Bu}, \mathrm{Ar}=4-\mathrm{FPh}, 51 \%$

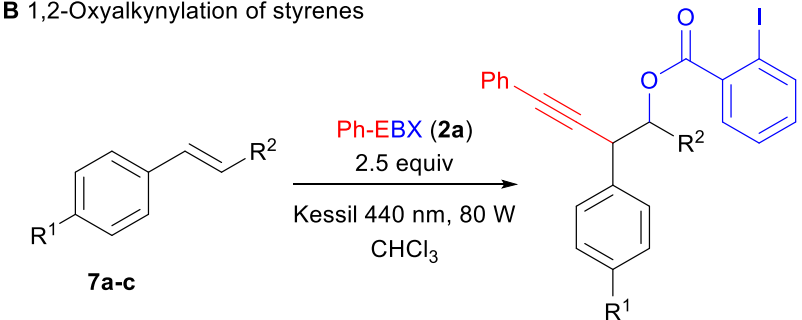

8a, $R^{1}=O M e, R^{2}=M e, 56 \%(d r 2: 1)$

8b, $R^{1}=O M e, R^{2}=H, 44 \%$

$8 c, R^{1}=t B u, R^{2}=H, 48 \%$

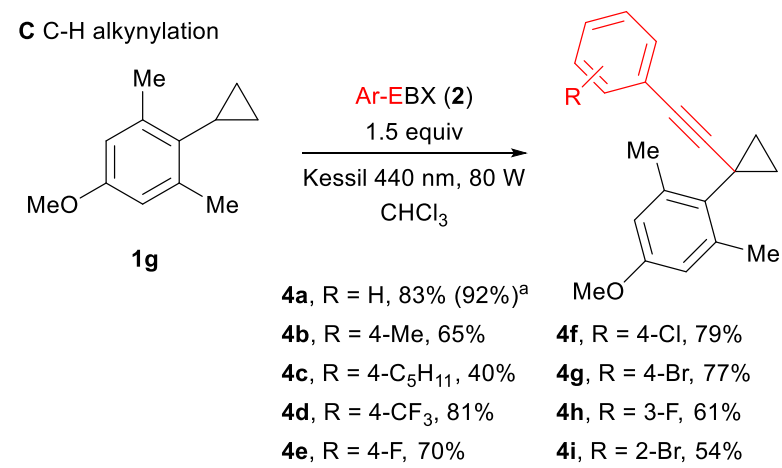

Scheme 3 1,3-Oxyalkynylation of aminocyclopropanes (A), 1,2-oxyalkynylation of styrene derivatives (B) and C-H alkynylation of arylcyclopropanes (C). Isolated yields on $0.2 \mathrm{mmol}$ scale are given, see Supporting Information for detailed experimental procedures. alsolated yield on a $2 \mathrm{mmol}$ scale.

From radical cation II, two pathways can be considered. Ring opening with benzoate $\mathbf{1 0}$ to give the more stable radical IV, followed by reaction with $\mathbf{2 a}$ (or I) would lead to the oxyalkynylation product $\mathbf{3}$ (pathway a). Deprotonation with benzoate $\mathbf{1 0}$ would give radical $\mathbf{V}$, which would be then alkynylated by either $\mathbf{2 a}$ or $\mathbf{I}$ resulting in the formation of $\mathbf{4}$ (pathway b). In general, we would favour alkynylation with $\mathbf{2 a}$, as it would be present in higher concentration, but an involvement of I cannot be excluded, especially in the case of C$\mathrm{H}$ alkynylation, which is surprisingly efficient. For $\mathrm{C}-\mathrm{H}$ alkynylation, a radical chain mechanism involving radical III should also be considered. In fact, $\mathrm{H}$ abstraction from $\mathbf{1}$ by III would give directly radical $\mathbf{V}$. However, we think that this mechanism may be less probable, as no alkynylation was observed with arylcyclopropanes lacking the methoxy group such as $\mathbf{1 k}$, showing that oxidation of the substrate is probably needed for the reaction to occur. Furthermore, direct HAT on cyclopropanes is generally difficult, due to the stronger $\mathrm{C}-\mathrm{H}$ bond/lower stability of the radical. ${ }^{19}$

A striking result of our studies was the complete switch of chemoselectivity when introducing a second ortho methyl group on the arene ring. A tentative explanation may be found in the conformation analysis of the cyclopropane (Scheme 4B).
It is well-known that aryl cyclopropanes favour a bisected conformation to enable overlap between the $\pi$-Walsh orbitals and the $\pi^{*}$ of the benzene ring. ${ }^{20}$ Another effect of this interaction is also the weakening of the $\mathrm{C}-\mathrm{C}$ bond and favour ring-opening. With one ortho group, a low energy bisected conformer is still available. However, when a second ortho group is present, strong steric interactions with the cyclopropane cannot be avoided anymore. Therefore, the usually less favoured perpendicular conformation becomes lower in energy. In this conformation, there is nearly no effect of the benzene ring on the strength of the $\mathrm{C}-\mathrm{C}$ bonds. In contrast, one may envision a weakening interaction between the $\pi$ system of the benzene and the $\sigma^{*}$ orbital of the $\mathrm{C}-\mathrm{H}$ bond, favouring deprotonation/ $\mathrm{H}$ abstraction. Of course, care has to be taken with this simple conformational analysis of the starting material, and future studies will focus on computations involving radical cation II and the transition states of the proposed pathways $\mathbf{a}$ and $\mathbf{b}$.

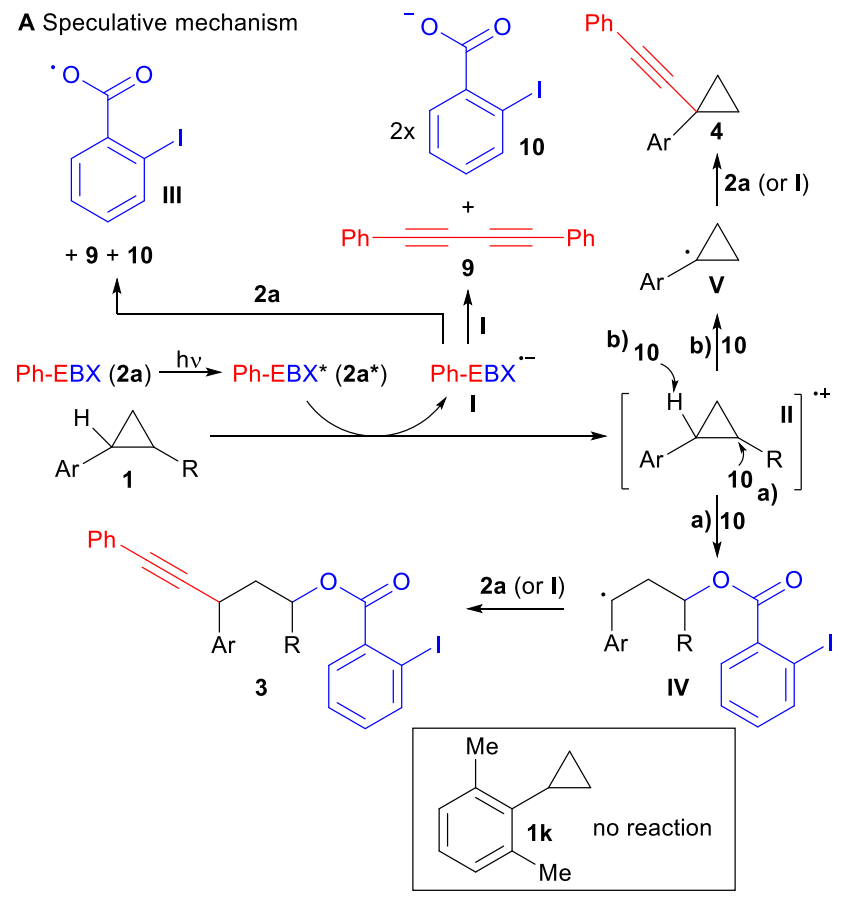

B Conformational analysis
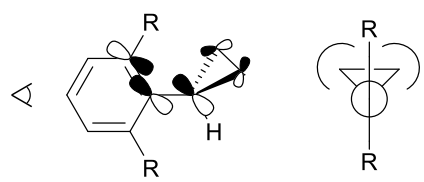

bisected conformation: $\mathrm{C}-\mathrm{C}$ bond weakened
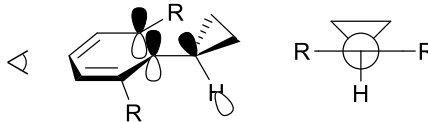

perpendicular conformation

$\mathrm{C}-\mathrm{H}$ bond weakened

Scheme 4 Speculative mechanism for the $\mathrm{C}-\mathrm{C}$ oxyalkynylation and the $\mathrm{C}-\mathrm{H}$ alkynylation reactions (A) and conformational analysis of arylcyclopropanes (B).

\section{Conclusions}

In summary, we have reported a light-mediated oxyalkynylation of the $\mathrm{C}-\mathrm{C}$ bond of arylcyclopropanes via the direct photoactivation of aryl-EBX reagents with visible light. In contrast to previous works, neither photocatalysts nor additive 
were needed. In addition, we discovered a complete switch of the reaction outcome from $\mathrm{C}-\mathrm{C}$ to $\mathrm{C}-\mathrm{H}$ alkynylation when using aryl cyclopropanes bearing two ortho substituents on the benzene ring. We tentatively attributed this effect to the conformational constrains induced by the aryl ring, and we think this result will pave the way for the development of new selective transformations of cyclopropanes.

\section{Author Contributions}

T.V.T. $N$ planned the research and performed all the experiments described, prepared the material for the redaction of the manuscript and the supporting information. J. W. supervised the research, participated to the redaction and finalization of the manuscript, as well as proof-read the supporting information.

\section{Conflicts of interest}

There are no conflicts to declare.

\section{Acknowledgements}

This work is supported by the Swiss National Science Foundation (SNSF, grant no. 200020_182798). We thank Dr. Stefano Nicolai for proof-reading this manuscript.

\section{Notes and references}

1. Yoshimura, A.; Zhdankin, V. V. Chem. Rev. 2016, 116, 3328.

2. Le Vaillant, F.; Waser, J. Chem. Sci. 2019, 10, 8909.

3. Diederich, F.; Stang, P. J.; Tykwinski, R. R., Acetylene Chemistry: Chemistry, Biology and Material Science. Wiley-VCH: 2005.

4. (a) Zhou, Q.; Guo, W.; Ding, W.; Wu, X.; Chen, X.; Lu, L.; Xiao, W. Angew. Chem., Int. Ed. 2015, 54, 11196. (b) Le Vaillant, F.; Courant, T.; Waser, J. Angew. Chem., Int. Ed. 2015, 54, 11200. (c) Garreau, M.; Le Vaillant, F.; Waser, J. Angew. Chem., Int. Ed. 2019, 58, 8182.

5. Li, M.; Li, J.; He, H.; Dai, H.; Xie, J. J. Org. Chem. 2021, 86, 12386.

6. (a) Jiang, H.; Studer, A. Chem. Eur. J. 2019, 25, 516. (b) Amos,

S. G. E.; Nicolai, S.; Waser, J. Chem. Sci. 2020, 11, 11274.

7. (a) Paul, S.; Guin, J. Green Chem. 2017, 19, 2530-2534. (b) Voutyritsa, E.; Garreau, M.; Kokotou, M. G.; Triandafillidi, I.; Waser, J.; Kokotos, C. G. Chem. Eur. J. 2020, 26, 14453.

8. Schneider, T. F.; Kaschel, J.; Werz, D. B. Angew. Chem., Int. Ed. 2014, 53, 5504.

9. Selected examples: (a) Ilchenko, N. O.; Hedberg, M.; Szabó, K. J. Chem. Sci. 2017, 8, 1056. (b) Banik, S. M.; Mennie, K. M.; Jacobsen, E. N. J. Am. Chem. Soc. 2017, 139, 9152. (c) Gieuw, M. H.; Ke, Z. H.; Yeung, Y. Y. Angew. Chem., Int. Ed. 2018, 57, 3782 (d) Yang, S.; Wang, L.; Zhang, H.; Liu, C.; Zhang, L.; Wang, X.; Zhang, G.; Li, Y.; Zhang, Q. ACS Catal. 2019, 9, 716. (e) Wang, L. H.; Wang, X. M.; Zhang, G.; Yang, S. B.; Li, Y.; Zhang, Q. Org.
Chem. Fron. 2019, 6, 2934. (f) Zhang, H.; Xiao, H.; Jiang, F.; Fang, Y.; Zhu, L.; Li, C. Org. Lett. 2021, 23, 2268.

10. Selected examples: (a) Lu, Z.; Parrish, J. D.; Yoon, T. P. Tetrahedron 2014, 70, 4270. (b) Feng, L.; Yan, H.; Yang, C.; Chen, D.; Xia, W. J. Org. Chem 2016, 81, 7008. (c) Ge, L.; Wang, D.; Xing, R.; Ma, D.; Walsh, P. J.; Feng, C. Nat. Commun. 2019, 10, 4367. (d) Liu, H.; Li, Y.; Wang, D.-X.; Sun, M.-M.; Feng, C. Org. Lett. 2020, 22, 8681. (e) Zuo, Z.; Daniliuc, C. G.; Studer, A. Angew. Chem., Int. Ed. 2021, 60, 25252.

11. (a) Wang, S.; Guo, L. N.; Wang, H.; Duan, X. H. Org. Lett. 2015, 17, 4798. (b) Murali, R.; Rao, N. N.; Cha, J. K. Org. Lett. 2015, 17, 3854. (c) Jia, K.; Zhang, F.; Huang, H.; Chen, Y. J. Am. Chem. Soc. 2016, 138, 1514. (d) Wang, C. Y.; Song, R. J.; Xie, Y. X.; Li, J. H. Synthesis 2016, 48, 223. (e) Cheng, B. Q.; Zhang, S. X.; Cui, Y. Y.; Chu, X. Q.; Rao, W. D.; Xu, H. Y.; Han, G. Z.; Shen, Z. L. Org. Lett. 2020, 22, 5456-5461.

12 Liu, Z.; Wu, S.; Chen, Y. ACS. Catal. 2021, 11, 10565.

13. Zuo, Z.; Studer, A. Org. Lett. 2022, DOI: 10.1021/acs.orglett.1c04319.

14. Amos, S. G. E.; Cavalli, D.; Le Vaillant, F.; Waser, J. Angew. Chem., Int. Ed. 2021, 60, 23827.

15. (a) Pitts, C. R.; Ling, B.; Snyder, J. A.; Bragg, A. E.; Lectka, T. J. Am. Chem. Soc. 2016, 138, 6598. (b) Petzold, D.; Singh, P.; Almqvist, F.; König, B. Angew. Chem., Int. Ed. 2019, 58, 8577. 16. Selected examples: (a) Ma, S.; He, Q. Tetrahedron 2006, 62, 2769. (b) Zhang, X.-M.; Tu, Y.-Q.; Jiang, Y.-J.; Zhang, Y.-Q.; Fan, C.-A.; Zhang, F.-M. Chem. Commun. 2009, 4726. (c) Walsh, S. P.; Severino, A.; Zhou, C.; He, J.; Liang, G.-B.; Tan, C. P.; Cao, J.; Eiermann, G. J.; Xu, L.; Salituro, G.; Howard, A. D.; Mills, S. G.; Yang, L. Bioorg. Med. Chem. Lett. 2011, 21, 3390. Review on the synthesis of alkynyl cyclopropanes: (d) Gvozdev, V. D.; Shavrin, K. N.; Egorov, M. P.; Nefedov, O. M. Russ. Chem. Bull. 2021, 70, 2051.

17. Selected examples: (a) Kim, J.; Sim, M.; Kim, N.; Hong, S. Chem. Sci. 2015, 6, 3611. (b) Jerhaoui, S.; Djukic, J.-P.; WencelDelord, J.; Colobert, F. ACS Catal. 2019, 9, 2532.

18 Le Vaillant, F.; Wodrich, M. D.; Waser, J. Chem. Sci. 2017, 8, 1790.

19. (a) Tian, Z.; Fattahi, A.; Lis, L.; Kass, S. R. J. Am. Chem. Soc. 2006, 128, 17087. (b) Wang, D.; Mück-Lichtenfeld, C.; Studer, A. J. Am. Chem. Soc. 2019, 141, 14126.

20. (a) Drumright, R. E.; Mas, R. H.; Merola, J. S.; Tanko, J. M. J. Org. Chem 1990, 55, 4098. (b) Shen, Q.; Wells, C.; Traetteberg, M.; Bohn, R. K.; Willis, A.; Knee, J. J. Org. Chem 2001, 66, 5840. (c) Tsuji, M. J. Org. Chem 2004, 69, 4063. (d) Craig, A. J.; Hawkins, B. C. Synthesis 2020, 52, 27. 


\section{SUPPORTING INFORMATION}

\section{Contents}

General Methods

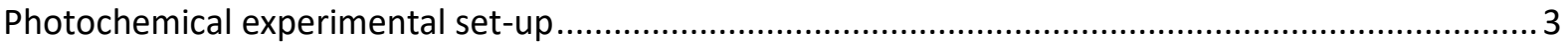

Synthesis of aryl cyclopropanes, aminocyclopropanes. ......................................................

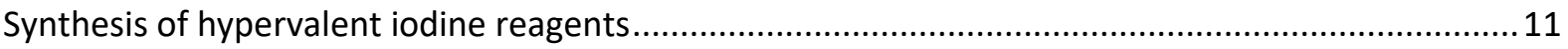

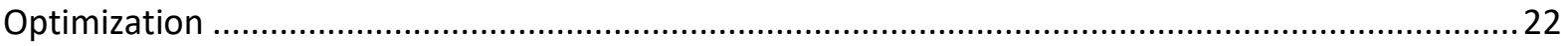

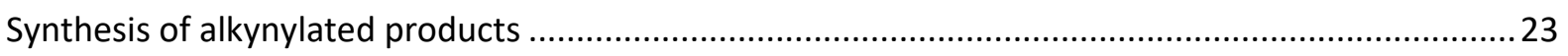

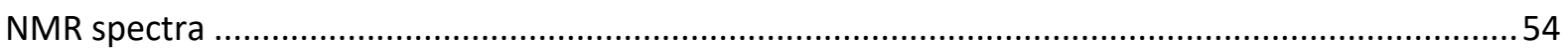

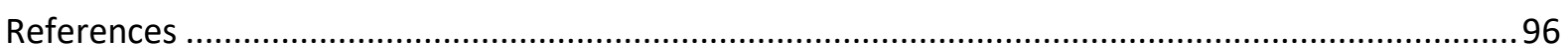




\section{General Methods}

For quantitative flash chromatography, distilled technical grade solvents were used. $\mathrm{THF} \mathrm{Et}_{2} \mathrm{O}$, toluene, hexane and $\mathrm{CH}_{2} \mathrm{Cl}_{2}$ were dried by passage over activated alumina under nitrogen atmosphere $\left(\mathrm{H}_{2} \mathrm{O}\right.$ content $<7 \mathrm{ppm}, \mathrm{Karl}-\mathrm{Fischer}$ titration). All chemicals were purchased and used as received unless stated otherwise. Chromatographic purification was performed as flash chromatography using Macherey-Nagel silica 40-63, $60 \AA$, using the solvents indicated as eluent with 0.1-0.5 bar pressure. TLC was performed on Merck silica gel 60 F254 TLC plastic or aluminium plates and visualized with UV light, permanganate stain. Melting points were measured on a calibrated Büchi B-540 melting point apparatus using open glass capillaries. ${ }^{1} \mathrm{H}-\mathrm{NMR}$ spectra were recorded at room temperature on a Brucker DPX-400 $400 \mathrm{MHz}$ spectrometer in $\mathrm{CDCl}_{3}$, Acetone- $d_{6}, \mathrm{CD}_{3} \mathrm{CN}$ or $\mathrm{CD}_{3} \mathrm{OD}$, all signals are reported in ppm with the internal chloroform signal at $7.26 \mathrm{ppm}$, the internal acetone signal at 2.09 $\mathrm{ppm}$, the internal acetonitrile signal at $1.94 \mathrm{ppm}$ and the internal methanol signal at $3.34 \mathrm{ppm}$ as standard. The data is being reported as $(\mathrm{s}=$ singlet, $\mathrm{d}=$ doublet, $\mathrm{t}=$ triplet, $\mathrm{q}=$ quadruplet, $\mathrm{p}=$ quintet, $\mathrm{m}=$ multiplet or unresolved, $\mathrm{br}=$ broad signal, integration, coupling constant(s) in $\mathrm{Hz}$, interpretation).

${ }^{13} \mathrm{C}$-NMR spectra were recorded with $1 \mathrm{H}$-decoupling on a Brucker DPX-400 $101 \mathrm{MHz}$ spectrometer in $\mathrm{CDCl}_{3}$, Acetone- $d_{6}, \mathrm{CD}_{3} \mathrm{CN}$ or $\mathrm{CD}_{3} \mathrm{OD}$, all signals are reported in ppm with the internal chloroform signal at $77.0 \mathrm{ppm}$, Acetone- $d_{6}$ signal at $29.8 \mathrm{ppm}, \mathrm{CD}_{3} \mathrm{CN}$ signal at $1.3 \mathrm{ppm}$ or $\mathrm{CD}_{3} \mathrm{OD}$ signal at $49.0 \mathrm{ppm}$ as standard. Infrared spectra were recorded on a JASCO FT-IR B4100 or a Bruker Alpha-P spectrophotometer with an ATR device and a ZnSe prism and are reported as $\mathrm{cm}-1(\mathrm{w}=$ weak, $\mathrm{m}=$ medium, $s=$ strong). High resolution mass spectrometric measurements were performed by the mass spectrometry service of ISIC at the EPFL on a MICROMASS (ESI) Q-TOF Ultima API. HPLC measurements were done on a Agilent 1260 Infinity autosampler using a CHIRALPAK IA, IB, IC or IF column from DAICEL Chemical. The specific solvents and concentrations (in $\mathrm{g} / 100 \mathrm{~mL}$ ) are indicated.

All photocatalyzed reactions were carried out in oven dried glassware and under inert atmosphere (freeze pump thaw solvent stored on molecular sieves and under argon for maximum one week) unless specified otherwise. They were placed on a stirring plate with Kessil lamps (440 nm, 40 W) irradiating from both sides (the hood was free and coated with aluminum foil for personal protection). The distance between the Kessil lamps and the vials was approximatively $10 \mathrm{~cm}$. Long irradiation resulted in temperature increasing up to $50^{\circ} \mathrm{C}$ during overnight reactions unless a fan was used in which case the temperature raised to $30-35^{\circ} \mathrm{C}$. 
Photochemical experimental set-up

$0.2 \mathrm{mmol}$ scale reactions (both set-up can be used without affecting the yields)
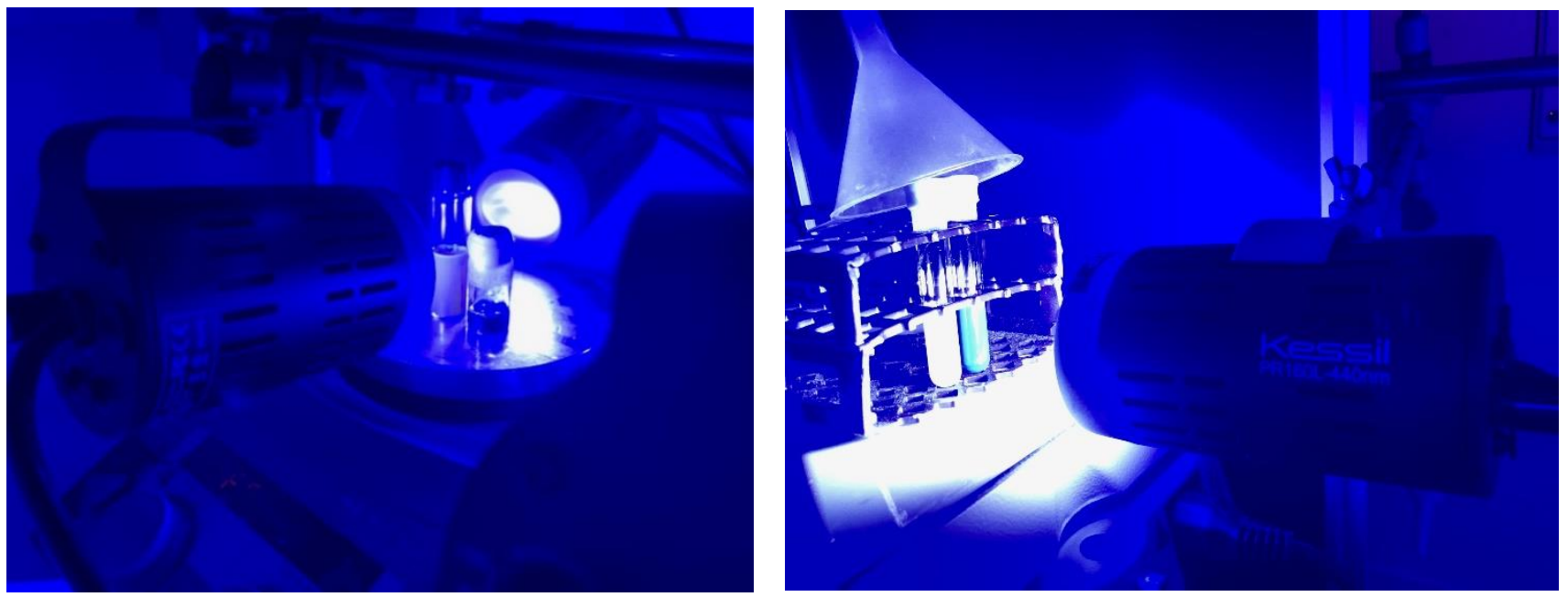

$2 \mathrm{mmol}$ scale reactions

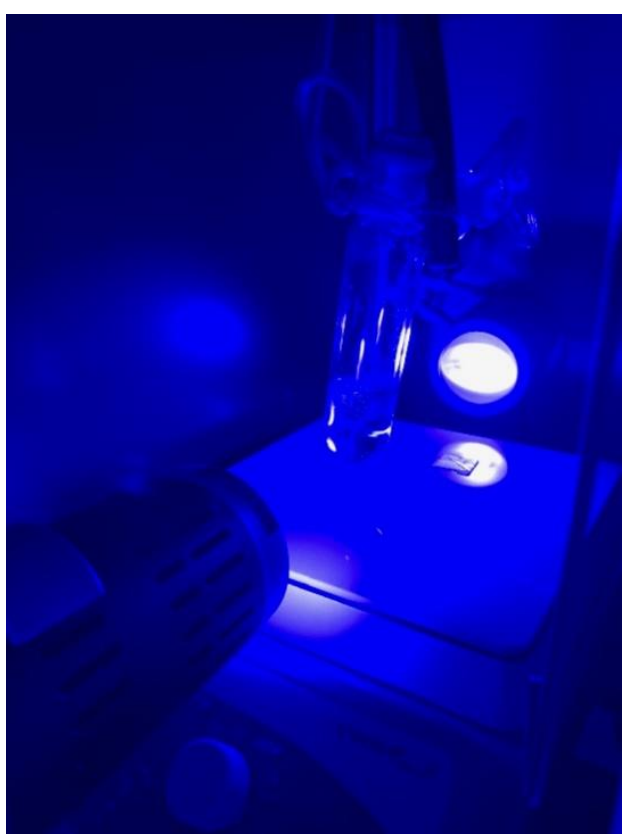


Synthesis of aryl cyclopropanes, aminocyclopropanes.

- Compound $1 \mathrm{e}, \mathbf{7 a}, \mathbf{7 b}, \mathbf{7 c}$ are commercially available and were used directly without further purification

General procedure A: Synthesis of aryl cyclopropanes

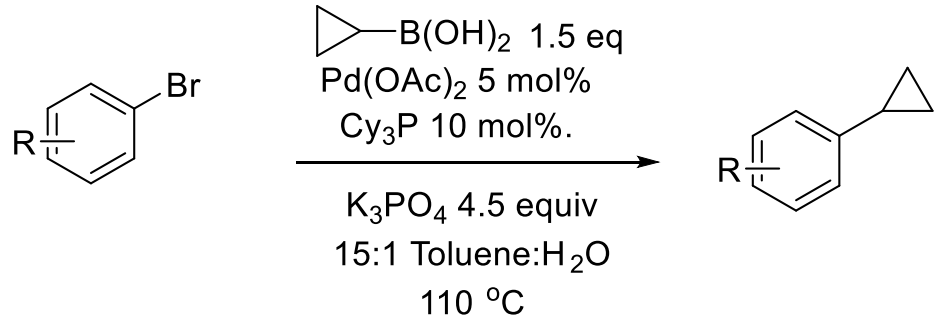

To a solution of aryl bromide ( $5.00 \mathrm{mmol}, 1.00$ equiv) in 15:1 toluene:water ( $32 \mathrm{~mL}$ ) was added potassium phosphate tribasic potassium (4.78 g, $22.5 \mathrm{mmol}, 4.50$ equiv), cyclopropylboronic acid (644 mg, $7.50 \mathrm{mmol}, 1.50$ equiv), $0.5 \mathrm{ml}$ Tricyclohexylphosphine (1M solution in toluene) and palladium(II) diacetate $(56.1 \mathrm{mg}, 250 \mu \mathrm{mol}, 0.0500$ equiv). The resulting mixture was heated to $110^{\circ} \mathrm{C}$. After 12 hours, the reaction mixture was cooled to room temperature, diluted with DCM $(100 \mathrm{~mL})$ and washed with water $(100 \mathrm{~mL})$. The aqueous layer was extracted with DCM $(3 \times 100 \mathrm{~mL})$. The combined organic layers were washed with brine $(50 \mathrm{~mL})$, dried over $\mathrm{Na}_{2} \mathrm{SO}_{4}$, filtered and concentrated under reduced pressure. The crude mixture was purified by column chromatography on Biotage (Büchi flashpure cartridge $40 \mathrm{~g}$, gradient of pentane: ethyl acetate from 99:1 to 95:5). to obtain the product.

\section{1-Cyclopropyl-4-methoxybenzene (1a)}

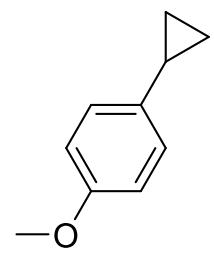

Following the general procedure A, starting from 1-bromo-4-methoxybenzene $(935 \mathrm{mg}, 5.00$ mmol, 1.00 equiv), 1-cyclopropyl-4-methoxybenzene 1a (580 mg, $3.91 \mathrm{mmol}, 78 \%$ yield) was obtained as a colorless liquid. ${ }^{1} \mathrm{H}$ NMR $\left(400 \mathrm{MHz}, \mathrm{CDCl}_{3}\right) \delta 7.09-6.97(\mathrm{~m}, 2 \mathrm{H}, \mathrm{ArH}), 6.90-$ $6.77(\mathrm{~m}, 2 \mathrm{H}, \mathrm{ArH}), 3.78(\mathrm{~s}, 3 \mathrm{H}, \mathrm{OCH})_{3}, 1.86\left(\mathrm{~m}, 1 \mathrm{H}, \mathrm{CHCH}_{2}\right), 0.98-0.84\left(\mathrm{~m}, 2 \mathrm{H}, \mathrm{CHCH}_{2}\right), 0.71-$ $0.57\left(\mathrm{~m}, 2 \mathrm{H}, \mathrm{CHCH}_{2}\right) .{ }^{13} \mathrm{C} \mathrm{NMR}\left(101 \mathrm{MHz}, \mathrm{CDCl}_{3}\right) \delta 157.7,136.0,127.0,113.9,55.4,14.7,8.6$. Consistent with reported data. ${ }^{1}$ 


\section{1-Cyclopropyl-2-methoxybenzene (1b)}

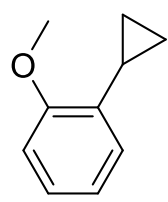

Following the general procedure A, starting from 1-bromo-2-methoxybenzene (935 mg, 5.00 mmol, 1.00 equiv), obtained 1-cyclopropyl-2-methoxybenzene (1b) (620 mg, 4.18 mmol, 84\% yield) as colorless oil. ${ }^{1} \mathbf{H}$ NMR (400 MHz, $\left.\mathbf{C D C l}_{3}\right) \delta 7.57$ - $7.50(\mathrm{~m}, 1 \mathrm{H}, \mathrm{ArH}), 7.37-7.17(\mathrm{~m}, 3 \mathrm{H}$, $\operatorname{ArH}), 4.26\left(\mathrm{~s}, 3 \mathrm{H}, \mathrm{OCH}_{3}\right), 2.60-2.53\left(\mathrm{~m}, 1 \mathrm{H}, \mathrm{CHCH}_{2}\right), 1.41-1.25\left(\mathrm{~m}, 2 \mathrm{H}, \mathrm{CHCH}_{2}\right), 1.13-1.00$ (m, 2H, $\left.\mathrm{CHCH}_{2}\right) .{ }^{13} \mathrm{C}$ NMR (101 MHz, $\left.\mathrm{CDCl}_{3}\right) \delta 158.4,132.1,126.4,124.9,120.7,110.3,55.7$, 9.4, 7.8. HRMS (APPI/LTQ-Orbitrap) m/z: [M] Calcd for $\mathrm{C}_{10} \mathrm{H}_{12} \mathrm{O}^{+}$148.0883; Found 148.0880. Consistent with reported data. ${ }^{1}$

\section{1-cyclopropyl-4-ethoxybenzene (1c)}
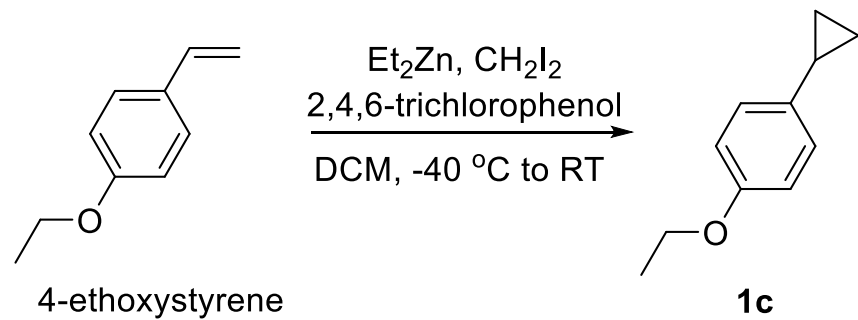

In a $150 \mathrm{~mL}$ oven-dried round-bottom flask with a stirring bar, was added 2,4,6trichlorophenol (1.18 g, $6.00 \mathrm{mmol}, 2.5$ equiv) under nitrogen atmosphere. DCM (60 mL, 0.1 $\mathrm{M})$ was added into the flask and the reaction mixture was cooled to $-40{ }^{\circ} \mathrm{C}$. $\mathrm{ZnEt}_{2}(1.0 \mathrm{M}, 6.0$ $\mathrm{mL}, 6.0 \mathrm{mmol}, 2.5$ equiv) was added slowly into the flask by syringe and the reaction mixture was stirred at this temperature for $15 \mathrm{~min}$. $\mathrm{CH}_{2} \mathrm{I}_{2}(2.6 \mathrm{~g}, 9.6 \mathrm{mmol}, 4.0$ equiv) was added slowly by syringe and the reaction mixture was stirred at this temperature for another $15 \mathrm{~min}$. Next, the corresponding solution of 4-ethoxystyrene ( $0.36 \mathrm{~g}, 2.4 \mathrm{mmol}, 1.0$ equiv) in DCM (10 mL) was added by syringe and the reaction mixture was allowed to warm to room temperature and stirred for $16 \mathrm{~h}$. After the reaction reached completion (as judged by ${ }^{1} \mathrm{H}-\mathrm{NMR}$ ), the reaction mixture was quenched with sat. $\mathrm{NH}_{4} \mathrm{Cl}(30 \mathrm{~mL})$ in 30 minutes and extracted with DCM $(100 \mathrm{~mL})$ for 3 times. The combined organic layers were washed with aq. $\mathrm{NaOH}(1.0$ $\mathrm{M}, 30 \mathrm{~mL})$ and brine $(20 \mathrm{~mL})$, dried over $\mathrm{Na}_{2} \mathrm{SO}_{4}(20 \mathrm{~g})$ and filtered. The mixture was concentrated under reduced pressure, the crude residue was purified by column chromatography (Pentane: EtOAc $=50: 1$ to $10: 1$ ) to afford the desired compound 1- 
cyclopropyl-4-ethoxybenzene (1c) $(243 \mathrm{mg}, 1.50 \mathrm{mmol} 63 \%)$ as colorless oil. $\mathbf{R f}=0.50\left(\mathrm{SiO}_{2}\right.$, 40:1 pentane:ethyl acetate. ${ }^{1} \mathrm{H}$ NMR $\left(400 \mathrm{MHz}, \mathrm{CDCl}_{3}\right) \delta 7.08-6.97(\mathrm{~m}, 2 \mathrm{H}, \mathrm{ArH}), 6.86-6.77$ (m, 2H, ArH), $4.01\left(\mathrm{q}, J=7.0 \mathrm{~Hz}, 2 \mathrm{H}, \mathrm{CH}_{2} \mathrm{O}\right), 1.86(\mathrm{tt}, J=8.5,5.1 \mathrm{~Hz}, 1 \mathrm{H}, \operatorname{ArCH}), 1.41(\mathrm{t}, J=7.0$ $\left.\mathrm{Hz}, 3 \mathrm{H}, \mathrm{CH}_{3}\right), 0.95-0.87\left(\mathrm{~m}, 2 \mathrm{H}, \mathrm{CHCH}_{2}\right), 0.63$ (dt, $\left.J=6.5,4.5 \mathrm{~Hz}, 2 \mathrm{H}, \mathrm{CHCH}_{2}\right) .{ }^{13} \mathrm{C}$ NMR (101 $\left.\mathrm{MHz}, \mathrm{CDCl}_{3}\right) \delta 157.0,135.8,126.9,114.5,63.6,15.0,14.7,8.6$. HRMS (APCI/QTOF) m/z: [M + $\mathrm{H}]^{+}$Calcd for $\mathrm{C}_{11} \mathrm{H}_{15} \mathrm{O}^{+}$163.1117; Found 163.1113.

1-Tert-butyl-4-cyclopropylbenzene (1d)

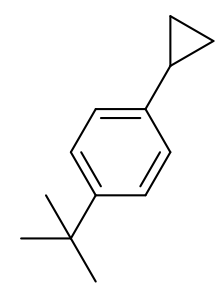

Following the general procedure A, starting from 1-bromo-4-tert-butylbenzene $(1.07 \mathrm{~g}, 5.00$ mmol, 1.00 equiv), 1-tert-butyl-4-cyclopropylbenzene (1d) $(710 \mathrm{mg}, 4.07 \mathrm{mmol}$, 81\% yield) was obtained as a colorless oil. ${ }^{1} \mathbf{H}$ NMR $\left(400 \mathrm{MHz}, \mathrm{CDCl}_{3}\right) \delta 7.33-7.27(\mathrm{~m}, 2 \mathrm{H}, \mathrm{ArH}), 7.07$ $7.00(\mathrm{~m}, 2 \mathrm{H}, \mathrm{ArH}), 1.88(\mathrm{tt}, J=8.4,5.1 \mathrm{~Hz}, 1 \mathrm{H}, \mathrm{ArCH}), 1.31\left(\mathrm{~s}, 9 \mathrm{H}, \mathrm{C}\left(\mathrm{CH}_{3}\right)_{3}\right), 0.97-0.89(\mathrm{~m}, 2 \mathrm{H}$, $\left.\mathrm{CHCH}_{2}\right), 0.74-0.64\left(\mathrm{~m}, 2 \mathrm{H}, \mathrm{CHCH}_{2}\right) .{ }^{13} \mathrm{C}$ NMR $\left(101 \mathrm{MHz}, \mathrm{CDCl}_{3}\right) \delta 148.4,141.0,125.5,125.3$, 34.5, 31.5, 15.0, 9.1. HRMS (APPI/LTQ-Orbitrap) m/z: [M] ${ }^{+}$Calcd for $\mathrm{C}_{13} \mathrm{H}_{18}{ }^{+}$174.1403; Found 174.1400. Consistent with reported data. ${ }^{2}$

\section{1-bromo-4-methoxy-2-methylbenzene (1f)}

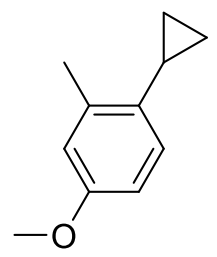

Following the general procedure A, starting from 1-bromo-4-methoxy-2-methylbenzene (1.01 g, 5.00 mmol, 1.00 equiv), obtained 1-cyclopropyl-4-methoxy-2-methylbenzene $1 \mathrm{f}$ (622 mg, $3.83 \mathrm{mmol}, 77 \%$ yield) as colorless oil. $\mathbf{R f}=0.44\left(\mathrm{SiO}_{2}, 40: 1\right.$ pentane:ethyl acetate) ${ }^{1} \mathbf{H} \mathbf{~ N M R}$ $\left(400 \mathrm{MHz}, \mathrm{CDCl}_{3}\right) \delta 6.94(\mathrm{~d}, J=8.4 \mathrm{~Hz}, 1 \mathrm{H}), 6.73(\mathrm{~d}, J=2.8 \mathrm{~Hz}, 1 \mathrm{H}), 6.66(\mathrm{dd}, J=8.4,2.8 \mathrm{~Hz}, 1 \mathrm{H}$, $\operatorname{ArH}), 3.78(\mathrm{~s}, 3 \mathrm{H}, \mathrm{ArH}), 2.41\left(\mathrm{~s}, 3 \mathrm{H}, \mathrm{ArCH}_{3}\right), 1.81\left(\mathrm{tt}, J=8.4,5.4 \mathrm{~Hz}, 1 \mathrm{H}, \mathrm{CHCH}_{2}\right), 0.99-0.79(\mathrm{~m}$, $\left.2 \mathrm{H}, \mathrm{CHCH}_{2}\right), 0.67-0.52\left(\mathrm{~m}, 2 \mathrm{H}, \mathrm{CHCH}_{2}\right) .{ }^{13} \mathrm{C}$ NMR $\left(101 \mathrm{MHz}, \mathrm{CDCl}_{3}\right) \delta 157.8,139.5,133.6$, 
127.2, 115.6, 110.6, 55.3, 19.9, 13.0, 6.5. HRMS (APPI/LTQ-Orbitrap) m/z: [M] ${ }^{+}$Calcd for $\mathrm{C}_{11} \mathrm{H}_{14} \mathrm{O}^{+}$162.1039; Found 162.1038.

\section{2-Cyclopropyl-5-methoxy-1,3-dimethylbenzene (1g)}

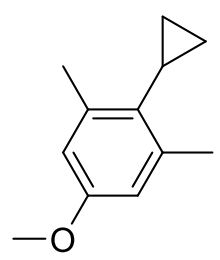

Following the general procedure A, starting from 2-bromo-5-methoxy-1,3-dimethylbenzene (1.08 g, $5.00 \mathrm{mmol}, 1.00$ equiv), obtained 2-cyclopropyl-5-methoxy-1,3-dimethylbenzene $\mathbf{1 g}$ (630 mg, $3.57 \mathrm{mmol}, 71 \%$ yield) as a colorless oil. $\mathbf{R f}=0.47\left(\mathrm{SiO}_{2}, 40: 1\right.$ pentane:ethyl acetate) ${ }^{1} \mathrm{H}$ NMR $\left(400 \mathrm{MHz}, \mathrm{CDCl}_{3}\right) \delta 6.57(\mathrm{~s}, 2 \mathrm{H}, \mathrm{ArH}), 3.77\left(\mathrm{~s}, 3 \mathrm{H}, \mathrm{OCH}_{3}\right), 2.42\left(\mathrm{~s}, 6 \mathrm{H}, \mathrm{ArCH}_{3}\right), 1.71-$ $1.58(\mathrm{~m}, 1 \mathrm{H}, \mathrm{ArCHCH} 2), 1.05-0.89\left(\mathrm{~m}, 2 \mathrm{H}, \mathrm{CHCH}_{2}\right), 0.57-0.43\left(\mathrm{~m}, 2 \mathrm{H}, \mathrm{CHCH}_{2}\right) .{ }^{13} \mathrm{C} \mathrm{NMR}$ (101 $\mathrm{MHz}_{1} \mathrm{CDCl}_{3}$ ) $\delta 157.7,140.4,131.7,113.2,55.2,21.0,11.5$, 8.2. HRMS (APPI/LTQ-Orbitrap) $\mathrm{m} / \mathrm{z}:[\mathrm{M}]^{+}$Calcd for $\mathrm{C}_{12} \mathrm{H}_{16} \mathrm{O}^{+}$176.1196; Found 176.1193 .

\section{1-cyclopropyl-4-fluoro-2-methoxybenzene (1h)}

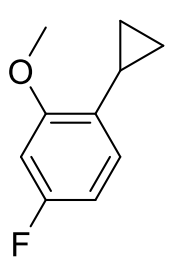

Following the general procedure A, starting from 1-bromo-4-fluoro-2-methoxybenzene (1.03 g, $5.00 \mathrm{mmol}, 1.00$ equiv), obtained 1-cyclopropyl-4-fluoro-2-methoxybenzene $1 \mathrm{~g}$ (540 mg, $3.25 \mathrm{mmol}, 65 \%$ yield$)$ as a colorless oil. $\mathbf{R f}=0.53\left(\mathrm{SiO}_{2}, 40: 1\right.$ pentane:ethyl acetate). ${ }^{1} \mathbf{H}$ NMR (400 MHz, CDCl $\left.{ }_{3}\right) \delta 6.89-6.75(\mathrm{~m}, 1 \mathrm{H}, \mathrm{ArH}), 6.64-6.52(\mathrm{~m}, 2 \mathrm{H}, \mathrm{ArH}), 3.85\left(\mathrm{~s}, 3 \mathrm{H}, \mathrm{OCH}_{3}\right), 2.13$ - $1.99\left(\mathrm{~m}, 1 \mathrm{H}, \mathrm{CHCH}_{2}\right), 0.97-0.83\left(\mathrm{~m}, 2 \mathrm{H}, \mathrm{CHCH}_{2}\right), 0.66-0.53\left(\mathrm{~m}, 2 \mathrm{H}, \mathrm{CHCH}_{2}\right) .{ }^{13} \mathrm{C}$ NMR (101 MHz, $\mathrm{CDCl}_{3}$ ) $\delta 161.8$ (d, J = 242.6 Hz), 159.4 (d, J = 9.5 Hz), 127.5 (d, J = 3.2 Hz), 125.9 (d, J = 9.7 Hz), 106.5 (d, $J=20.9 \mathrm{~Hz}), 98.7$ (d, $J=25.7 \mathrm{~Hz}), 55.8,9.3,7.4 .{ }^{19} \mathrm{~F} \mathrm{NMR}\left(376 \mathrm{MHz}, \mathrm{CDCl}_{3}\right) \delta$ -115.4. HRMS (APPI/LTQ-Orbitrap) m/z: [M] ${ }^{+}$Calcd for $\mathrm{C}_{10} \mathrm{H}_{11} \mathrm{FO}^{+}$166.0788; Found 166.0787 


\section{1-methoxy-4-(2-methylcyclopropyl)benzene (1i)}

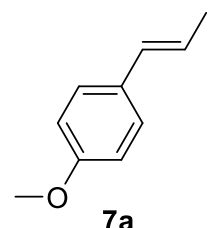

$7 a$
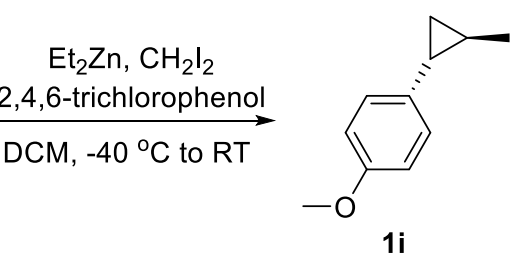

In a $250 \mathrm{~mL}$ oven-dried round-bottom flask with a stir bar, was added 2,4,6trichlorophenol (2.46 g, $12.50 \mathrm{mmol}, 2.5$ equiv) under nitrogen atmosphere. DCM (120 mL, $0.1 \mathrm{M})$ was added into the flask and the reaction mixture was cooled to $-40{ }^{\circ} \mathrm{C}$. $\mathrm{ZnEt}_{2}(1.0 \mathrm{M}$, $12.5 \mathrm{~mL}, 12.50 \mathrm{mmol}, 2.5$ equiv) was added slowly into the flask by syringe and the reaction mixture was stirred at this temperature for $15 \mathrm{~min} . \mathrm{CH}_{2} \mathrm{I}_{2}(5.29 \mathrm{~g}, 20.00 \mathrm{mmol}, 4.0$ equiv) was added slowly by syringe and the reaction mixture was stirred at this temperature for another $15 \mathrm{~min}$. Next, the corresponding solution of alkene $7 \mathrm{a}(741.0 \mathrm{mg}, 5.00 \mathrm{mmol}, 1.0$ equiv) in DCM $(20 \mathrm{~mL})$ was added by syringe and the reaction mixture was allowed to warm to room temperatureand stirred for $16 \mathrm{~h}$. After the reaction reached completion (as judged by $1 \mathrm{H}-$ $\mathrm{NMR})$, the reaction mixture was quenched with sat. $\mathrm{NH}_{4} \mathrm{Cl}(60 \mathrm{~mL})$ for 30 minutes and extracted with DCM $(100 \mathrm{~mL})$ for 3 times. The combined organic layers were washed with aq. $\mathrm{NaOH}(1.0 \mathrm{M}, 60 \mathrm{~mL})$ and brine $(40 \mathrm{~mL})$, dried over $\mathrm{Na}_{2} \mathrm{SO}_{4}$ and filtered. The resulted mixture was concentrated under reduced pressure, the crude residue was purified by column chromatography (Pentane : EtOAc $=50: 1$ to 10:1) to afford the desired compound 1methoxy-4-(2-methylcyclopropyl)benzene 1i (389 mg, $2.40 \mathrm{mmol}, 48 \%$ ) as colorless oil. ${ }^{1} \mathrm{H}$ NMR $\left(400 \mathrm{MHz}, \mathrm{CDCl}_{3}\right) \delta 7.01-6.96(\mathrm{~m}, 2 \mathrm{H}, \mathrm{ArH}), 6.84-6.78(\mathrm{~m}, 2 \mathrm{H}, \mathrm{ArH}), 3.80(\mathrm{~s}, 3 \mathrm{H}$, $\left.\mathrm{OCH}_{3}\right), 1.60-1.51\left(\mathrm{~m}, 1 \mathrm{H}, \mathrm{ArCHCH}_{2}\right), 1.19$ (d, J = 5.9 Hz, 3H, $\left.\mathrm{CH}_{2} \mathrm{CHCH}_{3}\right), 1.04-0.93(\mathrm{~m}, 1 \mathrm{H}$, $\left.\mathrm{CHCH}_{3}\right) 0.84-0.79\left(\mathrm{~m}, 1 \mathrm{H}, \mathrm{ArCHCH}_{2}\right), 0.69-0.62\left(\mathrm{~m}, 1 \mathrm{H}, \mathrm{ArCHCH}_{2}\right) .{ }^{13} \mathrm{C} \mathrm{NMR}\left(101 \mathrm{MHz}, \mathrm{CDCl}_{3}\right)$ $\delta 157.6,136.1,126.7,113.8,55.4,23.5,19.3,17.3,16.9$. Consistent with reported data. ${ }^{3}$ 


\section{Synthesis of 1-(2,2-dimethylcyclopropyl)-4-methoxybenzene (1j)}

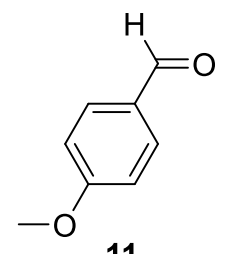

11
$\underset{\mathrm{THF}, 0^{\circ} \mathrm{C}, 30 \mathrm{~min}}{\stackrel{i \mathrm{PrPPh}_{3} \mathrm{l}, \mathrm{n}-\mathrm{BuLi}}{\longrightarrow}}$

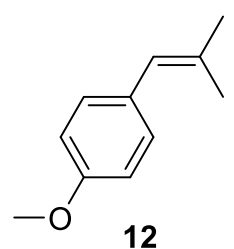

12
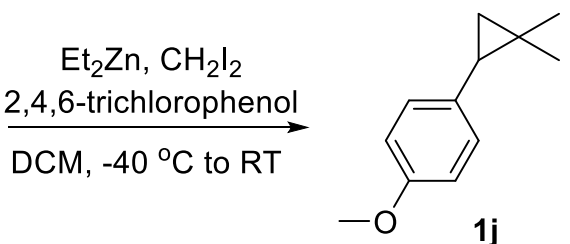

To a $250 \mathrm{~mL}$ oven-dried round-bottom flask equiped with a stirring bar, isopropyltriphenylphosphonium iodide $(6.0 \mathrm{~g}, 14 \mathrm{mmol}, 1.2$ equiv) and anhydrous THF (70 $\mathrm{mL}$, $0.2 \mathrm{M})$ were added. The reaction flaskwas capped with rubber septum and three cycles of evacuate-refill with nitrogen were performed, then the reaction mixture was cooled to $0{ }^{\circ} \mathrm{C}$. n-BuLi (2.5 M, $5.6 \mathrm{~mL}, 14 \mathrm{mmol}, 1.2$ equiv) was added dropwise by syringe and the reaction mixture was stirred at this temperature for $30 \mathrm{~min}$. A solution of aldehyde $\mathbf{1 1}$ (1577 mg, $11.60 \mathrm{mmol}, 1.0$ equiv) in THF (20 mL) was added by syringe and the reaction mixture was allowed to warm to room temperature, and then stirred for $16 \mathrm{~h}$. After the reaction reached completion according to the TLC analysis, the reaction mixture was quenched by sat. $\mathrm{NH}_{4} \mathrm{Cl}(30 \mathrm{~mL})$ and extracted with EtOAc $(100 \mathrm{~mL})$ for 3 times. The combined organic layers were washed with $\mathrm{H}_{2} \mathrm{O}_{2}(10 \mathrm{wt} \%$ in water, $10 \mathrm{~mL})$ and brine $(20 \mathrm{~mL})$, dried over $\mathrm{Na}_{2} \mathrm{SO}_{4}$, and filtered. After that, the mixture was concentrated under reduced pressure, the crude residue was purified by column chromatography (Pentant : EtOAc $=50: 1$ to 10: 1 ) to afford the desired alkene $\mathbf{1 2}$ as colorless oil.

In a $150 \mathrm{~mL}$ oven-dried round-bottom flask with a stirring bar, was added 2,4,6trichlorophenol (2.46 g, $12.5 \mathrm{mmol}, 2.5$ equiv) under nitrogen atmosphere. DCM (120 mL, $0.1 \mathrm{M})$ was added into the flask and the reaction mixture was cooled to $-40{ }^{\circ} \mathrm{C}$. $\mathrm{ZnEt}_{2}(1.0 \mathrm{M}$, $12.5 \mathrm{~mL}, 12.5 \mathrm{mmol}, 2.5$ equiv) was added slowly into the flask by syringe and the reaction mixture was stirred at this temperature for $15 \mathrm{~min} . \mathrm{CH}_{2} \mathrm{I}_{2}(5.29 \mathrm{~g}, 20.0 \mathrm{mmol}, 4.0$ equiv) was added slowly by syringe and the reaction mixture was stirred at this temperature for another $15 \mathrm{~min}$. Next, a solution of alkene 12 (808 mg, $5.00 \mathrm{mmol}, 1.0$ equiv) in DCM (20 mL) was added by syringe and the reaction mixture was allowed to warm to room temperature and stirred for $16 \mathrm{~h}$. After the reaction reached completion, the reaction mixture was quenched with sat. $\mathrm{NH}_{4} \mathrm{Cl}(60 \mathrm{~mL})$ in 30 minutes and extracted with $\mathrm{DCM}(100 \mathrm{~mL})$ for 3 times. The combined organic layers were washed with aq. $\mathrm{NaOH}(1.0 \mathrm{M}, 60 \mathrm{~mL})$ and brine, dried over 
$\mathrm{Na}_{2} \mathrm{SO}_{4}$ and filtered. After the volatile materials were removed under reduced pressure, the crude residue was purified by column chromatography (Pentane : EtOAc $=50: 1$ to $10: 1$ ) to afford 1-(2,2-dimethylcyclopropyl)-4-methoxybenzene (1j) (458 mg, $2.60 \mathrm{mmol}, 52 \%)$ as colorless oil

${ }^{1} \mathrm{H}$ NMR $\left(400 \mathrm{MHz}, \mathrm{CDCl}_{3}\right) \delta 7.1-7.0(\mathrm{~m}, 2 \mathrm{H}), 6.9-6.8(\mathrm{~m}, 2 \mathrm{H}), 3.8(\mathrm{~d}, J=1.6 \mathrm{~Hz}, 3 \mathrm{H}), 1.9-$ $1.7(\mathrm{~m}, 1 \mathrm{H}), 1.2(\mathrm{~d}, J=1.6 \mathrm{~Hz}, 3 \mathrm{H}), 0.8(\mathrm{~d}, J=1.7 \mathrm{~Hz}, 3 \mathrm{H}), 0.8-0.6(\mathrm{~m}, 2 \mathrm{H}) .{ }^{13} \mathrm{C}$ NMR $(101 \mathrm{MHz}$, $\left.\mathrm{CDCl}_{3}\right) \delta 157.7,132.6,130.0,113.4,55.4,29.0,27.5,20.6,18.6,18.5$. Consistent with reported data. $^{3}$

\section{2-Cyclopropyl-1,3-dimethylbenzene (1k)}

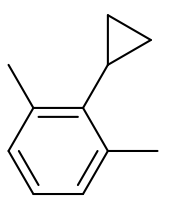

Following the general procedure D, starting from 2-bromo-1,3-dimethylbenzene $(925 \mathrm{mg}$, $5.00 \mathrm{mmol}, 1.00$ equiv), 2-cyclopropyl-1,3-dimethylbenzene (1k) (530 mg, $3.62 \mathrm{mmol}, 72 \%$ yield) was obtained as a colorless oil. ${ }^{1} \mathbf{H}$ NMR (400 MHz, $\left.\mathrm{CDCl}_{3}\right) \delta 7.09-6.95(\mathrm{~m}, 3 \mathrm{H}, \mathrm{ArH})$, $2.43\left(\mathrm{~s}, 6 \mathrm{H}, \mathrm{ArCH}_{3}\right), 1.71$ (ddd, J=14.4, 8.4, $\left.6.0 \mathrm{~Hz}, 1 \mathrm{H}, \mathrm{ArCHCH}_{3}\right), 1.10-0.97\left(\mathrm{~m}, 2 \mathrm{H}, \mathrm{CH}_{2}\right.$ ), $0.60-0.49\left(\mathrm{~m}, 2 \mathrm{H}, \mathrm{CH}_{2}\right) .{ }^{13} \mathrm{C}$ NMR $\left(101 \mathrm{MHz} \mathrm{CDCl}_{3}\right) \delta 139.1,139.0,127.9,126.1,20.7,12.2$, 8.1. HRMS (APPI/LTQ-Orbitrap) $\mathrm{m} / \mathrm{z}$ : [M] ${ }^{+}$Calcd for $\mathrm{C}_{11} \mathrm{H}_{14}{ }^{+} 146.1090$; Found 146.1088 Consistent with reported data. ${ }^{4}$

\section{$\mathrm{N}$-cyclopropyl-4- methylbenzamide (5a)}

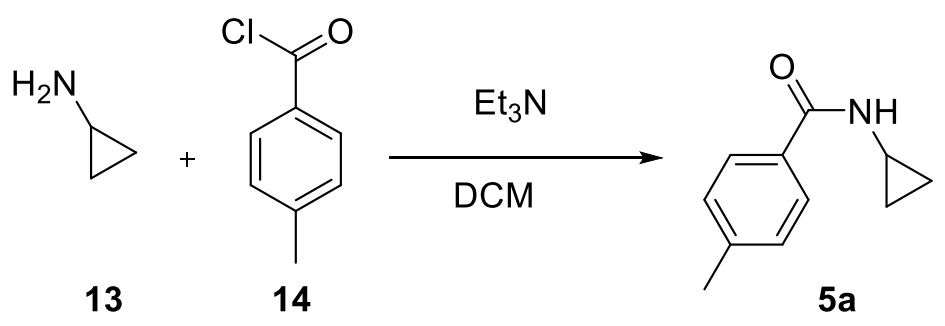

Following a modified version of a reported procedure, ${ }^{5}$ to a solution of cyclopropylamine (13) (0.70 mL, $10 \mathrm{mmol}, 1.1$ equiv.) and triethylamine (1.40 mL, $10.0 \mathrm{mmol}, 1.1$ equiv.) in dichloromethane $(10 \mathrm{~mL}$ ) was slowly added a solution of 4-methylbenzoyl chloride (14) (1.41 $\mathrm{g}, 9.09 \mathrm{mmol})$ in dichloromethane $(10 \mathrm{~mL})$ at $0{ }^{\circ} \mathrm{C}$. The reaction mixture was stirred at room temperature for 16 hours. Upon completion, the mixture was quenched by the addition of 1 
$\mathrm{N} \mathrm{HCl}(10 \mathrm{~mL})$. The aqueous layer was then extracted with dichloromethane. The organic extract was washed with $1 \mathrm{M} \mathrm{NaOH}(10 \mathrm{~mL})$ and brine $(10 \mathrm{~mL})$, dried over $\mathrm{Na}_{2} \mathrm{SO}_{4}$, filtered and concentrated in vacuo. The crude product 5a was pure enough to be used as such, without further purification.

${ }^{1} \mathrm{H}$ NMR $\left(400 \mathrm{MHz}, \mathrm{CDCl}_{3}\right): \delta=7.72-7.55(\mathrm{~m}, 2 \mathrm{H}, \operatorname{ArH}), 7.23-7.11(\mathrm{~m}, 2 \mathrm{H}, \operatorname{ArH}), 6.33(\mathrm{~d}, J=$ $39.2 \mathrm{~Hz}, 1 \mathrm{H}, \mathrm{NH}), 2.88(\mathrm{tt}, J=7.2,3.5 \mathrm{~Hz}, 1 \mathrm{H}, \mathrm{CH}), 2.37\left(\mathrm{~d}, J=3.1 \mathrm{~Hz}, 3 \mathrm{H}, \mathrm{CH}_{3}\right), 0.92-0.75(\mathrm{~m}$, $\left.2 \mathrm{H}, \mathrm{CH}_{2}\right), 0.68-0.54\left(\mathrm{~m}, 2 \mathrm{H}, \mathrm{CH}_{2}\right) .{ }^{1} \mathrm{H}$ NMR data correspond to the reported values. ${ }^{6}$

Synthesis of hypervalent iodine reagents<smiles>O=C1OI(C#Cc2ccccc2)c2ccccc21</smiles>

2a

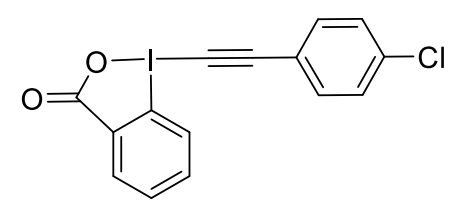

2d

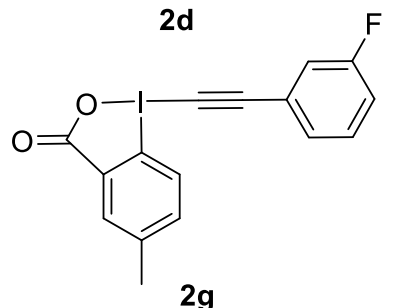

2g

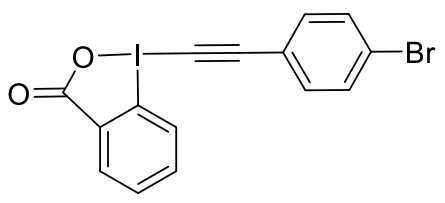

2j<smiles>Cc1ccc(C#CI2OC(=O)c3ccccc32)cc1</smiles>

2b<smiles>O=C1OI(C#Cc2ccc(F)cc2)c2ccccc21</smiles>

$2 e$<smiles>COc1cc2c(cc1OC)I(C#Cc1ccccc1)OC2=O</smiles><smiles>O=C1OI(C#Cc2ccccc2Br)c2ccccc21</smiles>

2k<smiles>O=C1OI(C#Cc2ccc(C(F)(F)F)cc2)c2ccccc21</smiles><smiles>O=C1OI(C#Cc2cccc(F)c2)c2ccccc21</smiles>

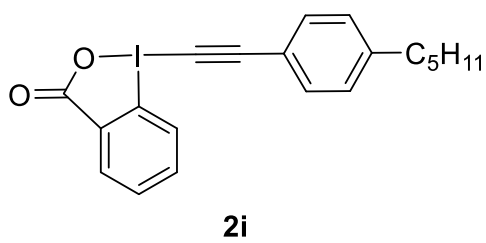




\section{1-Hydroxy-1,2-benziodoxol-3-(1H)-one (BIOH, 16)}<smiles>O=C(O)c1ccccc1I</smiles>

15

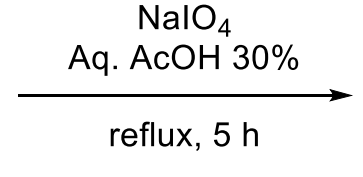

reflux, $5 \mathrm{~h}$<smiles>O=C1OI(O)c2ccccc21</smiles>

16

$\mathrm{NaIO}_{4}$ (40.5 g, $189 \mathrm{mmol}, 1.05$ equiv) and 2-iodobenzoic acid (15) (44.8 g, $180 \mathrm{mmol}, 1.0$ equiv) were suspended in $30 \%(\mathrm{v}: \mathrm{v})$ aq. $\mathrm{AcOH}(350 \mathrm{~mL})$. The mixture was vigorously stirred and refluxed for $5 \mathrm{~h}$. The reaction mixture was then diluted with cold water $(250 \mathrm{~mL})$ and allowed to cool to rt, protecting it from light. After $1 \mathrm{~h}$, the crude product was collected by filtration, washed on the filter with ice water $(3 \times 150 \mathrm{~mL})$ and acetone $(3 \times 150 \mathrm{~mL})$, and air-dried in the dark overnight to afford 1-hydroxy-1,2-benziodoxol-3-(1H)-one $\mathrm{BIOH}$ (16) (44.3 g, $168 \mathrm{mmol}$, 93\% yield) as a white solid. ${ }^{1} \mathrm{H}$ NMR $\left(400 \mathrm{MHz}, \mathrm{DMSO}-d_{6}\right) \delta 8.02(\mathrm{dd}, J=7.7,1.4 \mathrm{~Hz}, 1 \mathrm{H}, \operatorname{Ar} H)$, $7.97(\mathrm{~m}, 1 \mathrm{H}, \mathrm{ArH}), 7.85(\mathrm{dd}, J=8.2,0.7 \mathrm{~Hz}, 1 \mathrm{H}, \mathrm{ArH}), 7.71(\mathrm{td}, J=7.6,1.2 \mathrm{~Hz}, 1 \mathrm{H}, \operatorname{ArH}) .{ }^{13} \mathrm{C}$ NMR $\left(100 \mathrm{MHz}, \mathrm{DMSO}-d_{6}\right) \delta 167.7,134.5,131.5,131.1,130.4,126.3,120.4$. Consistent with reported data ${ }^{7}$

\section{1-[Phenylethynyl]-1,2-benziodoxol-3(1H)-one (PhEBX) (2a)}<smiles>O=C1OI(O)c2ccccc21</smiles>

16

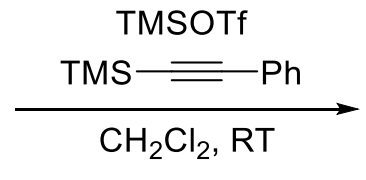

$\mathrm{CH}_{2} \mathrm{Cl}_{2}, \mathrm{RT}$<smiles>O=C1OI(C#Cc2ccccc2)c2ccccc21</smiles>

$2 a$

Trimethylsilyltriflate $(9.1 \mathrm{~mL}, 50 \mathrm{mmol}, 1.1$ equiv) was added dropwise to a suspension of 2iodosylbenzoic acid (16) $\left(12.1 \mathrm{~g}, 45.8 \mathrm{mmol}, 1.0\right.$ equiv) in $\mathrm{CH}_{2} \mathrm{Cl}_{2}(120 \mathrm{~mL})$ at $0{ }^{\circ} \mathrm{C}$. The mixture was stirred for $1 \mathrm{~h}$, followed by the dropwise addition of trimethyl(phenylethynyl)silane (8.8 $\mathrm{mL}, 50 \mathrm{mmol}, 1.1$ equiv) (slightly exothermic). The resulting suspension was stirred for $6 \mathrm{~h}$ at $\mathrm{RT}$, during this time a white solid was formed. A saturated solution of $\mathrm{NaHCO}_{3}(120 \mathrm{~mL})$ was added and the mixture was stirred vigorously for $30 \mathrm{~min}$. The mixture was extracted with $\mathrm{H}_{2} \mathrm{O}$ and DCM $(3 \times 50 \mathrm{~mL})$, washed with brine, then dried over $\mathrm{Na}_{2} \mathrm{SO}_{4}$, filtered and evaporated under reduced pressure. The resulting solid was recrystalized in EtOAc:MeOH (2:1) (40 $\mathrm{mL}$ /grams). The solution was left to cool to RT overnight. The slow recrystallization is important to obtain pure product $\mathbf{2 a}$ (photo of crystal obtained below). The crystal formed was filtered and dried under high vacuum to afford PhEBX (2a) $(5.89 \mathrm{~g}, 16.95 \mathrm{mmol}, 37 \%$ 
yield) as colorless crystals. ${ }^{1} \mathrm{H}$ NMR $\left(400 \mathrm{MHz}, \mathrm{CDCl}_{3}\right) \delta 8.46(\mathrm{~m}, 1 \mathrm{H}, \mathrm{ArH}), 8.28(\mathrm{~m}, 1 \mathrm{H}, \mathrm{ArH})$, $7.80(\mathrm{~m}, 2 \mathrm{H}, \mathrm{ArH}), 7.63(\mathrm{~m}, 2 \mathrm{H}, \mathrm{ArH}), 7.48(\mathrm{~m}, 3 \mathrm{H}, \mathrm{ArH}) .{ }^{13} \mathrm{C} \mathrm{NMR}\left(101 \mathrm{MHz}, \mathrm{CDCl}_{3}\right) \delta$ 163.9, 134.9, 132.9, 132.5, 131.6, 131.3. 130.8, 128.8, 126.2, 120.5, 116.2, 106.6, 50.2. Consistent with reported data ${ }^{8}$

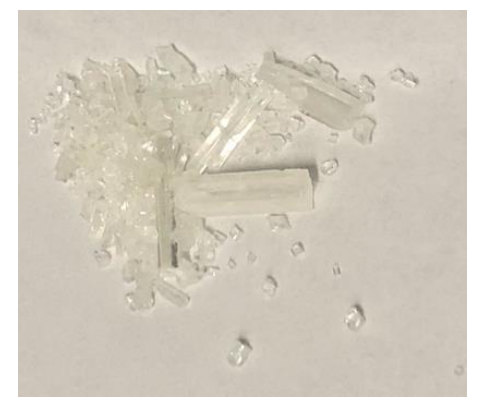

PhEBX with crystallization at RT

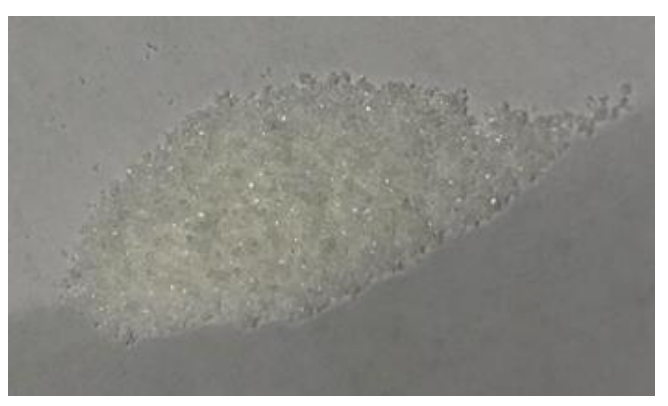

PhEBX with fast crystallization in the fridge

1-(p-Tolylethynyl)-1,2-benziodoxol-3(1H)-one (2b)<smiles>O=C1OI(O)c2ccccc21</smiles>

16

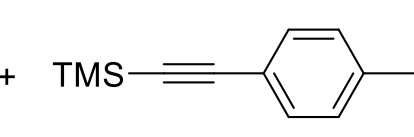

17

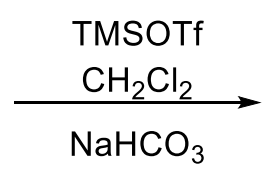

$\mathrm{NaHCO}_{3}$

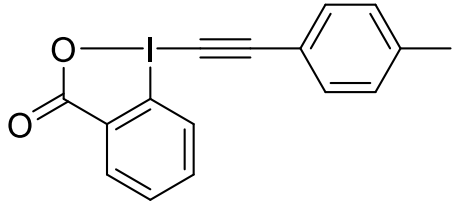

2b

Following a reported procedure, ${ }^{9}$ trimethylsilyl triflate $(1.0 \mathrm{~mL}, 5.5 \mathrm{mmol}, 1.1$ equiv) was added to a suspension of 2-iodosylbenzoic acid (16) (1.32 g, $5.00 \mathrm{mmol}, 1.00$ equiv) in $\mathrm{CH}_{2} \mathrm{Cl}_{2}$ $(15 \mathrm{~mL})$ at room temperature. The resulting suspension was stirred for $3 \mathrm{~h}$, followed by the drop wise addition of trimethyl(p-tolylethynyl)silane (17) (1.04 g, $5.50 \mathrm{mmol}, 1.10$ equiv). The resulting suspension was stirred for $6 \mathrm{~h}$ at room temperature. A saturated solution of $\mathrm{NaHCO}_{3}$ $(20 \mathrm{~mL})$ was then added and the mixture was stirred vigorously for 30 minutes. The mixture was extracted with $\mathrm{H}_{2} \mathrm{O}$ and $\mathrm{DCM}(3 \times 20 \mathrm{~mL})$, washed with brine, then dried over $\mathrm{Na}_{2} \mathrm{SO}_{4}$, filtered and evaporated under reduced pressure. The resulting solid was recrystalized in EtOAc:MeOH (2:1) (40 ml/gram). The solution was left to cool to RT overnight.. The crystal formed was filtered and dried under high vacuum to afford $\mathbf{2 b}(0.620 \mathrm{~g}, 1.71 \mathrm{mmol}, 34 \%)$ as a white crystals. ${ }^{1} \mathrm{H}$ NMR $\left(400 \mathrm{MHz}, \mathrm{CDCl}_{3}\right) \delta 8.43(\mathrm{dd}, J=6.1,2.9 \mathrm{~Hz}, 1 \mathrm{H}, \mathrm{ArH}), 8.30-8.14(\mathrm{~m}$, $1 \mathrm{H}, \operatorname{ArH}), 7.77(\mathrm{dd}, J=6.9,3.1 \mathrm{~Hz}, 2 \mathrm{H}, \operatorname{ArH}), 7.50(\mathrm{~d}, J=7.8 \mathrm{~Hz}, 2 \mathrm{H}, \operatorname{ArH}), 7.25(\mathrm{~d}, J=7.6 \mathrm{~Hz}, 2 \mathrm{H}$, $\operatorname{ArH}), 2.43(\mathrm{~s}, 3 \mathrm{H}, \mathrm{ArCH}) .{ }^{13} \mathrm{C}$ NMR $(100 \mathrm{MHz}, \mathrm{CDCl}): \delta 166.6,141.5,134.9,132.8,132.5$, 131.6, 131.3, 129.5, 126.2, 117.4, 116.2, 107.25, 49.1, 21.7. Consistent with reported data. ${ }^{9}$ 
1-(p-trifluoromethylethynyl)-1,2-benziodoxol-3(1H)-one (2c)<smiles>O=C1OI(O)c2ccccc21</smiles>

16<smiles>CC#Cc1ccc(C(F)(F)F)cc1</smiles>

18<smiles>O=C1OI(C#Cc2ccc(C(F)(F)F)cc2)c2ccccc21</smiles>

Following a reported procedure, ${ }^{9}$ trimethylsilyl triflate $(1.0 \mathrm{~mL}, 5.5 \mathrm{mmol}, 1.1$ equiv) was added to a suspension of $\mathrm{BIOH}(16)\left(1.3 \mathrm{~g}, 5.0 \mathrm{mmol}, 1.0\right.$ equiv) in $\mathrm{CH}_{2} \mathrm{Cl}_{2}$ (15 mL) at RT The resulting suspension was stirred for $1 \mathrm{~h}$, followed by the dropwise addition of trimethyl((4(trifluoromethyl)phenyl)ethynyl)silane (18) (1.3 mL, $5.5 \mathrm{mmol}, 1.1$ equiv), which was dissolved in $\mathrm{CH}_{2} \mathrm{Cl}_{2}(1 \mathrm{~mL})$. The resulting suspension was stirred for $6 \mathrm{~h}$ at RT. A saturated solution of $\mathrm{NaHCO}_{3}(20 \mathrm{~mL})$ was then added and the mixture was stirred vigorously for $30 \mathrm{~min}$, the two layers were separated and the organic layer was washed with sat. $\mathrm{NaHCO}_{3}(20 \mathrm{~mL})$, dried over $\mathrm{MgSO}_{4}$, filtered and evaporated under reduced pressure. The resulting solid was boiled in $\mathrm{CH}_{3} \mathrm{CN}(20 \mathrm{~mL})$. The mixture was cooled down, filtered and dried under high vacuum to afford 2c (1.12 g, $2.69 \mathrm{mmol}, 54 \%$ yield) as a pale yellow solid. ${ }^{1} \mathbf{H}$ NMR (400 MHz, $\left.\mathrm{CDCl}_{3}\right) \delta 8.46-$ $8.38(\mathrm{~m}, 1 \mathrm{H}, \mathrm{ArH}), 8.28-8.19(\mathrm{~m}, 1 \mathrm{H}, \mathrm{ArH}), 7.84-7.74(\mathrm{~m}, 2 \mathrm{H}, \mathrm{ArH}), 7.74-7.65(\mathrm{~m}, 4 \mathrm{H}, \mathrm{ArH})$. ${ }^{13} \mathrm{C}$ NMR (101 MHz, $\left.\mathrm{CDCl}_{3}\right) \delta$ 166.6, 135.0, 133.0, 132.6, 132.2 (q, J = 33.0 Hz), 131.7, 131.2, 126.3, $125.7(q, J=3.6 \mathrm{~Hz}), 124.4,123.4(q, J=272.6 \mathrm{~Hz}), 116.1,104.2,53.7$. Consistent with reported data. ${ }^{9}$

\section{1-[4-Chlorophenylethynyl]-1,2-benziodoxol-3(1H)-one (2d)}<smiles>O=C1OI(O)c2ccccc21</smiles>

16<smiles>CSC#Cc1ccc(Cl)cc1</smiles>

19<smiles>CCCOS(C)(=O)=O</smiles><smiles>O=C1OI(C#Cc2ccc(Cl)cc2)c2ccccc21</smiles>

2d

Following a reported procedure, ${ }^{10}$ Trimethylsilyl triflate $(1.0 \mathrm{~mL}, 5.5 \mathrm{mmol}, 1.1$ equiv) was added to a suspension of $\mathrm{BIOH}$ (16) (1.32 g, $5.00 \mathrm{mmol}, 1.0$ equiv) in $\mathrm{CH}_{2} \mathrm{Cl}_{2}$ (15 mL) at RT. The resulting suspension was stirred for $1 \mathrm{~h}$, followed by the dropwise addition of ((4Chlorophenyl)ethynyl)trimethylsilane $(0.68 \mathrm{~mL}, 5.00 \mathrm{mmol}, 1.0$ equiv), which was dissolved in $\mathrm{CH}_{2} \mathrm{Cl}_{2}$ (5 mL). The resulting suspension was stirred for $6 \mathrm{~h}$ at RT. A saturated solution of $\mathrm{NaHCO}_{3}(20 \mathrm{~mL})$ was then added and the mixture was stirred vigorously for 30 minutes, the two layers were separated. The mixture was extracted with $\mathrm{H}_{2} \mathrm{O}$ and DCM $(3 \times 20 \mathrm{~mL})$, washed 
with brine, then dried over $\mathrm{Na}_{2} \mathrm{SO}_{4}$ filtered and evaporated under reduced pressure. The resulting solid was recrystalized in EtOAc:MeOH (2:1) (40 mL/gram). The solution was left to cool to RT overnight. The crystal formed was filtered and dried under high vacuum to afford (2d) as a white solid (658 mg, $1.72 \mathrm{mmol}, 34 \%) .{ }^{1} \mathrm{H}$ NMR (400 MHz, CDCl3) $\delta 8.41-8.39(\mathrm{~m}, 1 \mathrm{H}$, $\operatorname{ArH})$, 8.23-8.21 (m, 1H, ArH), 7.80-7.73 (m, 2H, ArH), 7.54-7.51 (m, 2H, ArH), 7.42-7.38 (m, 2H, ArH). ${ }^{13} \mathrm{C}$ NMR (100 MHz, CDCl3) $\delta$ 166.85, 137.20, 135.07, 134.17, 132.61, 131.74, 131.47, $129.29,126.48,119.16,116.32,105.22,51.80$. Consistent with reported data. ${ }^{10}$

\section{1-[4-Fluorophenylethynyl]-1,2-benziodoxol-3(1H)-one (2e)}<smiles>O=C1OI(O)c2ccccc21</smiles>

16

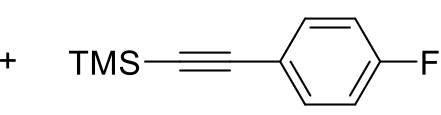

20

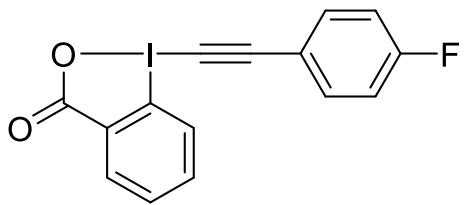

$2 e$

Following a reported procedure, ${ }^{11}$ Trimethylsilyl triflate $(1.0 \mathrm{~mL}, 5.5 \mathrm{mmol}, 1.1$ equiv) was added to a suspension of 2-iodosylbenzoic acid (16) (1.32 g, $5.00 \mathrm{mmol}, 1.0$ equiv) in $\mathrm{CH}_{2} \mathrm{Cl}_{2}$ $(15 \mathrm{~mL})$ at RT. The resulting suspension was stirred for $1 \mathrm{~h}$, followed by the drop wise addition of ((4-fluorophenyl)ethynyl)trimethylsilane (20) $(1.1 \mathrm{~mL}, 5.5 \mathrm{mmol}, 1.1$ equiv), which was dissolved in $\mathrm{CH}_{2} \mathrm{Cl}_{2}(1 \mathrm{~mL})$. The resulting suspension was stirred for $6 \mathrm{~h}$ at RT. A saturated solution of $\mathrm{NaHCO}_{3}(20 \mathrm{~mL})$ was then added and the mixture was stirred vigorously for 30 minutes, the two layers were separated. The mixture was extracted with $\mathrm{H}_{2} \mathrm{O}$ and DCM $(3 \times 20$ $\mathrm{mL}$ ), washed with brine, then dried over $\mathrm{Na}_{2} \mathrm{SO}_{4}$ filtered and evaporated under reduced pressure. The resulting solid was recrystalized in EtOAc:MeOH (2:1) (40 mL/gram). The solution was left to cool to RT overnight. The crystal formed was filtered and dried under high vacuum to afford product $2 \mathrm{e}(739 \mathrm{mg}, 2.02 \mathrm{mmol}, 40 \%)$ as a white solid. ${ }^{1} \mathbf{H}$ NMR (400 MHz, Chloroform-d) $\delta 8.48-8.34(\mathrm{~m}, 1 \mathrm{H}, \mathrm{ArH}), 8.29-8.16(\mathrm{~m}, 1 \mathrm{H}, \mathrm{ArH}), 7.85-7.69(\mathrm{~m}, 2 \mathrm{H}, \mathrm{ArH})$, $7.68-7.53(\mathrm{~m}, 2 \mathrm{H}, \mathrm{ArH}), 7.17-7.05$ (m, 2H, ArH). ${ }^{13} \mathrm{C}$ NMR (101 MHz, Chloroform-d) $\delta 166.8$, $164.0(\mathrm{~d}, \mathrm{~J}=253.9 \mathrm{~Hz}$ ), 135.2 (d, J = 8.8 Hz), 135.0, 132.6, 131.7, 131.50, 126.4, 116.9 (d, J = 3.6 Hz), $116.4(d, J=22.4 \mathrm{~Hz}), 116.3,105.5,50.5$. Consistent with reported data. ${ }^{11}$ 


\section{1-[3-Fluorophenylethynyl]-1,2-benziodoxol-3(1H)-one (2f)}<smiles>O=C1OI(O)c2ccccc21</smiles>

16

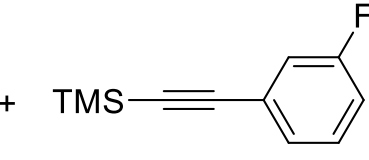

21

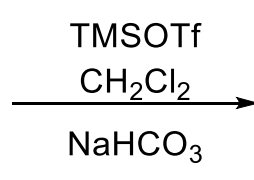

$\mathrm{NaHCO}_{3}$

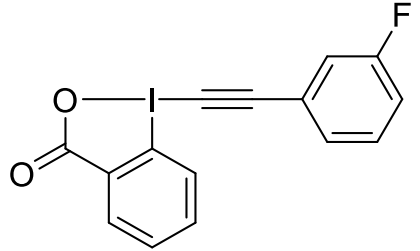

$2 f$

Following reported procedure, ${ }^{9}$ Trimethylsilyl triflate $(0.44 \mathrm{~mL}, 2.5 \mathrm{mmol}, 1.1$ equiv) was added to a suspension of 2-iodosylbenzoic acid (16) ( $0.589 \mathrm{~g}, 2.23 \mathrm{mmol}, 1.00$ equiv) in $\mathrm{CH}_{2} \mathrm{Cl}_{2}$ $(6.8 \mathrm{~mL})$ at RT The resulting suspension was stirred for $1 \mathrm{~h}$, followed by the dropwise addition of ((3-fluorophenyl)ethynyl)trimethylsilane (21) $(0.50 \mathrm{~mL}, 2.5 \mathrm{mmol}, 1.1$ equiv). The resulting suspension was stirred for $6 \mathrm{~h}$ at RT. A saturated solution of $\mathrm{NaHCO}_{3}(10 \mathrm{~mL})$ was then added and the mixture was stirred vigorously for 30 minutes, resulting in a suspension. The mixture was extracted with $\mathrm{H}_{2} \mathrm{O}$ and $\mathrm{DCM}(3 \times 10 \mathrm{~mL})$, washed with brine, then dried over $\mathrm{Na}_{2} \mathrm{SO}_{4}$, filtered and evaporated under reduced pressure. The resulting solid was recrystalized in EtOAc:MeOH (2:1) (40 mL/gram). The solution was left to cool to RT and kept in fridge overnight. The crystal formed was filtered and dried under high vacuum to afford product $\mathbf{2 f}$ (384 mg, 1.05 mmol, 47\% yield) as colorless crystals. ${ }^{1} \mathrm{H}$ NMR (400 MHz, DMSO- $d_{6}$ ) $\delta 8.33$ (dd, $J=8.2,0.8 \mathrm{~Hz}, 1 \mathrm{H}, \operatorname{ArH}), 8.13(\mathrm{dd}, J=7.4,1.7 \mathrm{~Hz}, 1 \mathrm{H}, \operatorname{ArH}), 7.91$ (ddd, $J=8.2,7.2,1.7 \mathrm{~Hz}, 1 \mathrm{H}$, $\operatorname{ArH}), 7.81(\mathrm{td}, J=7.3,0.9 \mathrm{~Hz}, 1 \mathrm{H}, \operatorname{ArH}), 7.64-7.59(\mathrm{~m}, 1 \mathrm{H}, \operatorname{ArH}), 7.58-7.53(\mathrm{~m}, 2 \mathrm{H}, \operatorname{ArH}), 7.47$ - $7.37(\mathrm{~m}, 1 \mathrm{H}, \mathrm{ArH}) .{ }^{13} \mathrm{C}$ NMR (101 MHz, DMSO-d6) 166.3, 161.8 (d, J = 245.6 Hz), 135.3, 131.9, 131.3, 131.2 (d, $J=8.7 \mathrm{~Hz}), 129.0(\mathrm{~d}, J=2.9 \mathrm{~Hz}), 127.7,122.4$ (d, $J=9.6 \mathrm{~Hz}), 119.2(\mathrm{~d}, J=23.4$ $\mathrm{Hz}), 118.1(\mathrm{~d}, J=21.1 \mathrm{~Hz}), 116.4,102.5(\mathrm{~d}, J=3.3 \mathrm{~Hz}), 53.8$. (One carbon is not resolved) Consistent with reported data. ${ }^{9}$ 


\section{Synthesis of $\mathbf{2 g}$}

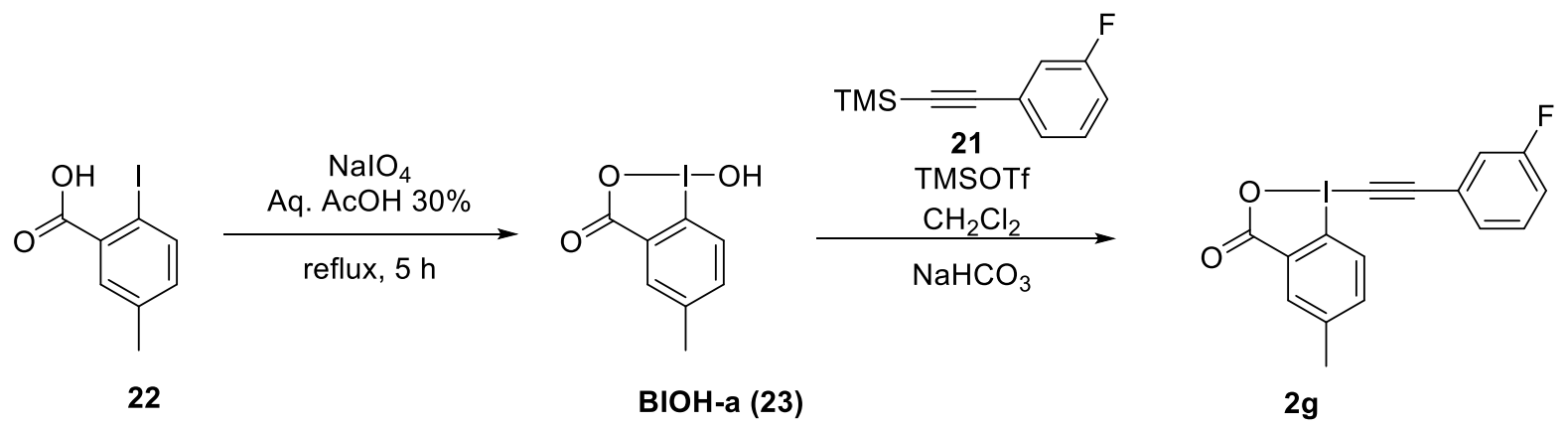

$\mathrm{NaIO}_{4}$ (4.05 g, 18.9 mmol, 1.05 equiv) and 2-iodo-5-methylbenzoic acid (22) (4.7 g, 18 mmol, 1.0 equiv) were suspended in $30 \%$ (v:v) aq. $\mathrm{AcOH}(35 \mathrm{~mL}$ ). The mixture was vigorously stirred and refluxed for $5 \mathrm{~h}$. The reaction mixture was then diluted with cold water $(25 \mathrm{~mL})$ and allowed to cool to rt, protecting it from light. After $1 \mathrm{~h}$, the crude product was collected by filtration, washed on the filter with ice water $(3 \times 15 \mathrm{~mL})$ and acetone $(3 \times 15 \mathrm{~mL})$, and airdried in the dark overnight to afford BIOH-a (23) (3.95 g, $14.2 \mathrm{mmol}, 79 \%$ yield) as a white solid.

Trimethylsilyl triflate (0.44 mL, $2.5 \mathrm{mmol}, 1.1$ equiv) was added to a suspension BIOH-a (23) ( $0.620 \mathrm{~g}, 2.23 \mathrm{mmol}, 1.00$ equiv) in $\mathrm{CH}_{2} \mathrm{Cl}_{2}(6.8 \mathrm{~mL}$ ) at $\mathrm{RT}$ The resulting suspension was stirred for $1 \mathrm{~h}$, followed by the dropwise addition of ((3-fluorophenyl)ethynyl)trimethylsilane (21) (0.50 mL, $2.5 \mathrm{mmol}, 1.1$ equiv). The resulting suspension was stirred for $6 \mathrm{~h}$ at RT. A saturated solution of $\mathrm{NaHCO}_{3}(10 \mathrm{~mL})$ was then added and the mixture was stirred vigorously for 30 minutes, resulting in a suspension. The mixture was extracted with $\mathrm{H}_{2} \mathrm{O}$ and $\mathrm{DCM}(3 \times 10 \mathrm{~mL})$, washed with brine, then dried over $\mathrm{Na}_{2} \mathrm{SO}_{4}$, filtered and evaporated under reduced pressure. The resulting solid was recrystalized in EtOAc:MeOH (2:1) (40 mL/gram). The solution was left to cool to RT and kept in fridge overnight. The crystal formed was filtered and dried under high vacuum to afford product $\mathbf{2 g}$ (354 $\mathrm{mg}, 0.932 \mathrm{mmol}$, 42\% yield) as colorless crystals.

${ }^{1} \mathrm{H}$ NMR $\left(400 \mathrm{MHz}, \mathrm{CDCl}_{3}\right) \delta 8.23(\mathrm{~d}, J=2.1 \mathrm{~Hz}, 1 \mathrm{H}, \mathrm{ArH}), 8.05(\mathrm{~d}, J=8.5 \mathrm{~Hz}, 1 \mathrm{H}, \mathrm{ArH}), 7.58(\mathrm{dd}$, $J=8.6,2.2 \mathrm{~Hz}, 1 \mathrm{H}, \operatorname{ArH}), 7.45-7.35(\mathrm{~m}, 2 \mathrm{H}, \operatorname{ArH}), 7.30-7.26(\mathrm{~m}, 1 \mathrm{H}, \operatorname{ArH}), 7.24-7.15(\mathrm{~m}, 1 \mathrm{H}$, $\mathrm{ArH}), 2.51\left(\mathrm{~s}, 3 \mathrm{H}, \mathrm{ArCH}_{3}\right)$.

${ }^{13} \mathrm{C}$ NMR $\left(101 \mathrm{MHz}, \mathrm{CDCl}_{3}\right) \delta$ 166.7, 162.3 (d, $\left.J=248.6 \mathrm{~Hz}\right), 142.7,136.0,133.2,131.0,130.5$ (d, J = 8.5 Hz), 128.7 (d, J = 3.3 Hz), 125.9, 122.4 (d, J = 9.4 Hz), 119.6 (d, J = $23.2 \mathrm{~Hz}$ ), 118.2 (d, $J=21.2 \mathrm{~Hz}), 112.3,104.4(3.3 \mathrm{~Hz}), 51.8,20.8$.

HRMS (ESI/QTOF) m/z: [M + H] ${ }^{+}$Calcd for $\mathrm{C}_{16} \mathrm{H}_{11} \mathrm{FIO}_{2}{ }^{+}$380.9782; Found 380.9784 . 


\section{Synthesis of $2 \mathrm{~h}$}

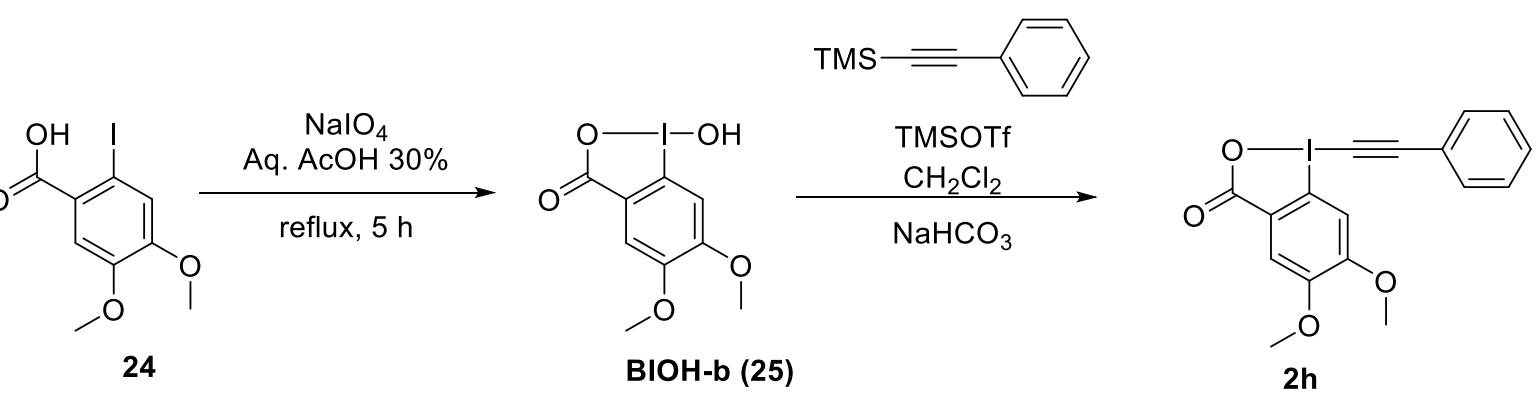

$\mathrm{NaIO}_{4}$ (1.25 g, 5.84 mmol, 1.05 equiv) and 2-iodo 4,5-dimethoxybenzoic acid (24) (1.71 g, 5.56 mmol, 1.00 equiv) were suspended in $30 \%$ (v:v) aq. $\mathrm{AcOH}(15 \mathrm{~mL})$. The mixture was vigorously stirred and refluxed for $4 \mathrm{~h}$. The reaction mixture was then diluted with cold water $(40 \mathrm{~mL})$ and allowed to cool to RT, protecting it from light. The crude product was collected by filtration, washed on the filter with ice water $(3 \times 4 \mathrm{~mL})$ and acetone $(3 \times 4 \mathrm{~mL})$, and air-dried in the dark to give the pure product BIOH-b (25) $(1.51 \mathrm{~g}, 4.67 \mathrm{mmol}, 84 \%)$ as a colorless solid.

Following reported procedure, ${ }^{12}$ trimethylsilyl triflate ( $400 \mu \mathrm{L}, 2.20 \mathrm{mmol}, 1.10$ equiv) was added to a suspension of BIOH-b (25) (648 mg, 2.00 mmol, 1.00 equiv) in $\mathrm{CH}_{2} \mathrm{Cl}_{2}(10 \mathrm{~mL}$ ) at RT. The resulting yellow mixture was stirred for $1 \mathrm{~h}$, followed by the dropwise addition of trimethyl(phenylethynyl)silane ( $430 \mu \mathrm{L}, 2.20 \mathrm{mmol}, 1.10$ equiv). The resulting suspension was stirred for $6 \mathrm{~h}$ at RT, during this time a yellow suspension was formed. A saturated solution of $\mathrm{NaHCO}_{3}(10 \mathrm{~mL})$ was then added. The two layers were separated and the aqueous layer was extracted with DCM (10 mL). The combined organic extracts were dried over $\mathrm{MgSO}_{4}$, filtered and evaporated under reduced pressure. The resulting solid was recrystallized in $\mathrm{CH}_{3} \mathrm{CN}$ (50 $\mathrm{mL}$ ) and a few EtOH to afford $\mathbf{2 h}$ (306 $\mathrm{mg}, 0.752 \mathrm{mmol}, 38 \%$ ) as a colorless solid.

${ }^{1}{ }_{\text {H NMR }}\left(400 \mathrm{MHz}, \mathrm{CDCl}_{3}\right) \delta 7.89(\mathrm{~s}, 1 \mathrm{H}, \mathrm{ArH}), 7.70(\mathrm{~s}, 1 \mathrm{H}, \mathrm{ArH}), 7.60(\mathrm{~m}, 2 \mathrm{H}, \mathrm{ArH}), 7.50(\mathrm{~m}$, $3 \mathrm{H}, \mathrm{ArH}), 4.05\left(\mathrm{~s}, 3 \mathrm{H}, \mathrm{OCH}_{3}\right), 3.98\left(\mathrm{~s}, 3 \mathrm{H} ; \mathrm{OCH}_{3}\right) .{ }^{13} \mathrm{C} \mathrm{NMR}(101 \mathrm{MHz}, \mathrm{CDCl} 3) \delta 166.8,154.9$, 152.2 , 132.6, 130.8, 128.9, 124.4, 120.5, 113.3, 107.6, 106.3, 105.3, 56.7, 56.4, 51.2. Consistent with reported data. ${ }^{12}$ 


\section{1-[4-Pentylphenylethynyl]-1,2-benziodoxol-3(1H)-one (2i)}<smiles>O=C(O)c1ccccc1I</smiles>

15

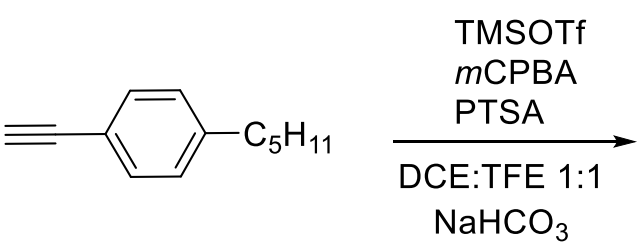

26

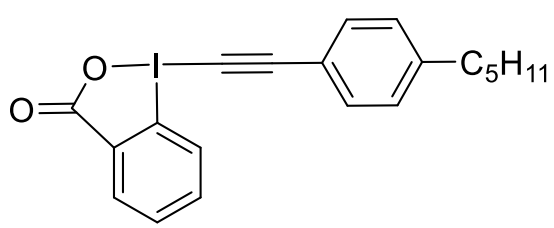

$2 \mathbf{i}$

Following a reported procedure, ${ }^{11}$ in a sealed tube, 2-iodobenzoic acid (16) $(1.00 \mathrm{~g}, 4.03$ mmol, 1.00 equiv), 4-methylbenzenesulfonic acid (775 mg, $4.03 \mathrm{mmol}, 1.00$ equiv) and mCPBA (994 mg, $4.44 \mathrm{mmol}, 1.10$ equiv) were suspended in DCE:TFE 1:1 (12 mL) and stirred for $1 \mathrm{~h}$ at $55^{\circ} \mathrm{C}$. After $1 \mathrm{~h}$, 1-ethynyl-4-pentylbenzene (26) $(1.1 \mathrm{~mL}, 5.6 \mathrm{mmol}, 1.4$ equiv) was added and the reaction was stirred at $55^{\circ} \mathrm{C}$ for $24 \mathrm{~h}$. After $24 \mathrm{~h}$, the solvent was evaporated and the residue was redissolved in $\mathrm{CH}_{2} \mathrm{Cl}_{2}\left(20 \mathrm{~mL}\right.$ ) and stirred vigorously with $\mathrm{NaHCO}_{3}$ sat. (30 $\mathrm{mL}$ ). After $1 \mathrm{~h}$, the reaction mixture was transferred into a separating funnel and the layers were separated. The aqueous layer was extracted with $\mathrm{CH}_{2} \mathrm{Cl}_{2}(2 \times 50 \mathrm{~mL})$. The combined organic layers were washed with sat. $\mathrm{NaHCO}_{3}$, dried over $\mathrm{MgSO}$, filtered and concentrated under vacuum. The resulting solid was boiled in $\mathrm{MeCN}(20 \mathrm{~mL})$, then filtered and the collected solid was further purified by column chromatography using pure ethyl acetate. Trituration in pentane afforded $\mathbf{2 i}$ (176 mg, $0.421 \mathrm{mmol}, 10 \%)$ as a pale yellow solid. ${ }^{1} \mathbf{H}$ NMR $(400 \mathrm{MHz}$, Chloroform-d) $\delta 8.45-8.40(m, 1 \mathrm{H}, \mathrm{ArH}), 8.28-8.21(\mathrm{~m}, 1 \mathrm{H}, \mathrm{ArH}), 7.79-7.74(\mathrm{~m}, 2 \mathrm{H}, \operatorname{ArH})$, $7.56-7.48(\mathrm{~m}, 2 \mathrm{H}, \mathrm{ArH}), 7.26-7.23(\mathrm{~m}, 2 \mathrm{H}, \mathrm{ArH}), 2.71-2.60\left(\mathrm{~m}, 2 \mathrm{H}, \mathrm{ArCH}_{2}\right), 1.69-1.54(\mathrm{~m}$, $2 \mathrm{H}, \mathrm{ArCH}_{2} \mathrm{CH}_{2}$ ), $1.40-1.27\left(\mathrm{~m}, 4 \mathrm{H}, \mathrm{CH}_{2} \mathrm{CH}_{2} \mathrm{CH} 3\right), 0.90\left(\mathrm{t}, J=6.8 \mathrm{~Hz}, 3 \mathrm{H}, \mathrm{CH}_{2} \mathrm{CH}_{3}\right) .{ }^{13} \mathrm{C}$ NMR (101 $\mathrm{MHz}$, Chloroform-d) $\delta$ 166.6, 146.7, 135.0, 133.0, 132.6, 131.7, 131.5, 129.0, 126.3, 117.7, $116.4,107.4,49.4,36.2,31.5,31.0,22.6,14.1$. Consistent with reported data. ${ }^{11}$ 


\section{1-[4-Bromophenylethynyl]-1,2-benziodoxol-3(1H)-one (2j)}<smiles>O=C1OI(O)c2ccccc21</smiles>

16<smiles>CSC#Cc1ccc(Br)cc1</smiles>

27

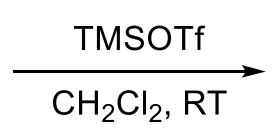

7

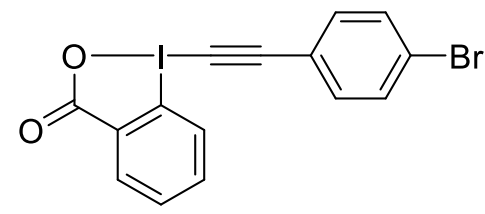

2j

Following reported procedure, ${ }^{7}$ Trimethylsilyl triflate $(1.0 \mathrm{~mL}, 5.5 \mathrm{mmol}, 1.1$ equiv) was added to a suspension of 2-iodosylbenzoic acid (16) (1.3 g, $5.0 \mathrm{mmol}, 1.0$ equiv) in $\mathrm{CH}_{2} \mathrm{Cl}_{2}(15 \mathrm{~mL})$ at RT The resulting suspension was stirred for $1 \mathrm{~h}$, followed by the dropwise addition of ((4 bromophenyl)ethynyl)trimethylsilane (27) (1.39 g, $5.5 \mathrm{mmol}, 1.1$ equiv), which was dissolved in $\mathrm{CH}_{2} \mathrm{Cl}_{2}(1 \mathrm{~mL})$. The resulting suspension was stirred for $6 \mathrm{~h}$ at RT A saturated solution of $\mathrm{NaHCO}_{3}(20 \mathrm{~mL})$ was then added and the mixture was stirred vigorously for $30 \mathrm{~min}$, the two layers were separated and the organic layer was washed with sat. The mixture was extracted with $\mathrm{H}_{2} \mathrm{O}$ and $\mathrm{DCM}(3 \times 20 \mathrm{~mL})$, washed with brine, then dried over $\mathrm{Na}_{2} \mathrm{SO}_{4}$, filtered and evaporated under reduced pressure. The resulting solid was recrystalized in EtOAc:MeOH (2:1) (40 mL/gram). The solution was left to cool to RT overnight. The crystal formed was filtered and dried under high vacuum to afford product $2 \mathrm{j}$ ( $1.35 \mathrm{~g}, 3.15 \mathrm{mmol}, 63 \%$ yield) as a pale yellow solid. ${ }^{1} \mathbf{H}$ NMR $\left(400 \mathrm{MHz}, \mathrm{CDCl}_{3}\right) \delta 8.51-8.30(\mathrm{~m}, 1 \mathrm{H}, \mathrm{ArH}), 8.30-8.13(\mathrm{~m}, 1 \mathrm{H}$, $\operatorname{ArH}), 7.84-7.72(\mathrm{~m}, 2 \mathrm{H}, \operatorname{ArH}), 7.58(\mathrm{~d}, 2 \mathrm{H}, J=8.5 \mathrm{~Hz}, \operatorname{ArH}), 7.46(\mathrm{~d}, 2 \mathrm{H}, J=8.5 \mathrm{~Hz}, \operatorname{ArH}) .{ }^{13} \mathrm{C}$ NMR $\left(101 \mathrm{MHz} \mathrm{CDCl}_{3}\right) \delta$ 166.6, 135.1, 134.3, 132.7, 132.3, 131.9, 131.4, 126.3, 125.7, 119.6, $116.3,105.4,52.1$. Consistent with reported data. ${ }^{7}$

\section{1-[2-Bromophenylethynyl]-1,2-benziodoxol-3(1H)-one (2k)}<smiles>O=C1OI(O)c2ccccc21</smiles>

16

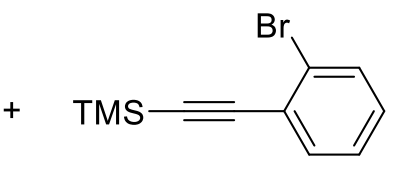

28

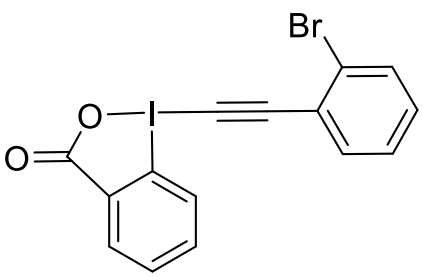

2k

Following reported procedure, ${ }^{7}$ trimethylsilyl triflate $(0.42 \mathrm{~mL}, 2.4 \mathrm{mmol}, 1.1$ equiv) was added to a suspension of $\mathrm{BIOH}(16)\left(0.562 \mathrm{~g}, 2.13 \mathrm{mmol}, 1.00\right.$ equiv) in $\mathrm{CH}_{2} \mathrm{Cl}_{2}(6 \mathrm{~mL})$ at RT The resulting suspension was stirred for $1 \mathrm{~h}$, followed by the drop wise addition of ((2bromophenyl)ethynyl)trimethylsilane (28) (0.61 g, $2.4 \mathrm{mmol}, 1.1 \mathrm{gquiv})$. The resulting 
suspension was stirred for $6 \mathrm{~h}$ at RT. A saturated solution of $\mathrm{NaHCO}_{3}(10 \mathrm{~mL})$ was then added and the mixture was stirred vigorously for $1 \mathrm{~h}$ resulting in a persistent emulsion/suspension. The mixture was diluted with $\mathrm{CHCl}_{3}(10 \mathrm{~mL})$, water $(5 \mathrm{~mL})$ and $\mathrm{MeOH}$ (ca. $2 \mathrm{~mL}$ ) to afford 2 distinct layers. The two layers were separated, and the organic layer was washed with sat. $\mathrm{NaHCO}_{3}(5 \mathrm{~mL})$, dried over $\mathrm{Na}_{2} \mathrm{SO}_{4}$, filtered, and evaporated under reduced pressure. The resulting solid was recrystallized in EtOAc:MeOH (7:3 v:v) (ca. $20 \mathrm{~mL}$ ). The solution was left to cool to RT then was placed in the freezer $\left(-20^{\circ} \mathrm{C}\right)$ overnight. The crystals were filtered and washed with $\mathrm{Et}_{2} \mathrm{O}$ affording $\mathbf{2 k}$ ( $465 \mathrm{mg}, 1.09 \mathrm{mmol}, 51 \%$ yield) as colorless crystals. ${ }^{1} \mathbf{H}$ NMR $\left(400 \mathrm{MHz}, \mathrm{CDCl}_{3}\right) \delta 8.44(\mathrm{td}, \mathrm{J}=7.3,2.1 \mathrm{~Hz}, 2 \mathrm{H}, \operatorname{ArH}), 7.84-7.74(\mathrm{~m}, 2 \mathrm{H}, \operatorname{ArH}), 7.68(\mathrm{~d}, \mathrm{~J}=1.1$ $\mathrm{Hz}, 1 \mathrm{H}, \mathrm{ArH}), 7.61$ (dd, J = 7.6, $1.7 \mathrm{~Hz}, 1 \mathrm{H}, \mathrm{ArH}), 7.36(\mathrm{~m}, 2 \mathrm{H}, \mathrm{ArH}) .{ }^{13} \mathrm{C} \mathrm{NMR}\left(101 \mathrm{MHz}, \mathrm{CDCl}_{3}\right)$ $7 \delta$ 166.6, 135.2, 134.7, 133.0, 132.7 , 131.8, 131.3, 127.6, 126.8, 126.4, 123.2, 116.5, 104.3, 55.4. (One carbon is not resolved). Consistent with reported data. ${ }^{7}$ 


\section{Optimization}

In a $12 * 75 \mathrm{~mm}$ Borosilicate glass tube, PhEBX $2 \mathrm{a}$ was added. The tube was then closed with a rubber septum and sealed off with parafilm. Three cycles of evacuate-refill with nitrogen were performed to remove $\mathrm{O}_{2}$ and $\mathrm{CHCl}_{3}(0.1 \mathrm{M})$ was added, followed by the addition of $1 \mathrm{a}$. The reaction mixture was stirred at room temperature with Kessil lamps (440 nm). It should be noted that chloroform can be used from commercially sealed-cap bottle under inert atmosphere or it is recommended to conduct three cycles of Freeze-Pump-Thaw for other sources of chloroform before use. The reaction was monitored by NMR with $\mathrm{CH}_{2} \mathrm{Br}_{2}$ as internal standard. NMR yield was determined by integration of $\mathrm{ArCH}$ NMR of products.

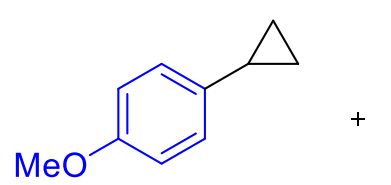

$1 \mathrm{a}$

$0.2 \mathrm{mmol}$ 1 equiv.

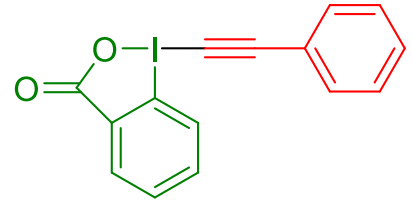

2a

2.5 equiv.

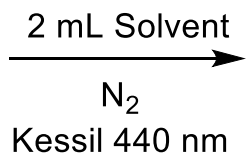

$24 \mathrm{~h}$

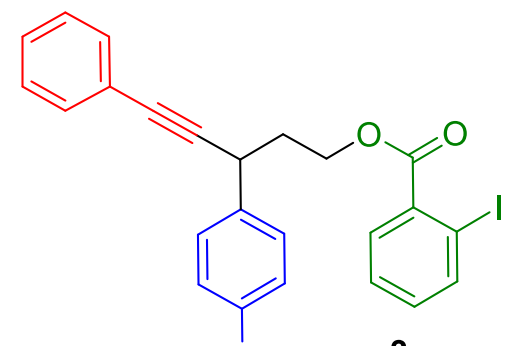

$3 a$

\begin{tabular}{|c|c|c|c|}
\hline Entry & Variation from standard condition & Conversion (\%) & NMR yield (\%) \\
\hline 1 & $\mathrm{CHCl}_{3}$ & 100 & 72 \\
\hline 2 & DCE & 62 & 20 \\
\hline 3 & $\mathrm{MeOH}$ & 64 & 12 \\
\hline 4 & $\mathrm{CH}_{3} \mathrm{CN} /$ EtOAC & $42 / 19$ & $5 / 3$ \\
\hline 5 & DMSO or THF & $<5$ & 0 \\
\hline 8 & $4 \mathrm{~mL} \mathrm{CHCl}_{3}$ & 100 & 50 \\
\hline 9 & $1 \mathrm{~mL} \mathrm{CHCl}_{3}$ & 84 & 63 \\
\hline 10 & $\mathrm{CHCl}_{3}$, only $1 \mathrm{a}$ without $2 \mathrm{a}$ & 0 & 0 \\
\hline 11 & $\mathrm{CHCl}_{3}$, with 1.5 equiv of $\mathrm{BIOH}$ & 100 & 63 \\
\hline 12 & $\mathrm{CHCl}_{3}$, with 1.5 equiv of $\mathrm{K}_{2} \mathrm{CO}_{3}$ & 58 & 24 \\
\hline
\end{tabular}




\section{Synthesis of alkynylated products}

\section{General Procedure B (GP B):}

In a $12 * 75 \mathrm{~mm}$ Borosilicate glass tube, aryl ethynyl benziodoxolone $(0.5 \mathrm{mmol}, 2.5$ equiv) was added. The tube was then closed with a rubber septum and sealed off with parafilm. Three cycle of evacuate-refill with nitrogen were performed to remove $\mathrm{O}_{2}$ and $\mathrm{CHCl}_{3}(2.0 \mathrm{~mL}, 0.1 \mathrm{M})$ was added, followed by the addition of starting material $(0.2 \mathrm{mmol})$. The reaction mixture was stirred at room temperature with Kessil lamps (440 nm). It should be noted that chloroform can be used from commercially sealed-cap bottle under inert atmosphere or it is recommended to conduct three cycle of Freeze-Pump-Thaw for other sources of chloroform before use. The reaction was monitored by NMR with $\mathrm{CH}_{2} \mathrm{Br}_{2}$ as internal standard. Upon completion by either full conversion of starting material or hypervalent iodine reagents, the mixture was concentrated in vacuo and purified by on Biotage (Büchi flashpure cartridge 25 g) to obtained the product. 


\section{3-(4-Methoxyphenyl)-5-phenylpent-4-yn-1-yl 2-iodobenzoate (3a)}<smiles>COc1ccc(C(C#Cc2ccccc2)CCOC(=O)c2ccccc2I)cc1</smiles>

Following the general procedure B, starting from phenyl ethynyl benziodoxolone (2a) (174 mg, $500 \mu \mathrm{mol}, 2.50$ equiv) and 1-cyclopropyl-4-methoxybenzene (1a) (29.6 mg, $200 \mu \mathrm{mol}$, 1.00 equiv). The crude mixture was purified by column chromatography on Biotage (Büchi flashpure cartridge $25 \mathrm{~g}$, gradient of Pentane:EtOAc from 5:95 to 88:12) affording 3-(4methoxyphenyl)-5-phenylpent-4-yn-1-yl 2-iodobenzoate (3a) (67.5 mg, $136 \mu \mathrm{mol}, 68 \%$ yield) as pale yellow oil.

$\mathbf{R f}=0.29\left(\mathrm{SiO}_{2}, 20: 1\right.$ Pentane/ethyl acetate $)$.

${ }^{1} \mathrm{H}$ NMR $\left(400 \mathrm{MHz}, \mathrm{CDCl}_{3}\right) \delta 7.99(\mathrm{~d}, J=7.9 \mathrm{~Hz}, 1 \mathrm{H}, \operatorname{ArH}), 7.77(\mathrm{dd}, J=7.7,1.9 \mathrm{~Hz}, 1 \mathrm{H}, \operatorname{ArH})$, $7.44(\mathrm{td}, J=4.3,1.7 \mathrm{~Hz}, 2 \mathrm{H}, \operatorname{ArH}), 7.40-7.34(\mathrm{~m}, 3 \mathrm{H}, \mathrm{ArH}), 7.32-7.27(\mathrm{~m}, 3 \mathrm{H}, \mathrm{ArH}), 7.15(\mathrm{t}, J$ $=7.7 \mathrm{~Hz}, 1 \mathrm{H}, \mathrm{ArH}), 6.92-6.86(\mathrm{~m}, 2 \mathrm{H}, \mathrm{ArH}), 4.57\left(\mathrm{dt}, \mathrm{J}=12.7,6.6 \mathrm{~Hz}, 1 \mathrm{H}, \mathrm{OCH}_{2} \mathrm{CH}_{2}\right), 4.48(\mathrm{dt}$, $\left.J=11.3,5.8 \mathrm{~Hz}, 1 \mathrm{H}, \mathrm{OCH}_{2} \mathrm{CH}_{2}\right), 4.11\left(\mathrm{t}, J=7.4 \mathrm{~Hz}, 1 \mathrm{H}, \mathrm{CHCH}_{2}\right), 3.81\left(\mathrm{~s}, 3 \mathrm{H}, \mathrm{OCH}_{3}\right), 2.29(\mathrm{q}, J=$ $6.8 \mathrm{~Hz}, 2 \mathrm{H}, \mathrm{OCH}_{2} \mathrm{CH}_{2}$ ).

${ }^{13} \mathrm{C}$ NMR (101 MHz, CDCl 3 ) $\delta$ 166.6, 158.8, 141.4, 135.4, 133.2, 132.8, 131.8, 131.2, 128.6, $128.4,128.1,128.0,123.5,114.2,94.2,90.5,84.0,63.8,55.5,37.3,34.7$.

IR ( $\left.\boldsymbol{v}_{\max }, \mathbf{c m}^{-1}\right) 2923(\mathrm{~m}), 2852(\mathrm{w}), 2358(\mathrm{w}), 1727(\mathrm{~s}), 1677(\mathrm{~m}), 1601(\mathrm{~s}), 1462(\mathrm{~m}), 1292(\mathrm{~s})$, $1250(\mathrm{~s}), 1173(\mathrm{~m}), 743(\mathrm{~m})$.

HRMS (APCI/QTOF) m/z: [M + H] $]^{+}$Calcd for $\mathrm{C}_{25} \mathrm{H}_{22} \mathrm{IO}_{3}{ }^{+} 497.0608$; Found 497.0604 . 


\section{3-(2-Methoxyphenyl)-5-phenylpent-4-yn-1-yl 2-iodobenzoate (3b)}<smiles>COc1ccccc1C(C#Cc1ccccc1)CCOC(=O)c1ccccc1I</smiles>

Following the general procedure B, starting from 1-cyclopropyl-2-methoxybenzene (1) (29.6 $\mathrm{mg}, 200 \mu \mathrm{mol}, 1.00$ equiv) and phenyl ethynyl benziodoxolone (2a) (174 mg, $500 \mu \mathrm{mol}, 2.50$ equiv), The crude mixture was purified by column chromatography on Biotage (Büchi flashpure cartridge $25 \mathrm{~g}$, gradient of Pentane:EtOAc from 2:98 to 90:10) affording 3-(2methoxyphenyl)-5-phenylpent-4-yn-1-yl 2-iodobenzoate (3b) (64.7 mg, $130 \mu \mathrm{mol}, 65 \%$ yield) as colorless oil.

$\mathbf{R f}=0.59\left(\mathrm{SiO}_{2}, 10: 1\right.$ Pentane/ethyl acetate $)$.

${ }^{1} \mathrm{H}$ NMR $\left(400 \mathrm{MHz}, \mathrm{CDCl}_{3}\right) \delta 7.95$ (dd, $\left.J=8.0,1.2 \mathrm{~Hz}, 1 \mathrm{H}, \mathrm{ArH}\right), 7.79$ (dd, $J=7.8,1.7 \mathrm{~Hz}, 1 \mathrm{H}$, $\operatorname{ArH}), 7.62(\mathrm{dd}, J=7.6,1.8 \mathrm{~Hz}, 1 \mathrm{H}, \operatorname{ArH}), 7.44-7.38(\mathrm{~m}, 2 \mathrm{H}, \operatorname{ArH}), 7.31(\mathrm{td}, J=7.6,1.2 \mathrm{~Hz}, 1 \mathrm{H}$, $\operatorname{ArH}), 7.27-7.18(\mathrm{~m}, 4 \mathrm{H}, \mathrm{ArH}), 7.09(\mathrm{td}, J=7.6,1.8 \mathrm{~Hz}, 1 \mathrm{H}, \mathrm{ArH}), 6.95(\mathrm{td}, J=7.5,1.1 \mathrm{~Hz}, 1 \mathrm{H}$, $\operatorname{ArH}), 6.83(\mathrm{dd}, J=8.2,1.1 \mathrm{~Hz}, 1 \mathrm{H}, \mathrm{ArH}), 4.56\left(\mathrm{dd}, J=8.7,5.3 \mathrm{~Hz}, 1 \mathrm{H}, \mathrm{CHCH}_{2}\right), 4.53-4.43(\mathrm{~m}$, $2 \mathrm{H}, \mathrm{OCH}_{2} \mathrm{CH}_{2}$ ), 3.78 (s, 3H, OCH3), 2.31 (dtd, $J=14.0,7.0,5.3 \mathrm{~Hz}, 1 \mathrm{H}, \mathrm{OCH}_{2} \mathrm{CH}_{2}$ ), 2.17 (ddt, $J=$ $14.3,8.8,5.8 \mathrm{~Hz}, 1 \mathrm{H}, \mathrm{OCH}_{2} \mathrm{CH}_{2}$ ).

${ }^{13} \mathrm{C}$ NMR $\left(101 \mathrm{MHz}, \mathrm{CDCl}_{3}\right) \delta$ 166.4, 156.3, 141.5, 135.1, 132.7, 131.8, 131.3, 129.4, 128.7, 128.4, 128.3, 128.3, 128.0, 123.7, 121.0, 110.6, 94.3, 90.7, 83.5, 64.1, 55.5, 35.5, 29.0.

IR $\left(v_{\text {max }}, \mathrm{cm}^{-1}\right) 2925(\mathrm{w}), 2237(\mathrm{~m}), 1496(\mathrm{~s}), 1487(\mathrm{~m}), 1302(\mathrm{~m}), 1255(\mathrm{~m}), 1234(\mathrm{~m}), 1207(\mathrm{~s})$, $1127(\mathrm{~m}), 1114(\mathrm{~m}), 1108(\mathrm{~m}), 1056$ (s), 1046 (m), 755 (s).

HRMS (ESI/QTOF) m/z: [M + Na] ${ }^{+}$Calcd for $\mathrm{C}_{25} \mathrm{H}_{21} \mathrm{INaO}_{3}{ }^{+}$519.0428; Found 519.0429. 


\section{3-(4-Ethoxyphenyl)-5-phenylpent-4-yn-1-yl 2-iodobenzoate (3c)}<smiles>CCOc1ccc(C(C#Cc2ccccc2)CCOC(=O)c2ccccc2I)cc1</smiles>

Following the general procedure C, starting from 1-cyclopropyl-4-ethoxybenzene (1c) (32.4 $\mathrm{mg}, 200 \mu \mathrm{mol}, 1.00$ equiv) and phenyl ethynyl benziodoxolone (2a) (174 mg, $500 \mu \mathrm{mol}, 2.50$ equiv.). The crude mixture was purified by column chromatography on Biotage (Büchi flashpure cartridge $25 \mathrm{~g}$, gradient of Pentane:EtOAc from 98:2 to 90:10, affording 3-(4ethoxyphenyl)-5-phenylpent-4-yn-1-yl 2-iodobenzoate (3c) (54.1 mg, $103 \mu \mathrm{mol}, 51 \%$ yield) as pale yellow oil.

$\mathbf{R f}=0.27\left(\mathrm{SiO}_{2}, 20: 1\right.$ Pentane/ethyl acetate $)$.

${ }^{1} \mathrm{H}$ NMR $\left(400 \mathrm{MHz}, \mathrm{CDCl}_{3}\right) \delta 7.99(\mathrm{~d}, J=7.9 \mathrm{~Hz}, 1 \mathrm{H}, \mathrm{ArH}), 7.77(\mathrm{dd}, J=7.8,1.7 \mathrm{~Hz}, 1 \mathrm{H}, \operatorname{ArH})$, $7.44(\mathrm{dd}, J=6.7,3.0 \mathrm{~Hz}, 2 \mathrm{H}, \mathrm{ArH}), 7.40-7.33(\mathrm{~m}, 3 \mathrm{H}, \mathrm{ArH}), 7.33-7.27(\mathrm{~m}, 3 \mathrm{H}, \mathrm{ArH}), 7.15(\mathrm{td}$, $J=7.7,1.7 \mathrm{~Hz}, 1 \mathrm{H}, \mathrm{ArH}), 6.88(\mathrm{~d}, J=8.5 \mathrm{~Hz}, 2 \mathrm{H}, \mathrm{ArH}), 4.56\left(\mathrm{dt}, J=11.1,6.6 \mathrm{~Hz}, 1 \mathrm{H}, \mathrm{OCH}_{2} \mathrm{CH}_{2} \mathrm{CH}\right)$, $4.48\left(\mathrm{dt}, J=11.4,5.9 \mathrm{~Hz}, 1 \mathrm{H}, \mathrm{OCH}_{2} \mathrm{CH}_{2} \mathrm{CH}\right), 4.10\left(\mathrm{t}, J=7.4 \mathrm{~Hz}, 1 \mathrm{H}, \mathrm{CCCHCH}_{2}\right), 4.02(\mathrm{q}, J=7.0$ $\left.\mathrm{Hz}, 2 \mathrm{H}, \mathrm{OCH}_{2} \mathrm{CH}_{3}\right), 2.36-2.20\left(\mathrm{~m}, 2 \mathrm{H}, \mathrm{OCH}_{2} \mathrm{CH}_{2} \mathrm{CH}\right), 1.41\left(\mathrm{t}, \mathrm{J}=7.0 \mathrm{~Hz}, 3 \mathrm{H}, \mathrm{OCH}_{2} \mathrm{CH}_{3}\right)$.

${ }^{13} \mathrm{C}$ NMR $\left(101 \mathrm{MHz}, \mathrm{CDCl}_{3}\right) \delta 166.6,158.2,141.4,135.4,133.0,132.8,131.8,131.2,128.6$, $128.4,128.1,128.0,123.6,114.8,94.2,90.6,84.0,63.8,63.6,37.4,34.7,15.0$.

IR $\left(v_{\max }, \mathrm{cm}^{-1}\right) 2957(\mathrm{w}), 2924(\mathrm{~m}), 2227(\mathrm{w}), 1725$ (s), $1713(\mathrm{~m}), 1508(\mathrm{~m}), 1289(\mathrm{~s}), 1247(\mathrm{~s})$, $1205(\mathrm{~m}), 1133(\mathrm{~m}), 1043(\mathrm{~m}), 1013(\mathrm{~m}), 758(\mathrm{~m}), 741(\mathrm{~m})$.

HRMS (ESI/QTOF) m/z: [M + Na] ${ }^{+}$Calcd for $\mathrm{C}_{26} \mathrm{H}_{23} \mathrm{INaO}_{3}{ }^{+}$533.0584; Found 533.0591. 


\section{3-(4-(tert-butyl)phenyl)-5-phenylpent-4-yn-1-yl 2-iodobenzoate (3d)}

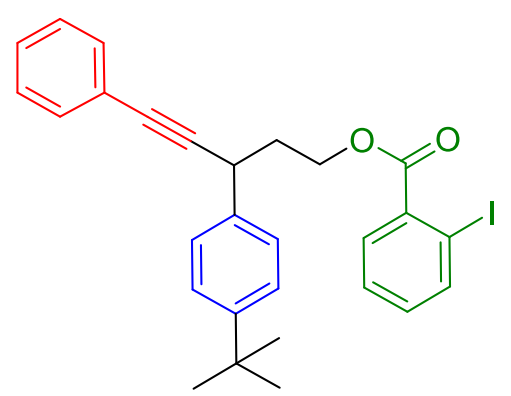

Following the general procedure B, starting from 1-tert-butyl-4-cyclopropylbenzene (1d) (34.9 mg, $200 \mu \mathrm{mol}, 1.00$ equiv), phenyl ethynyl benziodoxolone (2a) (139 mg, $400 \mu \mathrm{mol}, 2.00$ equiv) and 10-phenyl-9-(2,4,6-trimethylphenyl)acridin-10-ium tetrafluoroborate $(1.85 \mathrm{mg}$, $4.00 \mu \mathrm{mol}, 0.0200$ equiv) under kessil lamp $467 \mathrm{~nm}$. The crude mixture was purified by column chromatography on Biotage (Büchi flashpure cartridge 25 g, gradient of Pentane:EtOAc from 99:1 to 92:8) affording 3-(4-(tert-butyl)phenyl)-5-phenylpent-4-yn-1-yl 2-iodobenzoate (3d) (53.2 mg, $102 \mu \mathrm{mol}, 51 \%$ yield) as pale yellow oil.

$\mathbf{R}_{\mathbf{f}}: 0.55$ ( $\mathrm{SiO}_{2}, 20: 1$ Pentane/ethyl acetate).

${ }^{1} \mathrm{H}$ NMR $\left(400 \mathrm{MHz}, \mathrm{CDCl}_{3}\right) \delta 8.00$ (dd, $\left.J=7.9,1.2 \mathrm{~Hz}, 1 \mathrm{H}, \mathrm{ArH}\right), 7.81$ (dd, $J=7.8,1.7 \mathrm{~Hz}, 1 \mathrm{H}$, $\operatorname{ArH}), 7.48-7.44(\mathrm{~m}, 2 \mathrm{H}, \mathrm{ArH}), 7.41-7.36(\mathrm{~m}, 5 \mathrm{H}, \mathrm{ArH}), 7.33-7.27(\mathrm{~m}, 3 \mathrm{H}, \mathrm{ArH}), 7.15(\mathrm{td}, J=$ 7.7, $1.7 \mathrm{~Hz}, 1 \mathrm{H}, \mathrm{ArH}), 4.60\left(\mathrm{ddd}, J=11.1,7.4,6.1 \mathrm{~Hz}, 1 \mathrm{H}, \mathrm{OCH}_{2} \mathrm{CH}_{2}\right), 4.51(\mathrm{dt}, J=11.4,5.9 \mathrm{~Hz}$, $\left.1 \mathrm{H}, \mathrm{OCH}_{2} \mathrm{CH}_{2}\right), 4.18-4.11\left(\mathrm{~m}, 1 \mathrm{H}, \mathrm{CHCH}_{2}\right), 2.40-2.24\left(\mathrm{~m}, 2 \mathrm{H}, \mathrm{OCH}_{2} \mathrm{CH}_{2}\right), 1.33\left(\mathrm{~s}, 9 \mathrm{H}, \mathrm{C}\left(\mathrm{CH}_{3}\right)_{3}\right)$. ${ }^{13} \mathrm{C}$ NMR $\left(101 \mathrm{MHz}, \mathrm{CDCl}_{3}\right) \delta 166.6,150.1,142.2,141.4,138.0,135.4,132.7,131.8,131.2$, $128.9,128.3,128.0,127.3,125.8,125.5,123.6,94.1,90.5,84.0,63.9,37.2$, 35.0, 34.6, 31.5. IR $\left(v_{\max }, \mathrm{cm}^{-1}\right) 2953(\mathrm{~m}), 2868$ (w), 2196 (w), 1711 (s), 1289 (s), 1269 (s), 1249 (s), $1228(\mathrm{~m})$, 1125 (s), 1105 (s), 1014 (s), 752 (s), 741 (s).

HRMS (ESI/QTOF) m/z: [M + H] ${ }^{+}$Calcd for $\mathrm{C}_{28} \mathrm{H}_{28} \mathrm{IO}_{2}{ }^{+}$523.1129; Found 523.1136. 


\section{3,5-Diphenylpent-4-yn-1-yl 2-iodobenzoate (3e)}

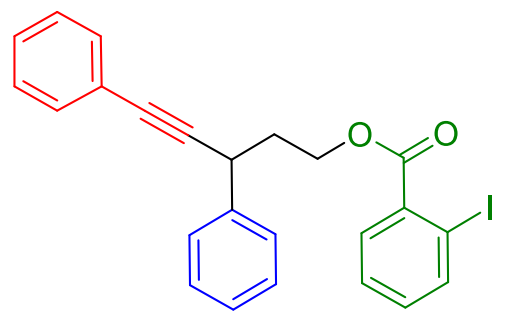

Following the general procedure B, starting from cyclopropylbenzene (1e) $(23.6 \mathrm{mg}, 200$ $\mu \mathrm{mol}, 1.00$ equiv), phenyl ethynyl benziodoxolone (2a) (139 mg, $400 \mu \mathrm{mol}, 2.00$ equiv) and 10-phenyl-9-(2,4,6-trimethylphenyl)acridin-10-ium tetrafluoroborate $(1.85 \mathrm{mg}, 4.00 \mu \mathrm{mol}$, 0.0200 equiv) under kessil lamp $467 \mathrm{~nm}$. The crude mixture was purified by column chromatography on Biotage (Büchi flashpure cartridge $25 \mathrm{~g}$, gradient of Pentane:EtOAc from 99:1 to 92:8) affording 3,5-diphenylpent-4-yn-1-yl 2-iodobenzoate (3e) (37.2 mg, $79.8 \mu \mathrm{mol}$, $40 \%$ yield) as colorless oil.

$\mathbf{R}_{\mathbf{f}}: 0.46\left(\mathrm{SiO}_{2}, 20: 1\right.$ Pentane/ethyl acetate).

${ }^{1} \mathrm{H}$ NMR $\left(400 \mathrm{MHz}, \mathrm{CDCl}_{3}\right) \delta 8.00(\mathrm{dd}, J=8.0,1.2 \mathrm{~Hz}, 1 \mathrm{H}, \mathrm{ArH}), 7.77(\mathrm{dd}, J=7.8,1.7 \mathrm{~Hz}, 1 \mathrm{H}$, $\operatorname{ArH}), 7.49(\mathrm{~d}, J=1.6 \mathrm{~Hz}, 1 \mathrm{H}, \mathrm{ArH}), 7.47-7.43$ (m, 3H, ArH), 7.37 (dddd, J = 7.8, 5.9, 4.8, 1.4 $\mathrm{Hz}, 3 \mathrm{H}, \mathrm{ArH}), 7.33-7.26(\mathrm{~m}, 4 \mathrm{H}, \mathrm{ArH}), 7.15(\mathrm{td}, J=7.6,1.7 \mathrm{~Hz}, 1 \mathrm{H}, \operatorname{ArH}), 4.59(\mathrm{ddd}, J=11.2$, 7.5, 6.0 Hz, $\left.1 \mathrm{H}, \mathrm{OCH}_{2} \mathrm{CH}_{2}\right), 4.50\left(\mathrm{dt}, J=11.3,5.9 \mathrm{~Hz}, 1 \mathrm{H}, \mathrm{OCH}_{2} \mathrm{CH}_{2}\right), 4.17(\mathrm{dd}, J=8.5,6.3 \mathrm{~Hz}, 1 \mathrm{H}$, $\left.\mathrm{CHCH}_{2}\right), 2.39-2.25\left(\mathrm{~m}, 2 \mathrm{H}, \mathrm{OCH}_{2} \mathrm{CH}_{2}\right)$.

${ }^{13} \mathrm{C}$ NMR $\left(101 \mathrm{MHz}, \mathrm{CDCl}_{3}\right):{ }^{13} \mathrm{C}$ NMR $\left(101 \mathrm{MHz}, \mathrm{CDCl}_{3}\right) \delta 166.6,141.4,141.2,135.4,132.8$, $131.8,131.2$, 128.9, 128.4, 128.1, 128.0, 127.6, 127.2, 123.5, 94.1, 90.2, 84.2, 63.8, 37.3, 35.5. IR $\left(v_{\max }, \mathrm{cm}^{-1}\right) 3061(w), 2957(w), 2198(w), 1711(s), 1706(\mathrm{~m}), 1289$ (s), 1271 (s), $1249(\mathrm{~s})$, $1231(\mathrm{~m}), 1133(\mathrm{~s}), 1102(\mathrm{~m}), 1013(\mathrm{~s}), 757(\mathrm{~s}), 741(\mathrm{~s}), 714(\mathrm{~s})$.

HRMS (ESI/QTOF) m/z: [M + Na] ${ }^{+}$Calcd for $\mathrm{C}_{24} \mathrm{H}_{19} \mathrm{INaO}_{2}{ }^{+}$489.0322; Found 489.0331. 


\section{3-(4-Methoxy-2-methylphenyl)-5-phenylpent-4-yn-1-yl 2-iodobenzoate (3f)}<smiles>COc1ccc(C(C#Cc2ccccc2)CCOC(=O)c2ccccc2I)c(C)c1</smiles>

Following the general procedure B, starting from 1-cyclopropyl-4-methoxy-2-methylbenzene (32.4 mg, $200 \mu \mathrm{mol}, 1.00$ equiv) and phenyl ethynyl benziodoxolone (174 mg, $500 \mu \mathrm{mol}, 2.50$ equiv), The crude mixture was purified by column chromatography on Biotage (Büchi flashpure cartridge $25 \mathrm{~g}$, gradient of Pentane:EtOAc from 97:3 to 90:10) affording 3-(4methoxy-2-methylphenyl)-5-phenylpent-4-yn-1-yl 2-iodobenzoate (3f) (62.3 mg, $122 \mu \mathrm{mol}$, $61 \%$ yield) as colorless oil.

$\mathbf{R f}=0.31\left(\mathrm{SiO}_{2}, 20: 1\right.$ Pentane/ethyl acetate $)$.

${ }^{1} \mathrm{H}$ NMR $\left(400 \mathrm{MHz}, \mathrm{CDCl}_{3}\right) \delta 8.00$ (dd, $\left.J=7.9,1.2 \mathrm{~Hz}, 1 \mathrm{H}, \mathrm{ArH}\right), 7.79$ (dd, $J=7.8,1.7 \mathrm{~Hz}, 1 \mathrm{H}$, $\operatorname{ArH}), 7.51(\mathrm{~d}, J=8.5 \mathrm{~Hz}, 1 \mathrm{H}, \operatorname{ArH}), 7.46-7.41(\mathrm{~m}, 2 \mathrm{H}, \operatorname{ArH}), 7.38(\mathrm{td}, J=7.6,1.2 \mathrm{~Hz}, 1 \mathrm{H}, \operatorname{ArH})$, $7.29(\mathrm{dp}, J=4.6,1.7 \mathrm{~Hz}, 3 \mathrm{H}, \mathrm{ArH}), 7.15(\mathrm{td}, J=7.6,1.7 \mathrm{~Hz}, 1 \mathrm{H}, \mathrm{ArH}), 6.78(\mathrm{dd}, J=8.5,2.8 \mathrm{~Hz}$, $1 \mathrm{H}, \mathrm{ArH}), 6.72(\mathrm{~d}, J=2.8 \mathrm{~Hz}, 1 \mathrm{H}, \mathrm{ArH}), 4.61\left(\mathrm{ddd}, J=11.1,8.0,5.7 \mathrm{~Hz}, 1 \mathrm{H}, \mathrm{OCH}_{2} \mathrm{CH}_{2}\right.$ ), 4.54 (dt, $\left.J=11.2,5.6 \mathrm{~Hz}, 1 \mathrm{H}, \mathrm{OCH}_{2} \mathrm{CH}_{2}\right), 4.27\left(\mathrm{dd}, J=9.1,5.6 \mathrm{~Hz}, 1 \mathrm{H}, \mathrm{CCCHCH}_{2}\right), 3.79\left(\mathrm{~s}, 3 \mathrm{H}, \mathrm{OCH}_{3}\right), 2.39$ (s, $3 \mathrm{H}, \mathrm{ArCH}_{3}$ ), 2.25 (dqd, J = 14.0, 8.4, $5.6 \mathrm{~Hz}, 2 \mathrm{H}, \mathrm{OCH}_{2} \mathrm{CH}_{2} \mathrm{CH}$ ).

${ }^{13} \mathrm{C}$ NMR $\left(101 \mathrm{MHz}, \mathrm{CDCl}_{3}\right) \delta 166.6,158.5,141.5,136.5,135.3,134.2,132.8,131.8,131.6$, $131.1,128.8,128.4,128.0,123.6,116.3,111.8,94.2$, 90.9, 83.4, 64.0, 55.4, 36.0, 31.4, 19.7. IR $\left(v_{\max }, \mathrm{cm}^{-1}\right) 2957(\mathrm{~m}), 2363(\mathrm{w}), 1727(\mathrm{~s}), 1721(\mathrm{~s}), 1609(\mathrm{~m}), 1582(\mathrm{~m}), 1502(\mathrm{~s}), 1288(\mathrm{~s})$, $1267(\mathrm{~m}), 1250(\mathrm{~s}), 758(\mathrm{~s}), 742(\mathrm{~s})$.

HRMS (ESI/QTOF) m/z: [M + H] ${ }^{+}$Calcd for $\mathrm{C}_{26} \mathrm{H}_{24} \mathrm{IO}_{3}{ }^{+}$511.0765; Found 511.0764. 


\section{3-(4-Fluoro-2-methoxyphenyl)-5-phenylpent-4-yn-1-yl 2-iodobenzoate (3h)}<smiles>COc1cc(F)ccc1C(C#Cc1ccccc1)CCOC(=O)c1ccccc1I</smiles>

Following the general procedure B, starting from 1-cyclopropyl-4-fluoro-2-methoxybenzene (1h) (33.2 mg, $200 \mu \mathrm{mol}, 1.00$ equiv) and phenyl ethynyl benziodoxolone (2a) (174 mg, 500 $\mu$ mol, 2.50 equiv). The crude mixture was purified by column chromatography on Biotage (Büchi flash pure cartridge $25 \mathrm{~g}$, gradient of Pentane:EtOAc from 95:5 to 88:12) affording 3(4-fluoro-2-methoxyphenyl)-5-phenylpent-4-yn-1-yl 2-iodobenzoate (3h) (47.1mg, 91.6 $\mu \mathrm{mol}, 46 \%$ yield) as pale yellow oil.

$\mathbf{R f}=0.33\left(\mathrm{SiO}_{2}, 10: 1\right.$ Pentane/ethyl acetate $)$.

${ }^{1} \mathrm{H}$ NMR $\left(400 \mathrm{MHz}, \mathrm{CDCl}_{3}\right) \delta 8.00(\mathrm{dd}, J=7.9,1.2 \mathrm{~Hz}, 1 \mathrm{H}, \mathrm{ArH}), 7.81$ (dd, $J=7.8,1.7 \mathrm{~Hz}, 1 \mathrm{H}$, $\operatorname{ArH}), 7.59(\mathrm{dd}, J=8.5,6.7 \mathrm{~Hz}, 1 \mathrm{H}, \operatorname{ArH}), 7.49-7.42(\mathrm{~m}, 2 \mathrm{H}, \operatorname{ArH}), 7.36(\mathrm{td}, J=7.6,1.2 \mathrm{~Hz}, 1 \mathrm{H}$, $\operatorname{ArH}), 7.30(\mathrm{~m}, 3 \mathrm{H}, \mathrm{ArH}), 7.14(\mathrm{td}, J=7.7,1.7 \mathrm{~Hz}, 1 \mathrm{H}, \operatorname{ArH}), 6.68(\mathrm{td}, J=8.3,2.5 \mathrm{~Hz}, 1 \mathrm{H}, \operatorname{ArH})$, $6.60(\mathrm{dd}, J=10.8,2.5 \mathrm{~Hz}, 1 \mathrm{H}, \mathrm{ArH}), 4.60-4.45\left(\mathrm{~m}, 3 \mathrm{H}, \mathrm{OCH}_{2} \mathrm{CH}_{2}\right.$ and $\left.\mathrm{CCCHCH}_{2}\right), 3.80(\mathrm{~s}, 3 \mathrm{H}$, $\left.\mathrm{OCH}_{3}\right), 2.30\left(\mathrm{~m}, 1 \mathrm{H}, \mathrm{CH}_{2} \mathrm{CH}_{2} \mathrm{CH}\right), 2.18\left(\mathrm{~m}, 1 \mathrm{H}, \mathrm{CH}_{2} \mathrm{CH}_{2} \mathrm{CH}\right)$.

${ }^{13} \mathrm{C}$ NMR $\delta 166.4,162.9$ (d, J = 245.1 Hz), 157.3 (d, J = 9.7 Hz), 141.5, 135.0, 132.8, 131.8, 131.3, 129.7, 129.5 (d, J = 9.8 Hz), 128.4, 128.0 (d, J = 17.2 Hz), 125.0 (d, J = 3.1 Hz), 123.5, 107.1 (d, $J=21.2 \mathrm{~Hz}$ ), 99.0 (d, $J=26.0 \mathrm{~Hz}), 94.4,90.4,83.6,64.0,55.8,35.5,28.7$.

${ }^{19} \mathrm{~F}$ NMR $\left(376 \mathrm{MHz}, \mathrm{CDCl}_{3}\right) \delta-113.0$.

IR $\left(v_{\max }, \mathrm{cm}^{-1}\right) 2957(w), 2843(w), 2227$ (w), 1724 (s), 1601 (s), 1496 (s), 1282 (s), 1248 (s), 1151 (s), 1133 (s), 1104 (s), 952 (s), 835 (s), 758 (s), 741 (s).

HRMS (ESI/QTOF) m/z: [M + H] ${ }^{+}$Calcd for $\mathrm{C}_{25} \mathrm{H}_{21} \mathrm{FIO}_{3}{ }^{+}$515.0514; Found 515.0527. 


\section{4-(4-Methoxyphenyl)-6-phenylhex-5-yn-2-yl 2-iodobenzoate (3i)}

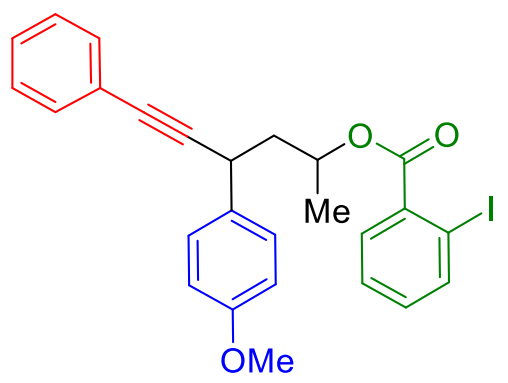

Following the general procedure B, starting from 1-methoxy-4-(2-methylcyclopropyl)benzene (1i) $(32.4 \mathrm{mg}, 200 \mu \mathrm{mol}, 1.00$ equiv) and phenyl ethynyl benziodoxolone (2a) (174 mg, 500 $\mu \mathrm{mol}, 2.50$ equiv) The crude mixture was purified by column chromatography on Biotage (Büchi flashpure cartridge $25 \mathrm{~g}$, gradient of Pentane:EtOAc from 95:5 to 90:10) affording 4-(4methoxyphenyl)-6-phenylhex-5-yn-2-yl 2-iodobenzoate (3i) as a colorless oil (mixture of two diastereomers, $71.5 \mathrm{mg}, 140 \mu \mathrm{mol}, 70 \%$ yield, $\mathrm{dr} 2: 1$, the ratio was determined by integration of the ${ }^{1} \mathrm{H}$ NMR signals for the benzylic protons $\mathrm{ArCH}$ )

$\mathbf{R f}=0.3\left(\mathrm{SiO}_{2}, 10: 1\right.$ Pentane/ethyl acetate $)$.

${ }^{1} \mathrm{H}$ NMR (400 MHz, CDCl 3 signals for major diastereomer) $\delta 7.98(\mathrm{~d}, J=7.9 \mathrm{~Hz}, 1 \mathrm{H}, \operatorname{ArH}), 7.76$ (dd, J = 7.7, 1.7 Hz, 1H, ArH), $7.48-7.43(\mathrm{~m}, 2 \mathrm{H}, \mathrm{ArH}), 7.39-7.36(\mathrm{~m}, 3 \mathrm{H}, \mathrm{ArH}), 7.29-7.27$ (m, 3H, ArH), $7.16-7.13(\mathrm{~m}, 1 \mathrm{H}, \mathrm{ArH}), 6.91-6.87(\mathrm{~m}, 2 \mathrm{H}, \operatorname{ArH}), 5.54(\mathrm{dqd}, J=9.6,6.2,3.3 \mathrm{~Hz}$, $\left.1 \mathrm{H}, \mathrm{OCH}\left(\mathrm{CH}_{3}\right) \mathrm{CH}_{2}\right), 4.10$ (dd, $J=10.5,5.0 \mathrm{~Hz}, 1 \mathrm{H}, \mathrm{CH}_{2} \mathrm{CHCC}$ ), 3.80 (s, 3H, OCH$\left.)_{3}\right), 2.27$ (ddd, $J=$ 14.5, 9.7, $\left.5.0 \mathrm{~Hz}, 1 \mathrm{H}, \mathrm{CHCH}_{2} \mathrm{CH}\left(\mathrm{CH}_{3}\right)\right), 2.10-2.05\left(\mathrm{~m}, 1 \mathrm{H}, \mathrm{CHCH}_{2} \mathrm{CH}\left(\mathrm{CH}_{3}\right)\right), 1.47(\mathrm{~d}, J=6.2 \mathrm{~Hz}$, $3 \mathrm{H}, \mathrm{OCHCH}$ ).

${ }^{13} \mathrm{C}$ NMR (101 MHz, CDCl 3 signals for major diastereomer) $\delta 166.3,158.7,141.3,136.2,133.7$, $132.5,131.9,130.8,128.7,128.5,128.3,128.0,123.6,114.2,93.9,90.4,84.2,71.5,55.4,45.0$, 34.7, 20.6.

IR $\left(v_{\max }, \mathrm{cm}^{-1}\right) 2931$ (w), 2836 (w), 2250 (w), 1726 (s), 1705 (m), 1511 (s), $1464(\mathrm{~m}), 1287$ (s), $1249(\mathrm{~s}), 1177(\mathrm{~m}), 1130$ (s), $1101(\mathrm{~m}), 1065$ (m), 1038 (s), $1014(\mathrm{~m}), 829(\mathrm{~m}), 758$ (s), $740(\mathrm{~s})$. HRMS (ESI/QTOF) m/z: [M + Na] ${ }^{+}$Calcd for $\mathrm{C}_{26} \mathrm{H}_{23} \mathrm{INaO}_{3}{ }^{+}$533.0584; Found 533.0589. 


\section{4-(4-Methoxyphenyl)-2-methyl-6-phenylhex-5-yn-2-yl 2-iodobenzoate (3j)}<smiles>[M]C(C)(CC(C#Cc1ccccc1)c1ccc(OC)cc1)OC(=O)c1ccccc1I</smiles>

Following the general procedure B, starting from 1-(2,2-dimethylcyclopropyl)-4methoxybenzene (1j) $(35.3 \mathrm{mg}, 200 \mu \mathrm{mol}, 1.00$ equiv) and phenyl ethynyl benziodoxolone (2a) (174 mg, $500 \mu \mathrm{mol}, 2.50$ equiv). The crude mixture was purified by column chromatography on Biotage (Büchi flashpure cartridge $25 \mathrm{~g}$, gradient of Pentane:EtOAc from 95:5 to 88:12) affording 4-(4-methoxyphenyl)-2-methyl-6-phenylhex-5-yn-2-yl 2iodobenzoate (3j) $(56.8 \mathrm{mg}, 108 \mu \mathrm{mol}, 54 \%$ yield) as colorless oil.

$\mathbf{R}_{\mathbf{f}}=0.33\left(\mathrm{SiO}_{2}, 20: 1\right.$ Pentane/ethyl acetate).

${ }^{1} \mathrm{H}$ NMR : $\left(400 \mathrm{MHz}, \mathrm{CDCl}_{3}\right) \delta 7.94(\mathrm{dd}, J=7.9,1.2 \mathrm{~Hz}, 1 \mathrm{H}, \mathrm{ArH}), 7.69(\mathrm{dd}, J=7.8,1.7 \mathrm{~Hz}, 1 \mathrm{H}$, $\operatorname{ArH}), 7.38(\mathrm{~d}, J=8.7 \mathrm{~Hz}, 2 \mathrm{H}, \operatorname{ArH}), 7.36-7.32(\mathrm{~m}, 2 \mathrm{H}, \operatorname{ArH}), 7.31-7.26(\mathrm{~m}, 3 \mathrm{H}, \operatorname{ArH}), 7.25(\mathrm{~d}$, $J=1.7 \mathrm{~Hz}, 1 \mathrm{H}, \operatorname{ArH}), 7.09$ (dd, $J=7.8,1.7 \mathrm{~Hz}, 1 \mathrm{H}, \operatorname{ArH}), 6.89-6.84(\mathrm{~m}, 2 \mathrm{H}, \mathrm{ArH}), 4.12-4.05$ (m, $\left.1 \mathrm{H}, \mathrm{CH}_{2} \mathrm{CHCC}\right), 3.79\left(\mathrm{~s}, 3 \mathrm{H}, \mathrm{OCH}_{3}\right), 2.54-2.46\left(\mathrm{~m}, 2 \mathrm{H}, \mathrm{OCCH}_{2} \mathrm{CH}\right), 1.82\left(\mathrm{~s}, 3 \mathrm{H}, \mathrm{CH}_{2} \mathrm{C}\left(\mathrm{CH}_{3}\right)_{2}\right)$, $1.76\left(\mathrm{~s}, 3 \mathrm{H}, \mathrm{CH}_{2} \mathrm{C}\left(\mathrm{CH}_{3}\right)_{2}\right)$.

${ }^{13} \mathrm{C}$ NMR $\left(101 \mathrm{MHz}, \mathrm{CDCl}_{3}\right) \delta 166.0,158.5,141.1,136.7,134.9,132.2,131.6,131.0,128.6$, $128.3,127.9,127.8,123.8,114.2,93.8,92.5,84.2$, 83.6, 55.4, 49.2, 33.4, 27.2, 26.6.

IR $\left(v_{\max }, \mathrm{cm}^{-1}\right) 2977$ (w), 2932 (w), 2835 (w), 2359 (w), 1723 (s), 1610 (w), 1583 (w), 1512 (s), $1299(\mathrm{~s}), 1251(\mathrm{~s}), 1122(\mathrm{~s}), 1103(\mathrm{~m}), 758(\mathrm{~m}), 741(\mathrm{~s})$.

HRMS (ESI/QTOF) m/z: [M + Na] ${ }^{+}$Calcd for $\mathrm{C}_{27} \mathrm{H}_{25} \mathrm{INaO}_{3}{ }^{+}$547.0741; Found 547.0740. 


\section{3-(4-Methoxyphenyl)-5-(p-tolyl)pent-4-yn-1-yl 2-iodobenzoate (3k)}<smiles>COc1ccc(C#CC(CCOC(=O)c2ccccc2I)c2ccc(C)cc2)cc1</smiles>

Following the general procedure B, starting from 1-cyclopropyl-4-methoxybenzene (1a) (29.6 mg, $200 \mu \mathrm{mol}, 1.00$ equiv) and 1-(p-tolylethynyl)-1,2-benziodoxol-3(1H)-one (2b) (181 mg, $500 \mu \mathrm{mol}, 2.50$ equiv) The crude mixture was purified by column chromatography on Biotage (Büchi flashpure cartridge $25 \mathrm{~g}$, gradient of Pentane:EtOAc from 99:5 to 88:12) affording 3-(4methoxyphenyl)-5-(p-tolyl)pent-4-yn-1-yl 2-iodobenzoate (3k) (45.8 mg, 89.7 umol, 45\% yield) as pale yellow oil.

$\mathbf{R}_{\mathbf{f}} \mathbf{R f}=0.4\left(\mathrm{SiO}_{2}, 10: 1\right.$ Pentane/ethyl acetate $)$.

${ }^{1} \mathrm{H}$ NMR $\left(400 \mathrm{MHz}, \mathrm{CDCl}_{3}\right) \delta 7.99(\mathrm{dd}, J=7.9,1.2 \mathrm{~Hz}, 1 \mathrm{H}, \mathrm{ArH}), 7.77$ (dd, $J=7.8,1.7 \mathrm{~Hz}, 1 \mathrm{H}$, $\operatorname{ArH}), 7.41-7.35(\mathrm{~m}, 3 \mathrm{H}, \mathrm{ArH}), 7.35-7.31(\mathrm{~m}, 2 \mathrm{H}, \mathrm{ArH}), 7.15(\mathrm{td}, J=7.7,1.7 \mathrm{~Hz}, 1 \mathrm{H}, \operatorname{ArH}), 7.12$ - $7.08(\mathrm{~m}, 2 \mathrm{H}, \mathrm{ArH}), 6.93-6.86(\mathrm{~m}, 2 \mathrm{H}, \mathrm{ArH}), 4.57\left(\mathrm{dt}, \mathrm{J}=11.1,6.6 \mathrm{~Hz}, 1 \mathrm{H}, \mathrm{OCH}_{2} \mathrm{CH}_{2}\right), 4.48(\mathrm{dt}$, $\left.J=11.3,5.9 \mathrm{~Hz}, 1 \mathrm{H}, \mathrm{OCH}_{2} \mathrm{CH}_{2}\right), 4.10\left(\mathrm{dd}, J=8.1,6.7 \mathrm{~Hz}, 1 \mathrm{H}, \mathrm{CCCHCH}_{2}\right), 3.80\left(\mathrm{~s}, 3 \mathrm{H}, \mathrm{OCH}_{3}\right), 2.34$ (s, $3 \mathrm{H}, \mathrm{ArCH}_{3}$ ), 2.28 (dtd, J = 8.0, 6.1, $1.8 \mathrm{~Hz}, 2 \mathrm{H}, \mathrm{CH}_{2} \mathrm{CH}_{2} \mathrm{CH}$ ).

${ }^{13} \mathrm{C}$ NMR $\left(101 \mathrm{MHz}, \mathrm{CDCl}_{3}\right) \delta 166.6,158.8,141.4,138.1,135.4,133.3,132.7,131.7,131.2$, $129.1,128.6,128.0,120.5,114.2,94.1,89.7,84.1,63.8,55.4,37.4,34.7,21.6$.

IR $\left(v_{\text {max }} \mathrm{cm}^{-1}\right) 2956(w), 2923(w), 1728(m), 1610(w), 1584(w), 1512(s), 1462(m), 1288(m)$, $1251(\mathrm{~s}), 1133(\mathrm{~m}), 820(\mathrm{~m}), 743(\mathrm{~m})$.

HRMS (APPI/LTQ-Orbitrap) m/z: [M + H] ${ }^{+}$Calcd for $\mathrm{C}_{26} \mathrm{H}_{24} \mathrm{IO}_{3}{ }^{+}$511.0765; Found 511.0782. 


\section{3-(4-Methoxyphenyl)-5-(4-(trifluoromethyl)phenyl)pent-4-yn-1-yl 2-iodobenzoate (3I)}<smiles>COc1ccc(C(C#Cc2ccc(C(F)(F)F)cc2)CCOC(=O)c2ccccc2I)cc1</smiles>

Following the general procedure B, starting from 1-cyclopropyl-4-methoxybenzene (1a) (29.6 mg, $200 \mu \mathrm{mol}, 1.00$ equiv) and 1-[4-trifluoromethylphenylethynyl]-1,2-benziodoxol-3(1H)one (2c) (208 mg, $500 \mu \mathrm{mol}, 2.50$ equiv). The crude mixture was purified by column chromatography on Biotage (Büchi flashpure cartridge $25 \mathrm{~g}$, gradient of Pentane:EtOAc from 97:3 to 88:12) affording 3-(4-methoxyphenyl)-5-(4-(trifluoromethyl)phenyl)pent-4-yn-1-yl 2iodobenzoate (3I) $(71.4 \mathrm{mg}, 127 \mu \mathrm{mol}, 63 \%$ yield) as pale yellow oil.

$\mathbf{R}_{\mathbf{f}}=0.29\left(\mathrm{SiO}_{2}, 20: 1\right.$ Pentane/ethyl acetate $)$.

${ }^{1} \mathrm{H}$ NMR $\left(400 \mathrm{MHz}, \mathrm{CDCl}_{3}\right) \delta 8.00(\mathrm{dd}, J=8.0,1.2 \mathrm{~Hz}, 1 \mathrm{H}, \mathrm{ArH}), 7.76(\mathrm{dd}, J=7.8,1.8 \mathrm{~Hz}, 1 \mathrm{H}$, $\operatorname{ArH}), 7.57-7.49(\mathrm{~m}, 4 \mathrm{H}, \operatorname{ArH}), 7.40-7.33(\mathrm{~m}, 3 \mathrm{H}, \operatorname{ArH}), 7.16(\mathrm{dd}, J=7.7,1.8 \mathrm{~Hz}, 1 \mathrm{H}, \operatorname{ArH})$, $6.93-6.85(\mathrm{~m}, 2 \mathrm{H}, \mathrm{ArH}), 4.56\left(\mathrm{dt}, J=11.1,6.6 \mathrm{~Hz}, 1 \mathrm{H}, \mathrm{OCH}_{2} \mathrm{CH}_{2}\right), 4.47(\mathrm{dt}, J=11.4,5.9 \mathrm{~Hz}, 1 \mathrm{H}$, $\left.\mathrm{OCH}_{2} \mathrm{CH}_{2}\right), 4.12\left(\mathrm{t}, J=7.4 \mathrm{~Hz}, 1 \mathrm{H}, \mathrm{CCCHCH}_{2}\right), 3.81\left(\mathrm{~s}, 3 \mathrm{H}, \mathrm{OCH}_{3}\right), 2.40-2.25\left(\mathrm{~m}, 2 \mathrm{H}, \mathrm{CH}_{2} \mathrm{CH}_{2} \mathrm{CH}\right)$. ${ }^{13} \mathrm{C}$ NMR $\left(101 \mathrm{MHz}, \mathrm{CDCl}_{3}\right) \delta 166.6,158.9,141.5,135.3,132.8,132.6,132.1,131.2,130.0$, 129.7, 128.6, 128.0, 127.4, 125.3 (q, J = 3.8 Hz), 114.4, 94.2, 93.4, 82.7, 63.6, 55.5, 37.1, 34.7. ${ }^{19} \mathrm{~F}$ NMR $\left.\left(377 \mathrm{MHz}^{\mathrm{CDCl}}\right)_{3}\right) \delta-62.8$.

IR ( $\left(v_{\max }, \mathrm{cm}^{-1}\right) 2956(w), 2932$ (w), $2838(w), 2233(w), 1511(\mathrm{~m}), 1323(\mathrm{~s}), 1251(\mathrm{~s}), 1176(\mathrm{~m})$, $1167(\mathrm{~m}), 1127$ (s), $1105(\mathrm{~m}), 1067(\mathrm{~m})$.

HRMS (ESI/QTOF) m/z: [M+ H] ${ }^{+}$Calcd for $\mathrm{C}_{26} \mathrm{H}_{21} \mathrm{~F}_{3} \mathrm{IO}_{3}{ }^{+}$565.0482; Found 565.0477. 


\section{5-(4-Chlorophenyl)-3-(4-methoxyphenyl)pent-4-yn-1-yl 2-iodobenzoate (3m)}<smiles>COc1ccc(C(C#Cc2ccc(Cl)cc2)CCOC(=O)c2ccccc2I)cc1</smiles>

Following the general procedure B, starting from 1-cyclopropyl-4-methoxybenzene (1a) (29.6 $\mathrm{mg}, 200 \mu \mathrm{mol}, 1.00$ equiv) and 1-[4-chlorophenylethynyl]-1,2-benziodoxol-3(1H)-one (2d) (191 mg, $500 \mu \mathrm{mol}, 2.50$ equiv). The crude mixture was purified by column chromatography on Biotage (Büchi flashpure cartridge $25 \mathrm{~g}$, gradient of pentane: ethyl acetate from 95:5 to 85:15) affording 5-(4-chlorophenyl)-3-(4-methoxyphenyl)pent-4-yn-1-yl 2-iodobenzoate (3m) (67.2 $\mathrm{mg}, 127 \mu \mathrm{mol}, 63 \%$ yield) as pale yellow oil.

$\mathbf{R f}=0.2\left(\mathrm{SiO}_{2}, 10: 1\right.$ pentane:ethyl acetate $)$.

${ }^{1} \mathrm{H}$ NMR $\left(400 \mathrm{MHz}, \mathrm{CDCl}_{3}\right) \delta 8.00(\mathrm{dd}, J=7.9,1.2 \mathrm{~Hz}, 1 \mathrm{H}, \mathrm{ArH}), 7.76(\mathrm{dd}, J=7.8,1.7 \mathrm{~Hz}, 1 \mathrm{H}$, $\operatorname{ArH}), 7.42-7.33(\mathrm{~m}, 5 \mathrm{H}, \operatorname{ArH}), 7.27(\mathrm{~s}, 1 \mathrm{H}, \operatorname{ArH}), 7.25(\mathrm{~d}, J=1.7 \mathrm{~Hz}, 1 \mathrm{H}, \operatorname{ArH}), 7.15(\mathrm{td}, J=7.7$, $1.7 \mathrm{~Hz}, 1 \mathrm{H}, \mathrm{ArH}), 6.93-6.86(\mathrm{~m}, 2 \mathrm{H}, \mathrm{ArH}), 4.55\left(\mathrm{dt}, J=11.1,6.6 \mathrm{~Hz}, 1 \mathrm{H}, \mathrm{OCH}_{2} \mathrm{CH}_{2}\right), 4.46(\mathrm{dt}, J$ $\left.=11.4,5.9 \mathrm{~Hz}, 1 \mathrm{H}, \mathrm{OCH}_{2} \mathrm{CH}_{2}\right), 4.09\left(\mathrm{~m}, 1 \mathrm{H}, \mathrm{CCCHCH}_{2}\right), 3.80\left(\mathrm{~s}, 3 \mathrm{H}, \mathrm{OCH}_{3}\right), 2.36-2.21(\mathrm{~m}, 2 \mathrm{H}$, $\mathrm{CH}_{2} \mathrm{CH}_{2} \mathrm{CH}$ ).

${ }^{13} \mathrm{C}$ NMR $\left(101 \mathrm{MHz}, \mathrm{CDCl}_{3}\right) \delta 166.6,158.8,141.5,135.3,134.0,133.1,132.9,132.8,131.2$, $128.7,128.6,128.0,122.0,114.3,94.2$, 91.6, 82.9, 63.7, 55.5, 37.2, 34.7.

IR ( $\left.v_{\max }, \mathrm{cm}^{-1}\right) 2956(w), 2925$ (w), $2838(w), 2229(w), 1725(\mathrm{~m}), 1512(\mathrm{~m}), 1488(\mathrm{~m}), 1289(\mathrm{~s})$, $1250(\mathrm{~s}), 1133(\mathrm{~m}), 1094(\mathrm{~m}), 1014(\mathrm{~m}), 829(\mathrm{~m}), 742(\mathrm{~m})$.

HRMS (ESI/QTOF) m/z: [M + H] ${ }^{+}$Calcd for $\mathrm{C}_{25} \mathrm{H}_{21} \mathrm{ClIO}_{3}{ }^{+}$531.0218; Found 531.0223. 


\section{5-(4-Fluorophenyl)-3-(4-methoxyphenyl)pent-4-yn-1-yl 2-iodobenzoate (3n)}<smiles>COc1ccc(C(C#Cc2ccc(F)cc2)CCOC(=O)c2ccccc2I)cc1</smiles>

Following the general procedure B, starting from 1-cyclopropyl-4-methoxybenzene (1a) (29.6 mg, $200 \mu \mathrm{mol}, 1.00$ equiv) and 1-[4-fluorophenylethynyl]-1,2-benziodoxol-3(1H)-one (2e) (183 mg, $500 \mu \mathrm{mol}, 2.50$ equiv). The crude mixture was purified by column chromatography on Biotage (Büchi flashpure cartridge $25 \mathrm{~g}$, gradient of pentane: ethyl acetate from 95:5 to 85:15) affording 5-(4-fluorophenyl)-3-(4-methoxyphenyl)pent-4-yn-1-yl 2-iodobenzoate (3n) (41.4 mg, $80.5 \mu \mathrm{mol}, 40 \%$ yield) as pale yellow oil.

$\mathbf{R f}=0.29\left(\mathrm{SiO}_{2}, 20: 1\right.$ pentane:ethyl acetate $)$.

${ }^{1} \mathrm{H}$ NMR $\left(400 \mathrm{MHz}, \mathrm{CDCl}_{3}\right) \delta 8.00(\mathrm{dd}, J=8.0,1.2 \mathrm{~Hz}, 1 \mathrm{H}, \mathrm{ArH}), 7.76(\mathrm{dd}, J=7.8,1.7 \mathrm{~Hz}, 1 \mathrm{H}$, $\operatorname{ArH}), 7.42-7.34(\mathrm{~m}, 5 \mathrm{H}, \operatorname{ArH}), 7.15(\mathrm{td}, J=7.7,1.7 \mathrm{~Hz}, 1 \mathrm{H}, \operatorname{ArH}), 6.98(\mathrm{t}, J=8.7 \mathrm{~Hz}, 2 \mathrm{H}, \operatorname{ArH})$, $6.92-6.85(\mathrm{~m}, 2 \mathrm{H}, \mathrm{ArH}), 4.55\left(\mathrm{dt}, J=11.3,6.6 \mathrm{~Hz}, 1 \mathrm{H}, \mathrm{OCH}_{2} \mathrm{CH}_{2}\right), 4.46(\mathrm{dt}, J=11.3,5.9 \mathrm{~Hz}, 1 \mathrm{H}$, $\left.\mathrm{OCH}_{2} \mathrm{CH}_{2}\right), 4.09\left(\mathrm{t}, J=7.4 \mathrm{~Hz}, 1 \mathrm{H}, \mathrm{CCCHCH}_{2}\right), 3.80\left(\mathrm{~s}, 3 \mathrm{H}, \mathrm{OCH}_{3}\right), 2.34-2.23\left(\mathrm{~m}, 2 \mathrm{H}, \mathrm{CH}_{2} \mathrm{CH}_{2} \mathrm{CH}\right)$. ${ }^{13} \mathrm{C}$ NMR $\left(201 \mathrm{MHz}, \mathrm{CDCl}_{3}\right) \delta 166.6,162.4$ (d, $\left.J=248.8 \mathrm{~Hz}\right), 158.8,141.5,135.4,133.7$ (d, $J=$ 8.4 Hz), 133.1, 132.8, 131.2, 128.6, 128.0, 119.6, 115.6 (d, J = $22.2 \mathrm{~Hz}$ ), 114.3, 94.2, 90.2, 82.9, $63.8,55.5,37.3,34.6$.

${ }^{19}$ F NMR $\left(377 \mathrm{MHz}, \mathrm{CDCl}_{3}\right) \delta-111.6$.

IR $\left(v_{\text {max }}, \mathrm{cm}^{-1}\right) 2959(\mathrm{~m}), 2929$ (w), $2228(\mathrm{w}), 2150$ (w), $1721(\mathrm{~m}), 1600$ (m), 1505 (s), 1288 (s), 1265 (s), 1255 (s), 1249 (s), 1231 (s), 1094 (m), 1030 (m), 1015 (s), 837 (s), 740 (s). HRMS (APCI/QTOF) m/z: [M + H] ${ }^{+}$Calcd for $\mathrm{C}_{25} \mathrm{H}_{21} \mathrm{FIO}_{3}{ }^{+}$515.0514; Found 515.0515. 


\section{5-(3-Fluorophenyl)-3-(4-methoxyphenyl)pent-4-yn-1-yl 2-iodobenzoate (30)}<smiles>COc1ccc(C(C#Cc2cccc(F)c2)CCOC(=O)c2ccccc2I)cc1</smiles>

Following the general procedure B, starting from 1-cyclopropyl-4-methoxybenzene (1a) (29.6 $\mathrm{mg}, 200 \mu \mathrm{mol}, 1.00$ equiv) and 1-[3-fluorophenylethynyl]-1,2-benziodoxol-3(1H)-one (2f) (183 $\mathrm{mg}, 500 \mu \mathrm{mol}, 2.50$ equiv). The crude mixture was purified by column chromatography on Biotage (Büchi flashpure cartridge $25 \mathrm{~g}$, gradient of pentane: ethyl acetate from 95:5 to 85:15) affording 5-(3-fluorophenyl)-3-(4-methoxyphenyl)pent-4-yn-1-yl 2-iodobenzoate (30) (28.2 $\mathrm{mg}, 54.8 \mu \mathrm{mol}, 27 \%$ yield) as pale yellow oil.

$\mathbf{R f}=0.26\left(\mathrm{SiO}_{2}, 10: 1\right.$ pentane:ethyl acetate $)$

${ }^{1} \mathrm{H}$ NMR $\left(400 \mathrm{MHz}, \mathrm{CDCl}_{3}\right) \delta 8.00(\mathrm{dd}, J=7.9,1.2 \mathrm{~Hz}, 1 \mathrm{H}, \mathrm{ArH}), 7.77$ (dd, $J=7.8,1.7 \mathrm{~Hz}, 1 \mathrm{H}$, $\operatorname{ArH}), 7.41-7.33(\mathrm{~m}, 3 \mathrm{H}, \mathrm{ArH}), 7.26-7.19(\mathrm{~m}, 2 \mathrm{H}, \mathrm{ArH}), 7.18-7.10(\mathrm{~m}, 2 \mathrm{H}, \mathrm{ArH}), 7.03-6.96$ $(\mathrm{m}, 1 \mathrm{H}, \mathrm{ArH}), 6.93-6.87(\mathrm{~m}, 2 \mathrm{H}, \mathrm{ArH}), 4.59-4.51\left(\mathrm{~m}, 1 \mathrm{H}, \mathrm{OCH}_{2} \mathrm{CH}_{2}\right), 4.50-4.42(\mathrm{~m}, 1 \mathrm{H}$, $\left.\mathrm{OCH}_{2} \mathrm{CH}_{2}\right), 4.10\left(\mathrm{t}, J=7.4 \mathrm{~Hz}, 1 \mathrm{H}, \mathrm{CCCHCH}_{2}\right), 3.81\left(\mathrm{~s}, 3 \mathrm{H}, \mathrm{OCH}_{3}\right), 2.29(\mathrm{dt}, J=7.3,6.2 \mathrm{~Hz}, 2 \mathrm{H}$, $\mathrm{CH}_{2} \mathrm{CH}_{2} \mathrm{CH}$ ).

${ }^{13} \mathrm{C}$ NMR $\left(101 \mathrm{MHz}, \mathrm{CDCl}_{3}\right) \delta 166.5,162.3(\mathrm{~d}, J=246.2 \mathrm{~Hz}), 158.7,141.3,135.2,134.1,132.7$, 131.1, 129.8 (d, $J=8.7 \mathrm{~Hz}), 128.5,127.9,127.6$ (d, $J=3.2 \mathrm{~Hz}), 125.2$ (d, J = 9.5 Hz), 118.5 (d, J $=22.6 \mathrm{~Hz}$ ), $115.3(\mathrm{~d}, J=21.2 \mathrm{~Hz}), 114.2,94.0,91.6,82.7$ (d, $J=3.4 \mathrm{~Hz}), 63.5,55.3,37.1,34.5$. ${ }^{19} \mathrm{~F}$ NMR $\left(377 \mathrm{MHz}, \mathrm{CDCl}_{3}\right) \delta-113.2$.

IR $\left(v_{\max }, \mathrm{cm}^{-1}\right) 2931(\mathrm{w}), 2836(\mathrm{w}), 2229$ (w), $1726(\mathrm{~m}), 1581(\mathrm{~m}), 1510(\mathrm{~s}), 1288(\mathrm{~s}), 1247(\mathrm{~s})$, $1176(\mathrm{~m}), 1015(\mathrm{~m}), 785(\mathrm{~m}), 740(\mathrm{~s})$.

HRMS (APCl/QTOF) m/z: [M+ H] ${ }^{+}$Calcd for $\mathrm{C}_{25} \mathrm{H}_{21} \mathrm{FIO}_{3}{ }^{+}$515.0514; Found 515.0528. 


\section{5-(3-Fluorophenyl)-3-(4-methoxyphenyl)pent-4-yn-1-yl 2-iodo-4-methylbenzoate (3p)}<smiles>COc1ccc(C(C#Cc2cccc(F)c2)CCOC(=O)c2ccc(C)cc2I)cc1</smiles>

Following the general procedure B, starting from 1-cyclopropyl-4-methoxybenzene (1a) (29.6 mg, $200 \mu \mathrm{mol}, 1.00$ equiv) and 1-[3-fluorophenylethynyl]-5-methyl-1,2-benziodoxol-3(1H)one (2g) (190 mg, $500 \mu \mathrm{mol}, 2.50$ equiv). The crude mixture was purified by column chromatography on Biotage (Büchi flashpure cartridge $25 \mathrm{~g}$, gradient of pentane: ethyl acetate from 95:5 to 85:15) affording 5-(3-fluorophenyl)-3-(4-methoxyphenyl)pent-4-yn-1-yl 2-iodo-4-methylbenzoate (3p) (54.3 mg, $103 \mu \mathrm{mol}, 51 \%$ yield) as pale yellow oil.

$\mathbf{R f}=0.32\left(\mathrm{SiO}_{2}, 20: 1\right.$ pentane:ethyl acetate $)$

${ }^{1} \mathrm{H}$ NMR $\left(400 \mathrm{MHz}, \mathrm{CDCl}_{3}\right) \delta 7.84(\mathrm{~d}, J=8.1 \mathrm{~Hz}, 1 \mathrm{H}, \mathrm{ArH}), 7.57(\mathrm{dd}, J=2.2,0.8 \mathrm{~Hz}, 1 \mathrm{H}, \operatorname{ArH})$, 7.40 - $7.33(\mathrm{~m}, 2 \mathrm{H}, \operatorname{ArH}), 7.26-7.18(\mathrm{~m}, 2 \mathrm{H}, \operatorname{ArH}), 7.12(\mathrm{ddd}, J=9.5,2.6,1.4 \mathrm{~Hz}, 1 \mathrm{H}, \operatorname{ArH}), 6.96$ $-7.02(\mathrm{~m}, 2 \mathrm{H}, \mathrm{ArH}), 6.92-6.88(\mathrm{~m}, 2 \mathrm{H}, \mathrm{ArH}), 4.54\left(\mathrm{dt}, \mathrm{J}=11.1,6.7 \mathrm{~Hz}, 1 \mathrm{H}, \mathrm{OCH}_{2} \mathrm{CH}_{2}\right), 4.46(\mathrm{dt}$, $\left.J=11.3,6.0 \mathrm{~Hz}, 1 \mathrm{H}, \mathrm{OCH}_{2} \mathrm{CH}_{2}\right), 4.10\left(\mathrm{t}, J=7.4 \mathrm{~Hz}, 1 \mathrm{H}, \mathrm{CCCHCH}_{2}\right), 3.80\left(\mathrm{~s}, 3 \mathrm{H}, \mathrm{OCH}_{3}\right), 2.32(\mathrm{~s}$, $\left.3 \mathrm{H}, \mathrm{ArCH}_{3}\right), 2.32-2.26\left(\mathrm{~m}, 2 \mathrm{H}, \mathrm{CH}_{2} \mathrm{CH}_{2} \mathrm{CH}\right)$.

${ }^{13} \mathrm{C}$ NMR $\left(101 \mathrm{MHz}, \mathrm{CDCl}_{3}\right) \delta 166.8,162.5$ (d, J = 246.2 Hz), 158.8, 141.2, 138.3, 135.2, 133.8, 132.8, 131.9, 129.9 (d, J = 8.6 Hz), 128.6, 127.7 (d, J = 3.0 Hz), 125.4 (d, J = 9.4 Hz), 118.6 (d, J $=22.7 \mathrm{~Hz}$ ), $115.4(\mathrm{~d}, J=21.3 \mathrm{~Hz}), 114.3,91.7,90.0,82.8(\mathrm{~d}, J=3.3 \mathrm{~Hz}), 63.6,55.4,37.2,34.6$, 20.9 .

${ }^{19} \mathrm{~F}$ NMR $\left(377 \mathrm{MHz}, \mathrm{CDCl}_{3}\right) \delta-113.2$.

IR $\left(v_{\max }, \mathrm{cm}^{-1}\right) 2958(w), 2836(w), 2363(w), 2232(w), 1724(s), 1611(\mathrm{~m}), 1579(\mathrm{~m}), 1512(\mathrm{~s})$, $1294(\mathrm{~s}), 1249(\mathrm{~s}), 1203(\mathrm{~s}), 1173(\mathrm{~m}), 1108(\mathrm{~m}), 1036(\mathrm{~m}), 1015$ (m), $779(\mathrm{~m})$.

HRMS (APCl/QTOF) m/z: [M + H] ${ }^{+}$Calcd for $\mathrm{C}_{26} \mathrm{H}_{23} \mathrm{FIO}_{3}{ }^{+}$529.0670; Found 529.0679. 


\section{3-(4-Methoxyphenyl)-5-phenylpent-4-yn-1-yl 2-iodo-4,5-dimethoxybenzoate (3q)}

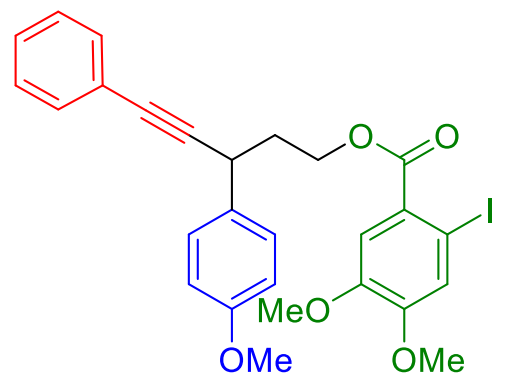

Following the general procedure B, starting from 1-cyclopropyl-4-methoxybenzene (1a) (29.6 mg, $200 \mu \mathrm{mol}, 1.00$ equiv) and 4,5-dimethoxy-1-[phenylethynyl]-1,2-benziodoxol-3(1H)-one (2h) (204 mg, $500 \mu \mathrm{mol}, 2.50$ equiv). The crude mixture was purified by column chromatography on Biotage (Büchi flashpure cartridge $25 \mathrm{~g}$, gradient of pentane: ethyl acetate from 85:15 to 70:30) affording 3-(4-methoxyphenyl)-5-phenylpent-4-yn-1-yl 2-iodo4,5-dimethoxybenzoate (3q) (33.7 mg, $60.6 \mu \mathrm{mol}, 30 \%$ yield) as colorless oil.

$\mathbf{R f}=0.14\left(\mathrm{SiO}_{2}, 10: 1\right.$ pentane:ethyl acetate $)$

${ }^{1} \mathrm{H}$ NMR $\left(400 \mathrm{MHz}, \mathrm{CDCl}_{3}\right) \delta 7.46-7.41(\mathrm{~m}, 3 \mathrm{H}, \mathrm{ArH}), 7.38(\mathrm{~d}, J=8.3 \mathrm{~Hz}, 3 \mathrm{H}, \mathrm{ArH}), 7.32-7.27$ $(\mathrm{m}, 3 \mathrm{H}, \mathrm{ArH}), 6.92-6.86(\mathrm{~m}, 2 \mathrm{H}, \mathrm{ArH}), 4.61-4.51\left(\mathrm{~m}, 1 \mathrm{H}, \mathrm{OCH}_{2} \mathrm{CH}_{2}\right), 4.51-4.43(\mathrm{~m}, 1 \mathrm{H}$, $\left.\mathrm{OCH}_{2} \mathrm{CH}_{2}\right), 4.11\left(\mathrm{dd}, J=8.2,6.6 \mathrm{~Hz}, 1 \mathrm{H}, \mathrm{CCCHCH}_{2}\right), 3.92\left(\mathrm{~s}, 3 \mathrm{H}, \mathrm{OCH}_{3}\right), 3.88\left(\mathrm{~s}, 3 \mathrm{H}, \mathrm{OCH}_{3}\right), 3.80$ (s, 3H, $\left.\mathrm{OCH}_{3}\right), 2.35-2.22\left(\mathrm{~m}, 2 \mathrm{H}, \mathrm{CH}_{2} \mathrm{CH}_{2} \mathrm{CH}\right)$.

${ }^{13} \mathrm{C}$ NMR $\left(201 \mathrm{MHz}, \mathrm{CDCl}_{3}\right) \delta 165.7,158.8,152.0,148.8,133.2,131.8,128.6,128.4,128.1$, 126.6, 123.8, 123.5, 114.2, 114.2, 90.6, 84.6, 84.0, 63.7, 56.4, 56.2, 55.5, 37.4, 34.7.

IR $\left(v_{\max }, \mathrm{cm}^{-1}\right) 2960(\mathrm{~m}), 2924(\mathrm{~m}), 2849(\mathrm{w}), 1720$ (m), 1510 (s), 1261 (s), 1246 (s), 1204 (s), $1174(\mathrm{~s}), 1111(\mathrm{~m}), 1024(\mathrm{~s}), 795(\mathrm{~m})$.

HRMS (ESI/QTOF) m/z: [M + Na] ${ }^{+}$Calcd for $\mathrm{C}_{27} \mathrm{H}_{25} \mathrm{INaO}_{5}{ }^{+}$579.0639; Found 579.0658. 


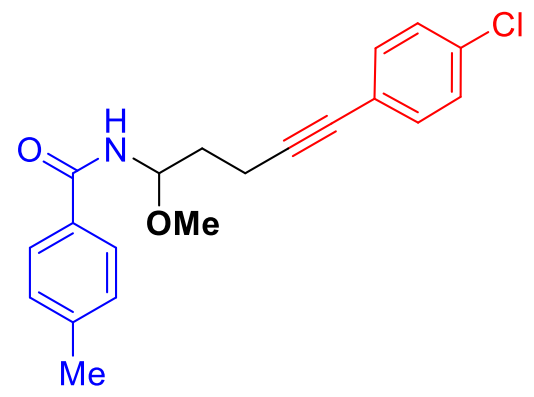

In a 12*75 mm Borosilicate glass tube, 2a $(95.6 \mathrm{mg}, 250 \mu \mathrm{mol}, 2.50$ equiv) and $\mathrm{N}$-cyclopropyl4-methylbenzamide (5a) (17.5 mg, $100 \mu \mathrm{mol}, 1.00$ equiv) were added. The tube was then closed with a rubber septum and sealed off with parafilm. Three cycles of evacuate-refill with nitrogen were performed to remove $\mathrm{O}_{2}$ and $\mathrm{DCM}(1.0 \mathrm{~mL}, 0.1 \mathrm{M})$ was added, followed by the addition of methanol $(6.41 \mathrm{mg}, 200 \mu \mathrm{mol}, 2.00$ equiv). The reaction mixture was stirred at room temperature irradiating with Kessil lamps $(440 \mathrm{~nm})$. The reaction was monitored by NMR with $\mathrm{CH}_{2} \mathrm{Br}_{2}$ as an internal standard. Upon completion by either full conversion of starting material or hypervalent iodine reagents, the mixture was concentrated in vacuo and purified by column chromatography to give product $6 a$ ( $18.1 \mathrm{mg}, 52.7 \mu \mathrm{mol}, 53 \%$ yield) as a white solid

${ }^{1} \mathrm{H}$ NMR $\left(400 \mathrm{MHz}, \mathrm{CDCl}_{3}\right) \delta 7.67(\mathrm{~d}, \mathrm{~J}=8.2 \mathrm{~Hz}, 2 \mathrm{H}, \mathrm{ArH}), 7.25(\mathrm{~d}, \mathrm{~J}=8.5 \mathrm{~Hz}, 2 \mathrm{H}, \operatorname{ArH}), 7.23$ (d, $J=8.7 \mathrm{~Hz}, 2 \mathrm{H}, \operatorname{ArH}), 7.15(\mathrm{~d}, \mathrm{~J}=8.0 \mathrm{~Hz}, 2 \mathrm{H}, \operatorname{ArH}) 6.63(\mathrm{~d}, J=9.6 \mathrm{~Hz}, 1 \mathrm{H}, \mathrm{NH}), 5.53(\mathrm{dt}, J=9.6$, $5.7 \mathrm{~Hz}, 1 \mathrm{H}, \mathrm{NHCH}), 3.43\left(\mathrm{~s}, 3 \mathrm{H}, \mathrm{OCH}_{3}\right), 2.65\left(\mathrm{dt}, J=17.1,7.0 \mathrm{~Hz}, 1 \mathrm{H}, \mathrm{CHCH}_{2} \mathrm{CH}_{2}\right), 2.54(\mathrm{dt}, J=$ 17.1, $\left.6.9 \mathrm{~Hz}, 1 \mathrm{H}, \mathrm{CHCH}_{2} \mathrm{CH}_{2}\right), 2.36\left(\mathrm{~s}, 3 \mathrm{H}, \mathrm{ArCH}_{3}\right), 2.09-1.94\left(\mathrm{~m}, 2 \mathrm{H}, \mathrm{CHCH}_{2} \mathrm{CH}_{2}\right)$.

${ }^{13} \mathrm{C}$ NMR $\left(101 \mathrm{MHz}, \mathrm{CDCl}_{3}\right) \delta 167.5,142.6,133.9,133.0,131.0,129.4,128.6,127.2,127.1$, $122.1,90.4,80.7,80.6,56.3,34.2,21.6,15.0$.

HRMS (ESI/QTOF) m/z: [M + Na] ${ }^{+}$Calcd for $\mathrm{C}_{20} \mathrm{H}_{20} \mathrm{CINNaO}_{2}{ }^{+} 364.1075$; Found 364.1075

Consistent with reported value. ${ }^{6}$ 


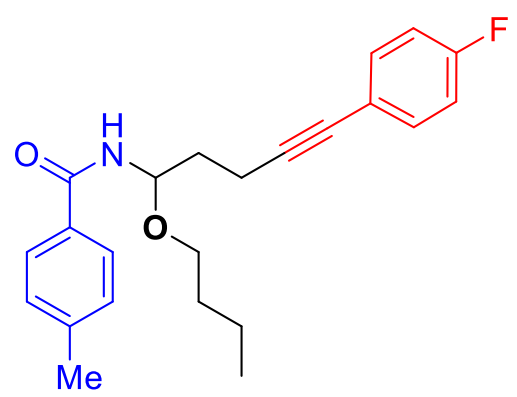

In a $12 * 75 \mathrm{~mm}$ Borosilicate glass tube, $2 \mathrm{a}(91.5 \mathrm{mg}, 250 \mu \mathrm{mol}, 2.50$ equiv) and $\mathrm{N}$-cyclopropyl4-methylbenzamide (5a) (17.5 mg, $100 \mu \mathrm{mol}, 1.00$ equiv) were added. The tube was then closed with a rubber septum and sealed off with parafilm. Three cycles of evacuate-refill with nitrogen were performed to remove $\mathrm{O}_{2}$ and $\mathrm{DCM}(1.0 \mathrm{~mL}, 0.1 \mathrm{M})$ was added, followed by the addition of methanol $(6.41 \mathrm{mg}, 200 \mu \mathrm{mol}, 2.00$ equiv). The reaction mixture was stirred at room temperature irradiating with Kessil lamps $(440 \mathrm{~nm})$. The reaction was monitored by NMR with $\mathrm{CH}_{2} \mathrm{Br}_{2}$ as an internal standard. Upon completion by either full conversion of starting material or hypervalent iodine reagents, the mixture was concentrated in vacuo and purified by column chromatography to give product $\mathbf{6 b}$ as a white solid $(18.7 \mathrm{mg}, 50.9 \mu \mathrm{mol}$, $51 \%$ yield)

${ }^{1} \mathrm{H}$ NMR $\left(400 \mathrm{MHz}, \mathrm{CDCl}_{3}\right) \delta(\mathrm{d}, \mathrm{J}=8.1 \mathrm{~Hz}, 2 \mathrm{H}, \mathrm{ArH}), 7.35-7.29(\mathrm{~m}, 2 \mathrm{H}, \mathrm{ArH}), 7.16(\mathrm{~d}, \mathrm{~J}=8.0$ $\mathrm{Hz}, 2 \mathrm{H}, \mathrm{ArH}), 6.99-6.91(\mathrm{~m}, 2 \mathrm{H}, \mathrm{ArH}), 6.60(\mathrm{~d}, J=9.5 \mathrm{~Hz}, 1 \mathrm{H}, \mathrm{NH}), 5.61$ (ddd, J = 9.5, 6.3, 5.5 $\mathrm{Hz}, 1 \mathrm{H}, \mathrm{NHCH}), 3.67\left(\mathrm{dt}, \mathrm{J}=9.5,6.6 \mathrm{~Hz}, 1 \mathrm{H}, \mathrm{OCH}_{2} \mathrm{CH}_{2}\right), 3.55\left(\mathrm{dt}, \mathrm{J}=9.6,6.6 \mathrm{~Hz}, 1 \mathrm{H}, \mathrm{OCH}_{2} \mathrm{CH}_{2}\right)$, $2.65\left(\mathrm{dt}, J=17.0,6.9 \mathrm{~Hz}, 1 \mathrm{H}, \mathrm{CHCH}_{2} \mathrm{CH}_{2}\right), 2.54\left(\mathrm{dt}, J=17.1,7.0 \mathrm{~Hz}, 1 \mathrm{H}, \mathrm{CHCH}_{2} \mathrm{CH}_{2}\right), 2.39(\mathrm{~s}, 3 \mathrm{H}$, $\left.\mathrm{ArCH}_{3}\right), 2.12-1.93\left(\mathrm{~m}, 2 \mathrm{H}, \mathrm{CHCH}_{2} \mathrm{CH}_{2}\right), 1.59-1.48\left(\mathrm{~m}, 2 \mathrm{H}, \mathrm{OCH}_{2} \mathrm{CH}_{2}\right), 1.46-1.32(\mathrm{~m}, 2 \mathrm{H}$, $\mathrm{OCH}_{2} \mathrm{CH}_{2} \mathrm{CH}_{2}$ ), $0.90\left(\mathrm{t}, J=7.4 \mathrm{~Hz}, 3 \mathrm{H}, \mathrm{CH}_{2} \mathrm{CH}_{3}\right.$ ).

${ }^{13} \mathrm{C}$ NMR (101 MHz, CDCl 3 ) $\delta 167.1,162.2$ (d, $\left.J=248.5 \mathrm{~Hz}\right), 142.3,133.4$ (d, J = 8.3 Hz), 131.1, 129.3, 127.0, 119.6 (d, J = 3.4 Hz), 115.4 (d, $J=21.9 \mathrm{~Hz}$ ), 88.9, 80.3, 79.2, 68.4, 34.4, 31.8, 21.5, $19.4,15.0,13.9$.

${ }^{19} \mathrm{~F}$ NMR $\left(376 \mathrm{MHz}, \mathrm{CDCl}_{3}\right) \delta-112.0$.

HRMS (ESI/QTOF) m/z: [M + Na] ${ }^{+}$Calcd for $\mathrm{C}_{23} \mathrm{H}_{26} \mathrm{FNNaO}_{2}{ }^{+} 390.1840$; Found 390.1846

Consistent with reported value. ${ }^{6}$ 


\section{3-(4-Methoxyphenyl)-5-phenylpent-4-yn-2-yl 2-iodobenzoate (8a)}<smiles>COc1ccc(C(C#Cc2ccccc2)C(C)OC(=O)c2ccccc2I)cc1</smiles>

Following the general procedure $B$, starting from 1-methoxy-4-[(E)-prop-1-enyl]benzene (7a) (29.6 mg, $200 \mu \mathrm{mol}, 1.00$ equiv) and phenyl ethynyl benziodoxolone (2a) (174 mg, $500 \mu \mathrm{mol}$, 2.50 equiv). The crude mixture was purified by column chromatography on Biotage (Büchi flashpure cartridge $25 \mathrm{~g}$, gradient of pentane: ethyl acetate from 95:5 to 88:12) affording 3(4-methoxyphenyl)-5-phenylpent-4-yn-2-yl 2-iodobenzoate (8a) as colorless oil (55.8 mg, 112 $\mu \mathrm{mol}, 56 \%$ yield for two diastereomers combined, $\mathrm{dr} 2: 1$, the ratio was determined by integration nof the ${ }^{1} \mathrm{H}$ NMR peaks of the benzylic protons $\mathrm{ArCH}$ ).

$\mathbf{R f}=0.35\left(\mathrm{SiO}_{2}, 20: 1\right.$ pentane:ethyl acetate $)$.

${ }^{1} \mathrm{H}$ NMR (400 MHz, $\mathrm{CDCl}_{3}$, signals for major diastereomer) $\delta 7.98(\mathrm{dt}, J=7.9,1.4 \mathrm{~Hz}, 1 \mathrm{H}, \mathrm{ArH})$, $7.78(\mathrm{dd}, J=7.8,1.7 \mathrm{~Hz}, 1 \mathrm{H}, \operatorname{ArH}), 7.44-7.41(\mathrm{~m}, 2 \mathrm{H}, \operatorname{ArH}), 7.41-7.38(\mathrm{~m}, 2 \mathrm{H}, \operatorname{ArH}), 7.36-7.37$ $(\mathrm{m}, 1 \mathrm{H}, \operatorname{ArH}), 7.31-7.27(\mathrm{~m}, 3 \mathrm{H}, \mathrm{ArH}), 7.13(\mathrm{td}, J=7.7,1.7 \mathrm{~Hz}, 1 \mathrm{H}, \operatorname{ArH}), 6.93-6.86(\mathrm{~m}, 2 \mathrm{H}$, $\operatorname{ArH}), 5.49\left(\mathrm{p}, J=6.3 \mathrm{~Hz}, 1 \mathrm{H}, \mathrm{OCH}\left(\mathrm{CH}_{3}\right) \mathrm{CH}_{2}\right), 4.18\left(\mathrm{~d}, J=5.9 \mathrm{~Hz}, 1 \mathrm{H}, \operatorname{ArCHCH}\left(\mathrm{CH}_{3}\right)\right), 3.81(\mathrm{~s}, 3 \mathrm{H}$, $\left.\mathrm{OCH}_{3}\right), 1.42\left(\mathrm{~d}, J=6.3 \mathrm{~Hz}, 3 \mathrm{H}, \mathrm{CH}\left(\mathrm{CH}_{3}\right)\right)$.

${ }^{13} \mathrm{C}$ NMR (101 MHz, CDCl 3 , signals for major diastereomer) $\delta 165.8,159.2,141.4,135.3,132.7$, $131.8,131.1,129.9,129.7,128.4,128.2$, 128.0, 123.4, 114.0, 94.3, 88.3, 84.6, 74.7, 55.4, 43.4, 17.7.

IR $\left(v_{\max }, \mathrm{cm}^{-1}\right) 2987(w), 2933(w), 2836(w), 1738(\mathrm{~m}), 1721(\mathrm{~s}), 1512(\mathrm{~m}), 1289(\mathrm{~s}), 1250(\mathrm{~s})$, $1179(\mathrm{~m}), 1129(\mathrm{~m}), 1101(\mathrm{~m}), 1065(\mathrm{~m}), 1057(\mathrm{~m}), 1032(\mathrm{~m}), 1012(\mathrm{~m}), 833(\mathrm{~m}), 758(\mathrm{~m}), 741$ (s).

HRMS (ESI/QTOF) m/z: [M + Na] ${ }^{+}$Calcd for $\mathrm{C}_{25} \mathrm{H}_{21} \mathrm{INaO}_{3}{ }^{+} 519.0428$; Found 519.0436. 


\section{2-(4-Methoxyphenyl)-4-phenylbut-3-yn-1-yl 2-iodobenzoate (8b)}<smiles>COc1ccc(C(C#Cc2ccccc2)COC(=O)c2ccccc2I)cc1</smiles>

Following the general procedure B, starting from 1-ethenyl-4-methoxybenzene (7b) (26.8 mg, $200 \mu \mathrm{mol}, 1.00$ equiv) and phenyl ethynyl benziodoxolone (2a) (174 mg, $500 \mu \mathrm{mol}, 2.50$ equiv). The crude mixture was purified by column chromatography on Biotage (Büchi flashpure cartridge $25 \mathrm{~g}$, gradient of pentane: ethyl acetate from 95:5 to 90:10) affording 2(4-methoxyphenyl)-4-phenylbut-3-yn-1-yl 2-iodobenzoate (8b) (42.6 mg, $88.3 \mu \mathrm{mol}, 44 \%$ yield) as colorless oil.

$\mathbf{R f}=0.33\left(\mathrm{SiO}_{2}, 20: 1\right.$ pentane:ethyl acetate $)$.

${ }^{1} \mathbf{H}$ NMR $\left(400 \mathrm{MHz}, \mathrm{CDCl}_{3}\right) \delta 7.99(\mathrm{dd}, J=7.9,1.2 \mathrm{~Hz}, 1 \mathrm{H}, \mathrm{ArH}), 7.81(\mathrm{dd}, J=7.8,1.7 \mathrm{~Hz}, 1 \mathrm{H}$, $\operatorname{ArH}), 7.49-7.42(\mathrm{~m}, 4 \mathrm{H}, \mathrm{ArH}), 7.37(\mathrm{td}, J=7.6,1.2 \mathrm{~Hz}, 1 \mathrm{H}, \operatorname{ArH}), 7.33-7.27(\mathrm{~m}, 3 \mathrm{H}, \mathrm{ArH}), 7.15$ $(\mathrm{td}, J=7.7,1.7 \mathrm{~Hz}, 1 \mathrm{H}, \mathrm{ArH}), 6.95-6.88(\mathrm{~m}, 2 \mathrm{H}, \mathrm{ArH}), 4.63-4.51\left(\mathrm{~m}, 2 \mathrm{H}, \mathrm{OCH}_{2} \mathrm{CH}\right), 4.34(\mathrm{t}, J$ $\left.=7.2 \mathrm{~Hz}, 1 \mathrm{H}, \mathrm{OCH}_{2} \mathrm{CHCC}\right) .3 .82\left(\mathrm{~s}, 3 \mathrm{H}, \mathrm{OCH}_{3}\right)$.

${ }^{13} \mathrm{C}$ NMR $\left(101 \mathrm{MHz}, \mathrm{CDCl}_{3}\right) \delta$ 166.2, 159.2, 141.6, 134.8, 132.9, 131.9, 131.3, 129.7, 129.3, $128.4,128.3,128.0,123.3,114.3,94.4,88.2,84.4,69.1,55.5,37.6$.

IR (IR ( $\left.v_{\max }, \mathrm{cm}^{-1}\right) 3058(w), 2954(w), 2836(w), 2061(w), 1728(s), 1610(\mathrm{~m}), 1583(\mathrm{~m}), 1511$ (s), $1463(\mathrm{~m}), 1307(\mathrm{~m}), 1287(\mathrm{~m}), 1246(\mathrm{~s}), 1178(\mathrm{~m}), 1132(\mathrm{~m}), 1098(\mathrm{~m}), 1033(\mathrm{~m}), 1013(\mathrm{~m})$, $830(\mathrm{~m}), 758(\mathrm{~m}), 740(\mathrm{~s})$.

HRMS (APPI/LTQ-Orbitrap) m/z: [M + H] ${ }^{+}$Calcd for $\mathrm{C}_{24} \mathrm{H}_{20} \mathrm{IO}_{3}{ }^{+}$483.0452; Found 483.0460. 


\section{2-(4-(Tert-butyl)phenyl)-4-phenylbut-3-yn-1-yl 2-iodobenzoate (8c)}<smiles>CC(C)(C)c1ccc(C(C#Cc2ccccc2)COC(=O)c2ccccc2I)cc1</smiles>

Following the general procedure B, starting from 1-tert-butyl-4-ethenylbenzene (7c) (32.1 mg, $200 \mu \mathrm{mol}, 1.00$ equiv) and phenyl ethynyl benziodoxolone (2a) (174 mg, $500 \mu \mathrm{mol}, 2.50$ equiv). The crude mixture was purified by column chromatography on Biotage (Büchi flashpure cartridge $25 \mathrm{~g}$, gradient of pentane: ethyl acetate from 99:1 to 90:10) affording 2(4-(tert-butyl)phenyl)-4-phenylbut-3-yn-1-yl 2-iodobenzoate (8c) (48.8 mg, 96.0 mol, 48\% yield) as colorless oil.

$\mathbf{R f}=0.55\left(\mathrm{SiO}_{2}, 10: 1\right.$ pentane:ethyl acetate $)$.

${ }^{1} \mathrm{H}$ NMR : $\left(400 \mathrm{MHz}, \mathrm{CDCl}_{3}\right) \delta 7.99(\mathrm{dd}, J=7.9,1.2 \mathrm{~Hz}, 1 \mathrm{H}, \mathrm{ArH}), 7.80(\mathrm{dd}, J=7.8,1.7 \mathrm{~Hz}, 1 \mathrm{H}$, $\operatorname{ArH}), 7.47(\mathrm{~d}, J=1.9 \mathrm{~Hz}, 1 \mathrm{H}, \operatorname{ArH}), 7.46-7.44(\mathrm{~m}, 2 \mathrm{H}, \operatorname{ArH}), 7.42(\mathrm{~s}, 1 \mathrm{H}, \operatorname{ArH}), 7.40-7.34(\mathrm{~m}$, $3 \mathrm{H}, \mathrm{ArH}), 7.32-7.29(\mathrm{~m}, 3 \mathrm{H}, \mathrm{ArH}), 7.18-7.13(\mathrm{~m}, 1 \mathrm{H}, \mathrm{ArH}), 4.59\left(\mathrm{~d}, J=7.2 \mathrm{~Hz}, 2 \mathrm{H}, \mathrm{OCH}_{2} \mathrm{CH}_{2}\right)$, $4.38(\mathrm{t}, J=7.2 \mathrm{~Hz}, 1 \mathrm{H}, \mathrm{CCCHCH} 2), 1.33\left(\mathrm{~s}, 9 \mathrm{H}, \mathrm{C}\left(\mathrm{CH}_{3}\right)_{3}\right)$.

${ }^{13} \mathrm{C}$ NMR $\left(101 \mathrm{MHz}, \mathrm{CDCl}_{3}\right) \delta 166.2,150.8,141.5,134.9,134.6,132.9,131.9,131.4,128.4$, $128.2,128.0,127.9,125.8,123.4,94.4,88.2,84.4,69.1,37.9,34.7,31.5$.

IR $\left(v_{\max }, \mathrm{cm}^{-1}\right) 2954(\mathrm{~m}), 2868(w), 2200(w), 1729$ (s), $1463(\mathrm{~m}), 1288$ (s), 1269 (s), 1249 (s), 1134 (s), 1100 (s), 1017 (m), 759 (s), 740 (s).

HRMS (APPI/LTQ-Orbitrap) m/z: [M + H] ${ }^{+}$Calcd for $\mathrm{C}_{27} \mathrm{H}_{26} \mathrm{IO}_{2}{ }^{+}$509.0972; Found 509.0986. 


\section{5-Methoxy-1,3-dimethyl-2-(1-(phenylethynyl)cyclopropyl)benzene (4a)}

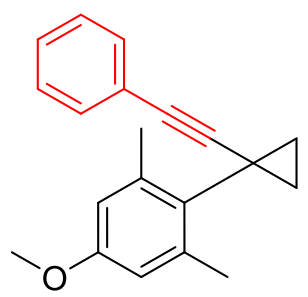

Following the general procedure B, starting from $\mathbf{1 g}(35.3 \mathrm{mg}, 200 \mu \mathrm{mol}, 1.00$ equiv) and $\mathbf{2 a}$ (104 mg, $300 \mu \mathrm{mol}, 1.50$ equiv). The crude mixture was purified by column chromatography on Biotage (Büchi flashpure cartridge 25 g, gradient of pentane: ethyl acetate from 99:1 to 95:5) affording (4a) (46.1 mg, $167 \mu \mathrm{mol}, 83 \%$ yield) of off-white amorphous solid.

$\mathbf{R f}=0.55\left(\mathrm{SiO}_{2}, 40: 1\right.$ pentane:ethyl acetate $)$

${ }^{1} \mathrm{H}$ NMR $\left(400 \mathrm{MHz}, \mathrm{CDCl}_{3}\right) \delta 7.37-7.31(\mathrm{~m}, 2 \mathrm{H}, \mathrm{ArH}), 7.23(\mathrm{~m}, 3 \mathrm{H}, \mathrm{ArH}), 6.59(\mathrm{~s}, 2 \mathrm{H}, \operatorname{ArH}), 3.78$ $\left(\mathrm{s}, 3 \mathrm{H}, \mathrm{OCH}_{3}\right), 2.53\left(\mathrm{~s}, 6 \mathrm{H}, 2 \times \mathrm{ArCH}_{3}\right), 1.55-1.49\left(\mathrm{~m}, 2 \mathrm{H}, \mathrm{CH}^{a} \mathrm{H}^{\mathrm{b}} \mathrm{CH}^{a} \mathrm{H}^{\mathrm{b}}\right), 1.17-1.09(\mathrm{~m}, 2 \mathrm{H}$, $\left.\mathrm{CH}^{\mathrm{a}} \mathrm{H}^{b} \mathrm{CH}^{\mathrm{a}} \mathrm{H}^{b}\right)$.

${ }^{13} \mathrm{C}$ NMR $\left(101 \mathrm{MHz}, \mathrm{CDCl}_{3}\right) \delta$ 158.3, 140.1, 131.8, 131.1, 128.2, 127.4, 124.2, 113.6, 94.5, 75.6, $55.2,20.9,19.8,13.0$.

IR $\left(v_{\max }, \mathrm{cm}^{-1}\right) 3005$ (w), $2955(w), 2922$ (w), 2836 (w), $2226(w), 1597(\mathrm{~m}), 1484(\mathrm{~m}), 1329(\mathrm{~m})$, $1313(\mathrm{~m}), 1158(\mathrm{~s}), 1058(\mathrm{~m}), 756(\mathrm{~s})$.

HRMS (ESI/QTOF) m/z: [M + H] ${ }^{+}$Calcd for $\mathrm{C}_{20} \mathrm{H}_{21} \mathrm{O}^{+}$277.1587; Found 277.1587.

\section{*Scale-up experiment}

In a schlenk tube $50 \mathrm{ml}, \mathbf{2 a}$ ( $5 \mathrm{mmol}, 2.5$ equiv) was added. The tube was then closed with a rubber septum and sealed off with parafilm. Three cycles of evacuate-refill with nitrogen were performed to remove $\mathrm{O}_{2}$ and $\mathrm{CHCl}_{3}(20 \mathrm{~mL}, 1 \mathrm{M})$ was added, followed by three cycles of Freeze Pump Thaw to completely remove $\mathrm{O}_{2}$. After that, $\mathbf{1 f}(353 \mathrm{mg}, 2.00 \mathrm{mmol}, 1.00$ equiv) was added under $\mathrm{N}_{2}$ atmosphere and the top of the schlenk tube was sealed again with parafilm . The reaction was monitored by $\mathrm{NMR}$ with $\mathrm{CH}_{2} \mathrm{Br}_{2}$ as internal standard. Upon complete conversion of the starting material, the mixture was concentrated in vacuo and purified by column chromatography on Biotage (Büchi flashpure cartridge $40 \mathrm{~g}$, gradient of pentane: ethyl acetate from 99:1 to 95:5) to give product 4a (511 mg, $1.85 \mathrm{mmol}, 92 \%$ yield). 


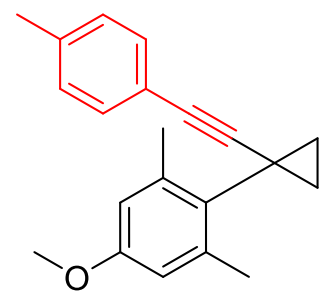

Following the general procedure B, starting from $1 \mathrm{~g}(35.3 \mathrm{mg}, 200 \mu \mathrm{mol}, 1.00$ equiv) and 1[tolylethynyl]-1,2-benziodoxol-3(1H)-one (2b) (109 mg, $300 \mu \mathrm{mol}, 1.50$ equiv). The crude mixture was purified by column chromatography on Biotage (Büchi flashpure cartridge $25 \mathrm{~g}$, gradient of pentane: ethyl acetate from 99:1 to 95:5) affording $4 \mathbf{b}$ (37.9 mg, $131 \mu \mathrm{mol}, 65 \%$ yield) as pale yellow oil.

$\mathbf{R f}=0.6\left(\mathrm{SiO}_{2}, 20: 1\right.$ pentane:ethyl acetate $)$.

${ }^{1} \mathrm{H}$ NMR : ${ }^{1} \mathrm{H}$ NMR $\left(400 \mathrm{MHz}, \mathrm{CDCl}_{3}\right) \delta 7.22(\mathrm{~d}, J=8.0 \mathrm{~Hz}, 2 \mathrm{H}, \mathrm{ArH}), 7.04(\mathrm{~d}, J=8.0 \mathrm{~Hz}, 2 \mathrm{H}, \operatorname{ArH})$, $6.58(\mathrm{~s}, 2 \mathrm{H}, \mathrm{ArH}), 3.77\left(\mathrm{~s}, 3 \mathrm{H}, \mathrm{OCH}_{3}\right), 2.53\left(\mathrm{~s}, 6 \mathrm{H}, \mathrm{ArCH}_{3}\right), 2.31(\mathrm{~s}, 3 \mathrm{H}), 1.51\left(\mathrm{~m}, 2 \mathrm{H}, \mathrm{CH}^{a} \mathrm{H}^{\mathrm{b}} \mathrm{CH}^{a} \mathrm{H}^{\mathrm{b}}\right)$, $1.13-1.05\left(\mathrm{~m}, 2 \mathrm{H}, \mathrm{CH}^{\mathrm{a}} \mathrm{H}^{b} \mathrm{CH}^{\mathrm{a}} \mathrm{H}^{b}\right)$.

${ }^{13} \mathrm{C}$ NMR ${ }^{13} \mathrm{C}$ NMR $\left(101 \mathrm{MHz}, \mathrm{CDCl}_{3}\right) \delta 158.3,140.1,137.4,131.7,131.3,128.9,121.1,113.6$, 93.7, 75.6, 55.2, 21.5, 20.9, 19.8, 13.1.

IR (film): IR ( $\left.V_{\max }, \mathrm{cm}^{-1}\right) 2921(\mathrm{~m}), 2838(\mathrm{w}), 2226$ (w), 1604 (s), 1507 (m), $1484(\mathrm{~m}), 1468(\mathrm{~m})$, $1462(\mathrm{~m}), 1327$ (s), 1311 (s), $1193(\mathrm{~m}), 1157$ (s), 1057 (m), $818(\mathrm{~s})$.

HRMS (APPI/LTQ-Orbitrap) m/z: [M] ${ }^{+}$Calcd for $\mathrm{C}_{21} \mathrm{H}_{22} \mathrm{O}^{+}$290.1665; Found 290.1671. 


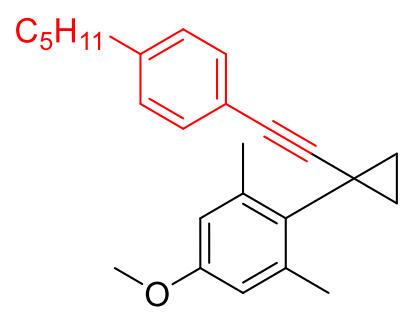

Following the general procedure B, starting from $1 \mathrm{~g}(35.3 \mathrm{mg}, 200 \mu \mathrm{mol}, 1.00$ equiv) and 1[4-n-pentylphenylethynyl]-1,2-benziodoxol-3(1H)-one (2i) (125 mg, $300 \mu \mathrm{mol}, 1.50$ equiv). The crude mixture was purified by column chromatography on Biotage (Büchi flashpure cartridge 25 g, gradient of pentane: ethyl acetate from 99:1 to 95:5) affording 4c (27.9 mg, $80.5 \mu \mathrm{mol}, 40 \%$ yield) as pale yellow oil.

$\mathbf{R f}=0.57\left(\mathrm{SiO}_{2}, 40: 1\right.$ pentane:ethyl acetate $)$.

${ }^{1} \mathrm{H}$ NMR : ${ }^{1} \mathrm{H}$ NMR $\left(400 \mathrm{MHz}, \mathrm{CDCl}_{3}\right) \delta 7.26-7.20(\mathrm{~m}, 2 \mathrm{H}, \mathrm{ArH}), 7.07-7.01(\mathrm{~m}, 2 \mathrm{H}, \mathrm{ArH}), 6.58$ $(\mathrm{s}, 2 \mathrm{H}, \mathrm{ArH}), 3.77\left(\mathrm{~s}, 3 \mathrm{H}, \mathrm{OCH}_{3}\right), 2.57-2.53\left(\mathrm{~m}, 2 \mathrm{H}, \mathrm{ArCH}_{2} \mathrm{CH}_{2}\right), 2.52\left(\mathrm{~s}, 6 \mathrm{H}, \mathrm{ArCH}_{3}\right) 1.61-1.54$ $\left(\mathrm{m}, 2 \mathrm{H}, \mathrm{ArCH}_{2} \mathrm{CH}_{2}\right), 1.53-1.47\left(\mathrm{~m}, 2 \mathrm{H}, \mathrm{CH}^{a} \mathrm{H}^{\mathrm{b}} \mathrm{CH}^{a} \mathrm{H}^{\mathrm{b}}\right), 1.35-1.23\left(\mathrm{~m}, 4 \mathrm{H}, \mathrm{ArC}_{2} \mathrm{H}_{4} \mathrm{C}_{2} \mathrm{H}_{4}\right), 1.13-$ $1.03\left(\mathrm{~m}, 2 \mathrm{H}, \mathrm{CH}^{\mathrm{a}} \mathrm{H}^{b} \mathrm{CH}^{\mathrm{a}} \mathrm{H}^{b}\right), 0.87\left(\mathrm{t}, J=7.0 \mathrm{~Hz}, 3 \mathrm{H}, \mathrm{ArC}_{4} \mathrm{H}_{8} \mathrm{CH}_{3}\right)$.

${ }^{13} \mathrm{C}$ NMR : ${ }^{13} \mathrm{C}$ NMR $\left(101 \mathrm{MHz}, \mathrm{CDCl}_{3}\right) \delta 158.3,142.5,140.1,131.7,131.3,128.3,121.3,113.5$, 93.7, 75.6, 55.2, 35.9, 31.5, 31.1, 22.6, 20.9, 19.8, 14.1, 13.1.

IR (film): IR ( $\left.v_{\max }, \mathrm{cm}^{-1}\right) 2957$ (s), 2924 (s), 2856 (m), 2224 (w), 1604 (s), 1508 (s), 1485 (s), 1462 (m), $1328(\mathrm{~s}), 1312(\mathrm{~s}), 1155$ (s), 1061 (s), 855 (m), 835 (s).

HRMS (APPI/LTQ-Orbitrap) m/z: [M] ${ }^{+}$Calcd for $\mathrm{C}_{25} \mathrm{H}_{30} \mathrm{O}^{+} 346.2291$; Found 346.2304. 
(4d)<smiles>COc1cc(C)c(C#CC2(C#Cc3ccc(C(F)(F)F)cc3)CC2)c(C)c1</smiles>

Following the general procedure B, starting from $1 \mathrm{~g}(35.3 \mathrm{mg}, 200 \mu \mathrm{mol}, 1.00$ equiv) and 1[4-trifluoromethylphenylethynyl]-1,2-benziodoxol-3(1H)-one 2c (124 mg, $300 \mu \mathrm{mol}, 1.50$ equiv). The crude mixture was purified by column chromatography on Biotage (Büchi flashpure cartridge $25 \mathrm{~g}$, gradient of pentane: ethyl acetate from 99:1 to 95:5) affording $\mathbf{4 d}$ (55.8 mg, $162 \mu \mathrm{mol}, 81 \%$ yield) as pale yellow oil.

$\mathbf{R f}=0.58\left(\mathrm{SiO}_{2}, 40: 1\right.$ pentane:ethyl acetate $)$.

${ }^{1} \mathrm{H}$ NMR $\left(400 \mathrm{MHz}, \mathrm{CDCl}_{3}\right) \delta 7.59-7.35(\mathrm{~m}, 4 \mathrm{H}, \mathrm{ArH}), 6.60(\mathrm{~s}, 2 \mathrm{H}, \mathrm{ArH}), 3.78\left(\mathrm{~s}, 3 \mathrm{H}, \mathrm{OCH}_{3}\right), 2.53$ (s, 6H, ArCH 3$), 1.61-1.53\left(\mathrm{~m}, 2 \mathrm{H}, \mathrm{CH}^{a} \mathrm{H}^{\mathrm{b}} \mathrm{CH}^{a} \mathrm{H}^{\mathrm{b}}\right), 1.20-1.09\left(\mathrm{~m}, 2 \mathrm{H}, \mathrm{CH}^{\mathrm{a}} \mathrm{H}^{b} \mathrm{CH}^{\mathrm{a}} \mathrm{H}^{b}\right)$.

${ }^{13} \mathrm{C}$ NMR $\left(101 \mathrm{MHz}, \mathrm{CDCl}_{3}\right) \delta 158.5,140.1,132.0,130.6,129.3,128.1,127.4,125.1$ (q, $J=3.8$ $\mathrm{Hz}), 113.7,97.4,74.5,55.2,20.9,20.0,13.0$.

${ }^{19} \mathrm{~F}$ NMR (377 $\left.\mathrm{MHz}, \mathrm{CDCl}_{3}\right) \delta-62.7$.

IR (film): IR ( $\left.v_{\max }, \mathrm{cm}^{-1}\right) 2956$ (w), 2925 (w), 2838 (w), 2226 (w), 2118 (w), 1604 (m), 1487 (m), 1322 (s), 1159 (s), 1126 (s), 1066 (s), $842(\mathrm{~m})$.

HRMS (APPI/LTQ-Orbitrap) m/z: [M] ${ }^{+}$Calcd for $\mathrm{C}_{21} \mathrm{H}_{19} \mathrm{~F}_{3} \mathrm{O}^{+}$344.1383; Found 344.1386. 
<smiles>COc1cc(C)c(C2(C#Cc3ccc(F)cc3)CC2)c(C)c1</smiles>

Following the general procedure B, starting from $1 \mathrm{~g}(35.3 \mathrm{mg}, 200 \mu \mathrm{mol}, 1.00$ equiv) and 1[4-Fluorophenylethynyl]-1,2-benziodoxol-3(1H)-one (2e) (110 mg, $300 \mu \mathrm{mol}, 1.50$ equiv). The crude mixture was purified by column chromatography on Biotage (Büchi flashpure cartridge $25 \mathrm{~g}$, gradient of pentane: ethyl acetate from 99:1 to 95:5) affording 4 e (41.3 mg, $140 \mu \mathrm{mol}$, $70 \%$ yield) as pale yellow oil.

$\mathbf{R f}=0.53\left(\mathrm{SiO}_{2}, 40: 1\right.$ pentane:ethyl acetate $)$.

${ }^{1} \mathrm{H}$ NMR : ${ }^{1} \mathrm{H}$ NMR $\left(400 \mathrm{MHz}, \mathrm{CDCl}_{3}\right) \delta 7.34-7.27(\mathrm{~m}, 2 \mathrm{H}, \mathrm{ArH}), 6.96-6.88(\mathrm{~m}, 2 \mathrm{H}, \mathrm{ArH}), 6.58$ $(\mathrm{s}, 2 \mathrm{H}, \mathrm{ArH}), 3.77\left(\mathrm{~s}, 3 \mathrm{H}, \mathrm{OCH}_{3}\right), 2.52\left(\mathrm{~s}, 6 \mathrm{H}, \mathrm{ArCH}_{3}\right), 1.53-1.48\left(\mathrm{~m}, 2 \mathrm{H},-\mathrm{CH}^{a} \mathrm{H}^{b} \mathrm{CH}^{a} \mathrm{H}^{\mathrm{b}}-\right), 1.13-$ $1.06\left(\mathrm{~m}, 2 \mathrm{H},-\mathrm{CH}^{\mathrm{a}} \mathrm{H}^{b} \mathrm{CH}^{\mathrm{a}} \mathrm{H}^{b}-\right)$.

${ }^{13} \mathrm{C}$ NMR : ${ }^{13} \mathrm{C}$ NMR $\left(101 \mathrm{MHz}, \mathrm{CDCl}_{3}\right) \delta 162.1$ (d, $\left.J=249.5 \mathrm{~Hz}\right), 158.4,140.1,133.6,133.6$, 131.0, 120.22 (d, J = 3.6 Hz), 115.5, 115.3, 113.6, 94.1, 74.5, 55.2, 20.9, 19.8, 13.0.

${ }^{19} \mathrm{~F}$ NMR $\left(377 \mathrm{MHz}, \mathrm{CDCl}_{3}\right) \delta-112.5$.

IR $\left(v_{\max }, \mathrm{cm}^{-1}\right) 3002(w), 2955(w), 2837(w), 2228(w), 1892(w), 1603(s), 1505(s), 1484(m)$, $1468(\mathrm{~m}), 1329(\mathrm{~m}), 1313(\mathrm{~s}), 1223(\mathrm{~s}), 1192(\mathrm{~m}), 1158(\mathrm{~s}), 1059(\mathrm{~m}), 836(\mathrm{~s})$.

HRMS (APPI/LTQ-Orbitrap) m/z: [M] ${ }^{+}$Calcd for $\mathrm{C}_{20} \mathrm{H}_{19} \mathrm{FO}^{+}$294.1414; Found 294.1429. 
2-(1-((4-Chlorophenyl)ethynyl)cyclopropyl)-5-methoxy-1,3-dimethylbenzene (4f)<smiles>COc1cc(C)c(C2(C#Cc3ccc(Cl)cc3)CC2)c(C)c1</smiles>

Following the general procedure B, starting from $1 \mathrm{~g}$ (35.3 mg, $200 \mu \mathrm{mol}, 1.00$ equiv) and 1-1[4-chlorophenylethynyl]-1,2-benziodoxol-3(1H)-one (2d) (115 mg, $300 \mu \mathrm{mol}, 1.50$ equiv). The crude mixture was purified by column chromatography on Biotage (Büchi flashpure cartridge $25 \mathrm{~g}$, gradient of pentane: ethyl acetate from 99:1 to 95:5) affording $\mathbf{4 f}$ (49.2 mg, $158 \mu \mathrm{mol}$, $79 \%$ yield) as pale yellow oil.

$\mathbf{R f}=0.52\left(\mathrm{SiO}_{2}, 40: 1\right.$ pentane:ethyl acetate $)$.

${ }^{1} \mathrm{H}$ NMR $\left(400 \mathrm{MHz}, \mathrm{CDCl}_{3}\right) \delta 7.26-7.16(\mathrm{~m}, 4 \mathrm{H}, \mathrm{ArH}), 6.58(\mathrm{~s}, 2 \mathrm{H}, \mathrm{ArH}), 3.77\left(\mathrm{~s}, 3 \mathrm{H}, \mathrm{OCH}_{3}\right), 2.52$ $\left(\mathrm{s}, 6 \mathrm{H}, \mathrm{ArCH}_{3}\right), 1.54-1.48\left(\mathrm{~m}, 2 \mathrm{H},-\mathrm{CH}^{a} \mathrm{H}^{b} \mathrm{CH}^{a} \mathrm{H}^{\mathrm{b}}-\right), 1.14-1.07\left(\mathrm{~m}, 2 \mathrm{H},-\mathrm{CH}^{\mathrm{a}} H^{b} \mathrm{CH}^{\mathrm{a}} \mathrm{H}^{b}-\right)$.

${ }^{13} \mathrm{C}$ NMR $\left(101 \mathrm{MHz}, \mathrm{CDCl}_{3}\right) \delta$ 158.4, 140.1, 133.3, 133.1, 130.8, 128.5, 122.7, 113.6, 95.6, 74.5, $55.2,20.9,19.9,13.0$.

IR $\left(v_{\text {max }}, \mathrm{cm}^{-1}\right) 3089(\mathrm{w}), 3003(\mathrm{~m}), 2954(\mathrm{~m}), 2837(\mathrm{w}), 2226(\mathrm{~m}), 1603(\mathrm{~s}), 1488(\mathrm{~s}), 1314(\mathrm{~s})$, $1158(\mathrm{~s}), 828(\mathrm{~s})$.

HRMS (APPI/LTQ-Orbitrap) m/z: [M] ${ }^{+}$Calcd for $\mathrm{C}_{20} \mathrm{H}_{19} \mathrm{ClO}^{+} 310.1119$; Found 310.1133. 
<smiles>COc1cc(C)c(C2(C#Cc3ccc(Br)cc3)CC2)c(C)c1</smiles>

Following the general procedure B, starting from $1 \mathrm{~g}(35.3 \mathrm{mg}, 200 \mu \mathrm{mol}, 1.00$ equiv) and 1[4-bromophenylethynyl]-1,2-benziodoxol-3(1H)-one $2 \mathrm{j}$ (128 mg, $300 \mu \mathrm{mol}, 1.50$ equiv). The crude mixture was purified by column chromatography on Biotage (Büchi flashpure cartridge $25 \mathrm{~g}$, gradient of pentane: ethyl acetate from 99:1 to 95:5) affording $\mathbf{4 g}$ (54.8 mg, $154 \mu \mathrm{mol}$, $77 \%$ yield) as pale yellow oil.

$\mathbf{R f}=0.57\left(\mathrm{SiO}_{2}, 20: 1\right.$ pentane:ethyl acetate $)$.

${ }^{1} \mathrm{H}$ NMR $\left(400 \mathrm{MHz}, \mathrm{CDCl}_{3}\right) \delta 7.41-7.33(\mathrm{~m}, 2 \mathrm{H}, \mathrm{ArH}), 7.22-7.15(\mathrm{~m}, 2 \mathrm{H}, \mathrm{ArH}), 6.59(\mathrm{~s}, 2 \mathrm{H}$, $\operatorname{ArH}), 3.77\left(\mathrm{~s}, 3 \mathrm{H}, \mathrm{OCH}_{3}\right), 2.52\left(\mathrm{~s}, 6 \mathrm{H}, \mathrm{ArCH}_{3}\right), 1.55-1.48\left(\mathrm{~m}, 2 \mathrm{H},-\mathrm{CH}^{a} \mathrm{H}^{\mathrm{b}} \mathrm{CH}^{a} \mathrm{H}^{\mathrm{b}}-\right), 1.16-1.08$ (m, $\left.2 \mathrm{H}, \mathrm{CH}^{\mathrm{a}} \mathrm{H}^{b} \mathrm{CH}^{\mathrm{a}} \mathrm{H}^{b}\right)$.

${ }^{13} \mathrm{C}$ NMR $\left(101 \mathrm{MHz} \mathrm{CDCl}_{3}\right) \delta 158.4,140.1,133.3,131.4,130.8,123.2,121.5,113.6,95.8$, 74.6, 55.2, 20.9, 19.9, 13.0 .

IR $\left(v_{\max }, \mathrm{cm}^{-1}\right) 3001(w), 2954(\mathrm{~m}), 2837(w), 2225$ (w), 1602 (s), 1484 (s), 1326 (s), 1312 (s), 1157 (s), 1066 (s), 1058 (s), 823 (s).

HRMS (APPI/LTQ-Orbitrap) m/z: [M + H] $]^{+}$Calcd for $\mathrm{C}_{20} \mathrm{H}_{20} \mathrm{BrO}^{+}$355.0692; Found 355.0707. 


\section{2-(1-((3-Fluorophenyl)ethynyl)cyclopropyl)-5-methoxy-1,3-dimethylbenzene (4h)}<smiles>COc1cc(C)c(C#CC2(C#Cc3cccc(F)c3)CC2)c(C)c1</smiles>

Following the general procedure B, starting from $1 \mathrm{~g}(35.3 \mathrm{mg}, 200 \mu \mathrm{mol}, 1.00$ equiv) and 1[3-fluorophenylethynyl]-1,2-benziodoxol-3(1H)-one $2 \mathrm{f}$ (110 mg, $300 \mu \mathrm{mol}, 1.50$ equiv). The crude mixture was purified by column chromatography on Biotage (Büchi flashpure cartridge $25 \mathrm{~g}$, gradient of pentane: ethyl acetate from 99:1 to 95:5) affording $4 \mathbf{h}$ (36.2 mg, $123 \mu \mathrm{mol}$, $61 \%$ yield) as pale yellow oil.

$\mathbf{R f}=0.3\left(\mathrm{SiO}_{2}, 40: 1\right.$ pentane:ethyl acetate $)$.

${ }^{1} \mathrm{H}$ NMR $\left(400 \mathrm{MHz}, \mathrm{CDCl}_{3}\right) \delta 7.18(\mathrm{td}, J=8.0,5.9 \mathrm{~Hz}, 1 \mathrm{H}, \mathrm{ArH}), 7.10(\mathrm{dt}, J=7.7,1.3 \mathrm{~Hz}, 1 \mathrm{H}, \mathrm{ArH})$, 7.02 (ddd, $J=9.8,2.7,1.5 \mathrm{~Hz}, 1 \mathrm{H}, \mathrm{ArH}), 6.96-6.89$ (m, 1H, ArH), 6.59 (s, 2H, ArH), 3.77 (s, 3H, $\left.\mathrm{OCH}_{3}\right), 2.52\left(\mathrm{~s}, 6 \mathrm{H}, \mathrm{ArCH}_{3}\right), 1.55-1.49\left(\mathrm{~m}, 2 \mathrm{H}, \mathrm{CH}^{a} \mathrm{H}^{b} \mathrm{CH}^{a} \mathrm{H}^{\mathrm{b}}\right), 1.15-1.09\left(\mathrm{~m}, 2 \mathrm{H}, \mathrm{CH}^{\mathrm{a}} \mathrm{H}^{b} \mathrm{CH}^{\mathrm{a}} H^{b}\right)$. ${ }^{13} \mathrm{C}$ NMR $\left(101 \mathrm{MHz}, \mathrm{CDCl}_{3}\right) \delta 162.4(\mathrm{~d}, J=245.8 \mathrm{~Hz}), 158.4,140.1,130.8,129.7$ (d, $\left.J=8.7 \mathrm{~Hz}\right)$, 127.7 (d, J = 2.9 Hz), 126.1 (d, J = 9.6 Hz), 118.6 (d, J = 22.5 Hz), 114.8 (d, J = 21.1 Hz), 113.6, 95.7, 74.5 (d, $J=3.4 \mathrm{~Hz}), 55.2,20.9,19.9,13.0$.

${ }^{19} \mathrm{~F}$ NMR $\left(377 \mathrm{MHz}, \mathrm{CDCl}_{3}\right) \delta-113.6$.

IR $\left(v_{\max }, \mathrm{cm}^{-1}\right) 2957(\mathrm{~m}), 2837(\mathrm{w}), 2220(\mathrm{~m}), 1606(\mathrm{~s}), 1579(\mathrm{~s}), 1487(\mathrm{~s}), 1467(\mathrm{~m}), 1315(\mathrm{~s})$, 1159 (s), 1059 (m), 920 (s), 783 (s).

HRMS (APPI/LTQ-Orbitrap) m/z: [M + H] ${ }^{+}$Calcd for $\mathrm{C}_{20} \mathrm{H}_{20} \mathrm{FO}^{+}$295.1493; Found 295.1489. 


\section{2-(1-((2-Bromophenyl)ethynyl)cyclopropyl)-5-methoxy-1,3-dimethylbenzene (4i)}<smiles>COc1cc(C)c(C2(C#Cc3ccccc3Br)CC2)c(C)c1</smiles>

Following the general procedure B, starting from $\mathbf{1 g}(35.3 \mathrm{mg}, 200 \mu \mathrm{mol}, 1.00$ equiv) and 1[2-bromophenylethynyl]-1,2-benziodoxol-3(1H)-one (2k) (128 mg, $300 \mu \mathrm{mol}, 1.50$ equiv). The crude mixture was purified by column chromatography on Biotage (Büchi flashpure cartridge 25 g, gradient of pentane: ethyl acetate from 99:1 to 95:5) affording $4 \mathbf{i}$ (38.5 mg, $108 \mu \mathrm{mol}$, $54 \%$ yield) as pale yellow oil.

$\mathbf{R f}=0.5\left(\mathrm{SiO}_{2}, 40: 1\right.$ pentane:ethyl acetate $)$.

${ }^{1} \mathrm{H}$ NMR $\left(400 \mathrm{MHz}, \mathrm{CDCl}_{3}\right) \delta 7.51(\mathrm{dd}, J=8.0,1.3 \mathrm{~Hz}, 1 \mathrm{H}, \mathrm{ArH}), 7.35$ (dd, $J=7.7,1.7 \mathrm{~Hz}, 1 \mathrm{H}$, $\operatorname{ArH}), 7.17(\mathrm{td}, J=7.6,1.3 \mathrm{~Hz}, 1 \mathrm{H}, \operatorname{ArH}), 7.07(\mathrm{ddd}, J=8.1,7.4,1.7 \mathrm{~Hz}, 1 \mathrm{H}, \operatorname{ArH}), 6.62-6.56(\mathrm{~m}$, $2 \mathrm{H}, \mathrm{ArH}), 3.77\left(\mathrm{~s}, 3 \mathrm{H}, \mathrm{OCH}_{3}\right), 2.54\left(\mathrm{~s}, 6 \mathrm{H}, \mathrm{ArCH}_{3}\right), 1.66-1.56\left(\mathrm{~m}, 2 \mathrm{H}, \mathrm{CH}^{a} \mathrm{H}^{\mathrm{b}} \mathrm{CH}^{a} \mathrm{H}^{\mathrm{b}}\right), 1.20-1.09$ (m, $\left.2 \mathrm{H}, \mathrm{CH}^{\mathrm{a}} \mathrm{H}^{b} \mathrm{CH}^{\mathrm{a}} \mathrm{H}^{b}\right)$.

${ }^{13} \mathrm{C}$ NMR $\left(101 \mathrm{MHz}, \mathrm{CDCl}_{3}\right) \delta$ 158.4, 140.2, 133.3, 132.3, 130.7, 128.6, 126.9, 126.1, 126.1, $113.6,99.7,74.4,55.2,20.9,20.0,13.2$.

IR $\left(v_{\max }, \mathrm{cm}^{-1}\right) 3001$ (w), 2955 (w), 2836 (w), 2229 (w), 1750 (w), 1603 (s), 1485 (m), 1467 (s), $1330(\mathrm{~m}), 1314$ (s), 1158 (s), $1058(\mathrm{~m}), 1028$ (m), 754 (s).

HRMS (APPI/LTQ-Orbitrap) m/z: [M] Calcd for $\mathrm{C}_{20} \mathrm{H}_{19} \mathrm{BrO}^{+}$354.0614; Found 354.0630. 
NMR spectra

${ }^{1} \mathrm{H}-\mathrm{NMR}\left(400 \mathrm{MHz}, \mathrm{CDCl}_{3}\right)$ (1c)
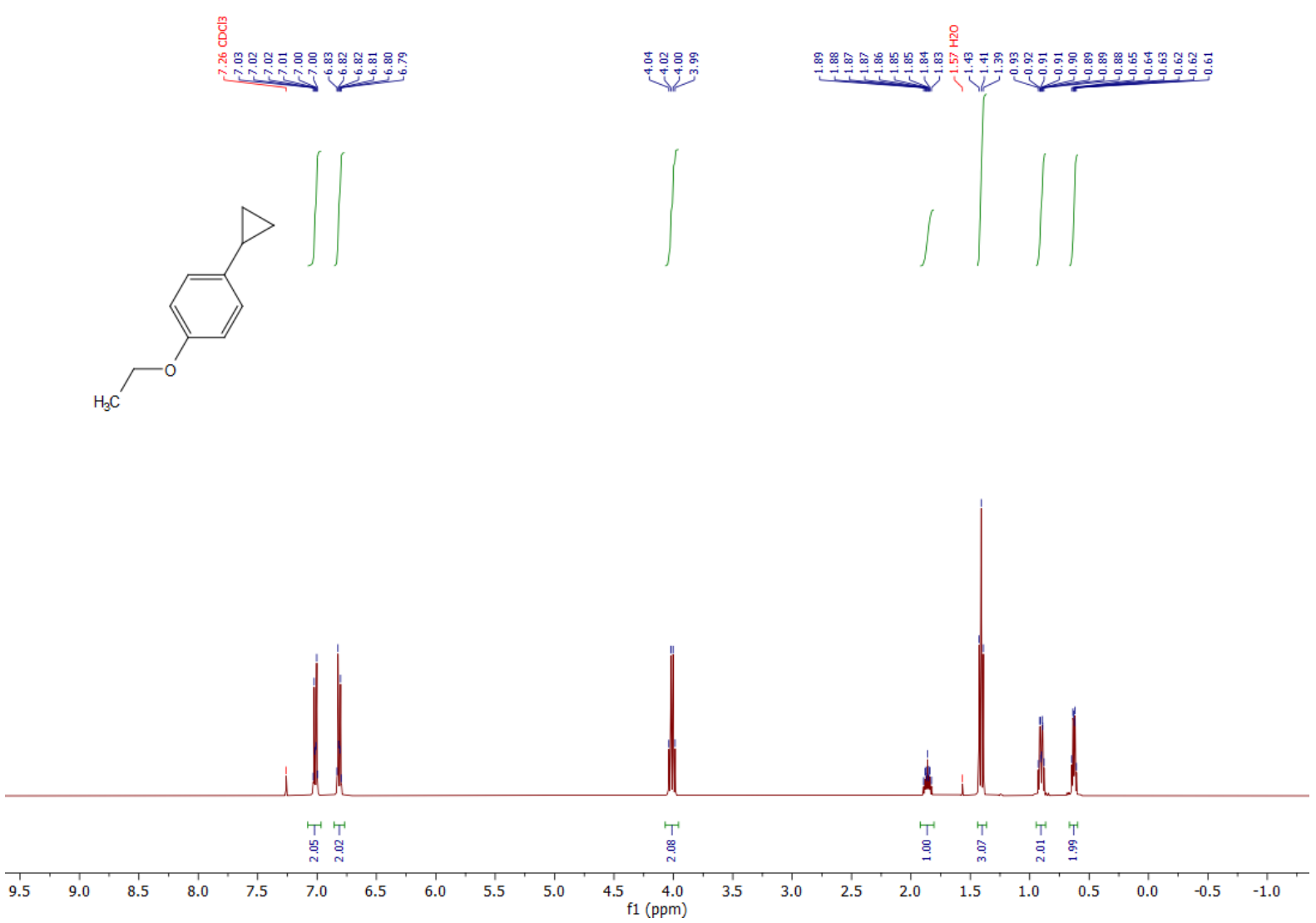

${ }^{13} \mathrm{C}$ NMR (101 MHz, $\mathrm{CDCl}_{3}$ ) (1c)
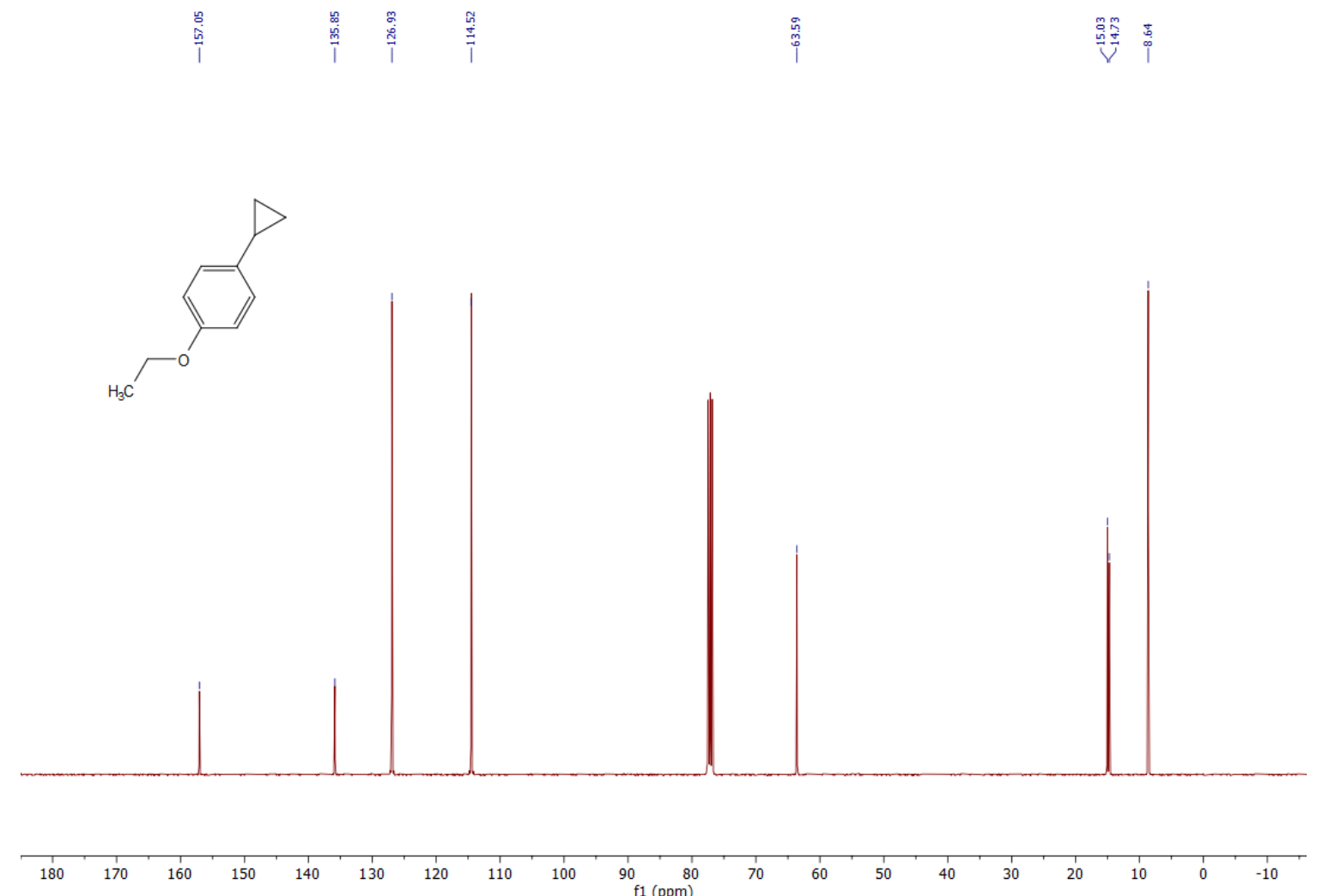

Page | 54 
${ }^{1} \mathrm{H}-\mathrm{NMR}\left(400 \mathrm{MHz}, \mathrm{CDCl}_{3}\right.$ ) (1f)

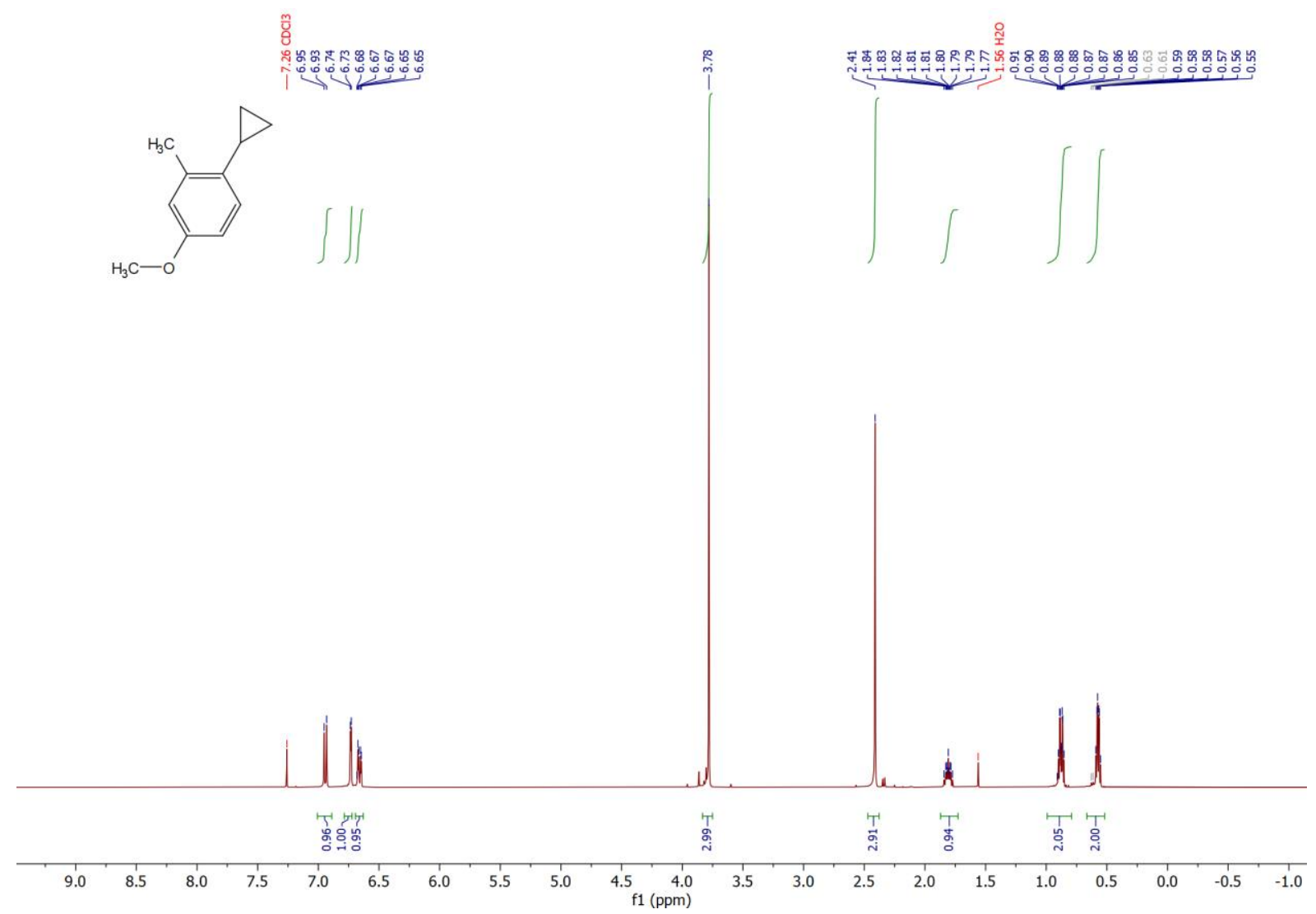

${ }^{13} \mathrm{C}$ NMR (101 MHz, $\left.\mathrm{CDCl}_{3}\right)(1 \mathrm{f})$
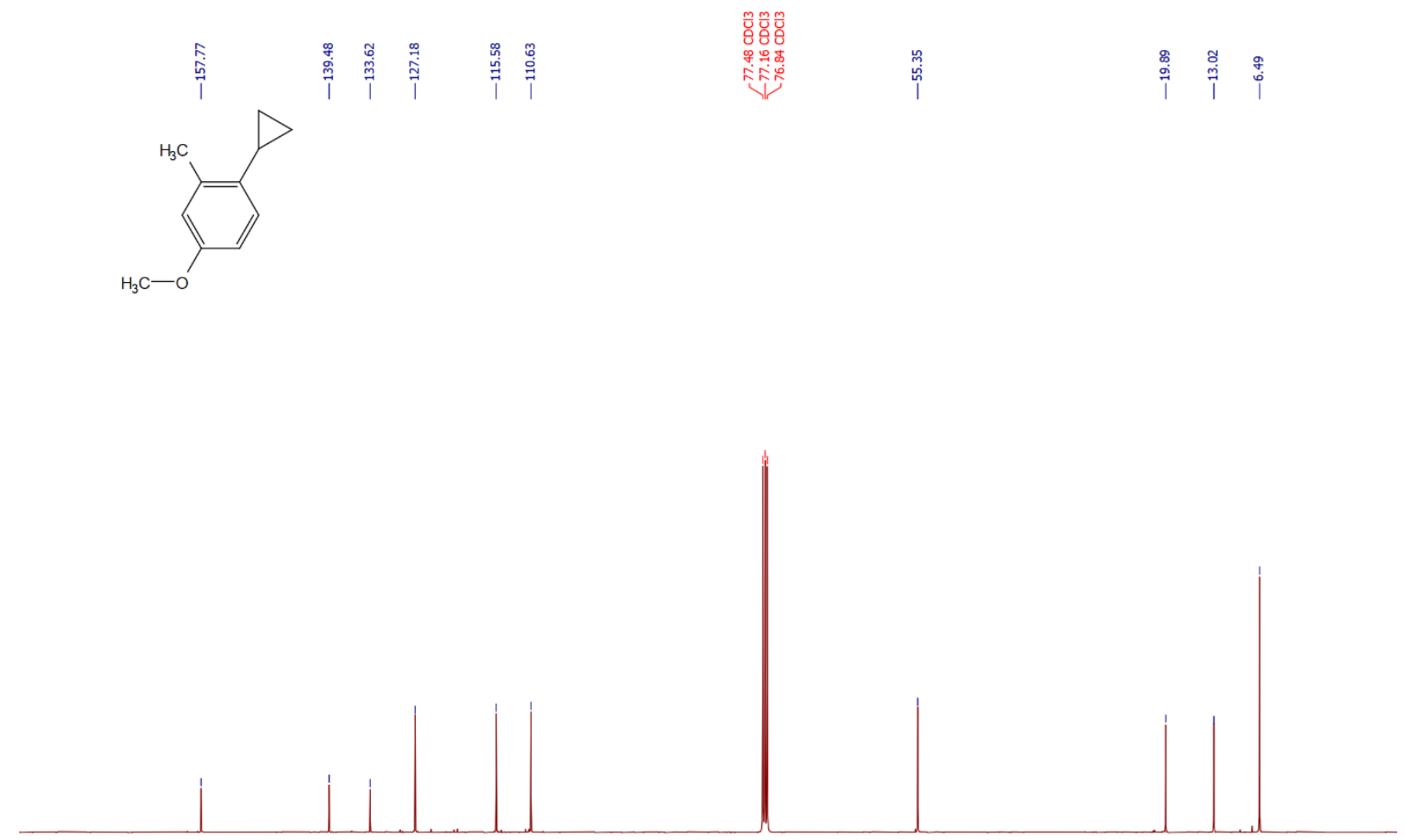

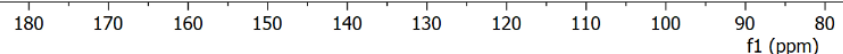


${ }^{1} \mathrm{H}-\mathrm{NMR}\left(400 \mathrm{MHz}, \mathrm{CDCl}_{3}\right)$ (1f)

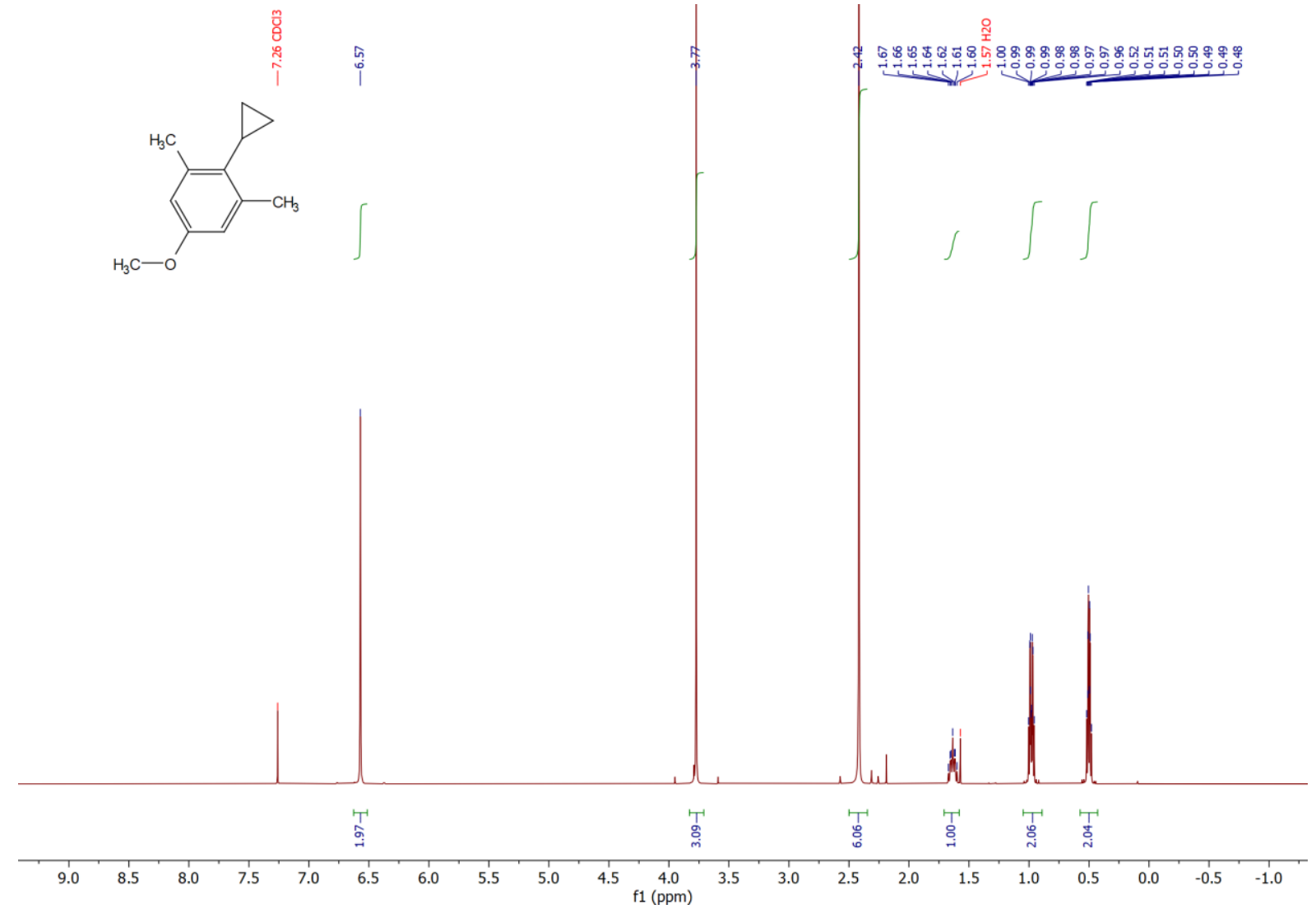

${ }^{13} \mathrm{C}$ NMR (101 MHz, $\left.\mathrm{CDCl}_{3}\right)(1 \mathrm{f})$
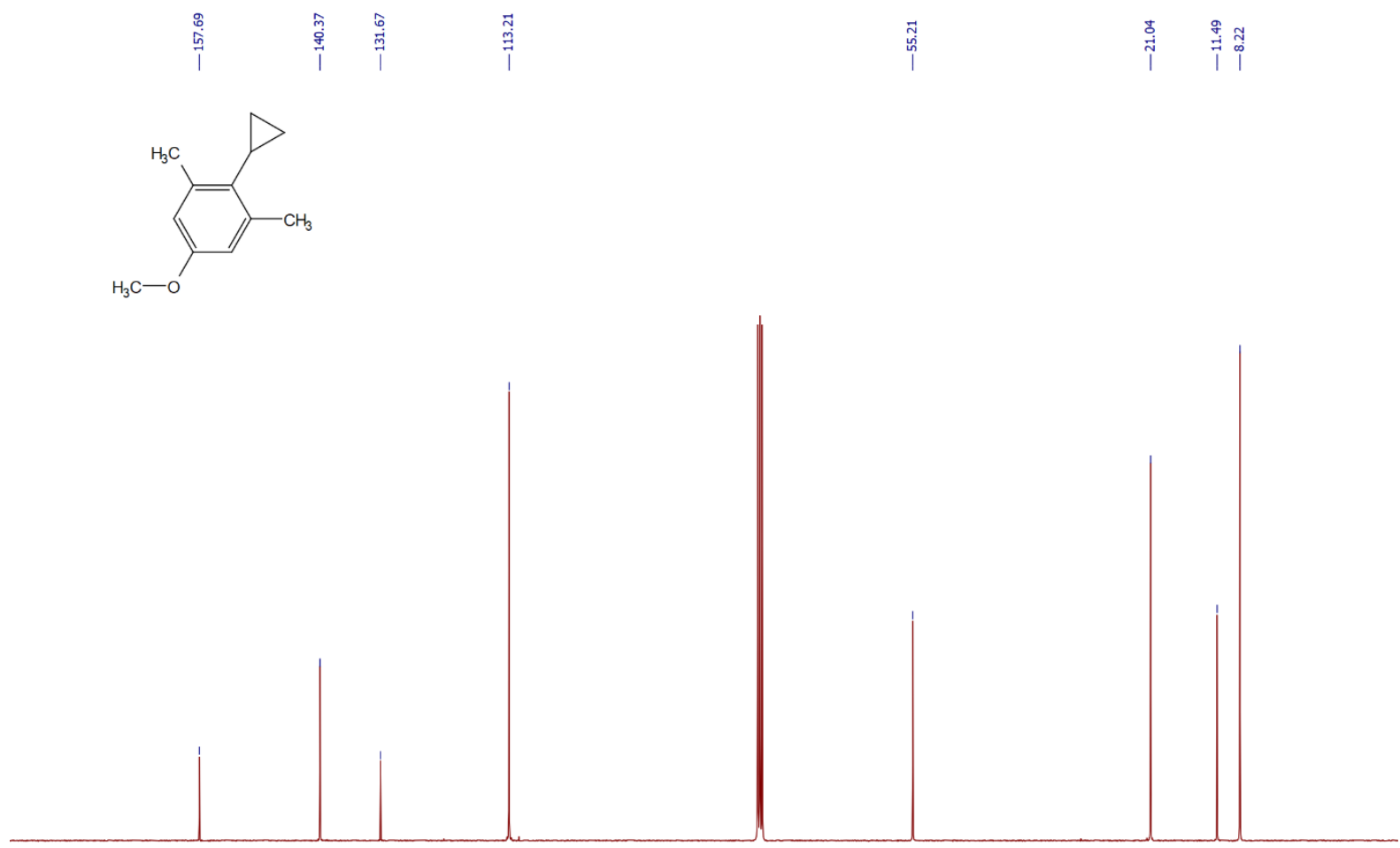

$\begin{array}{llllllllll}180 & 170 & 160 & 150 & 140 & 130 & 120 & 110 & 100 & 90 \\ \mathrm{f} 1(\mathrm{ppm})\end{array}$

\begin{tabular}{|c|c|c|c|c|c|c|c|c|}
\hline 70 & 60 & 50 & 40 & 30 & 20 & 10 & 0 & -10 \\
\hline
\end{tabular}


${ }^{1} \mathrm{H}-\mathrm{NMR}\left(400 \mathrm{MHz}, \mathrm{CDCl}_{3}\right)$ (1g)

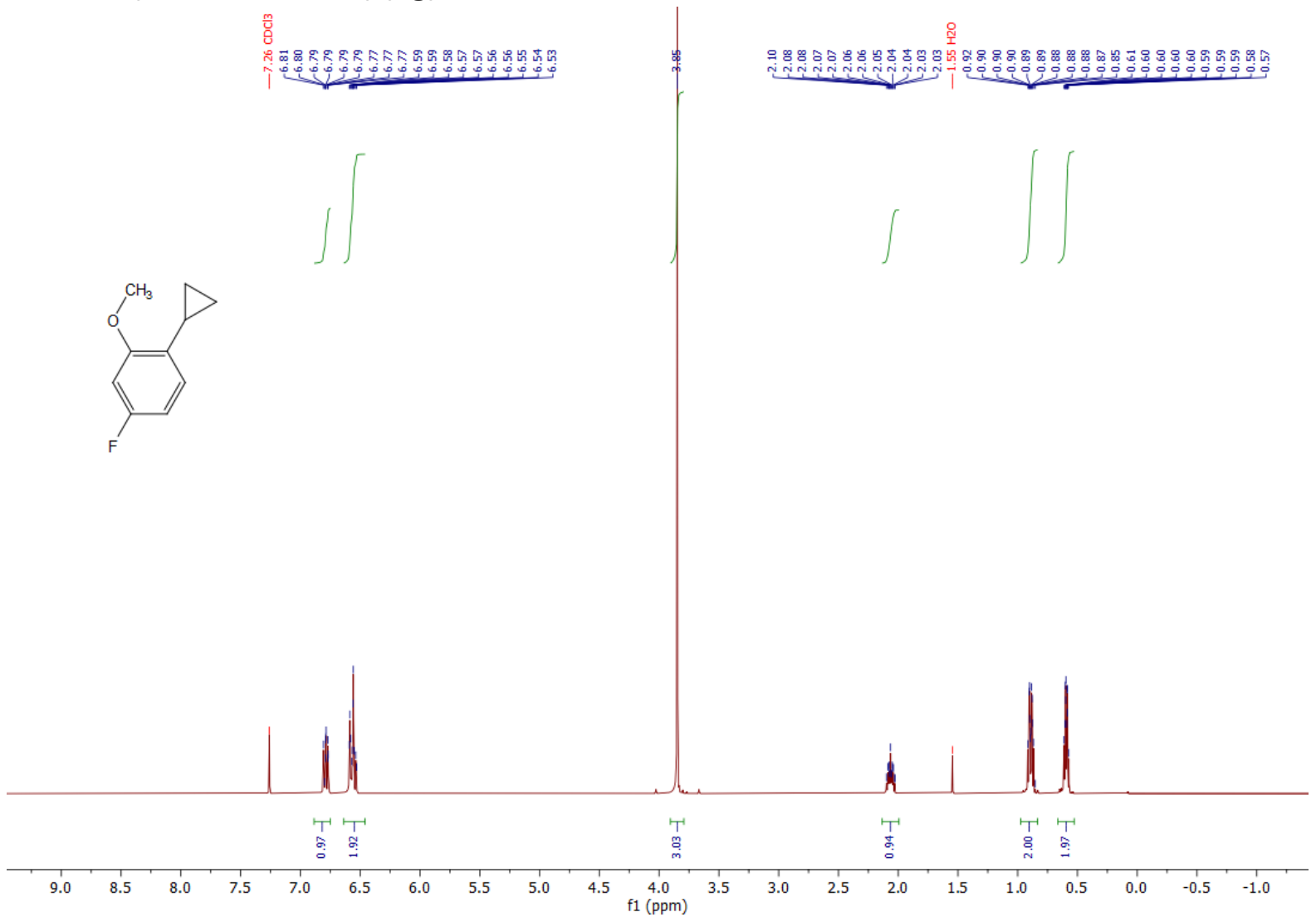

${ }^{13} \mathrm{C}$ NMR (101 MHz, $\left.\mathrm{CDCl}_{3}\right)(1 \mathrm{~g})$

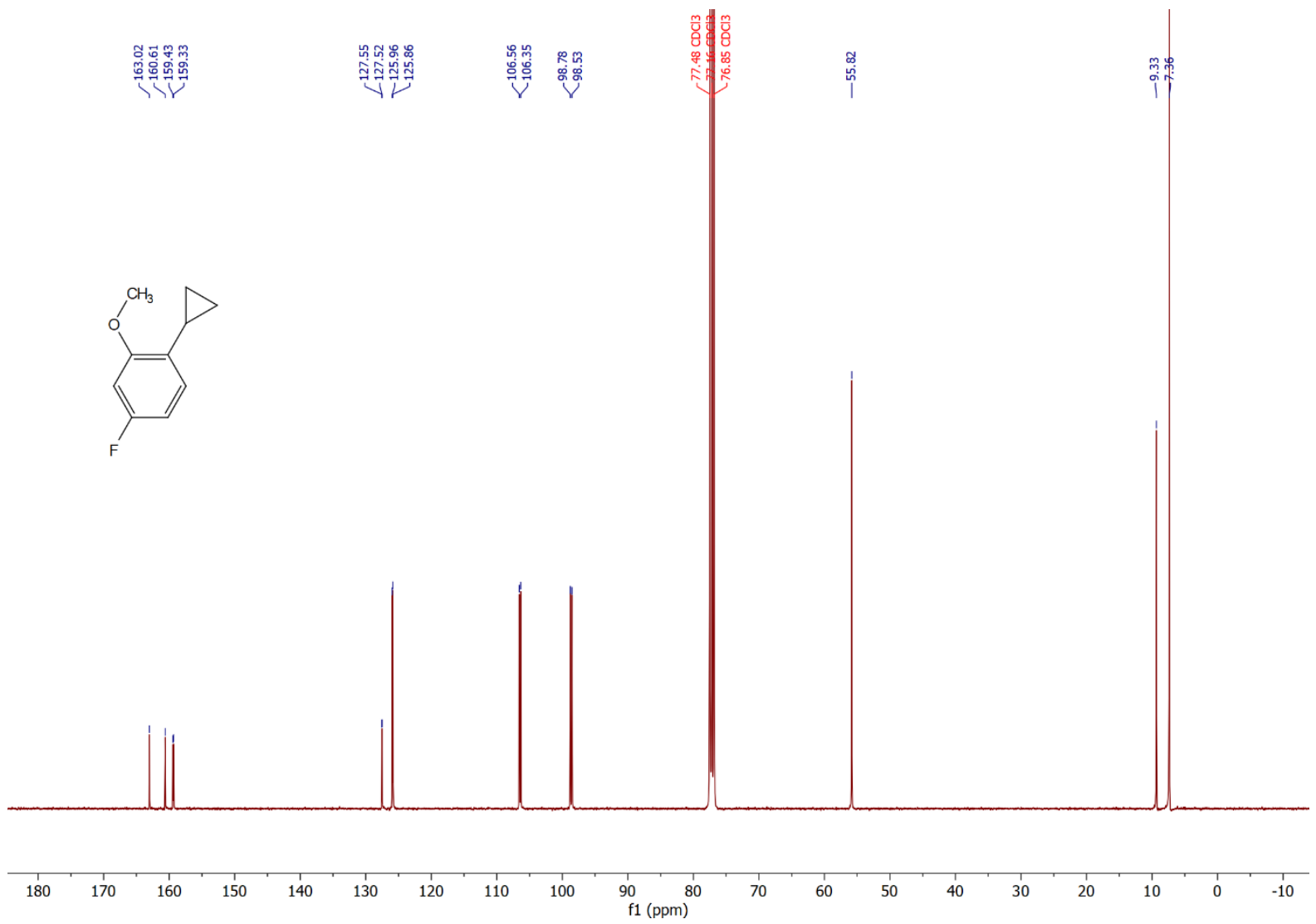


${ }^{19} \mathrm{~F}$ NMR (377 MHz, $\left.\mathrm{CDCl}_{3}\right)(1 \mathrm{~h})$
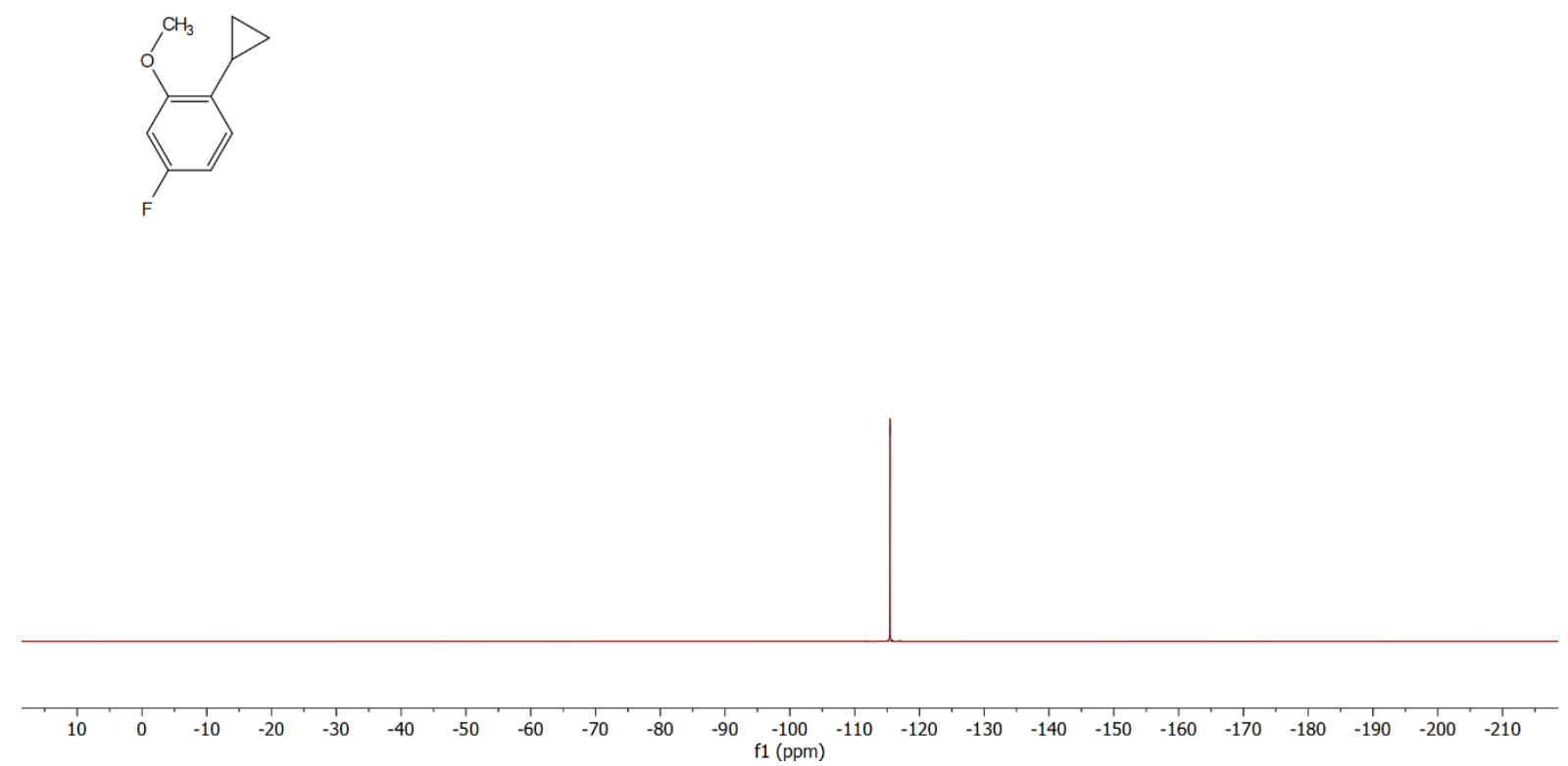

${ }^{1} \mathrm{H}-\mathrm{NMR}\left(400 \mathrm{MHz}, \mathrm{CDCl}_{3}\right)(2 \mathrm{~g})$
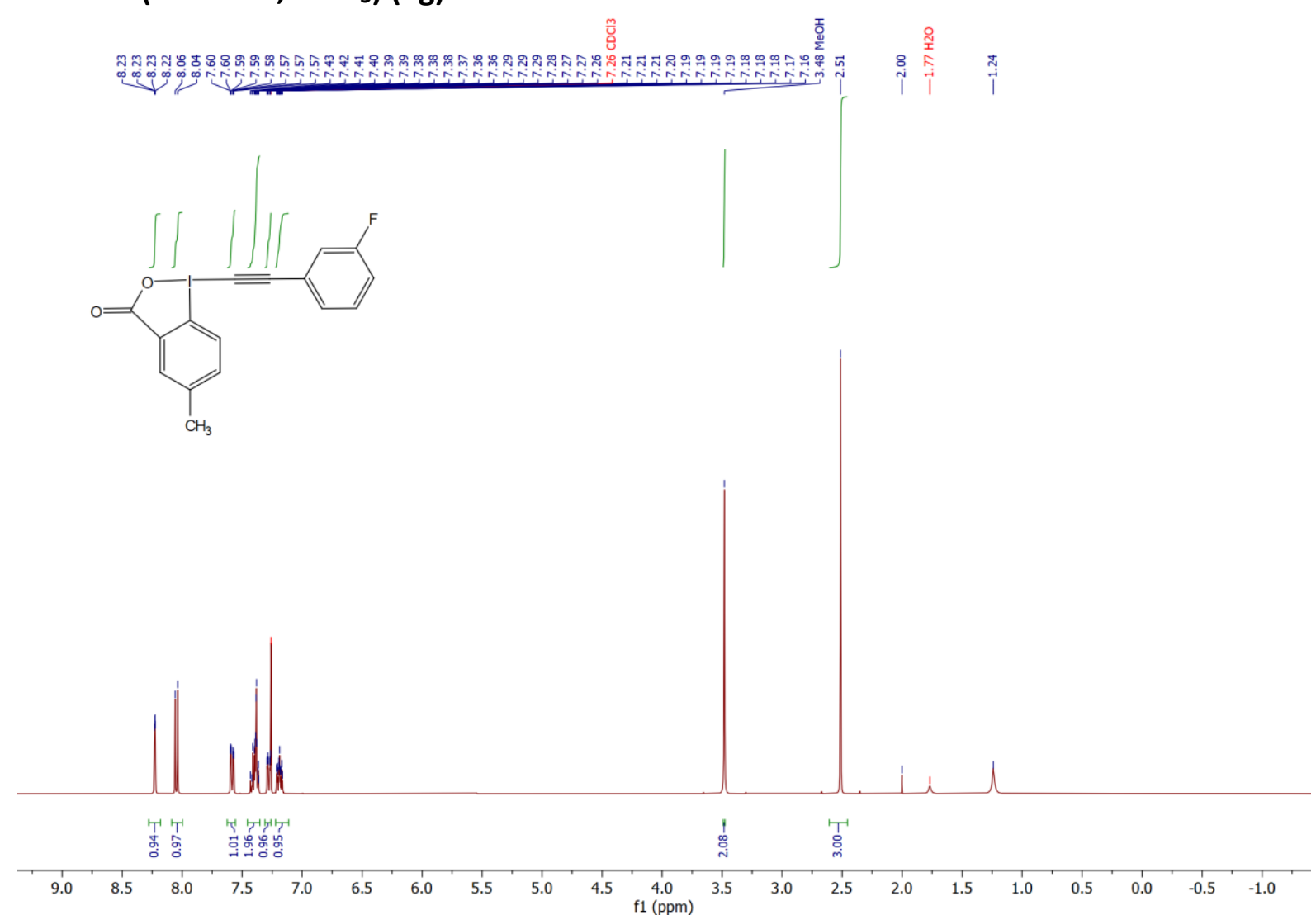
${ }^{13} \mathrm{C}$ NMR (101 MHz, $\mathrm{CDCl}_{3}$ ) (2g)

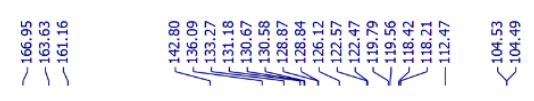

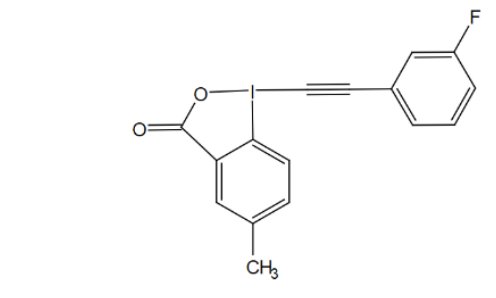

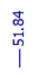

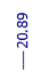
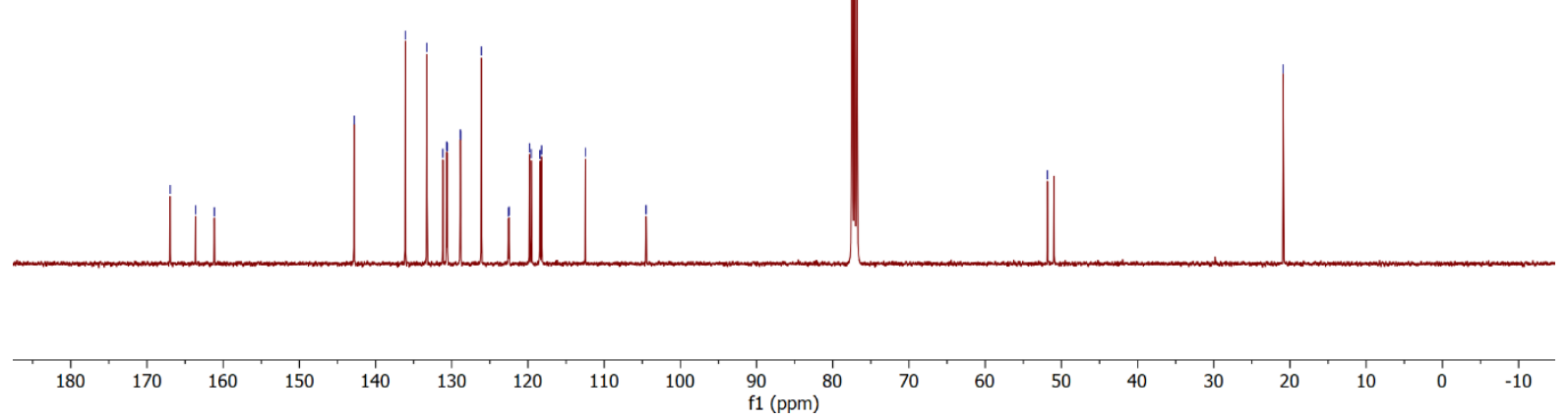

${ }^{19}$ F NMR (377 MHz, $\left.\mathrm{CDCl}_{3}\right)(2 \mathrm{~g})$
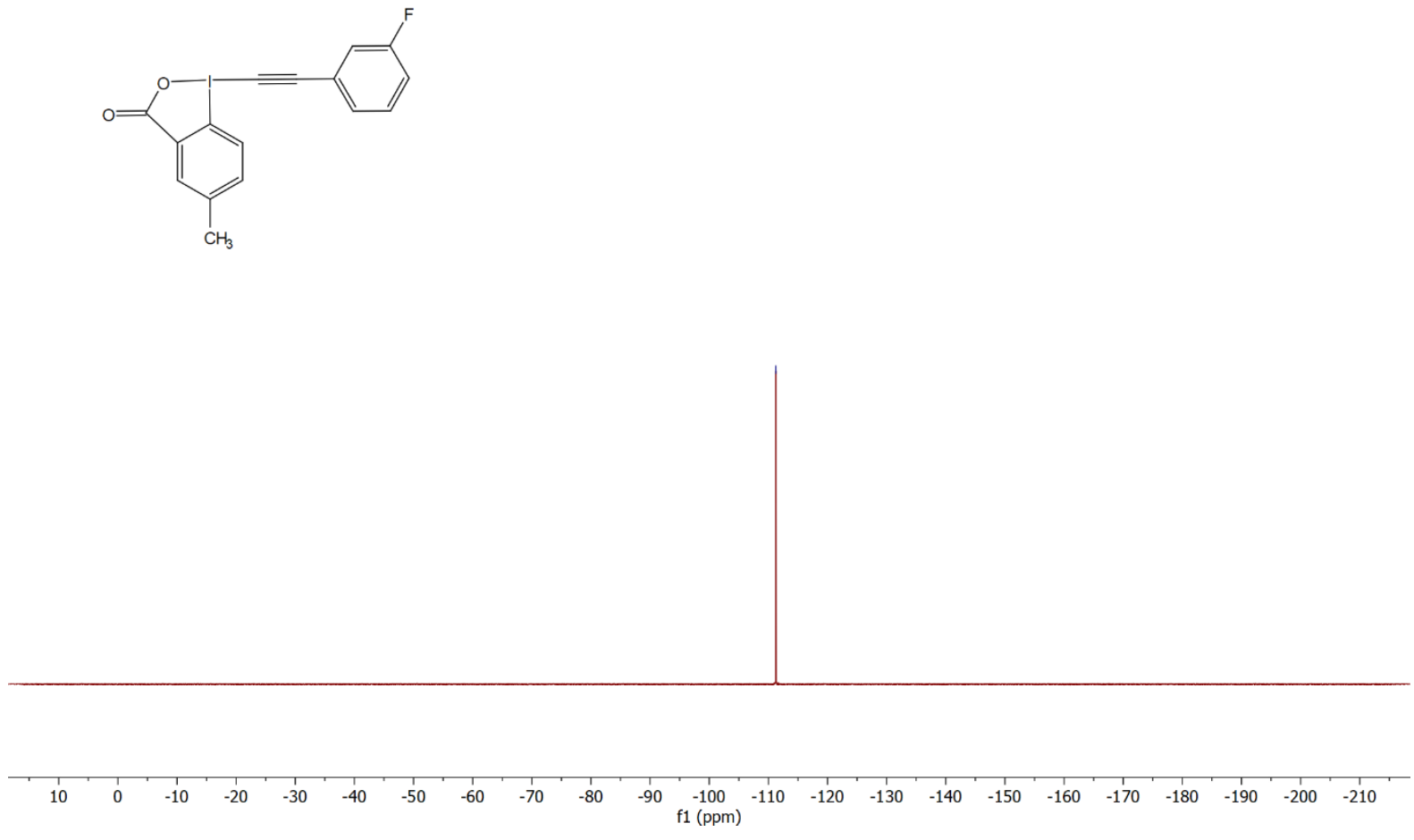

Page | 59 
${ }^{1} \mathrm{H}$ NMR (400 MHz, $\mathrm{CDCl}_{3}$ ) (3a)
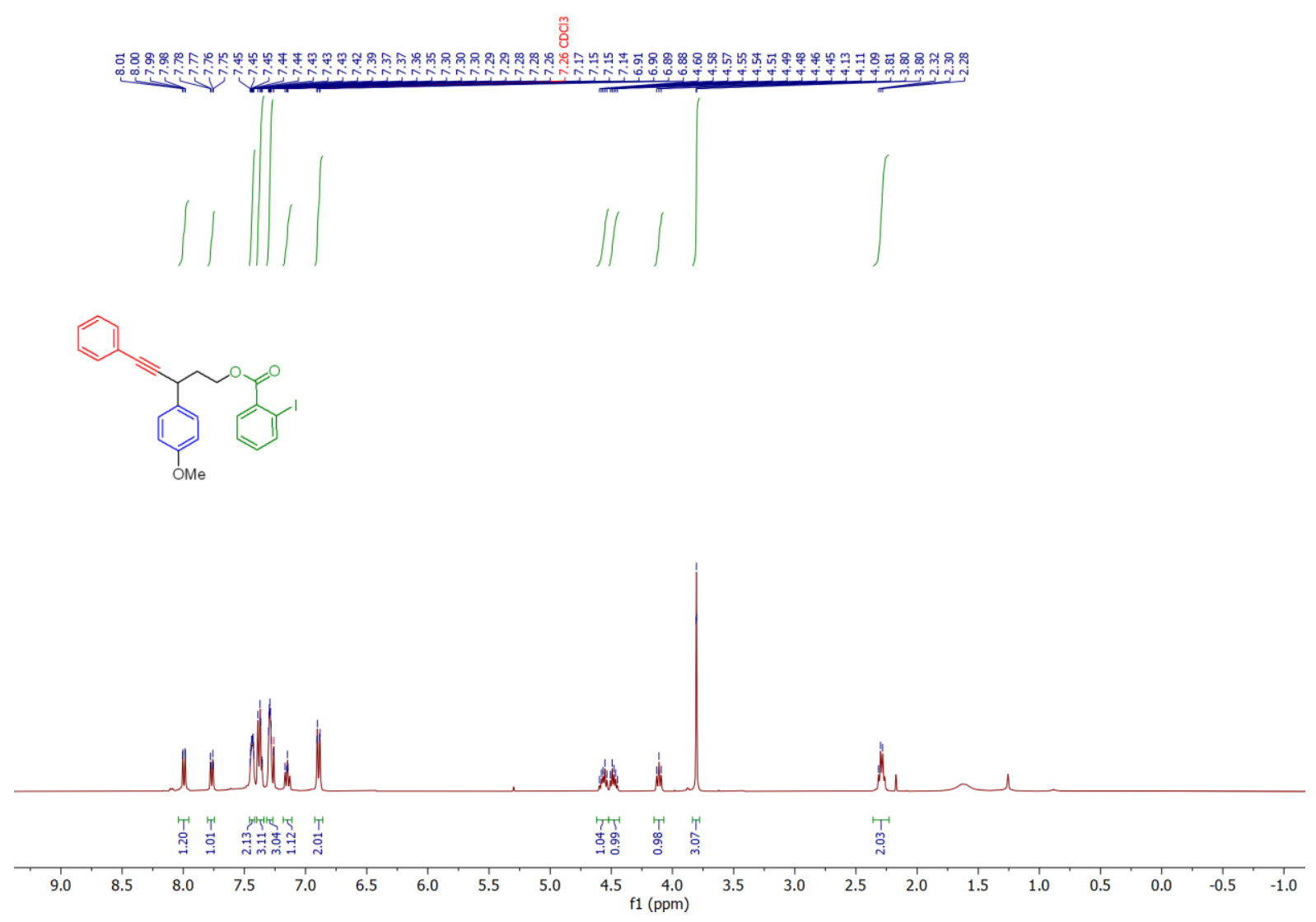

${ }^{13} \mathrm{C}$ NMR (101 MHz, $\mathrm{CDCl}_{3}$ ) (3a)

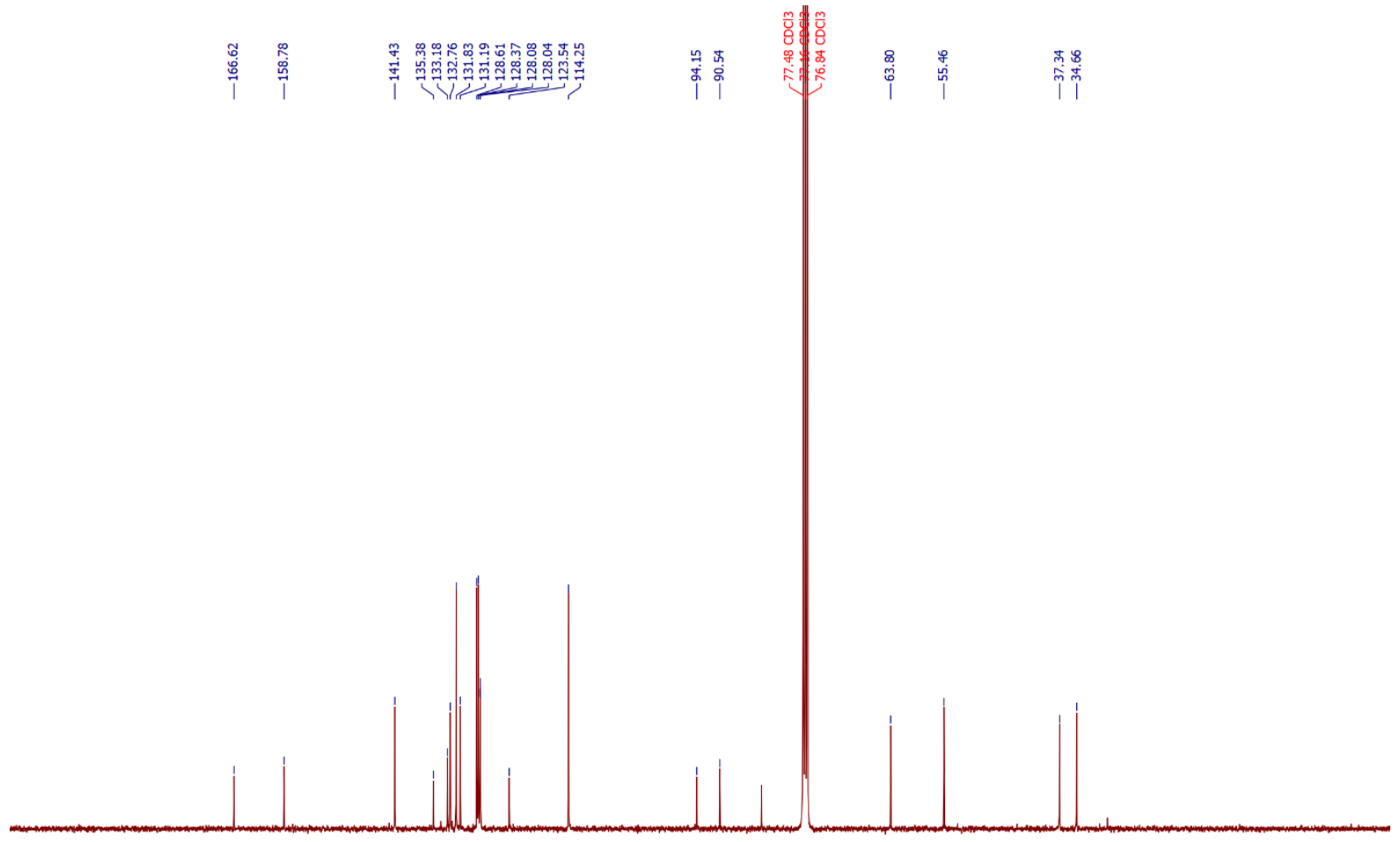

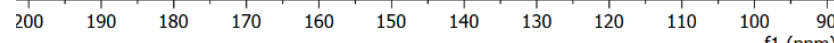


${ }^{1} \mathbf{H}$ NMR (400 MHz, $\left.\mathrm{CDCl}_{3}\right)$ (Bb)

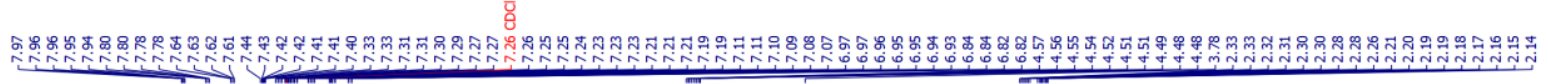
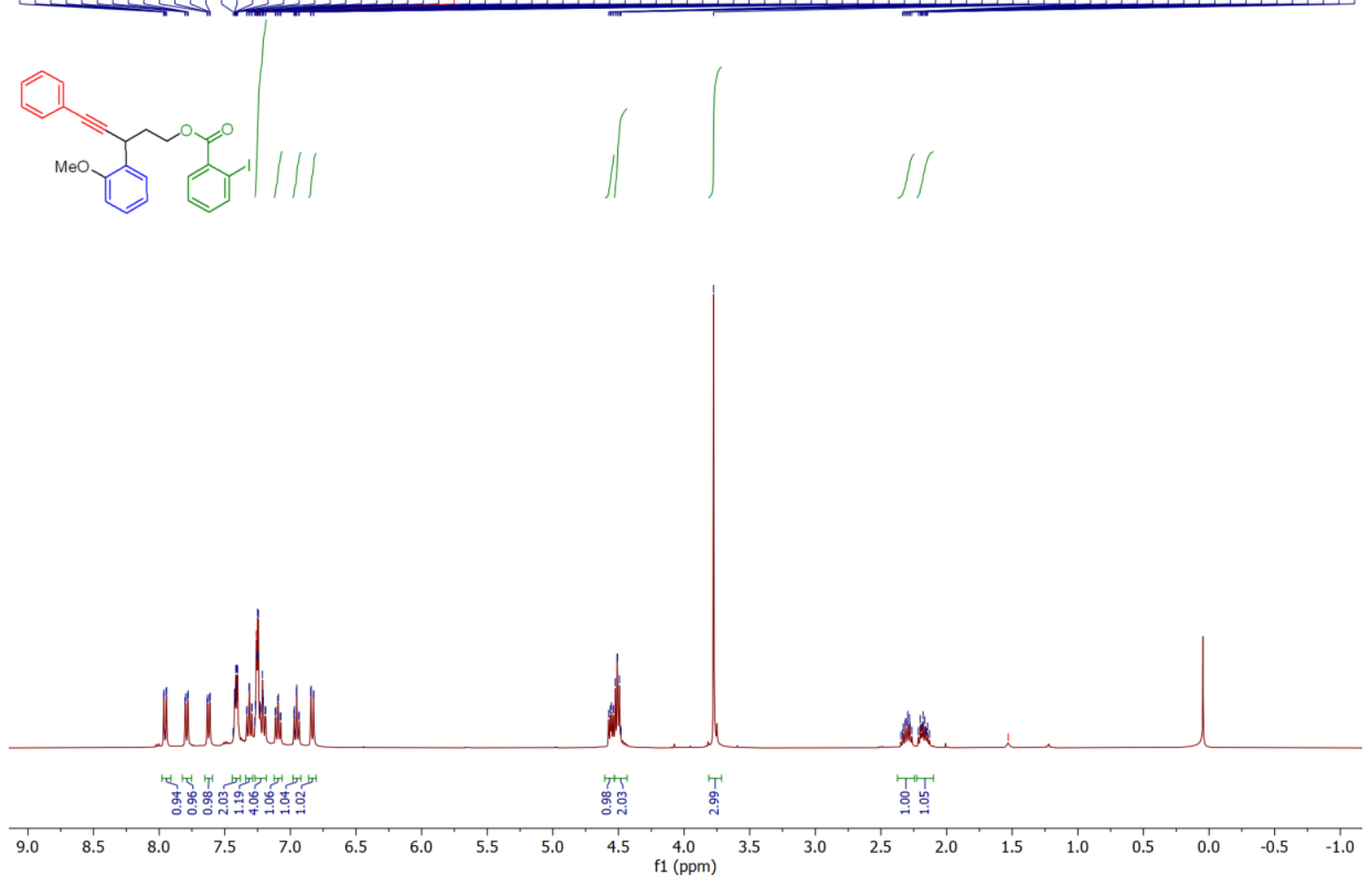

${ }^{13} \mathrm{C}$ NMR (101 MHz, $\left.\mathrm{CDCl}_{3}\right)(3 \mathrm{~b})$
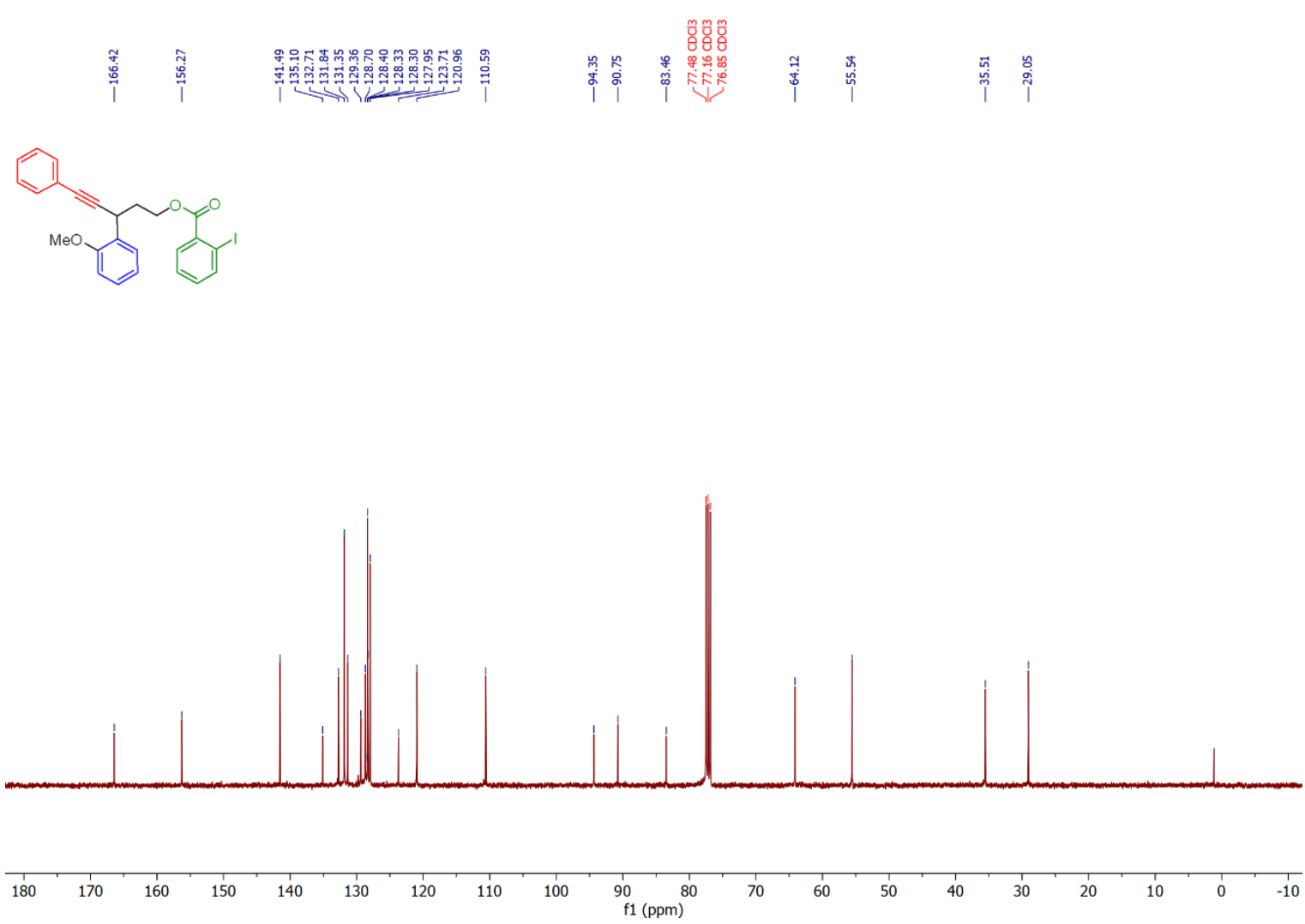

Page | 61 
${ }^{1} \mathbf{H}$ NMR (400 MHz, $\left.\mathrm{CDCl}_{3}\right)$ (3c)

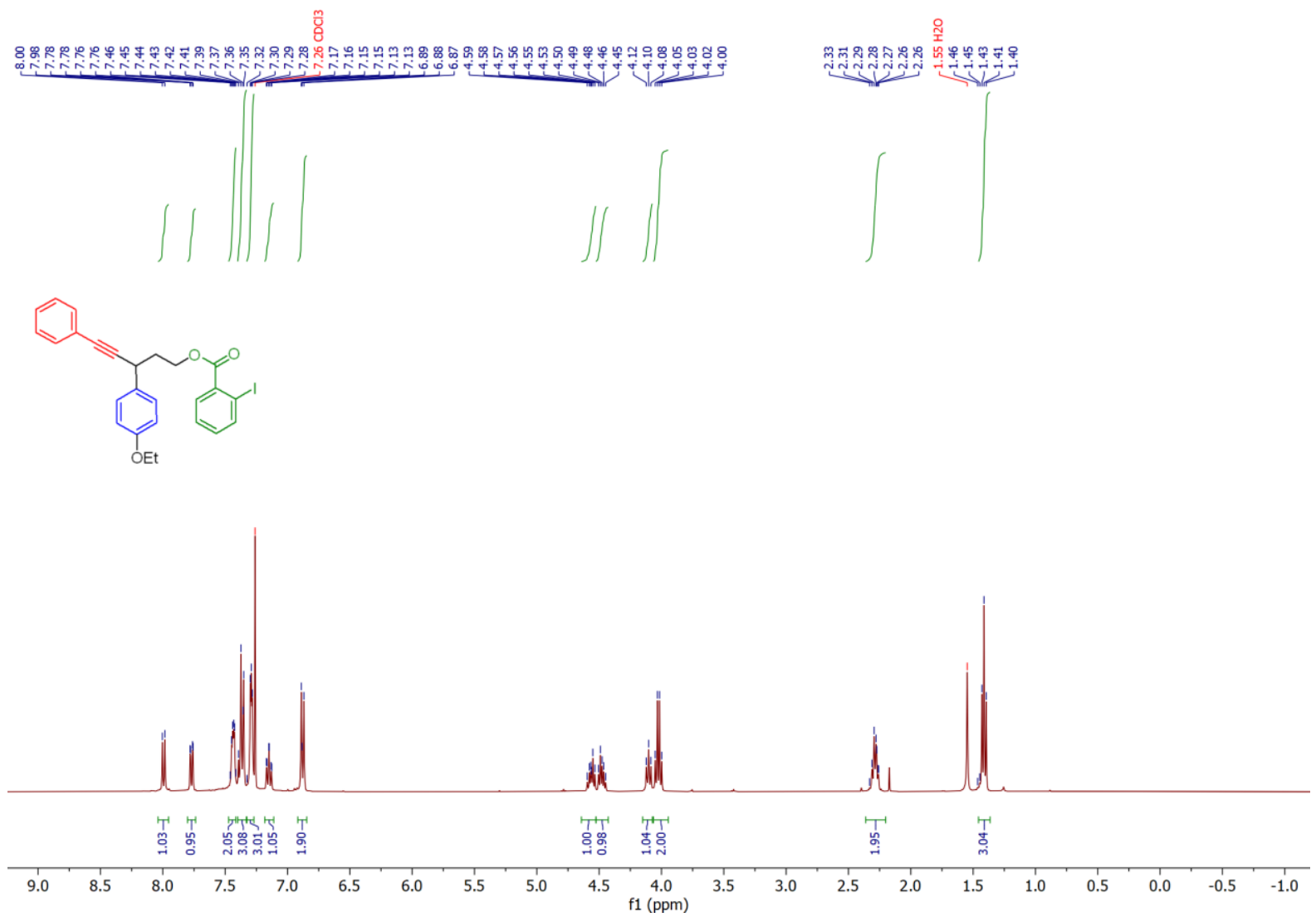

${ }^{13} \mathrm{C}$ NMR $\left(101 \mathrm{MHz}, \mathrm{CDCl}_{3}\right)(3 \mathrm{c})$

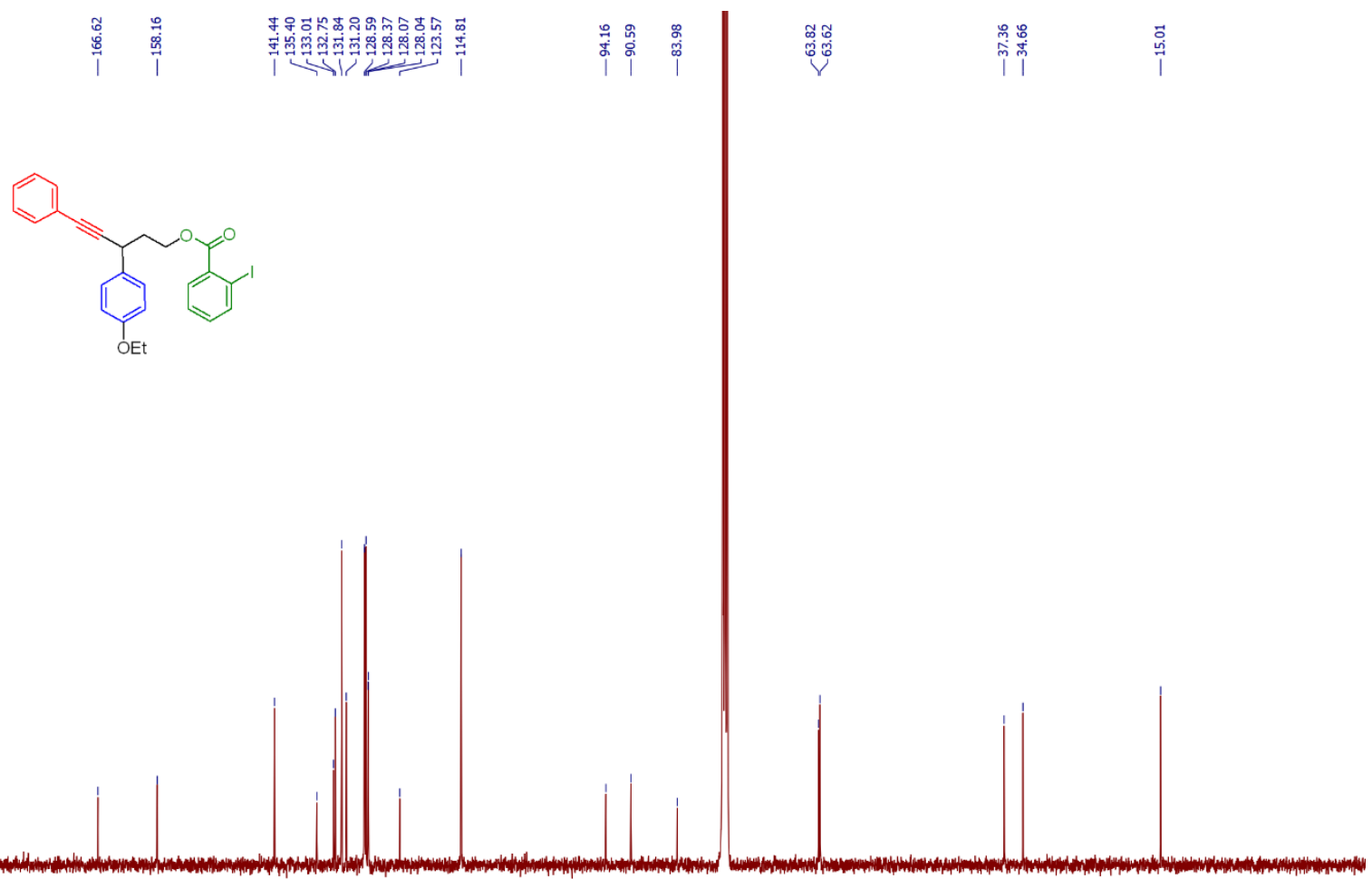

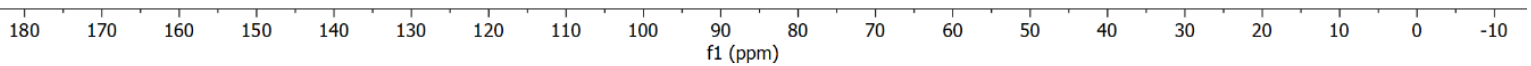


${ }^{1} \mathrm{H}$ NMR (400 MHz, $\left.\mathrm{CDCl}_{3}\right)$ (3d)

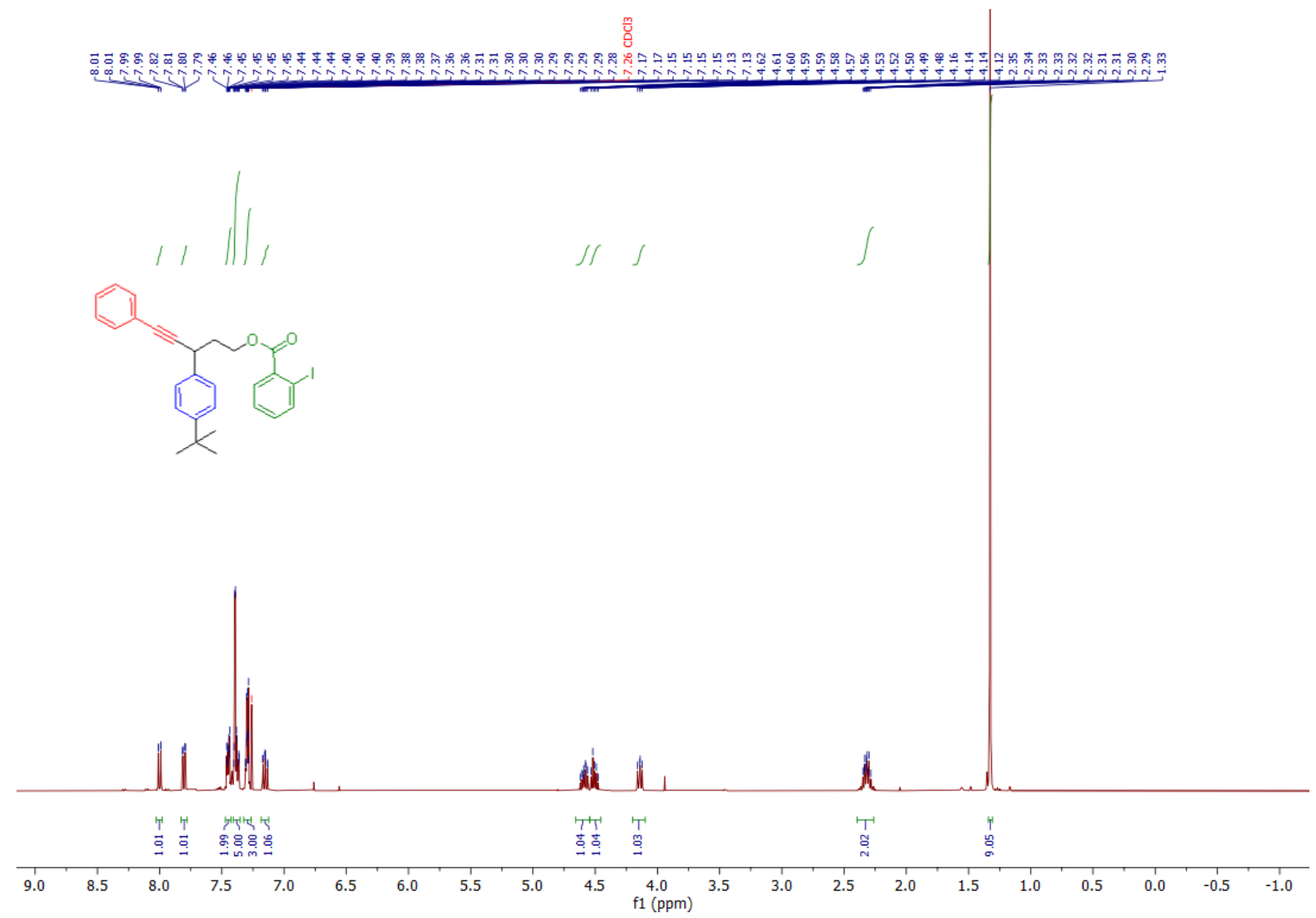

${ }^{13} \mathrm{C}$ NMR (101 MHz, $\left.\mathrm{CDCl}_{3}\right)$ (3d)

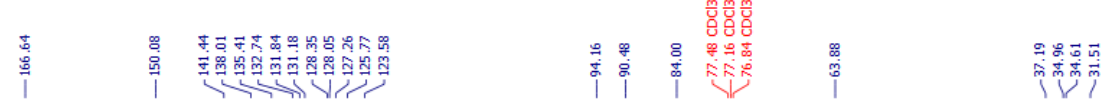
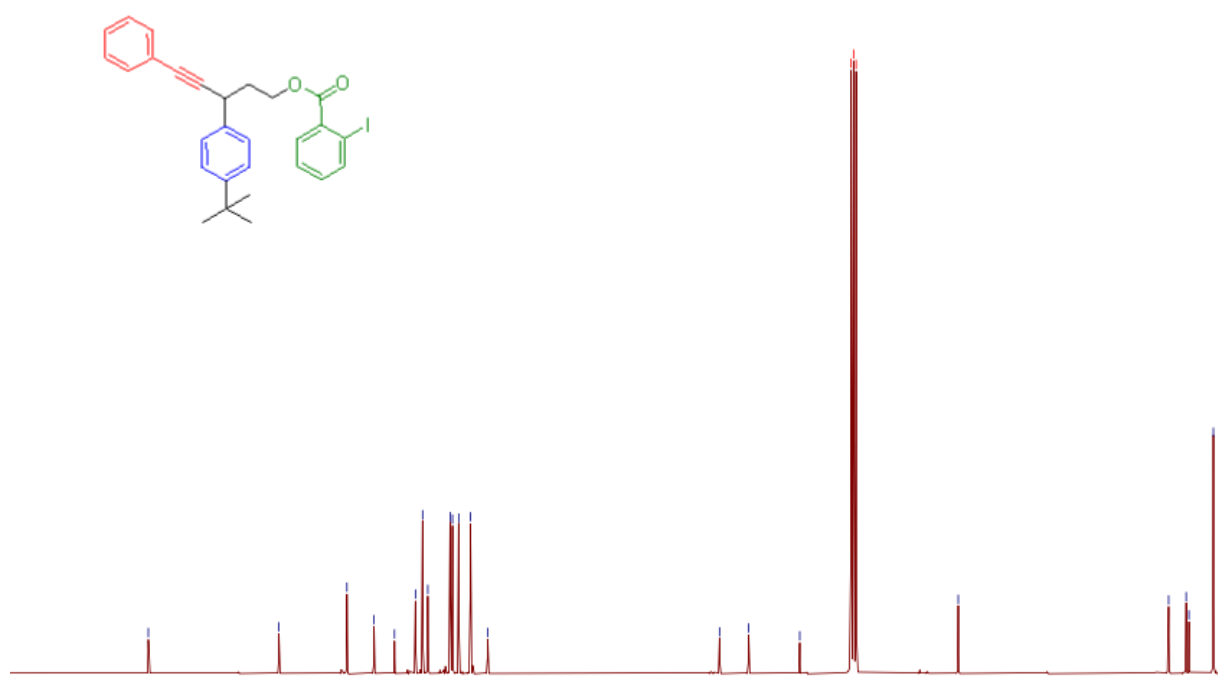

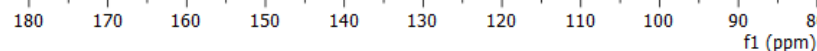


${ }^{1} \mathrm{H}$ NMR (400 MHz, $\left.\mathrm{CDCl}_{3}\right)$ (3e)
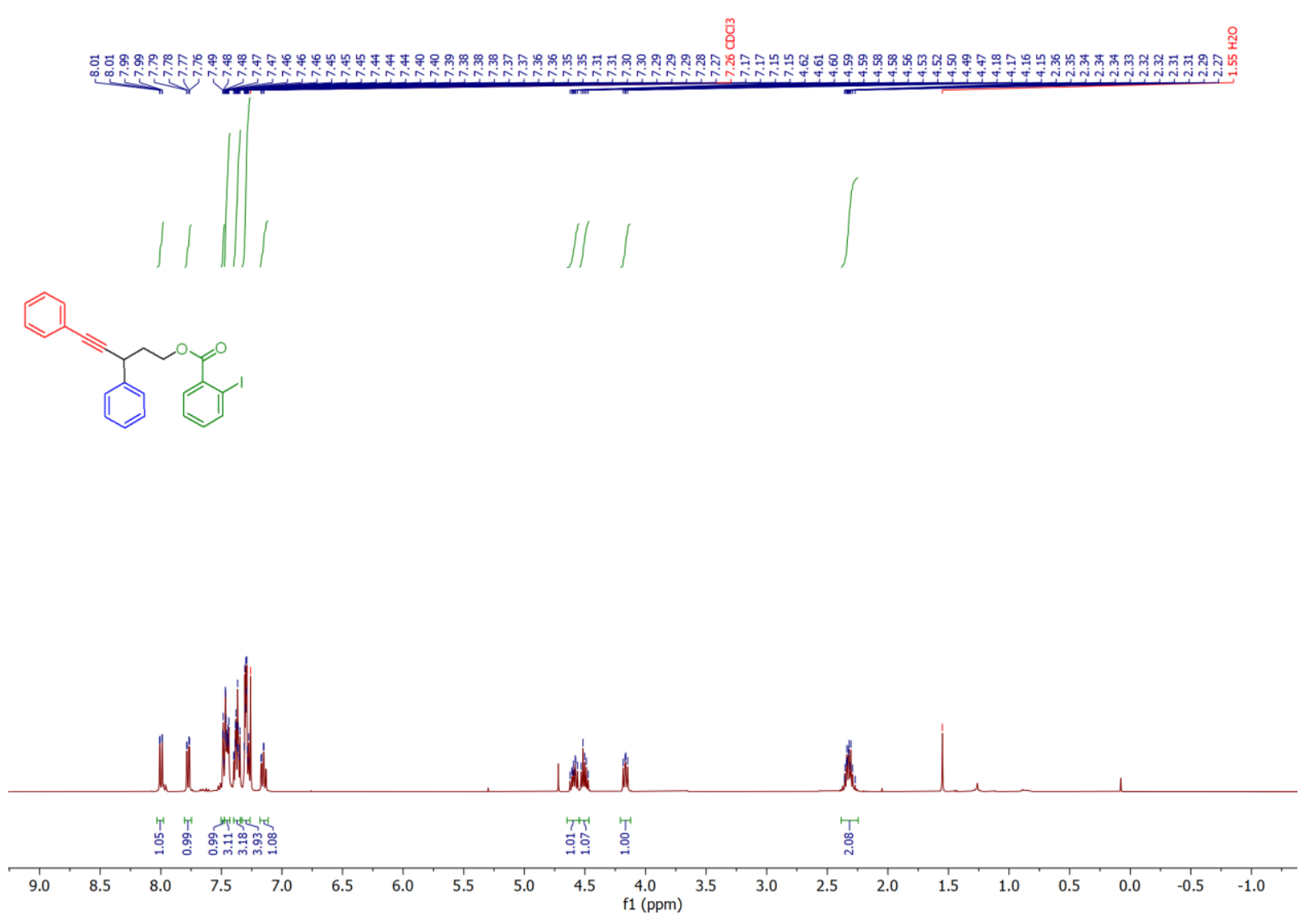

${ }^{13}$ C NMR (101 MHz, $\left.\mathrm{CDCl}_{3}\right)$ : (3e)
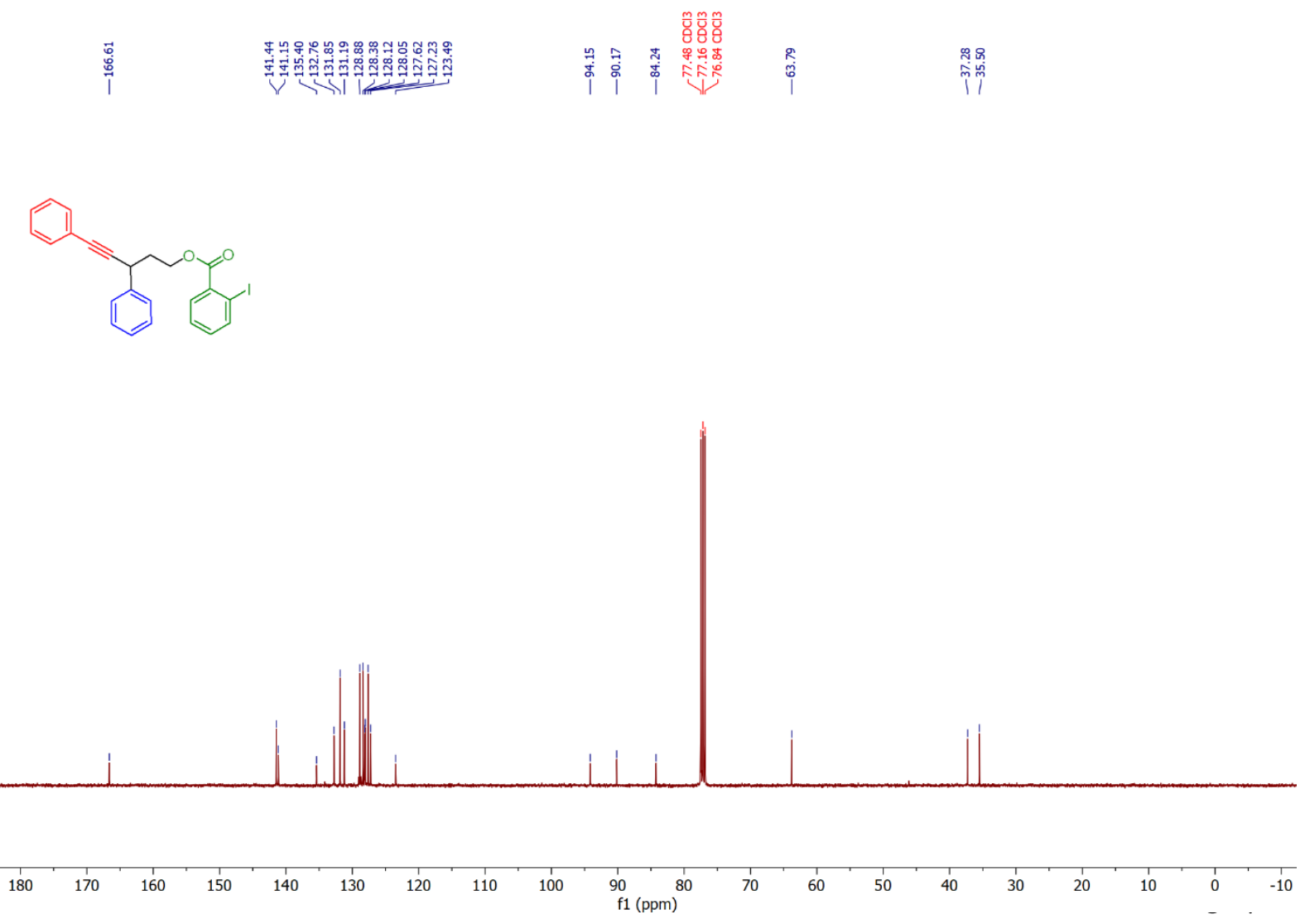
${ }^{1} \mathbf{H}$ NMR (400 MHz, $\mathrm{CDCl}_{3}$ ) (Bf)

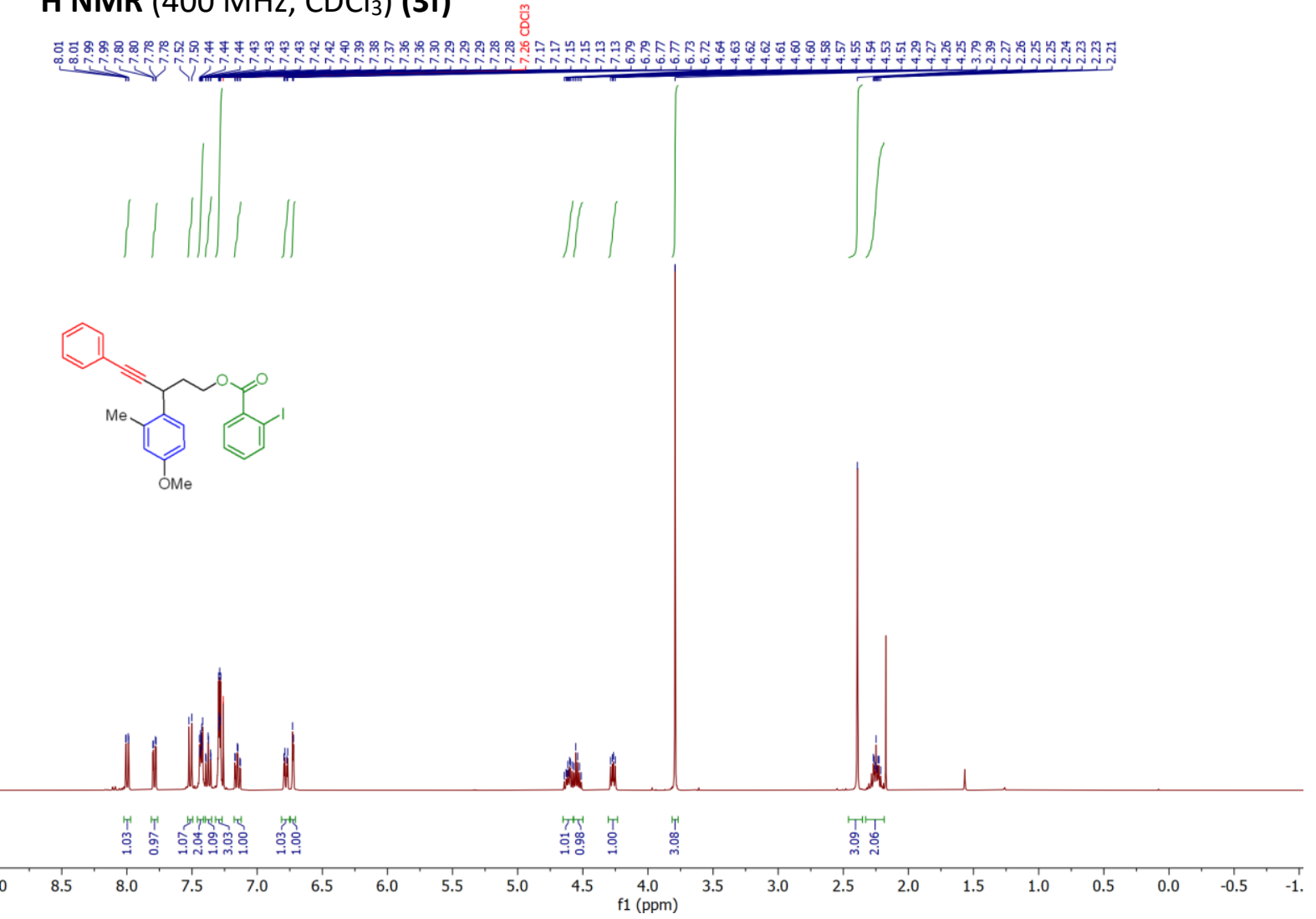

${ }^{13} \mathrm{C}$ NMR (101 MHz, $\mathrm{CDCl}_{3}$ ) (3f)

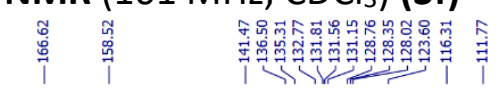

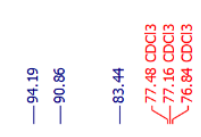
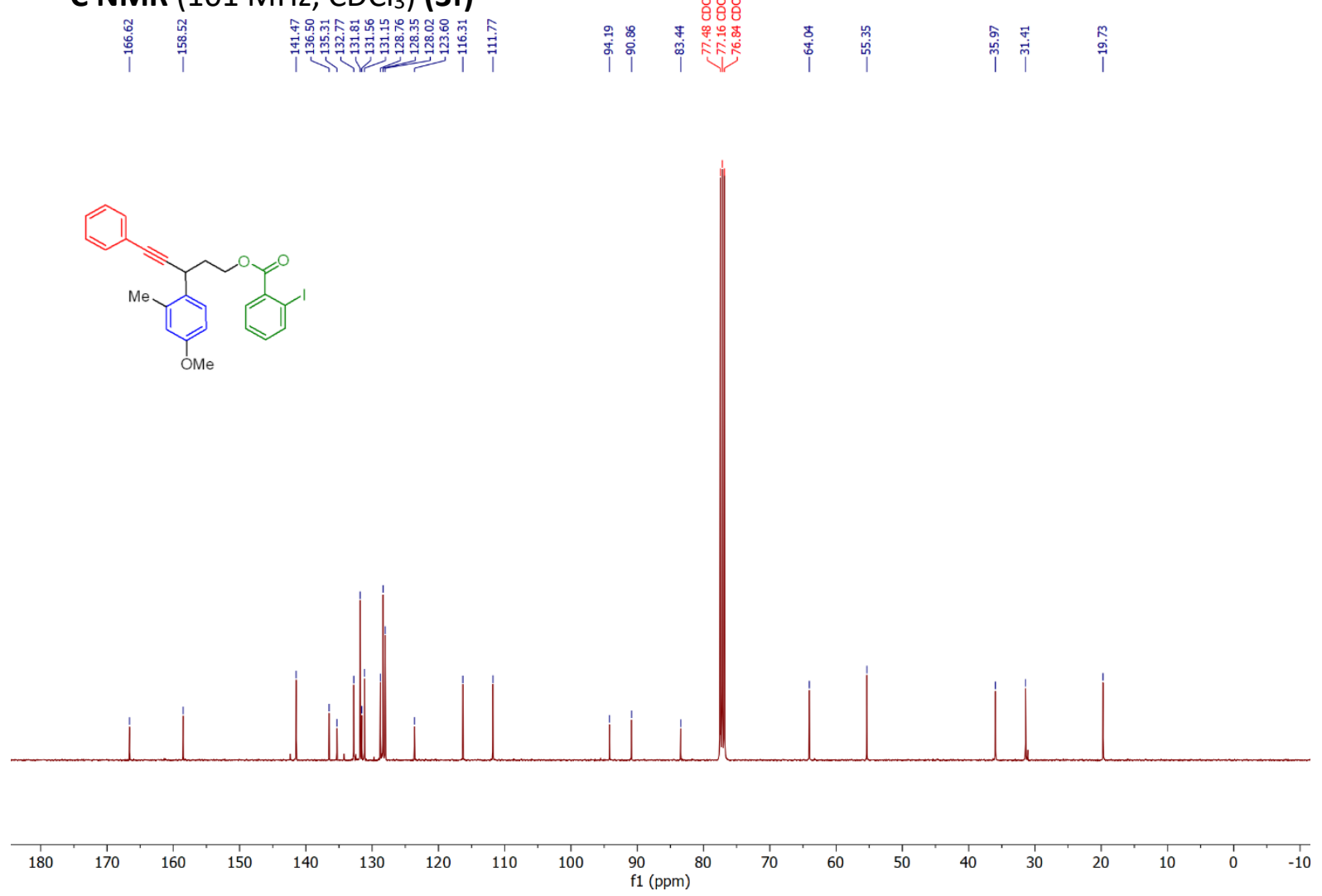

Page | 65 
${ }^{1} \mathbf{H}$ NMR (400 MHz, $\mathrm{CDCl}_{3}$ ) (3h)

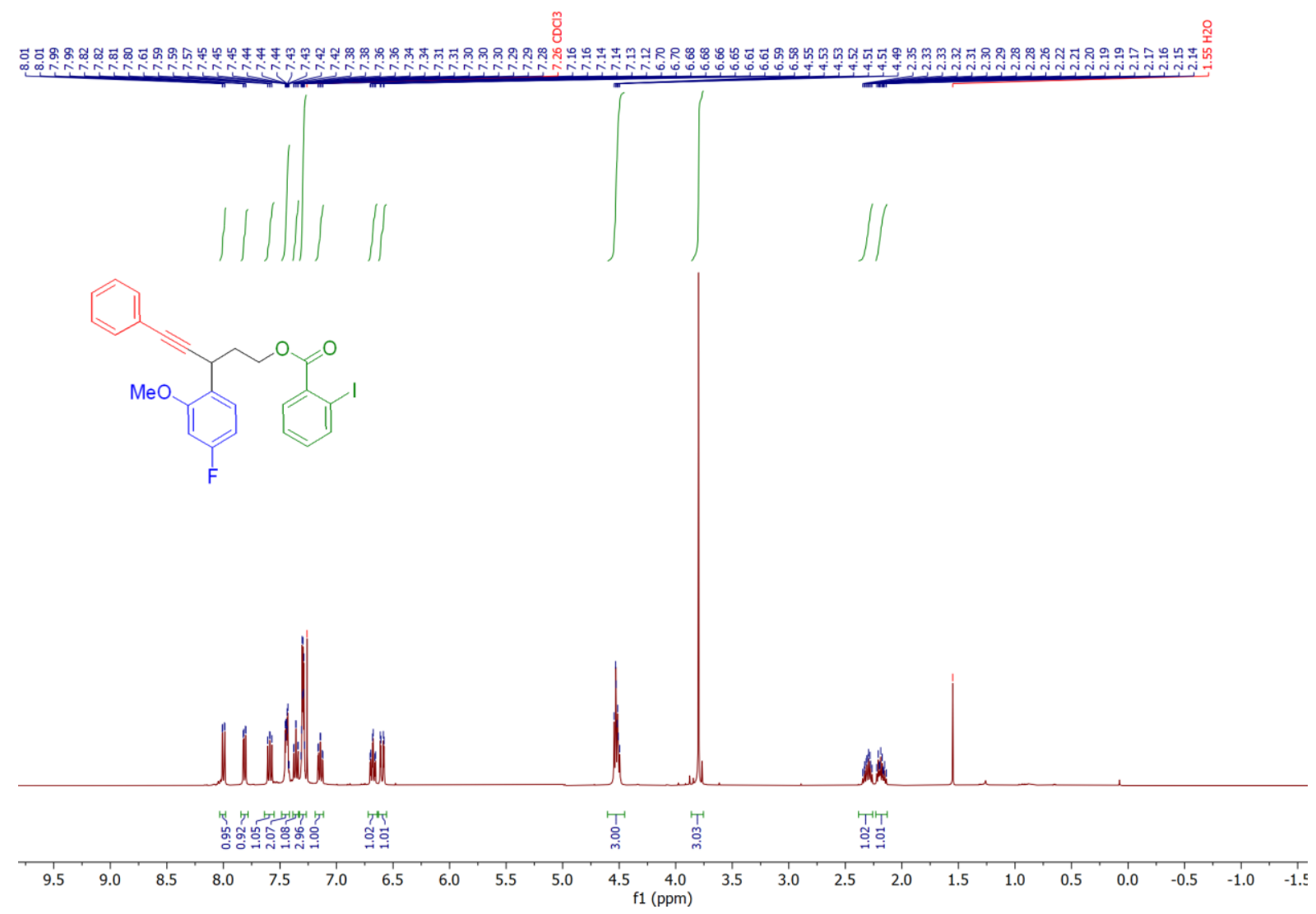

${ }^{13} \mathrm{C} \mathrm{NMR}\left(151 \mathrm{MHz}, \mathrm{CDCl}_{3}\right)(3 \mathrm{~h})$

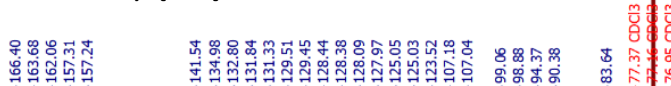

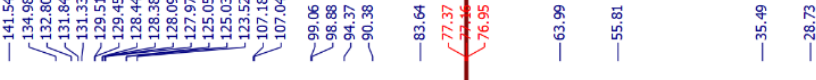
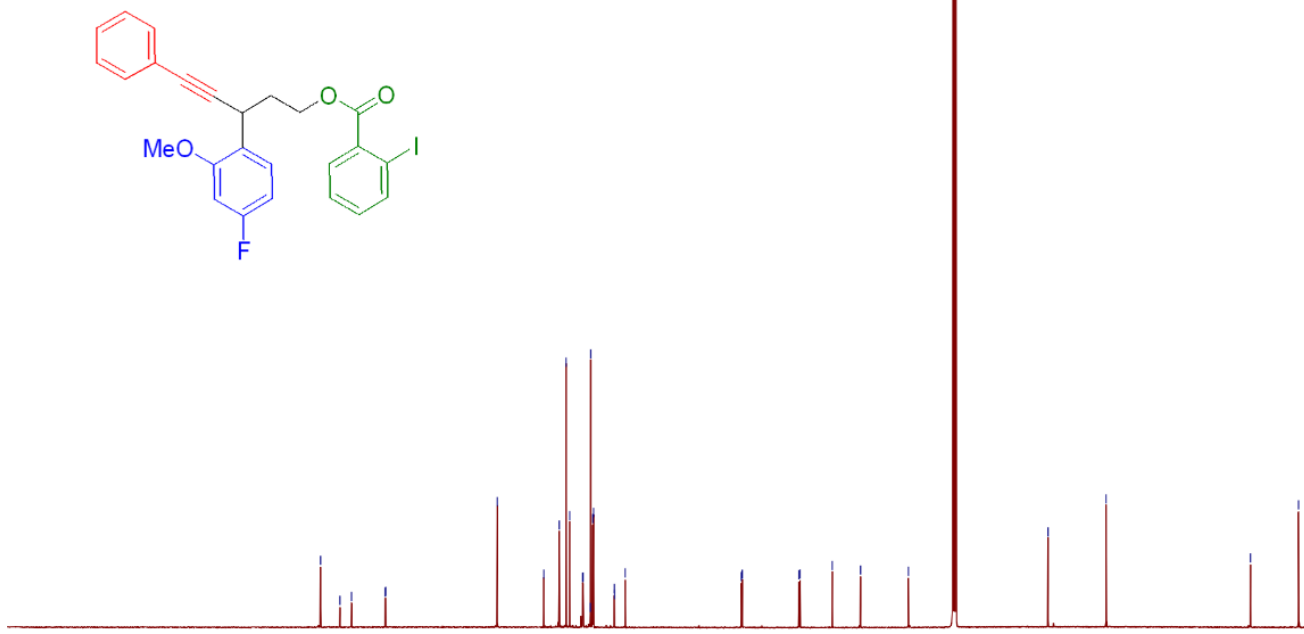

$\begin{array}{llllllllllllllllllllllllll}10 & 200 & 190 & 180 & 170 & 160 & 150 & 140 & 130 & 120 & 110 & 100 & 90 & 80 & 70 & 60 & 50 & 40 & 30 & 20 & 10 & 0 & -1\end{array}$ 
${ }^{19}$ F NMR (376 MHz, $\left.\mathrm{CDCl}_{3}\right)$ (3h)

$$
\stackrel{\grave{\dddot{i}}}{\hat{i}}
$$
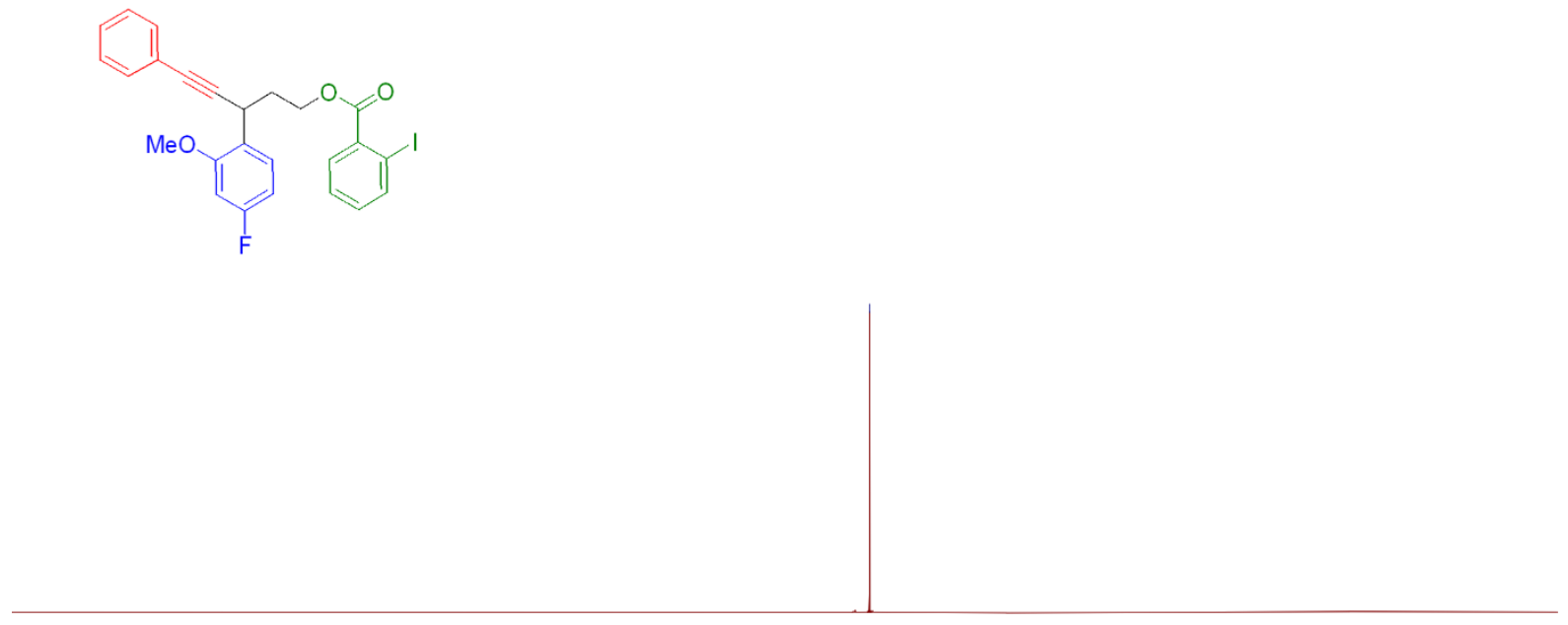

$\begin{array}{llllllllllllllllllllllll}1 & 10 & 0 & -10 & -20 & -30 & -40 & -50 & -60 & -70 & -80 & -90 & -100 & -110 & -120 & -130 & -140 & -150 & -160 & -170 & -180 & -190 & -200 & -210\end{array}$ 
${ }^{1} \mathrm{H}$ NMR (400 MHz, $\mathrm{CDCl}_{3}$ ) (3i) Blue : major diastereomer. Organe : minor diastereomer

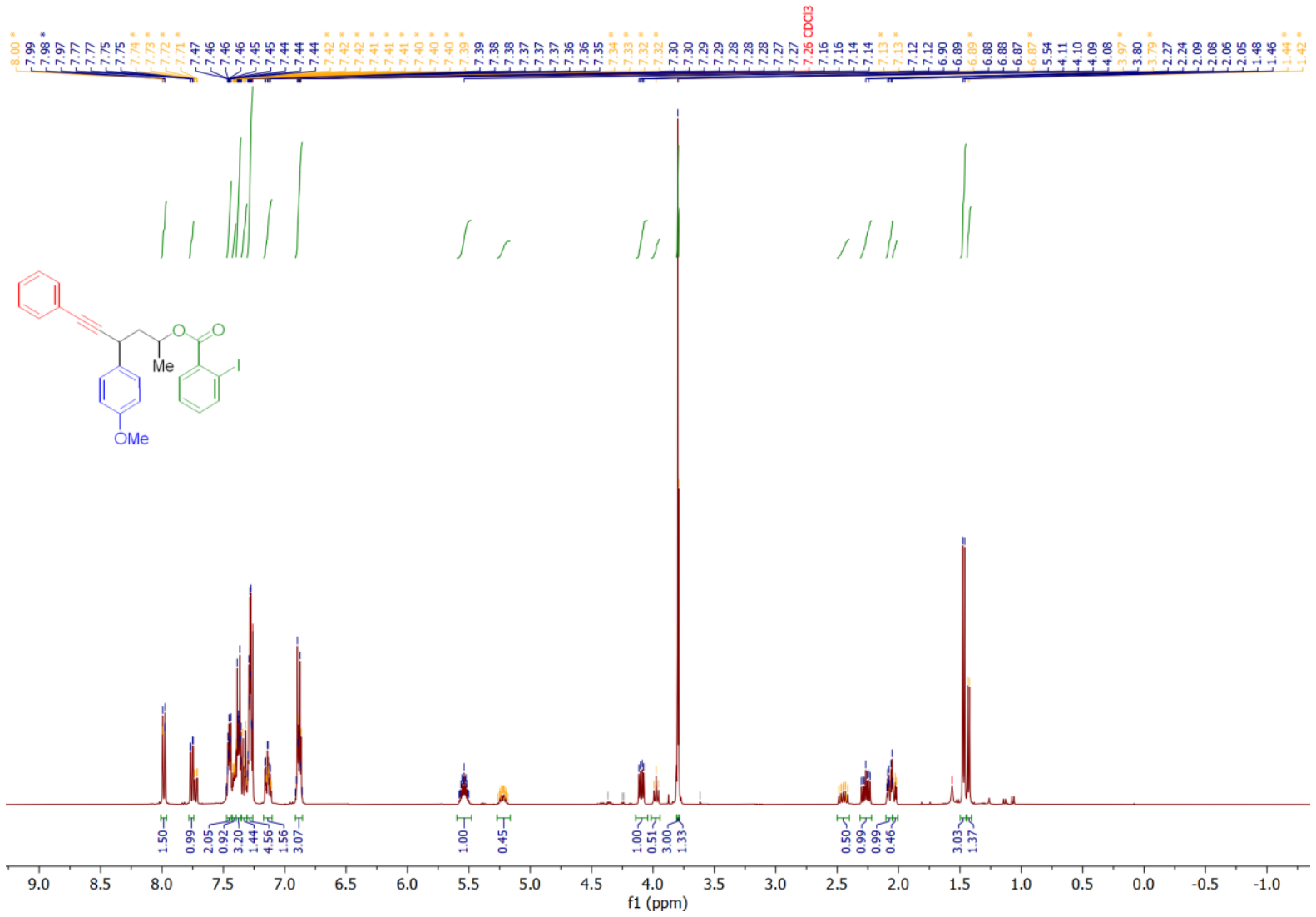

${ }^{13} \mathrm{C}$ NMR (101 MHz, CDCl 3 ) (3i)
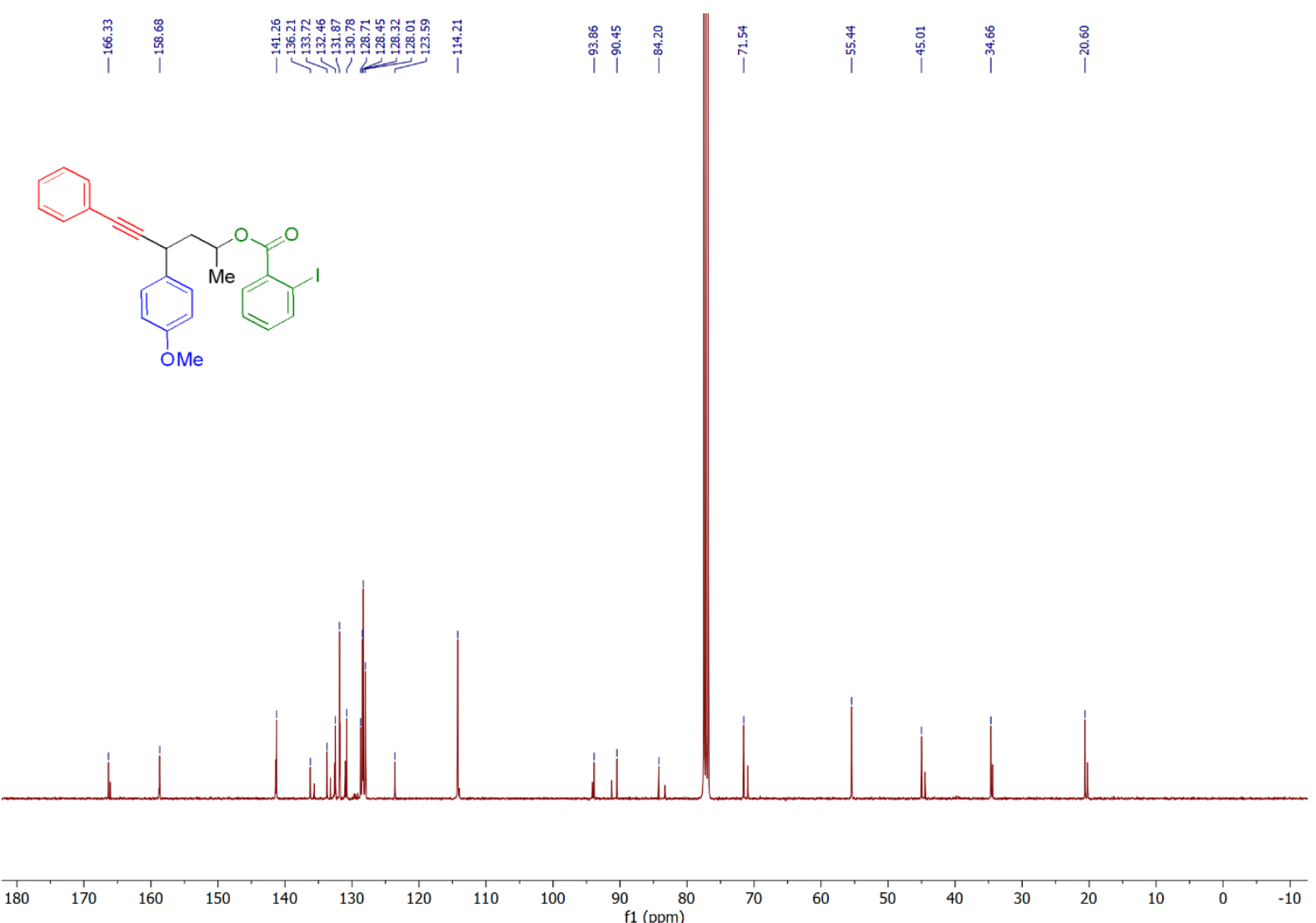
${ }^{1} \mathrm{H}$ NMR $\left(400 \mathrm{MHz}, \mathrm{CDCl}_{3}\right)(3 \mathrm{j})$

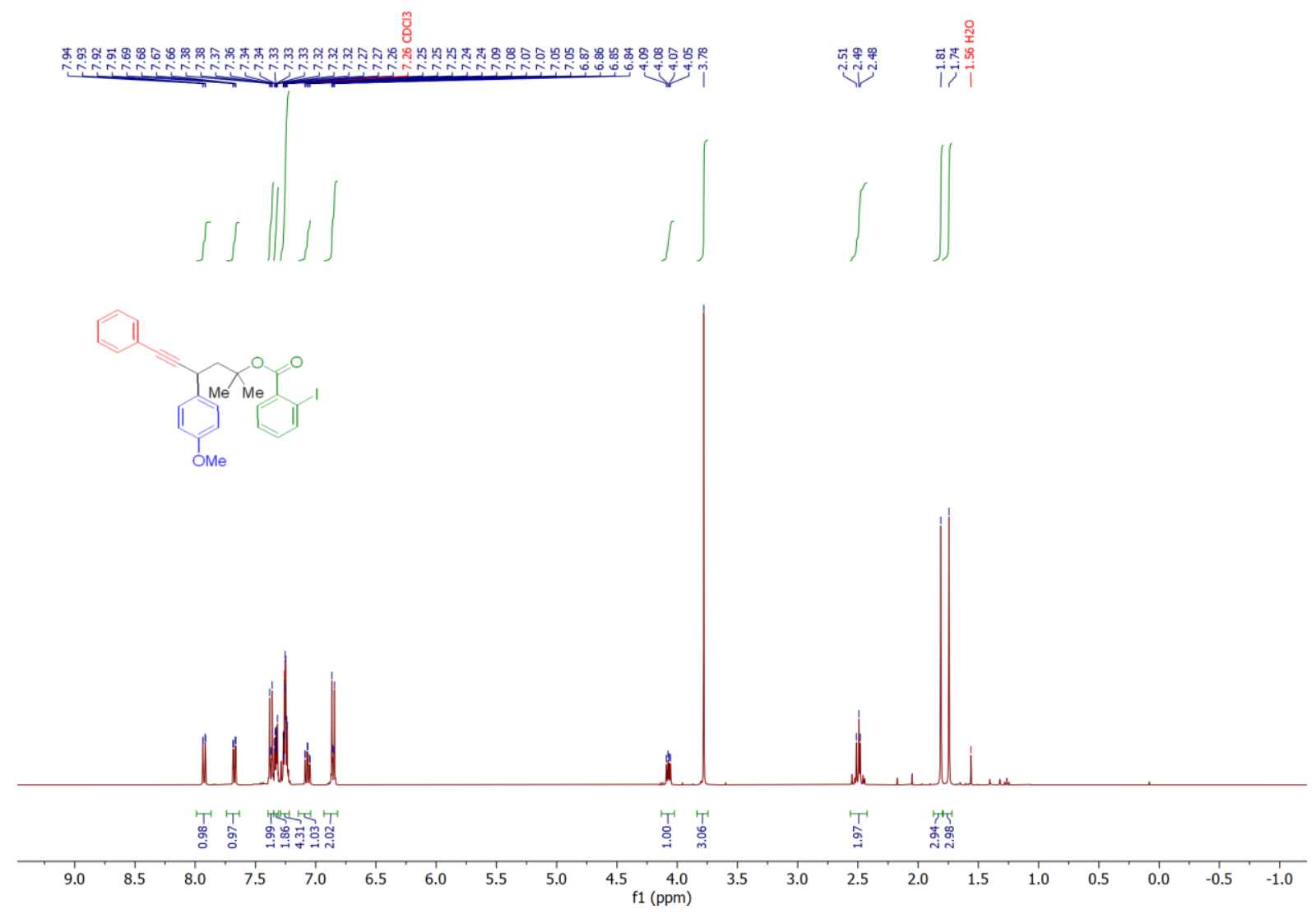

${ }^{13} \mathrm{C}$ NMR ${ }^{13} \mathrm{C}$ NMR (101 MHz, $\left.\mathrm{CDCl}_{3}\right)(\mathbf{3 j})$

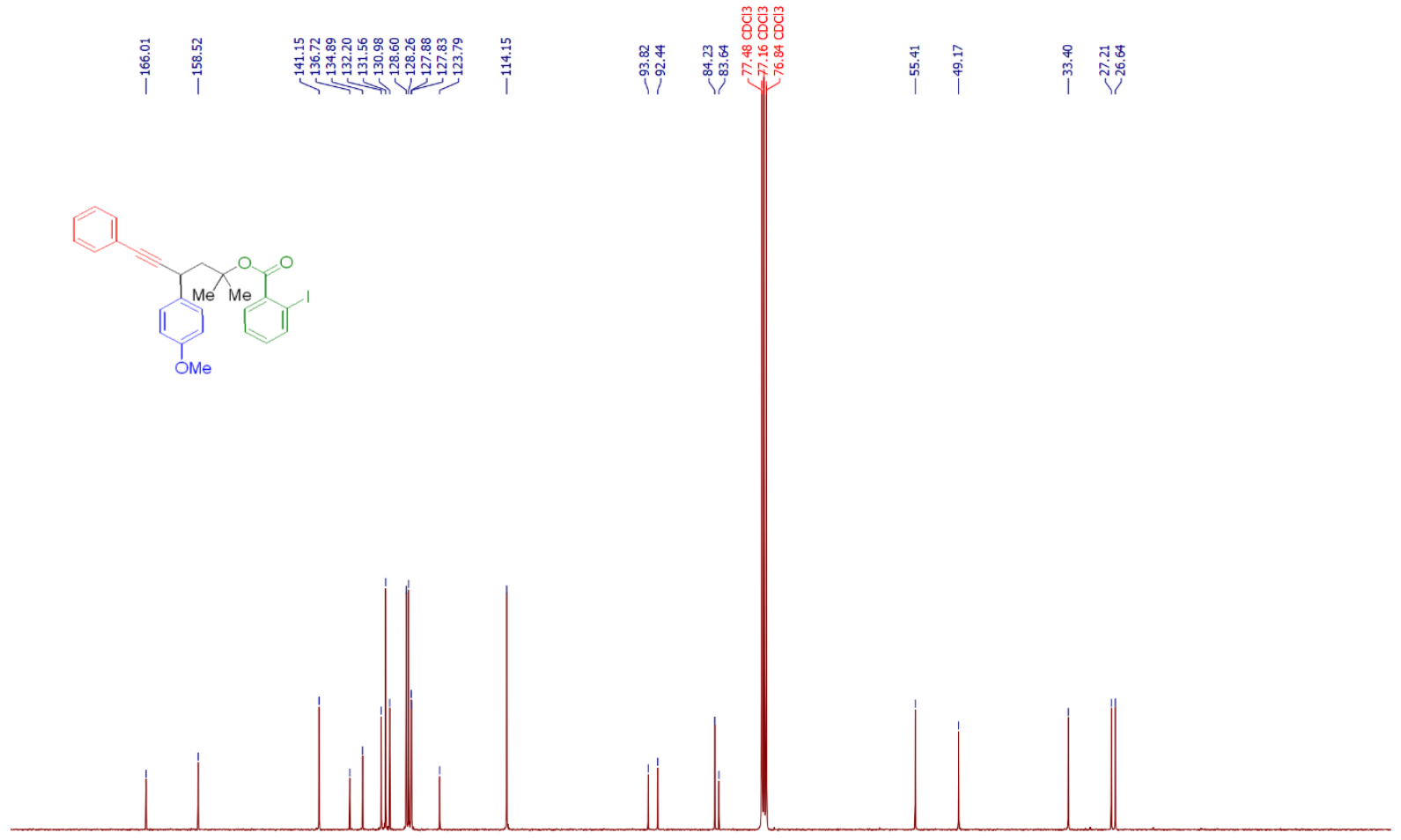

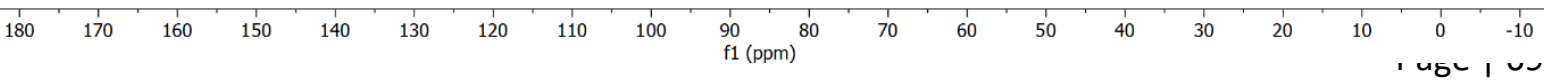


${ }^{1} \mathbf{H}$ NMR (400 MHz, $\left.\mathrm{CDCl}_{3}\right)$ (3k)

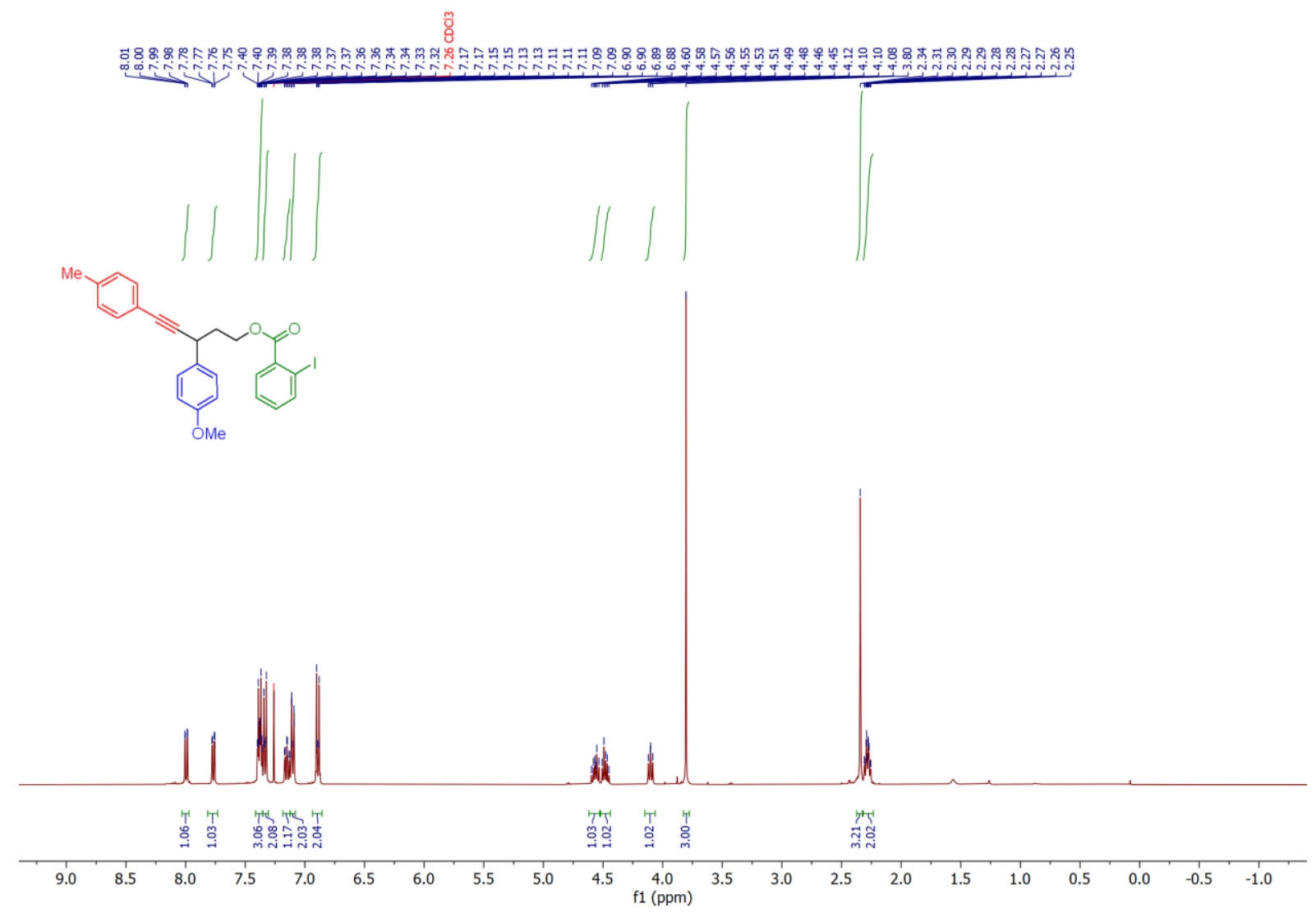

${ }^{13} \mathrm{C}$ NMR (101 MHz, $\left.\mathrm{CDCl}_{3}\right)$ (3k)
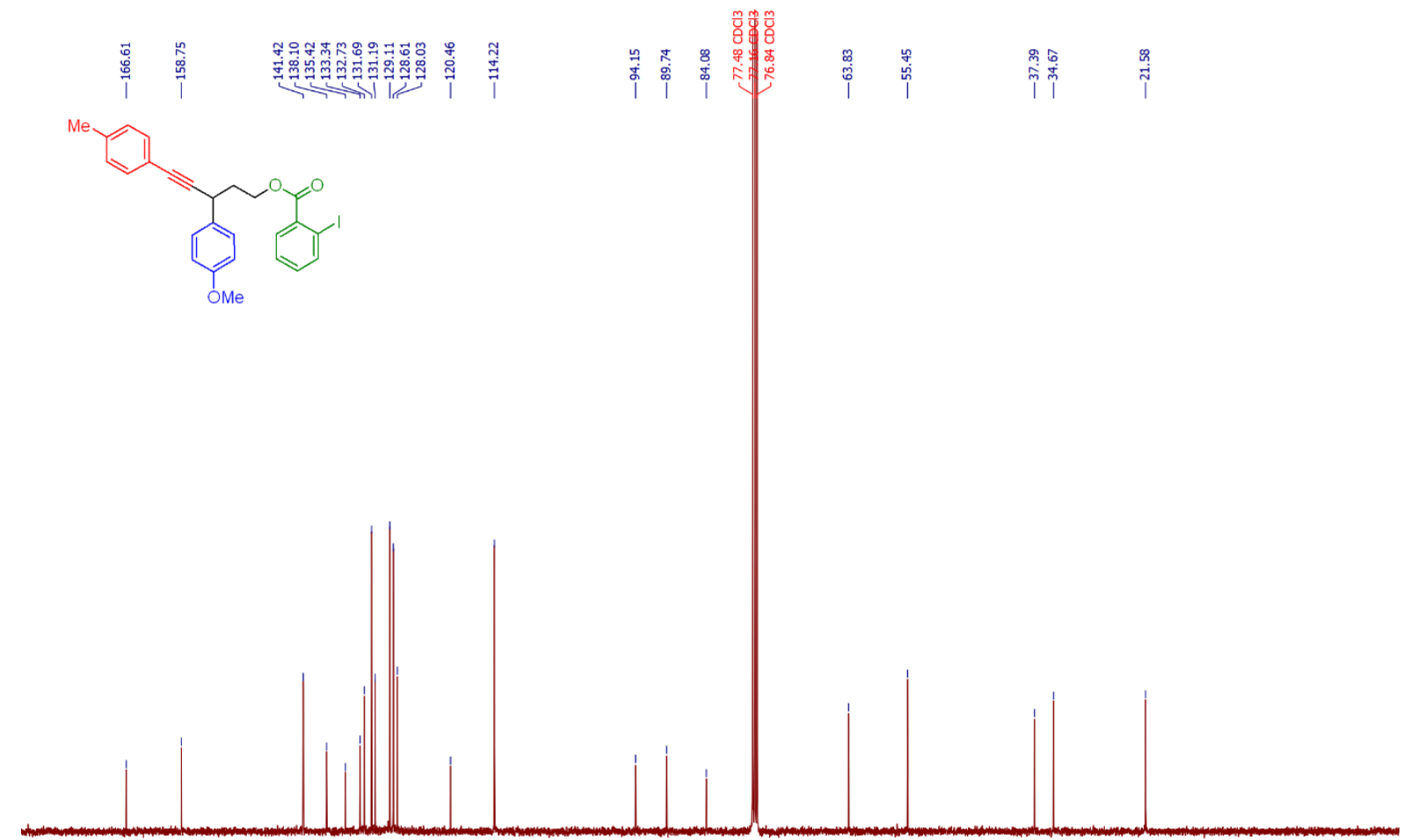

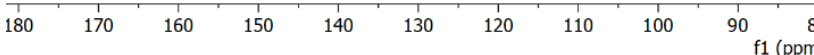


${ }^{1} \mathrm{H}$ NMR (400 MHz, $\left.\mathrm{CDCl}_{3}\right)(3 \mathrm{l})$

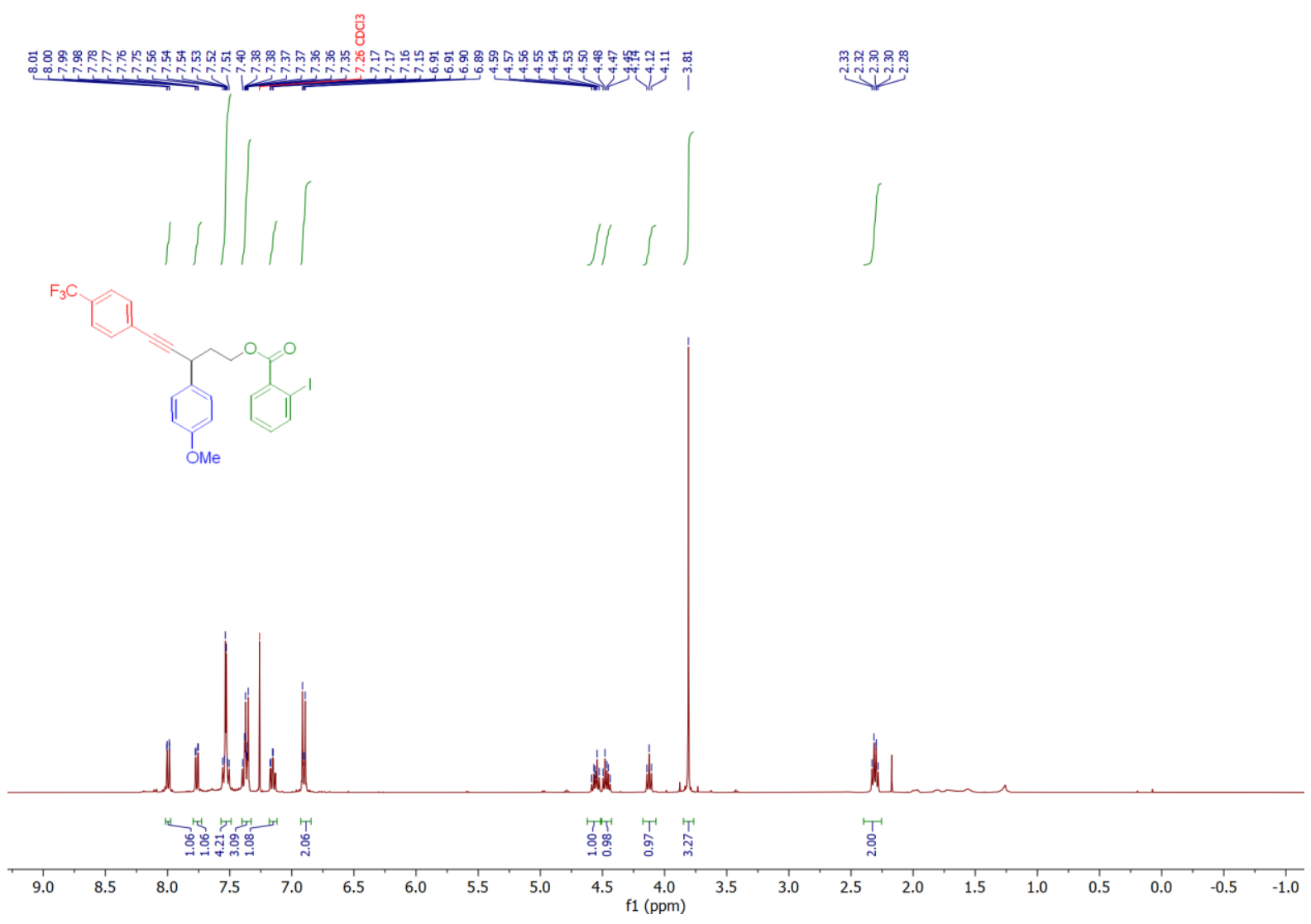

${ }^{13} \mathrm{C}$ NMR (101 MHz, $\left.\mathrm{CDCl}_{3}\right)$ (3I)

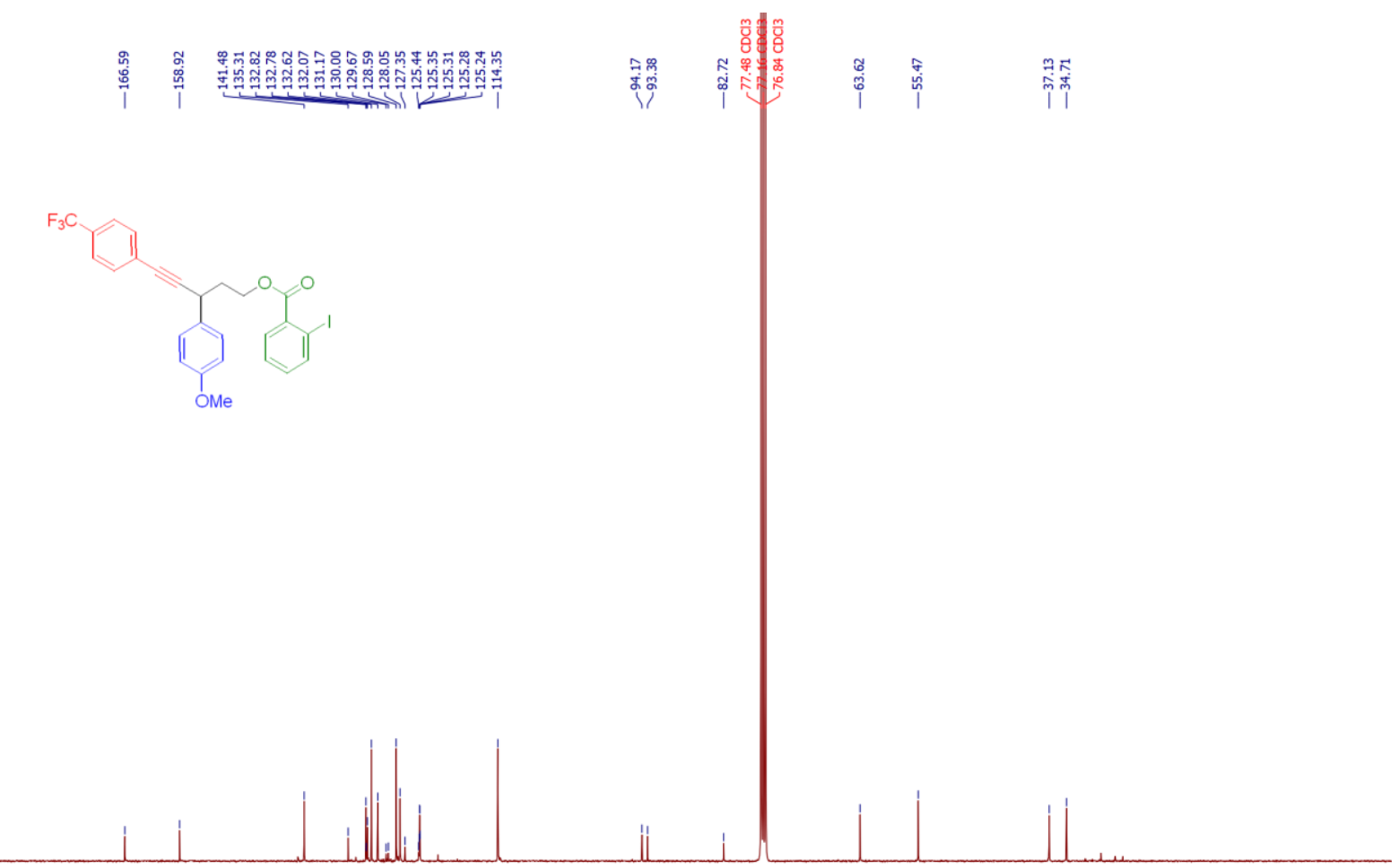

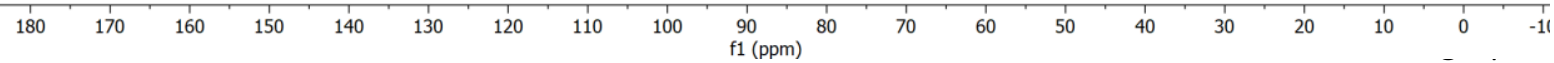


${ }^{19}$ F NMR (377 MHz, $\left.\mathrm{CDCl}_{3}\right)$ (3I)
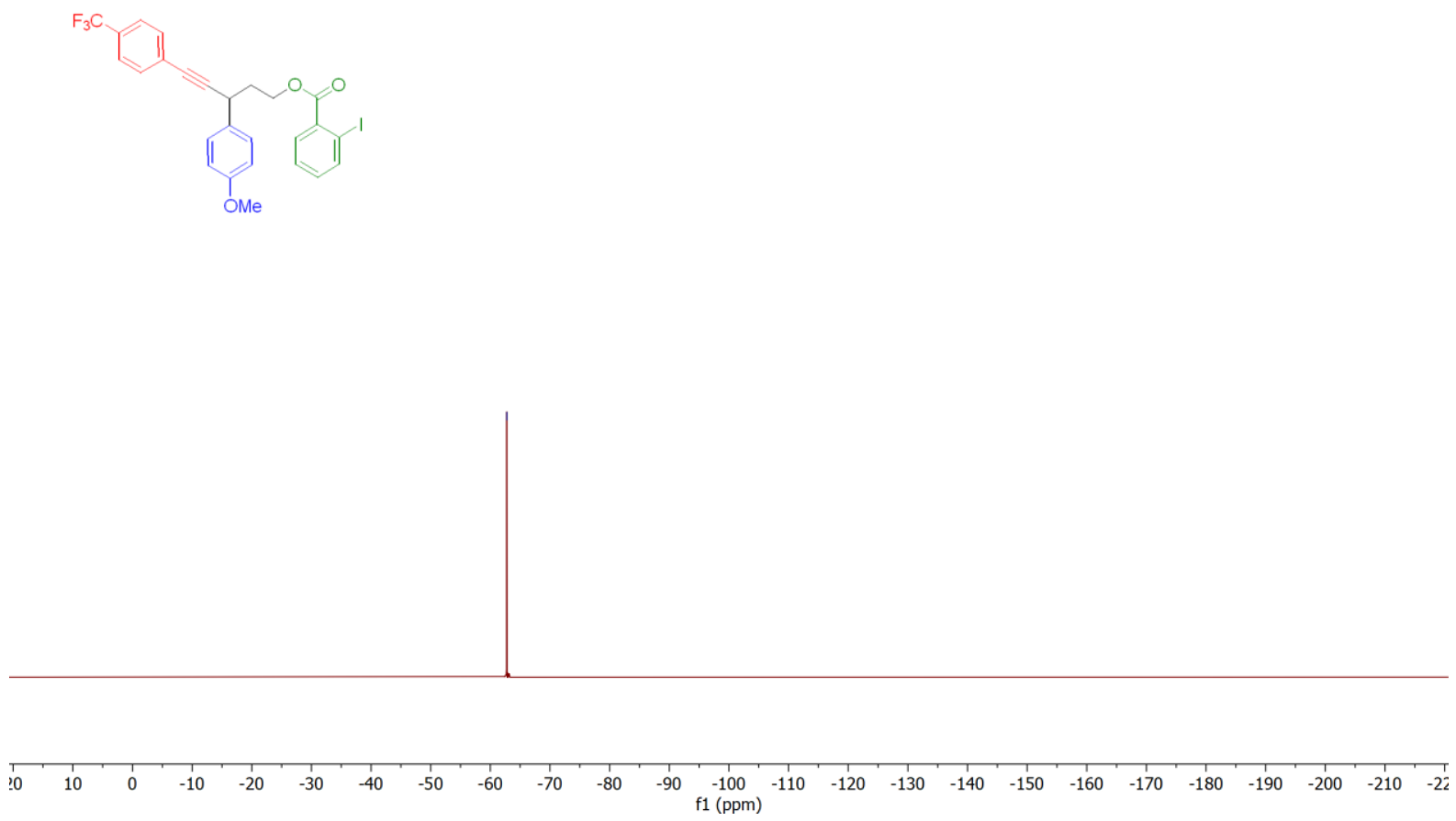
${ }^{1} \mathrm{H}$ NMR (400 MHz, $\left.\mathrm{CDCl}_{3}\right)(3 \mathrm{~m})$

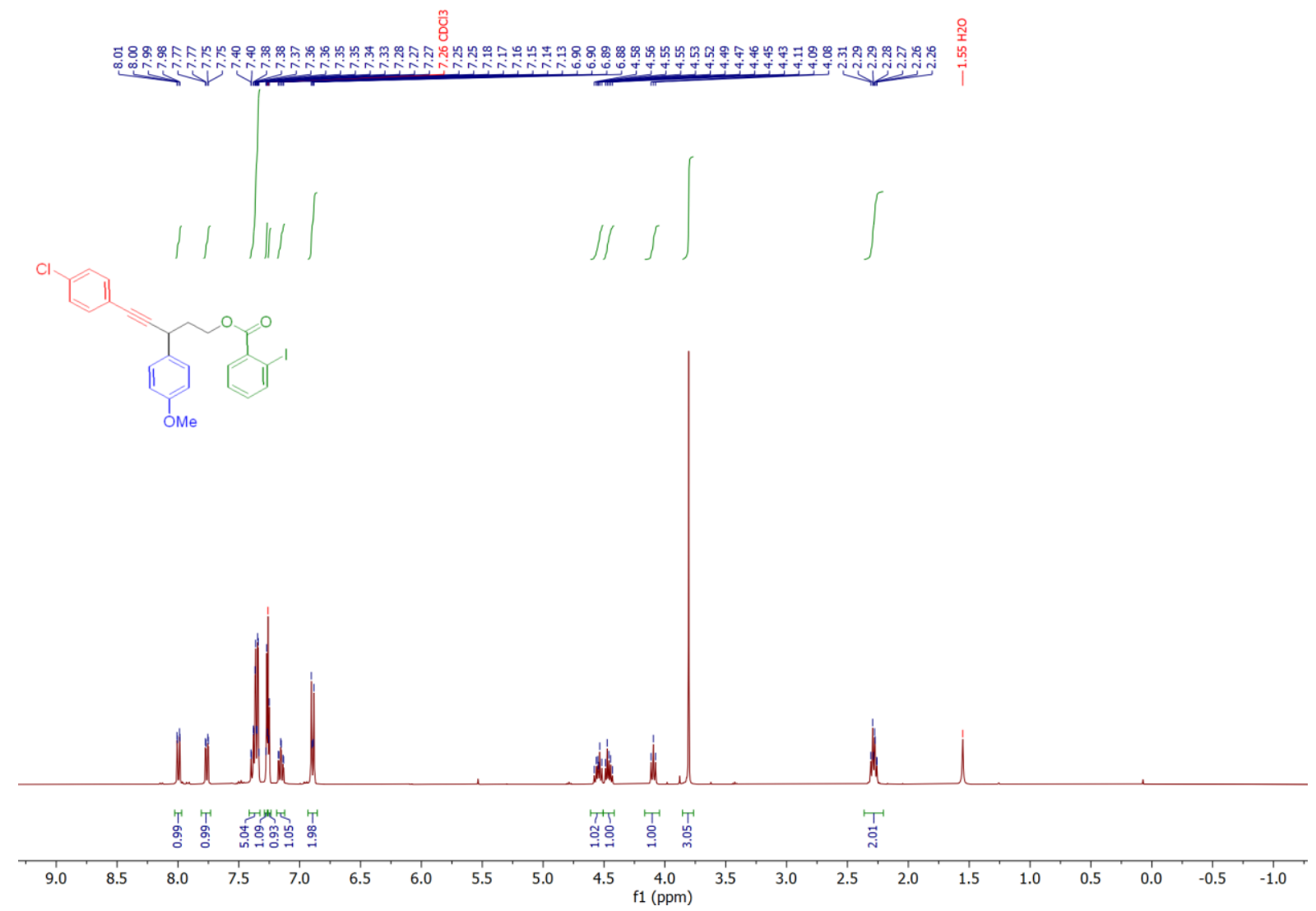

${ }^{13} \mathrm{C}$ NMR (101 MHz, $\left.\mathrm{CDCl}_{3}\right)(3 \mathrm{~m})$

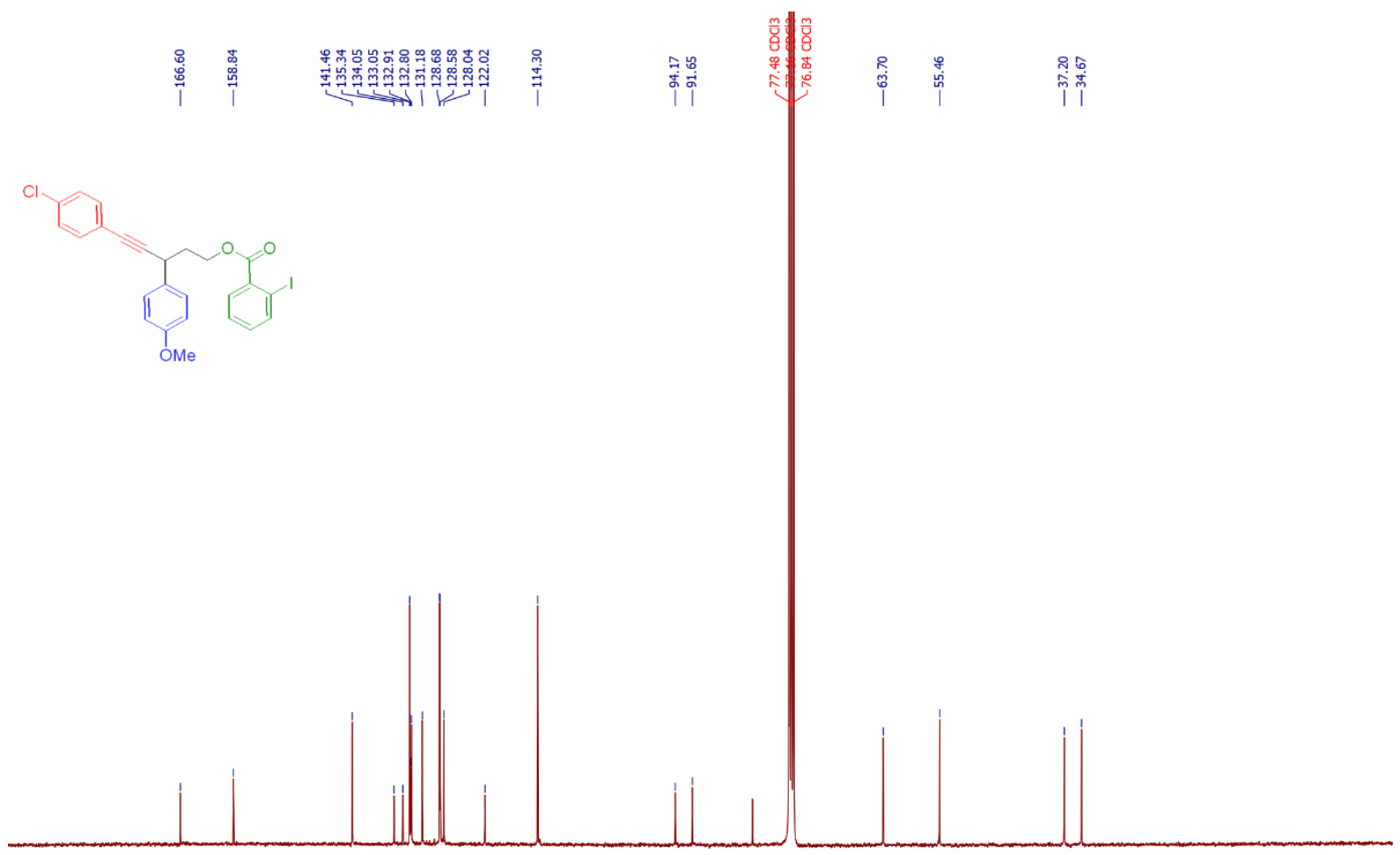

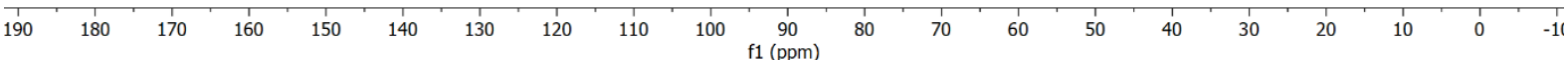


${ }^{1} \mathrm{H}$ NMR (400 MHz, $\left.\mathrm{CDCl}_{3}\right)(3 n)$

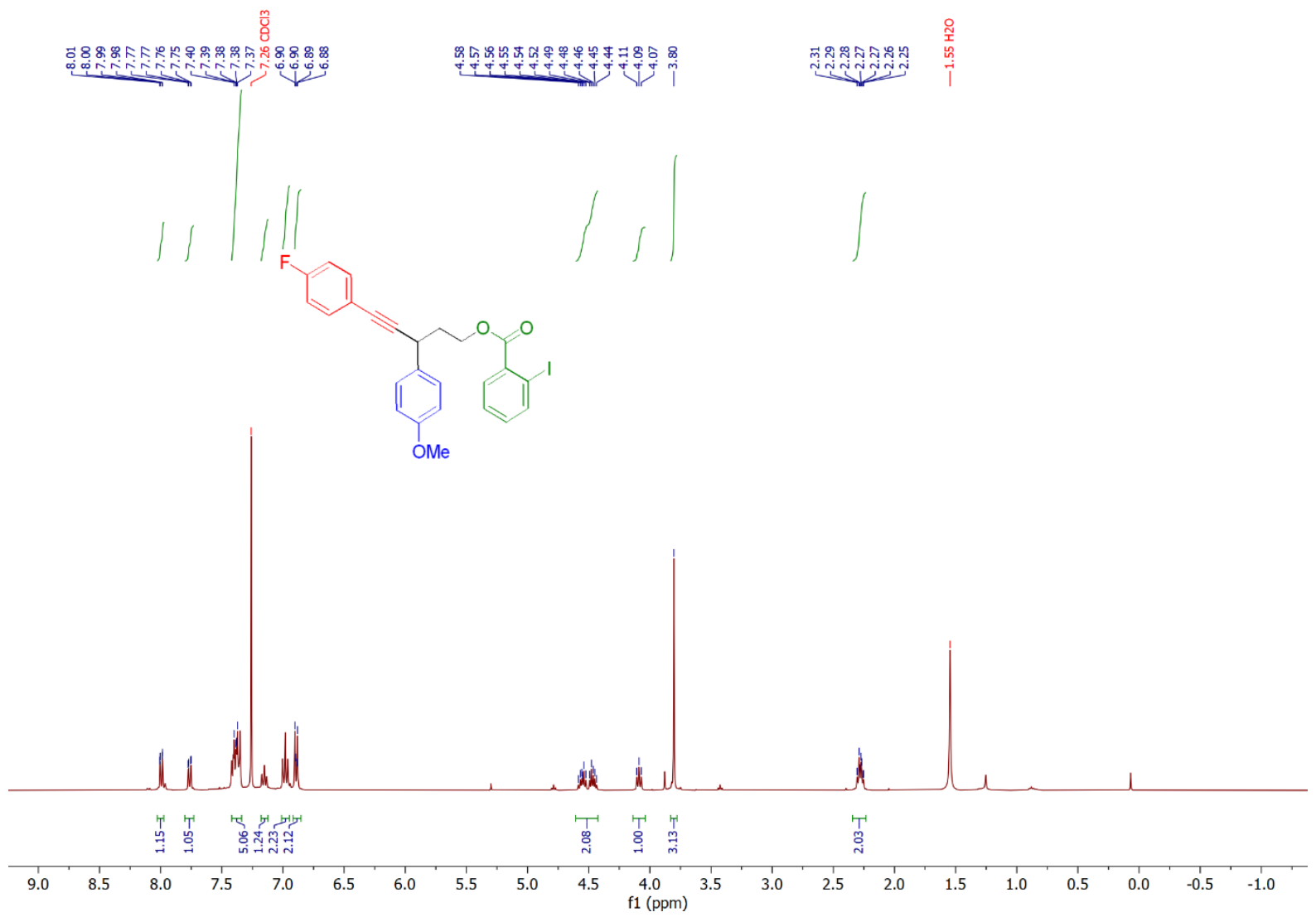

${ }^{13} \mathrm{C}$ NMR (201 MHz, $\left.\mathrm{CDCl}_{3}\right)(3 n)$

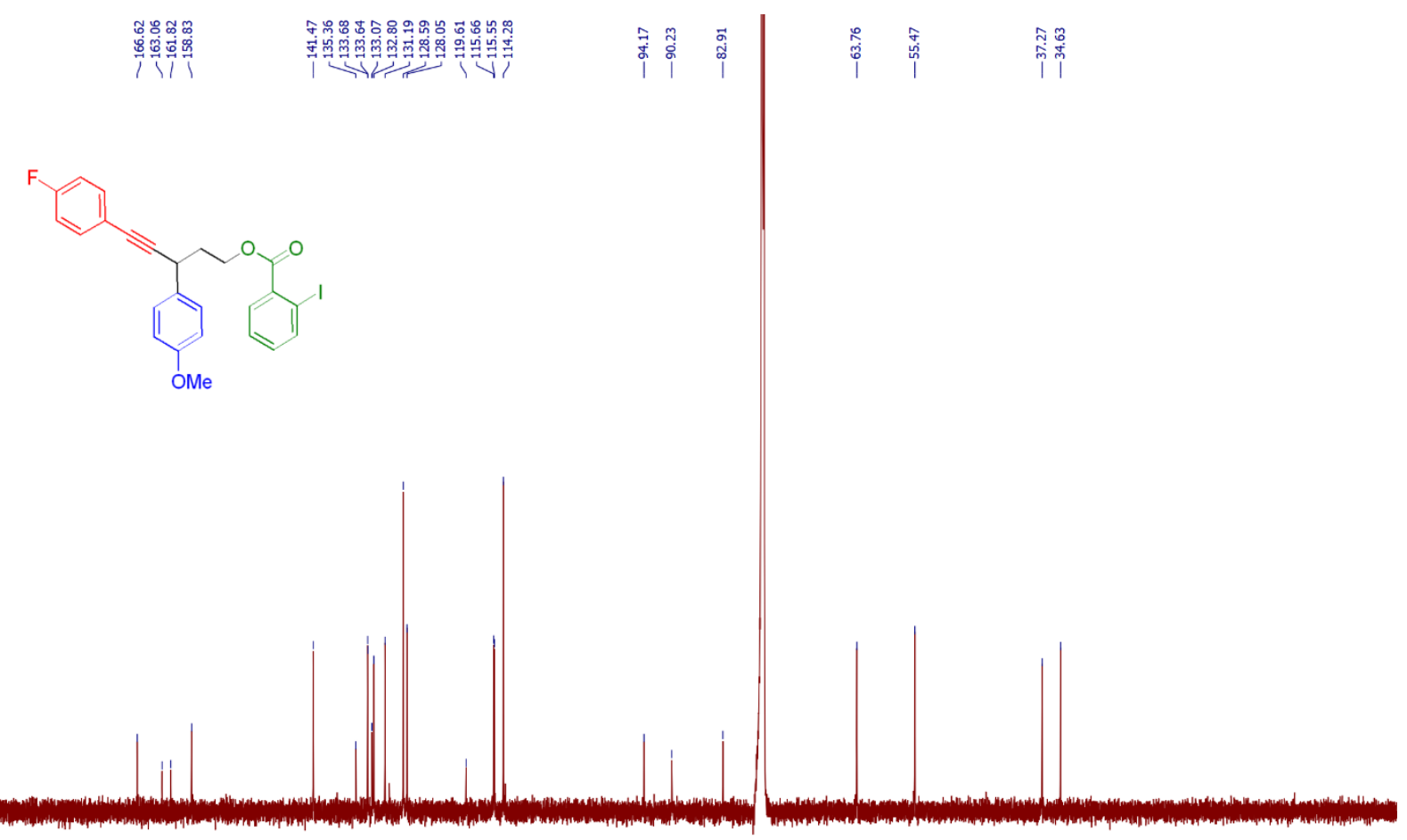

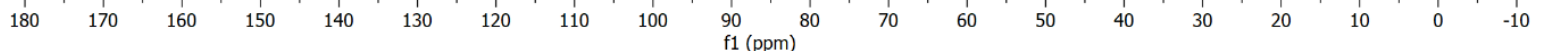


${ }^{19} \mathrm{~F}$ NMR (377 MHz, $\left.\mathrm{CDCl}_{3}\right)(3 \mathrm{n})$
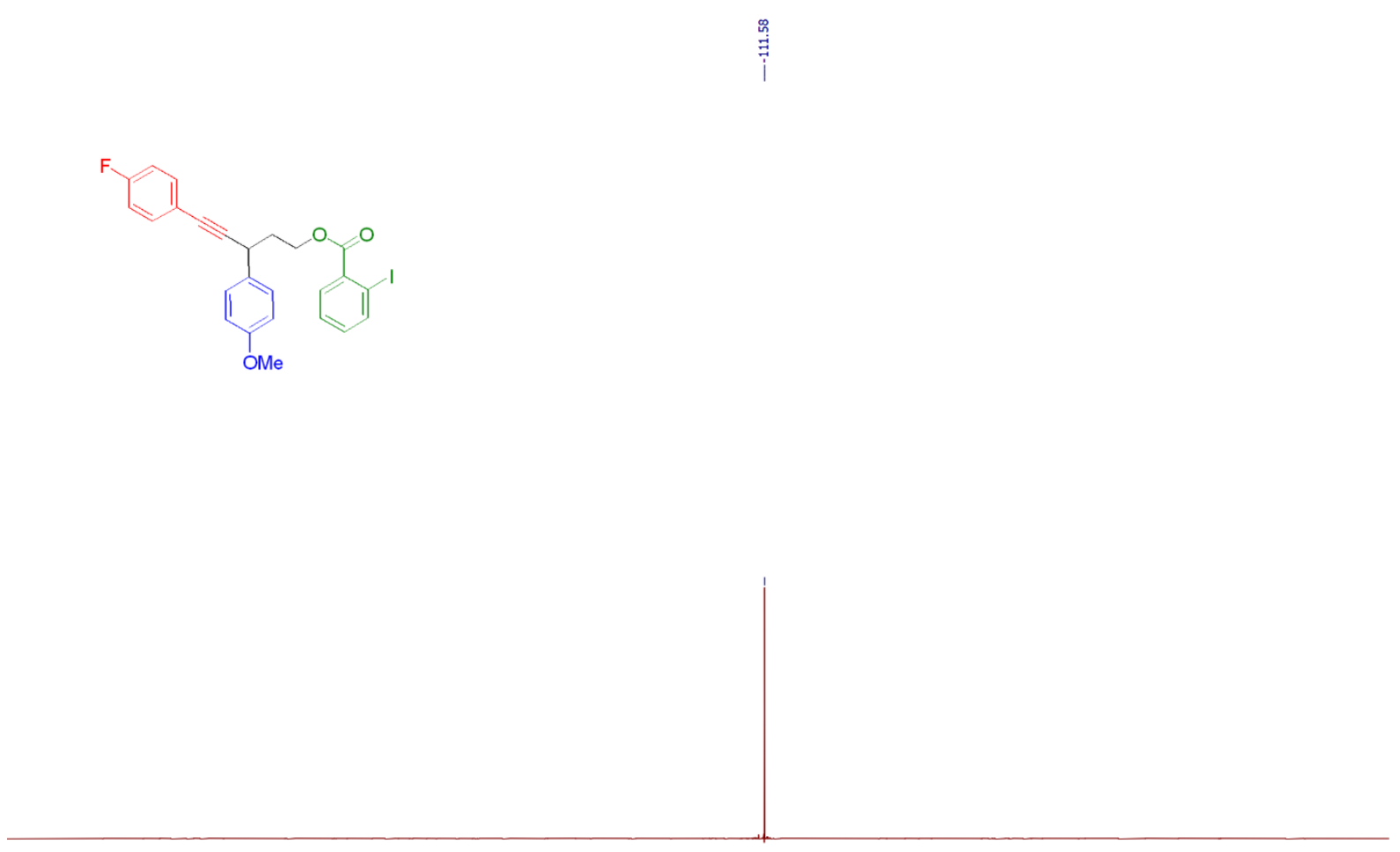

\begin{tabular}{llllllllllllllllllllllllllllllllll}
\hline 0 & 10 & 0 & -10 & -20 & -30 & -40 & -50 & -60 & -70 & -80 & -90 & -100 & -110 & -120 & -130 & -140 & -150 & -160 & -170 & -180 & -190 & -200 & -210 & -2.2
\end{tabular} 
${ }^{1} \mathrm{H}$ NMR (400 MHz, $\left.\mathrm{CDCl}_{3}\right)(30)$

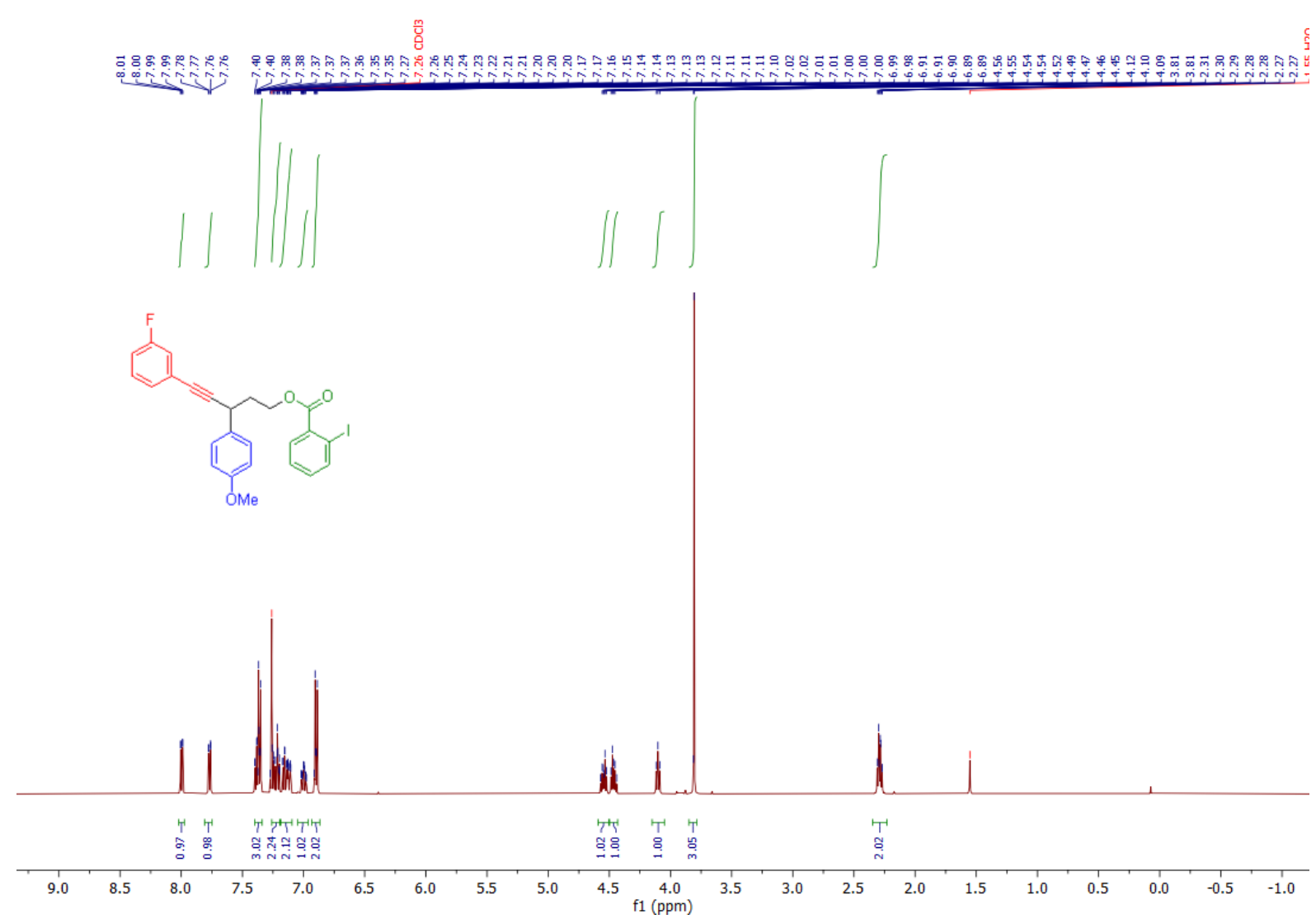

${ }^{13} \mathrm{C}$ NMR (101 MHz, $\mathrm{CDCl}_{3}$ ) (30)

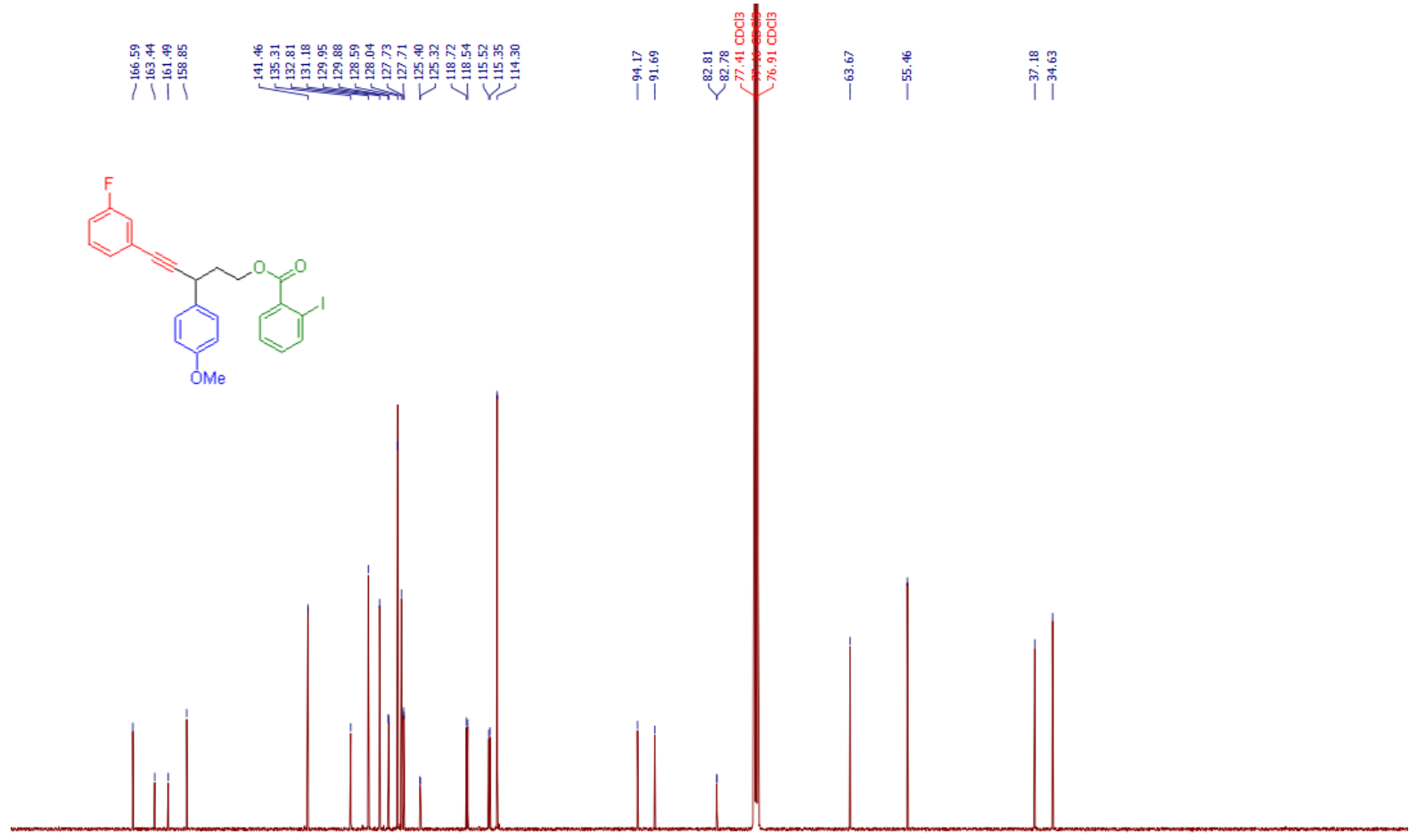

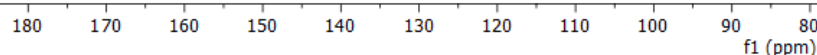


${ }^{19} \mathrm{~F}$ NMR (377 MHz, $\left.\mathrm{CDCl}_{3}\right)$ (3o)<smiles>O=C(OCCc1ccccc1)c1cccc(Cl)c1</smiles>

$$
\stackrel{\vec{\mu}}{\hat{i}}
$$

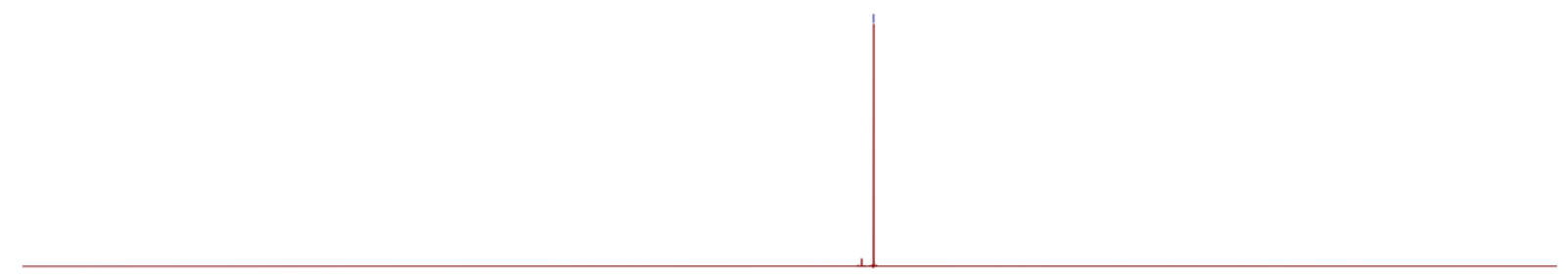

\begin{tabular}{llllllllllllllllllllllllllllllll}
10 & 10 & 0 & -10 & -20 & -30 & -40 & -50 & -60 & -70 & -80 & -90 & -100 & -110 & -120 & -130 & -140 & -150 & -160 & -170 & -180 & -190 & -200 & -210 & -24 \\
\hline
\end{tabular} 
${ }^{1} \mathrm{H}$ NMR (400 MHz, $\mathrm{CDCl}_{3}$ ) (3p)

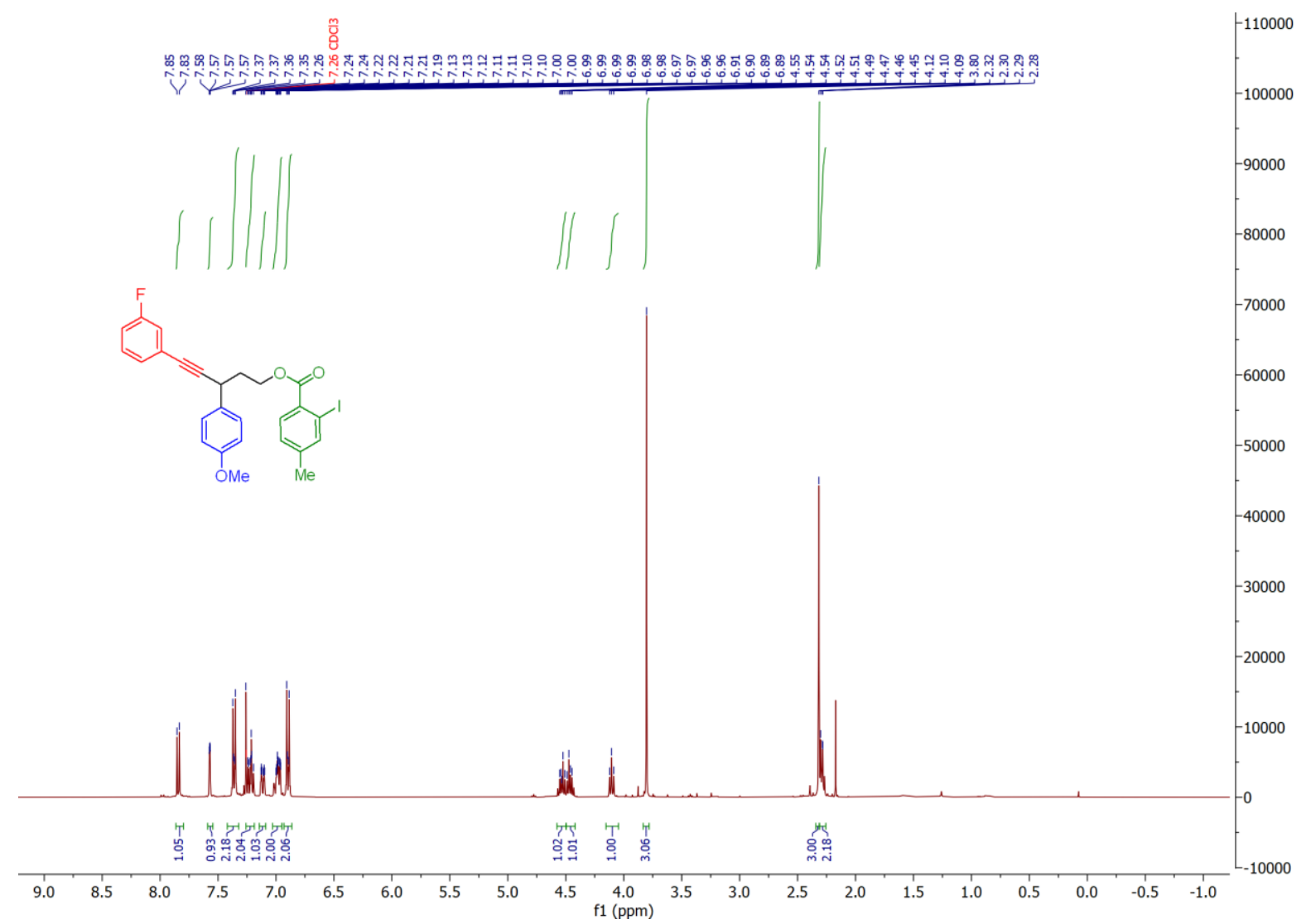

${ }^{13} \mathrm{C}$ NMR (101 $\left.\mathrm{MHz}, \mathrm{CDCl}_{3}\right)(3 p)$

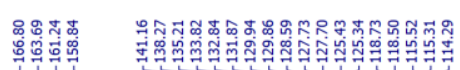

गर

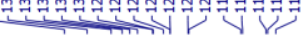
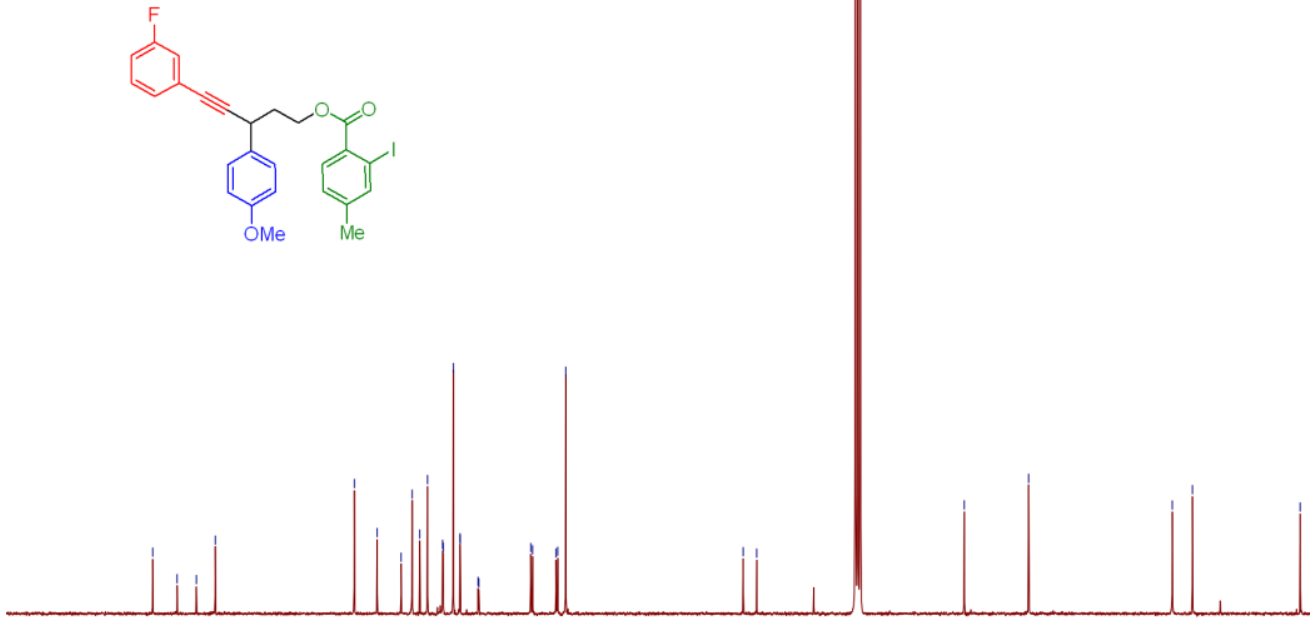

$\begin{array}{llllllllll}180 & 170 & 160 & 150 & 140 & 130 & 120 & 110 & 100 & 90 \\ \mathrm{f} 1(\mathrm{ppm})\end{array}$ 
${ }^{19} \mathrm{~F}$ NMR (377 MHz, $\left.\mathrm{CDCl}_{3}\right)(3 p)$

$$
\stackrel{\stackrel{9}{\sharp}}{\mathrm{i}}
$$

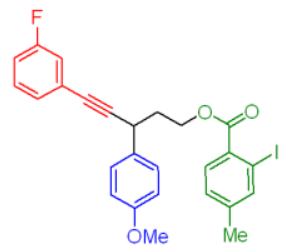

\begin{tabular}{llllllllllllllllllllllllllllllllll}
\hline 0 & 10 & 0 & -10 & -20 & -30 & -40 & -50 & -60 & -70 & -80 & -90 & -100 & -110 & -120 & -130 & -140 & -150 & -160 & -170 & -180 & -190 & -200 & -210 & -22 \\
\hline
\end{tabular} 
${ }^{1} \mathrm{H}$ NMR (400 MHz, $\mathrm{CDCl}_{3}$ ) (3q)

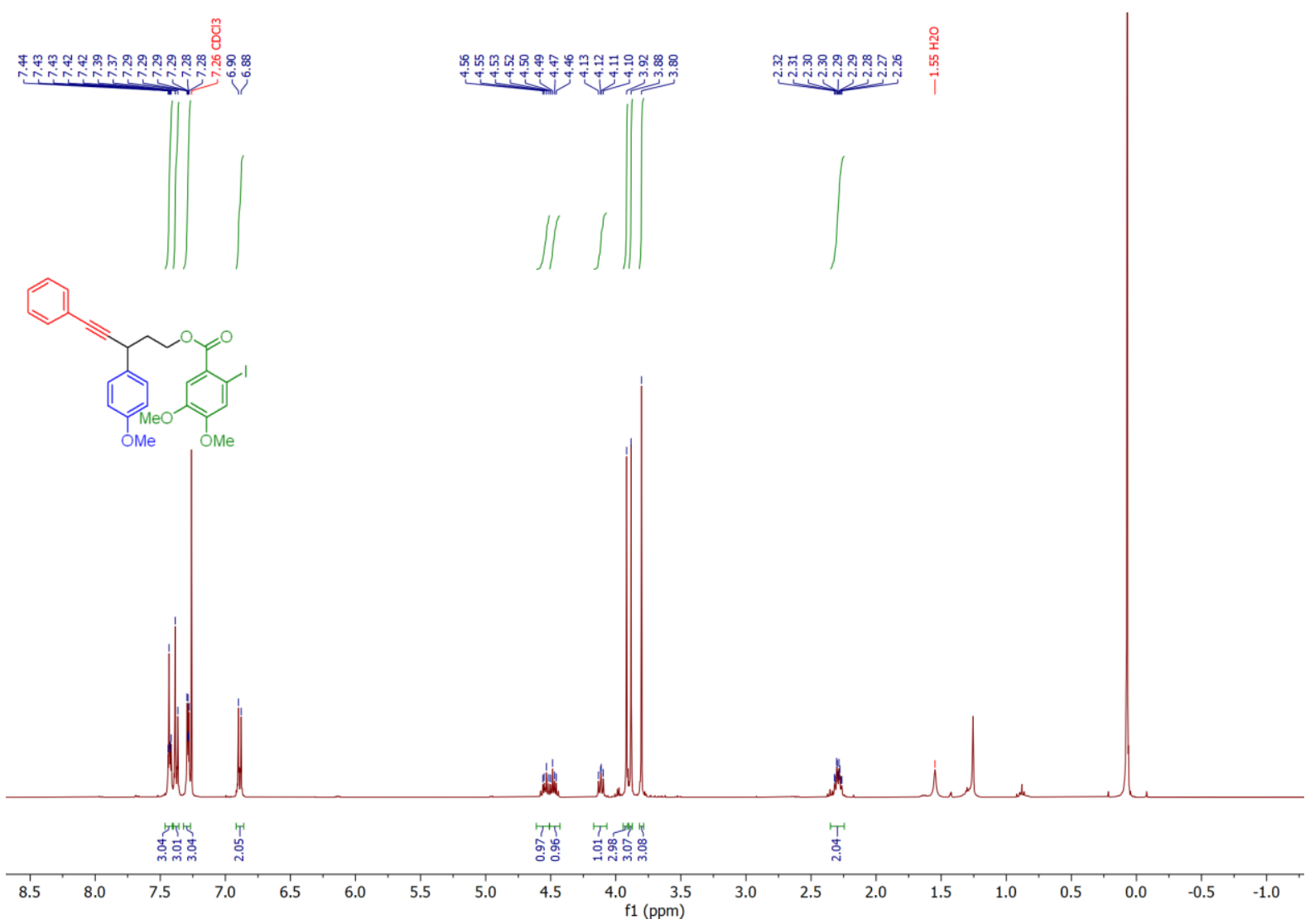

${ }^{13} \mathrm{C}$ NMR (201 $\left.\mathrm{MHz}, \mathrm{CDCl}_{3}\right)(3 q)$

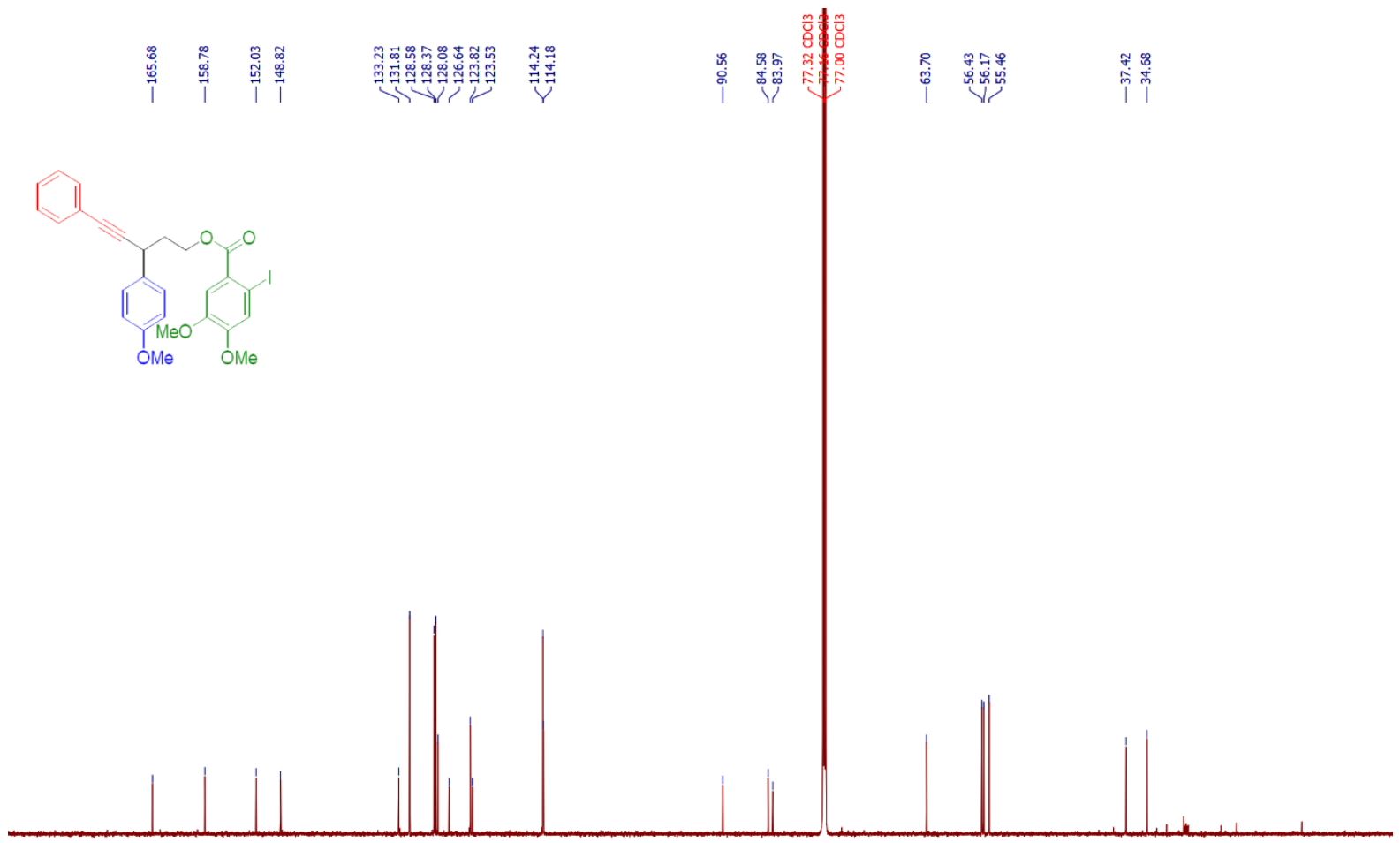

$\begin{array}{lllllllll}180 & 170 & 160 & 150 & 140 & 130 & 120 & 110 & 100 \begin{array}{r}90 \\ \mathrm{f} 1(\mathrm{ppm})\end{array}\end{array}$

Page | 80 
Blue: Major diastereomer, *Orange : Minor diastereomer

${ }^{1} \mathrm{H}$ NMR $\left(400 \mathrm{MHz}, \mathrm{CDCl}_{3}(8 \mathrm{a})\right.$

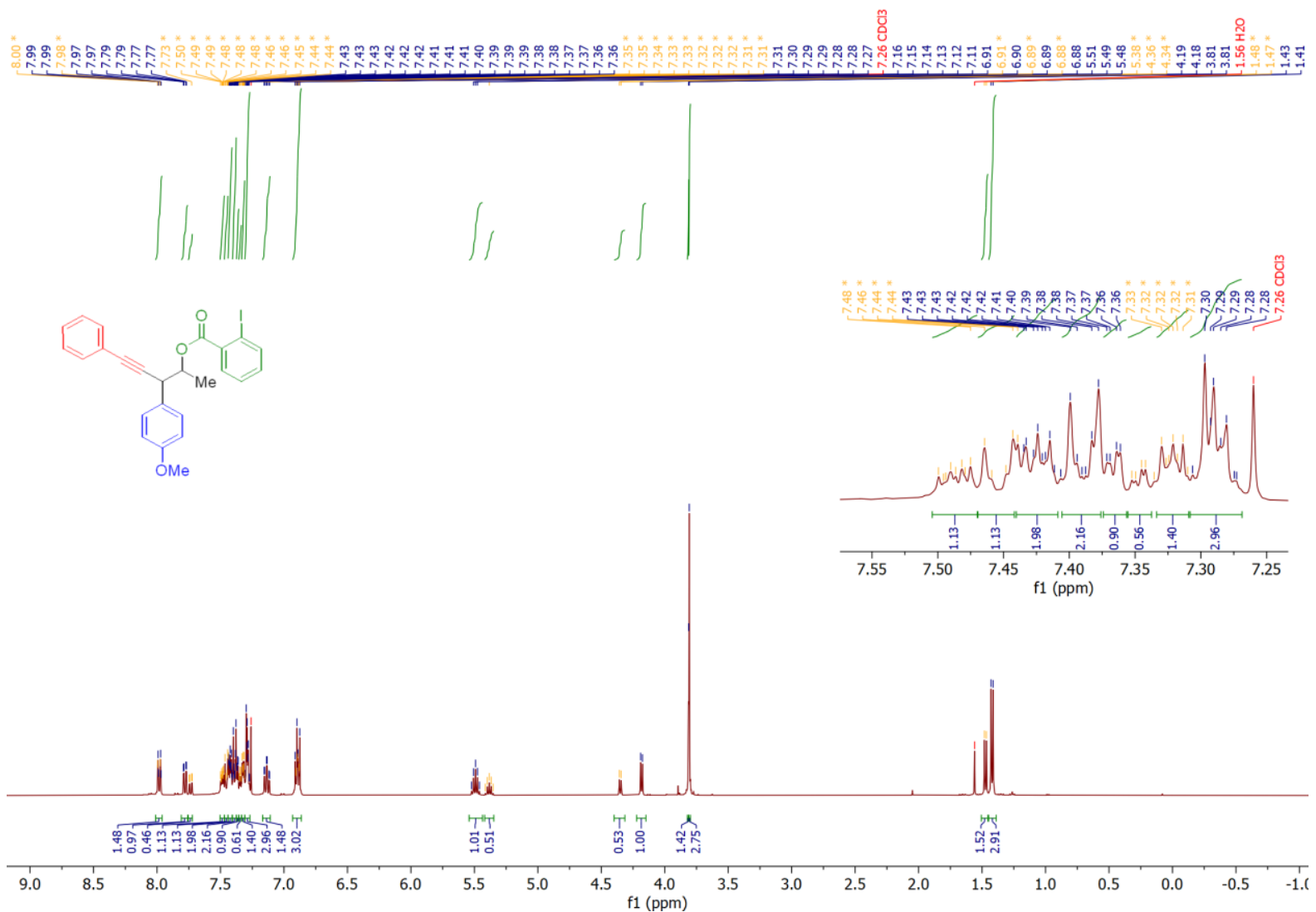

${ }^{13} \mathrm{C}$ NMR (101 $\mathrm{MHz} \mathrm{CDCl}_{3}$ (8a)

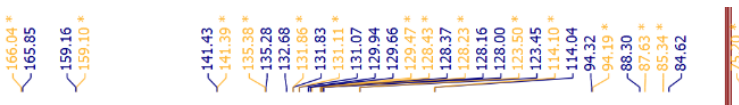
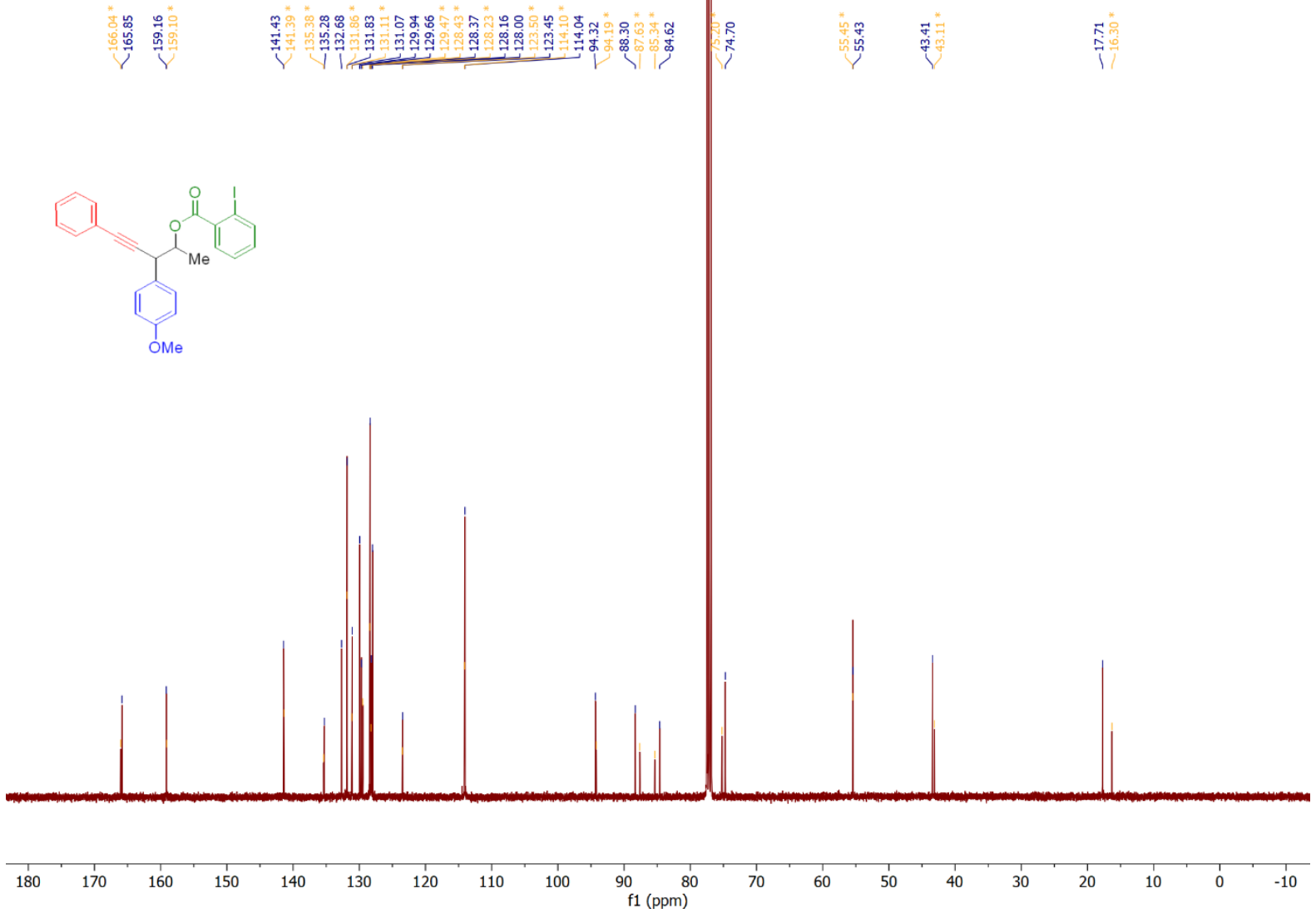
${ }^{1} \mathrm{H}$ NMR (400 MHz, $\left.\mathrm{CDCl}_{3}\right)(8 \mathrm{~b})$

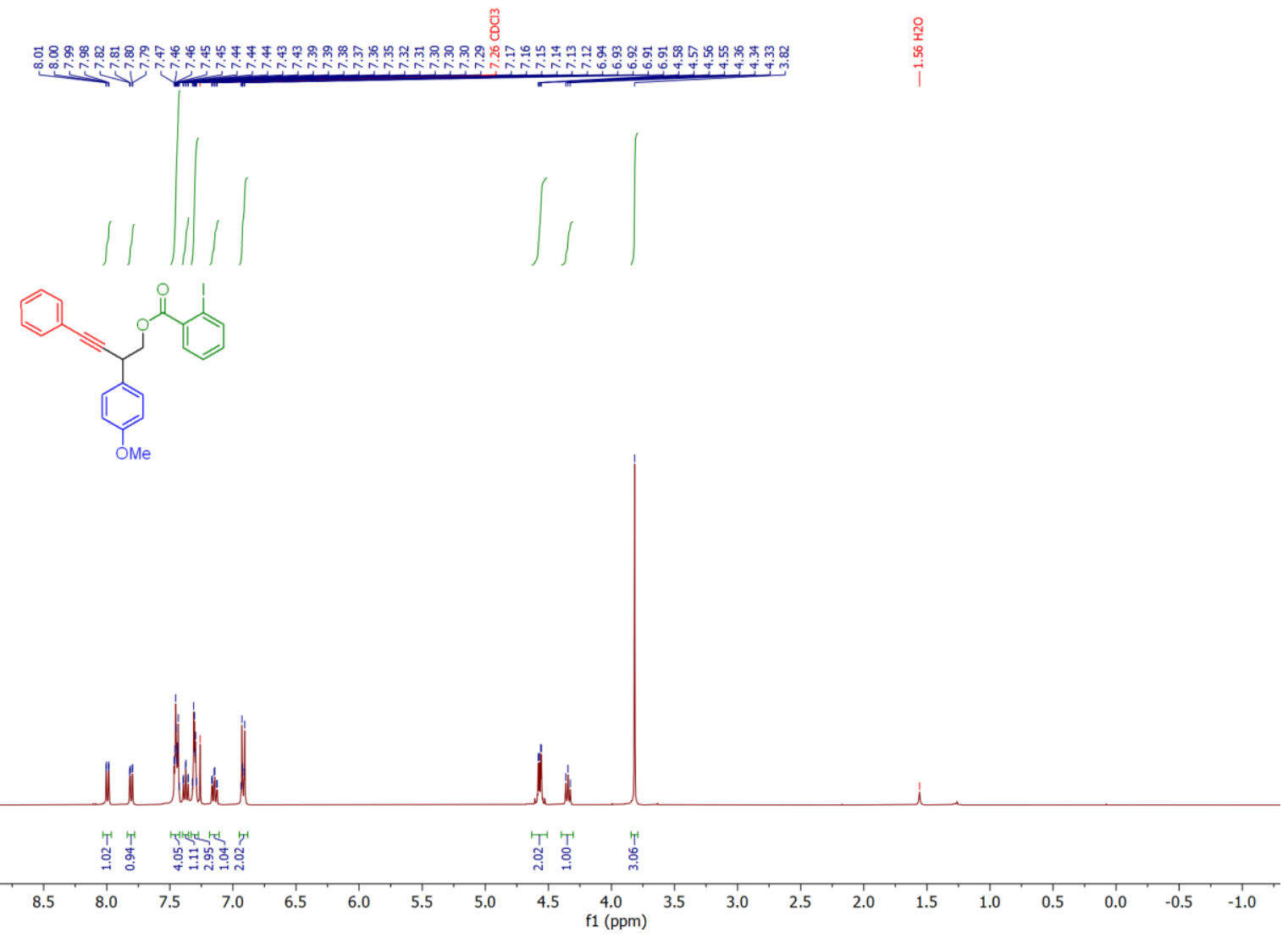

${ }^{13} \mathrm{C}$ NMR (101 MHz, $\mathrm{CDCl}_{3}$ ) (8b)
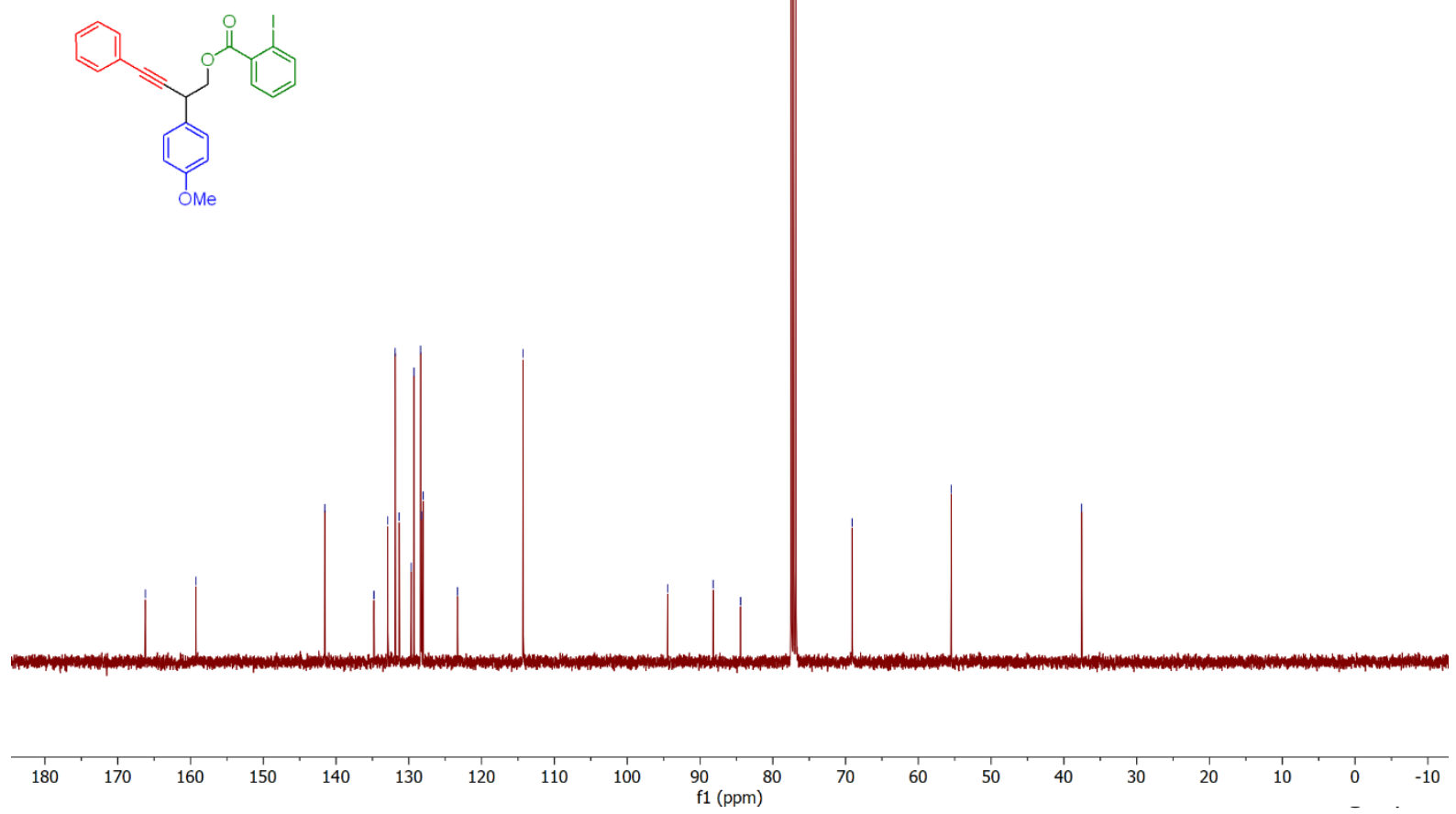
${ }^{1} \mathrm{H}$ NMR (400 MHz, $\mathrm{CDCl}_{3}(8 \mathrm{c})$

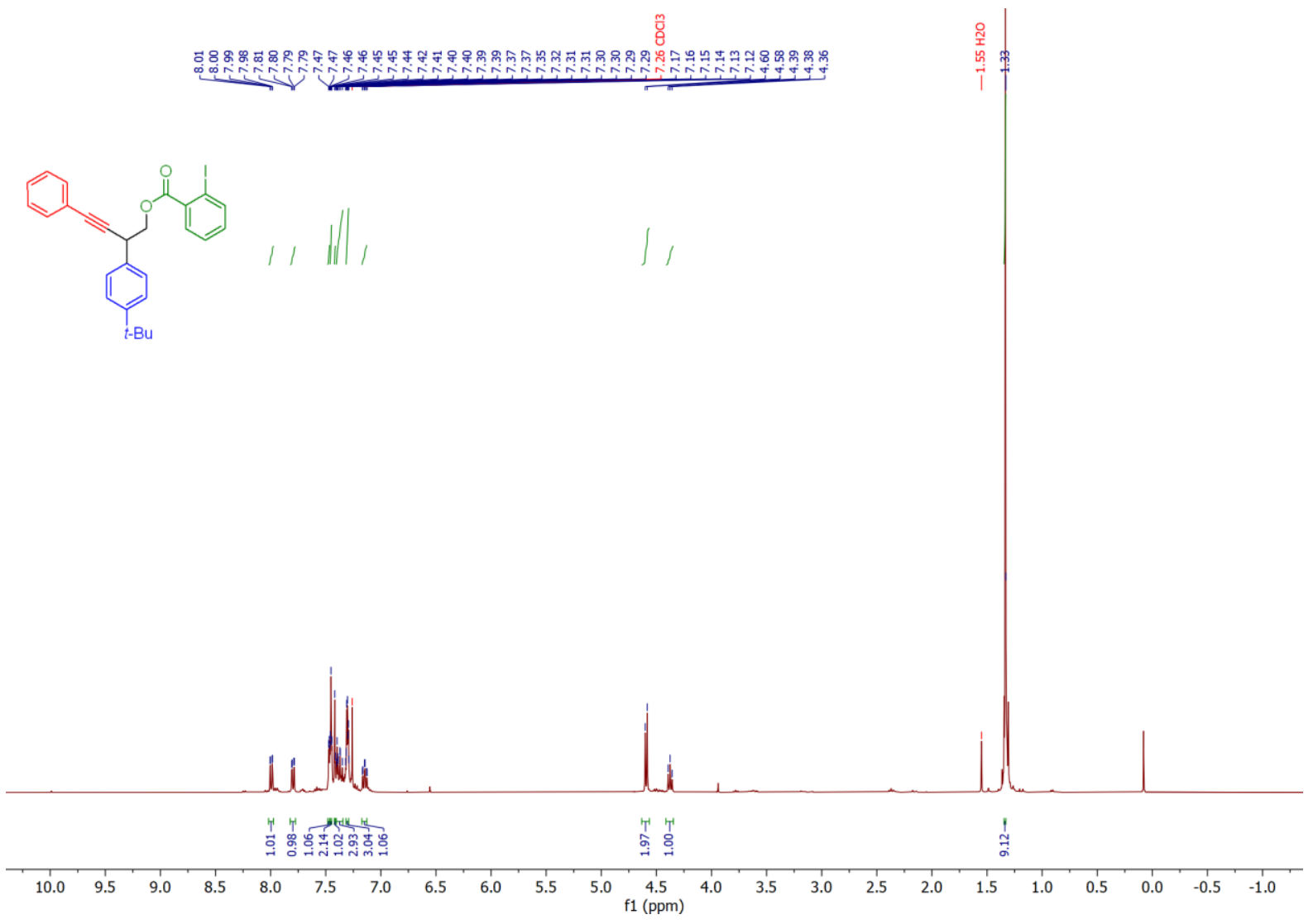

${ }^{13} \mathrm{C}$ NMR (101 MHz, $\left.\mathrm{CDCl}_{3}\right)(8 \mathrm{c})$

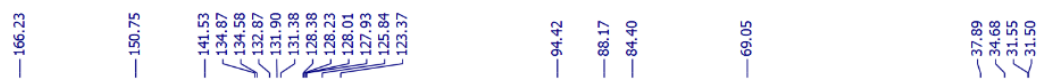

$\underbrace{2}_{t=\text { Bu }}$

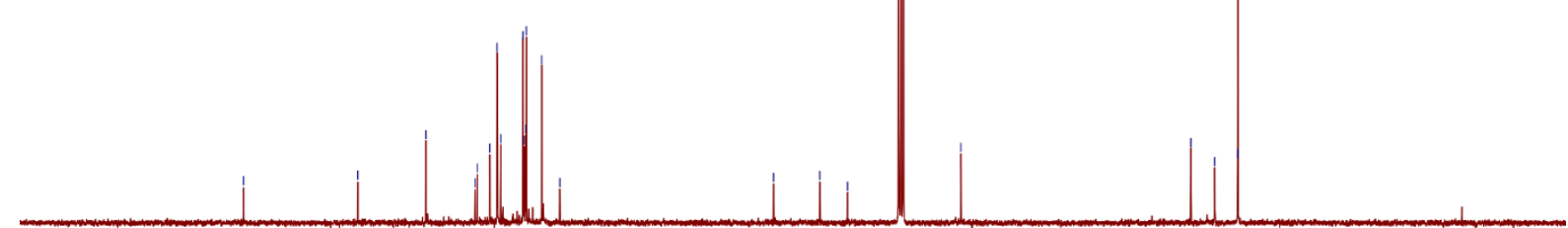

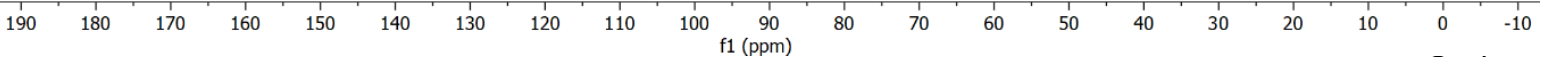


${ }^{1} \mathrm{H}$ NMR (400 MHz, $\mathrm{CDCl}_{3}$ ) (4a)

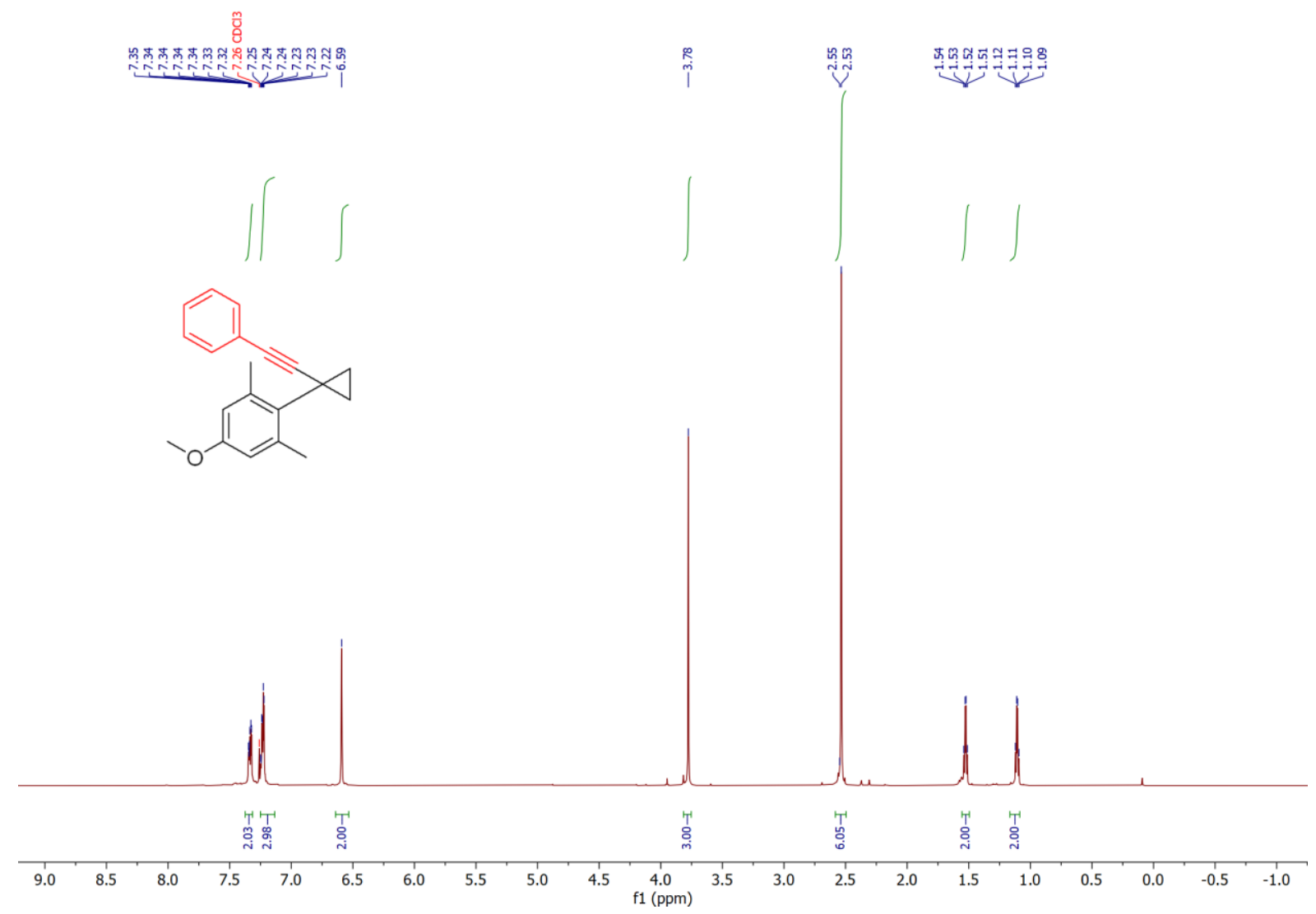

${ }^{13} \mathrm{C}$ NMR (101 $\left.\mathrm{MHz}, \mathrm{CDCl}_{3}\right)(4 \mathrm{a})$

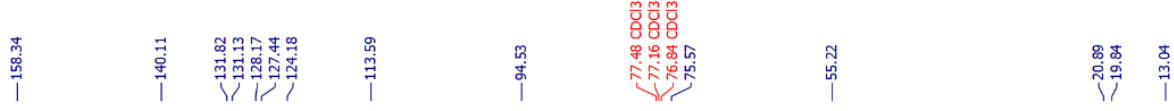

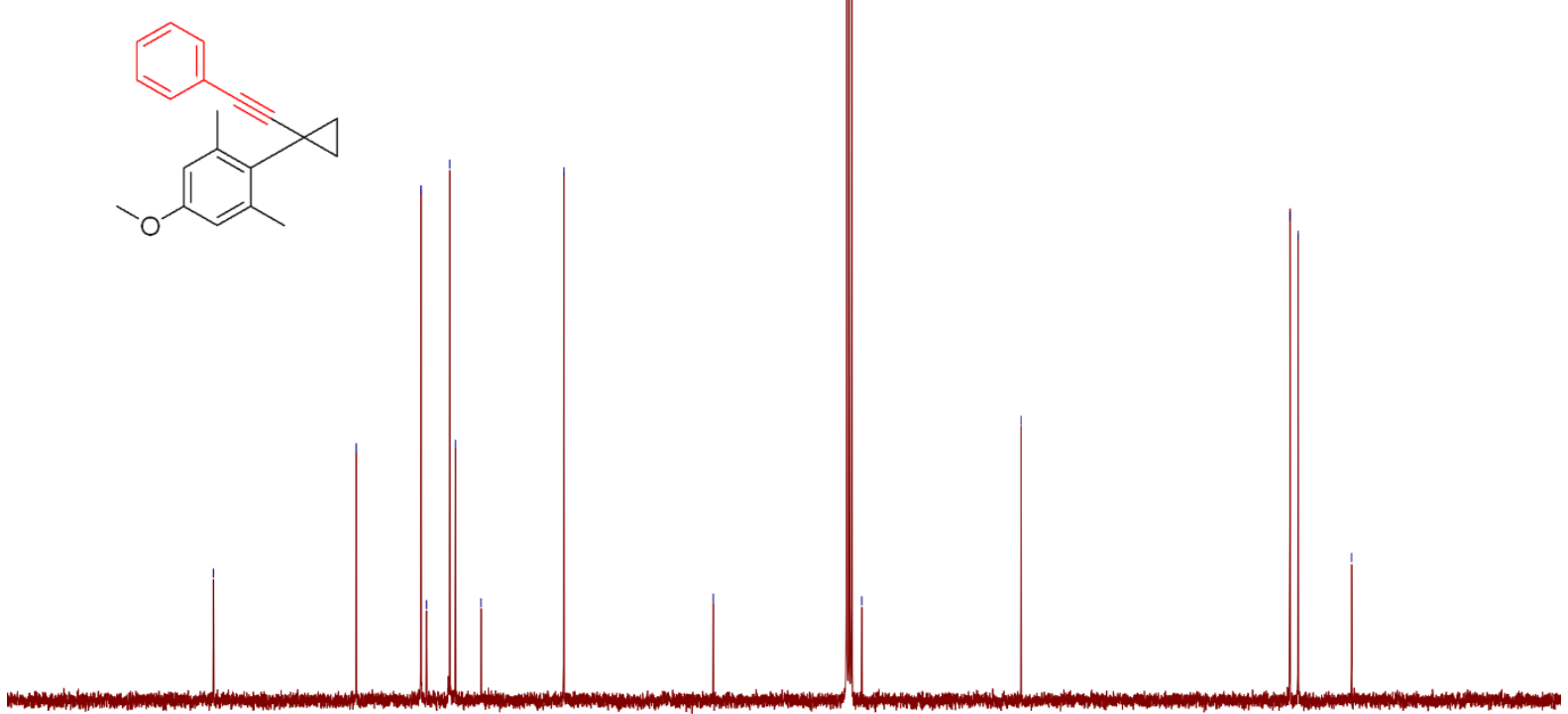

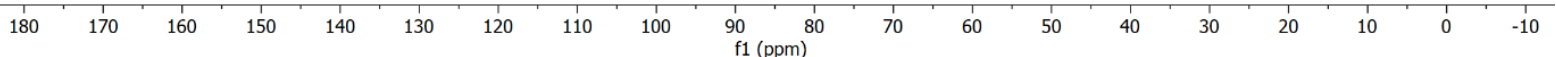


${ }^{1} \mathrm{H}$ NMR (400 MHz, $\mathrm{CDCl}_{3}$ ) (4b)

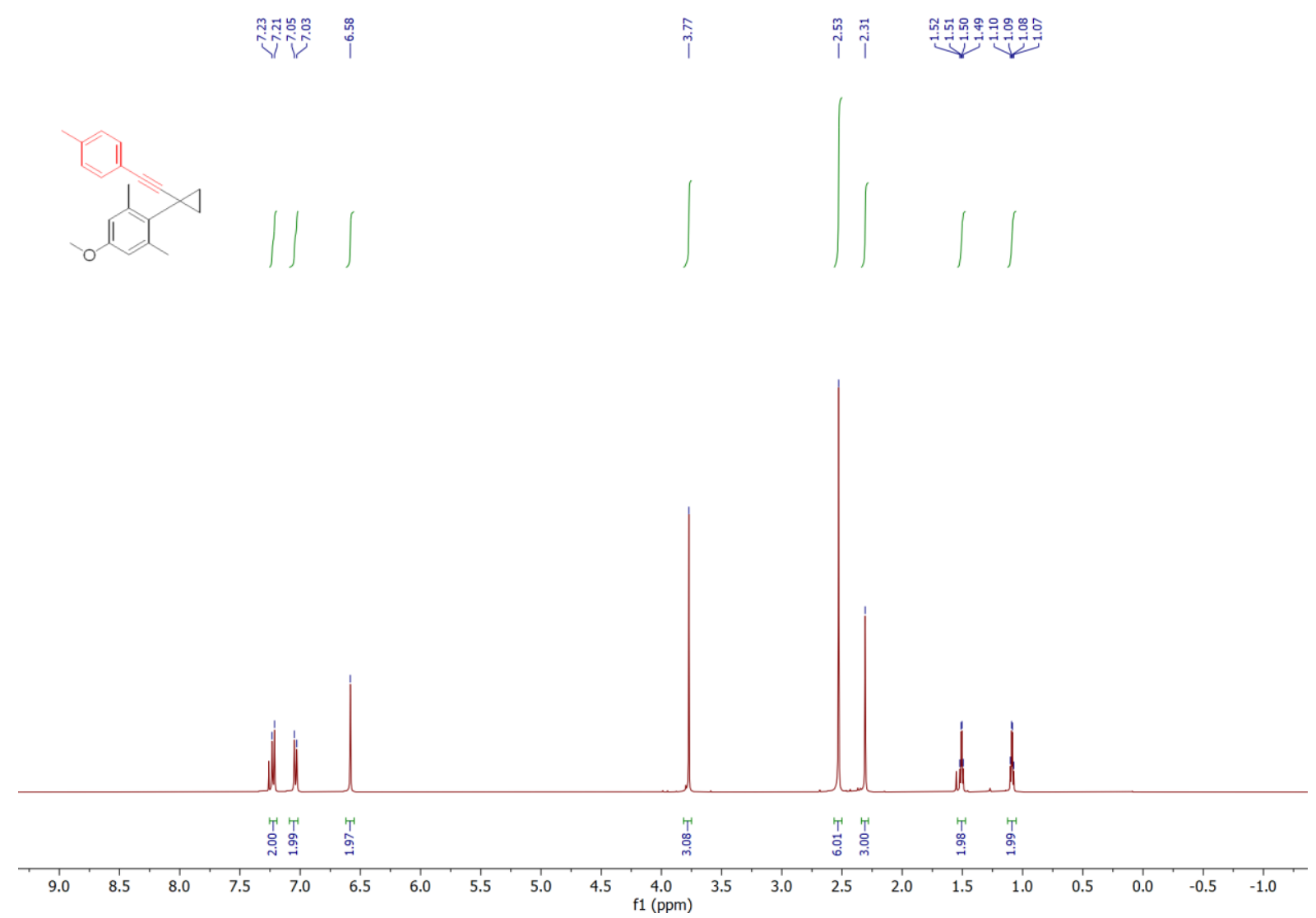

${ }^{13} \mathrm{C}$ NMR (101 MHz, $\mathrm{CDCl}_{3}$ ) (4b)

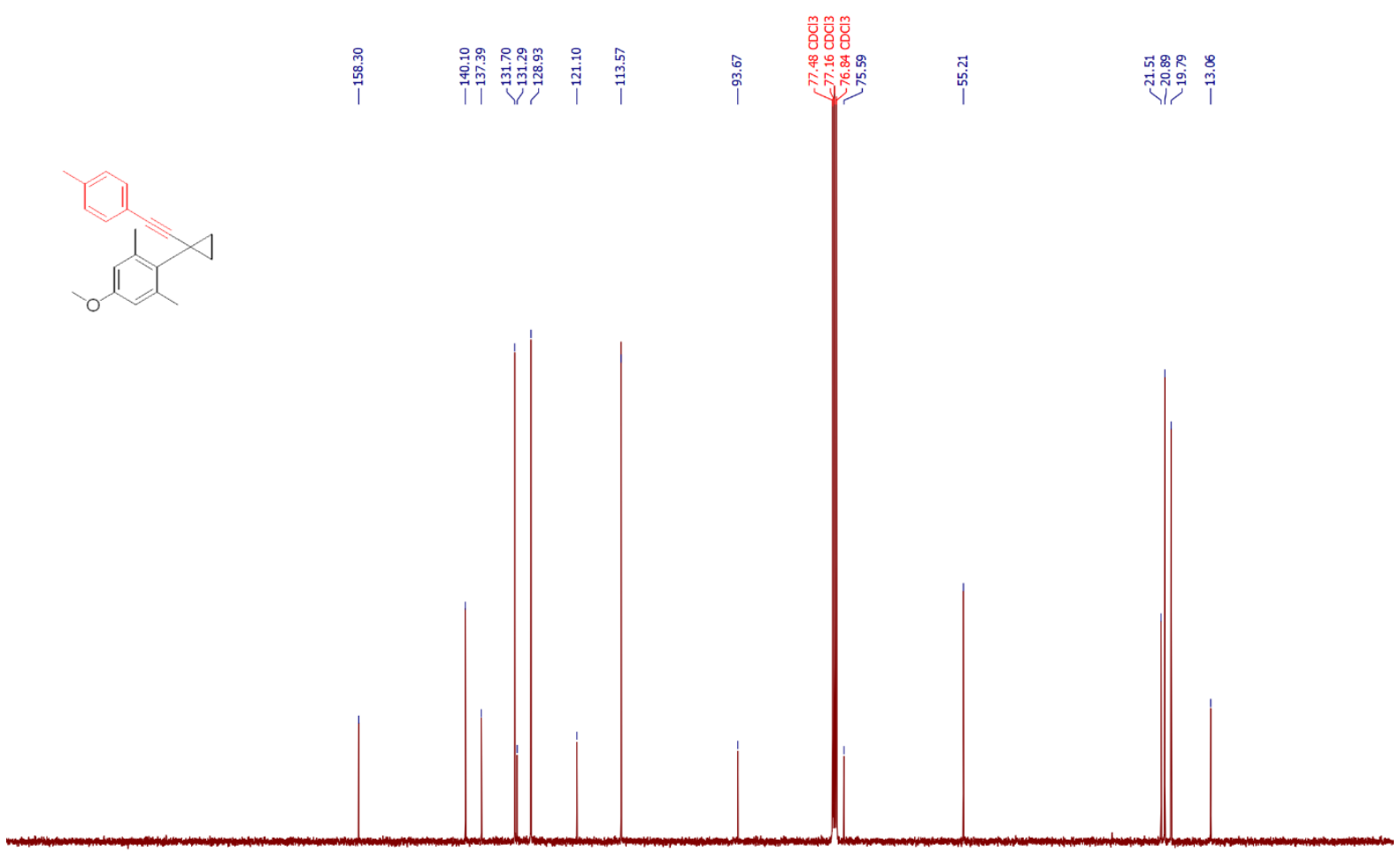

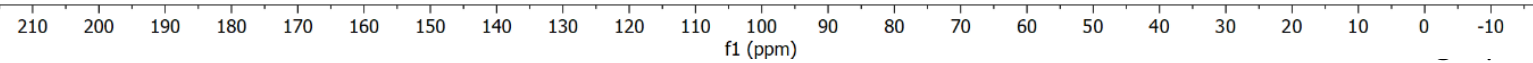


${ }^{1} \mathrm{H}$ NMR (400 MHz, $\mathrm{CDCl}_{3}$ ) (4c)

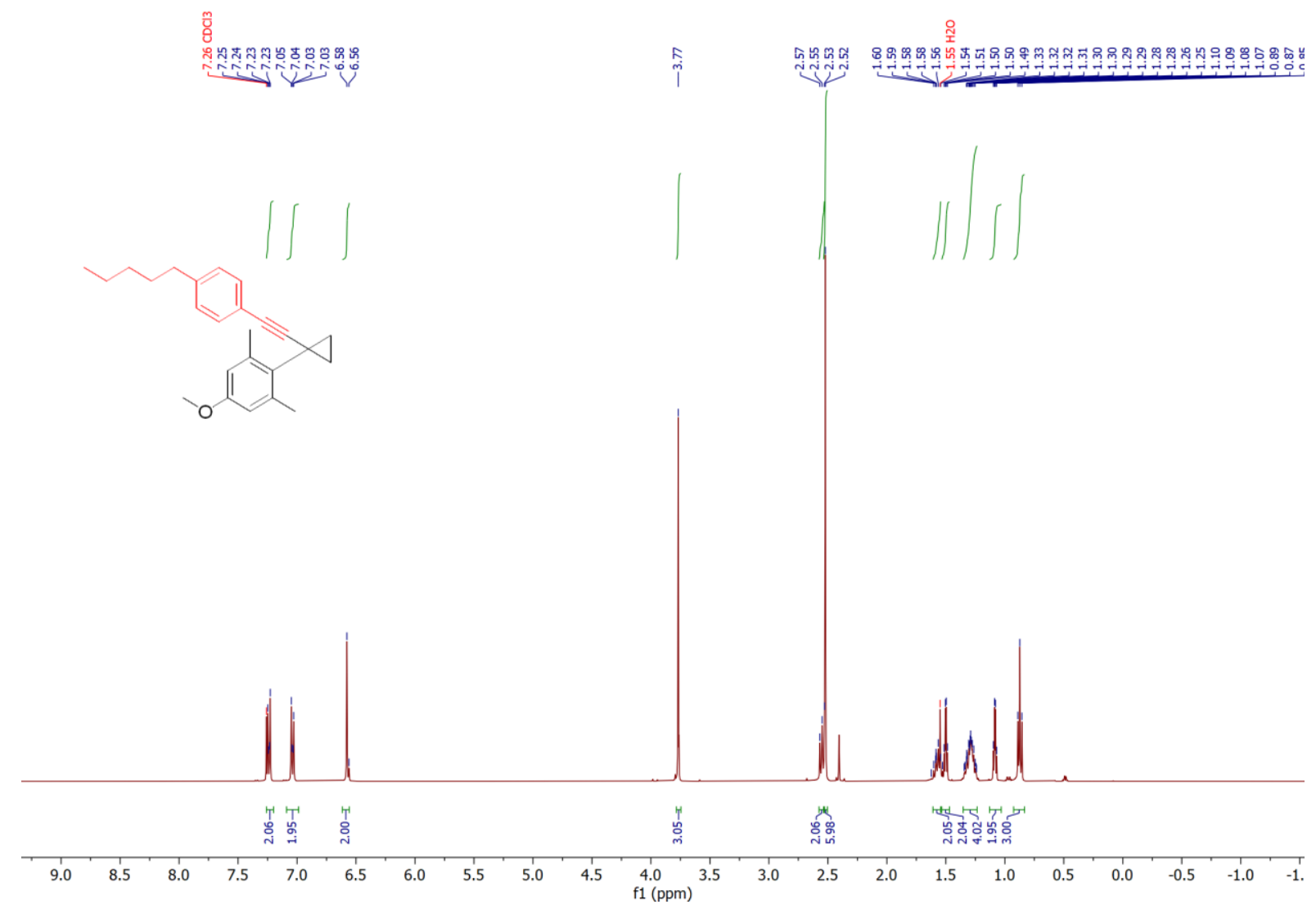

${ }^{13} \mathrm{C}$ NMR (101 $\left.\mathrm{MHz}, \mathrm{CDCl}_{3}\right)(4 \mathrm{c})$

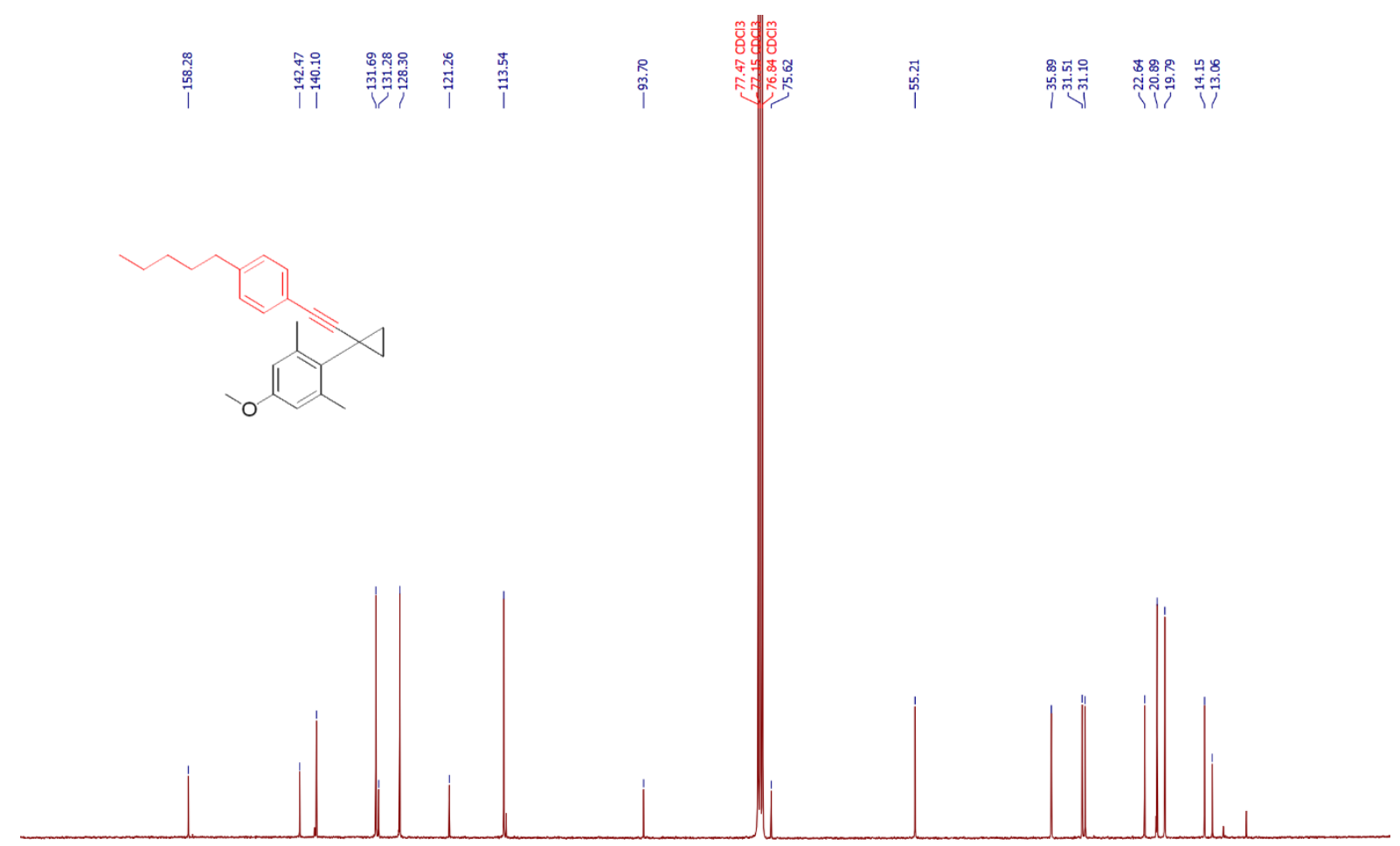

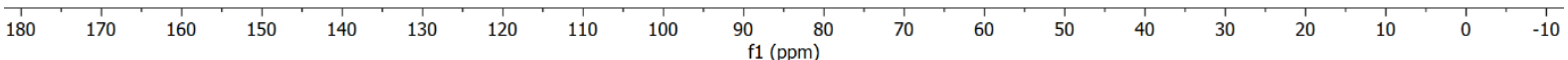


${ }^{1} \mathrm{H}$ NMR (400 MHz, $\mathrm{CDCl}_{3}$ ) (4d)

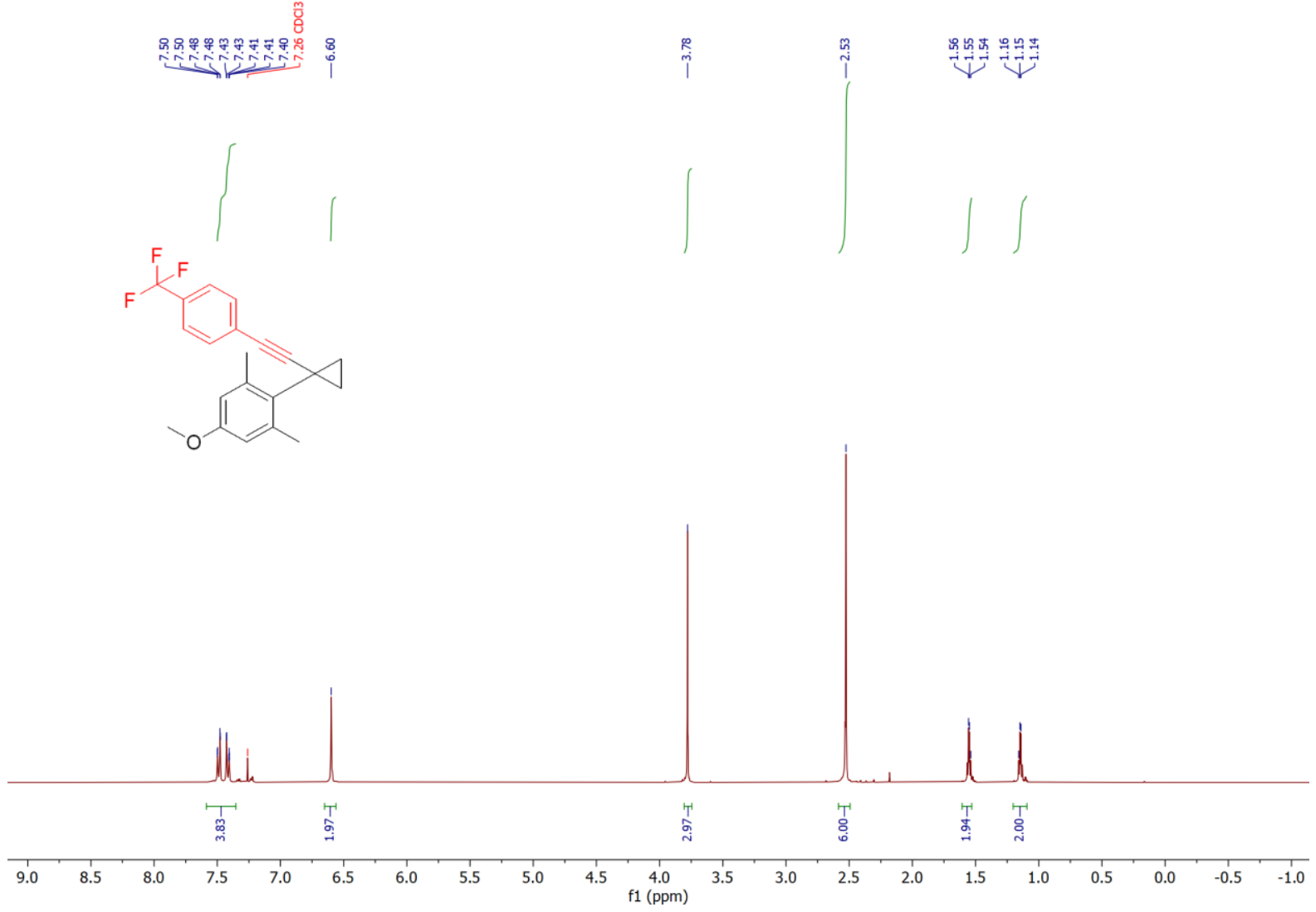

${ }^{13} \mathrm{C}$ NMR (101 MHz, $\left.\mathrm{CDCl}_{3}\right)(4 \mathrm{~d})$

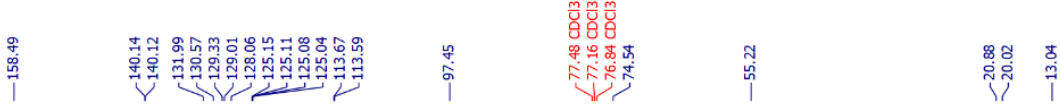
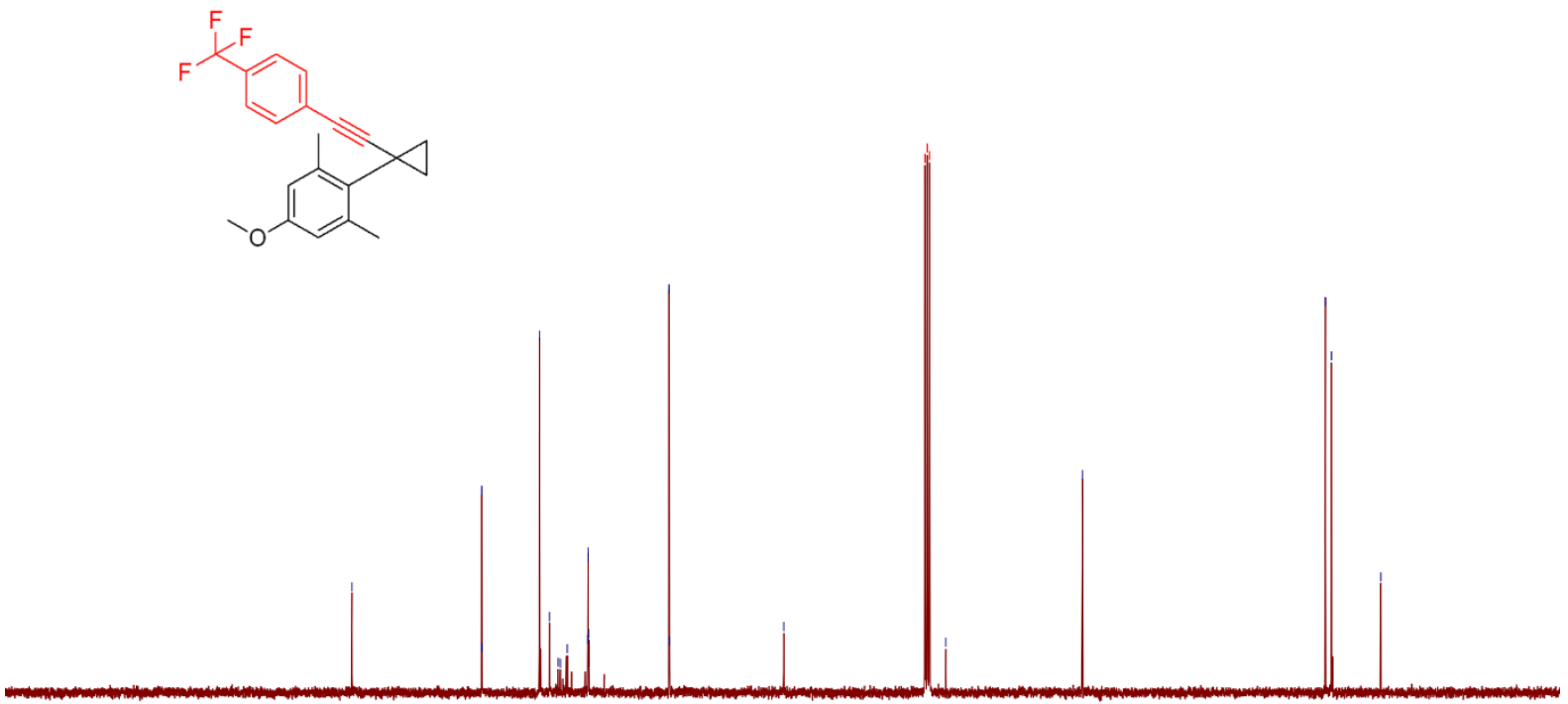

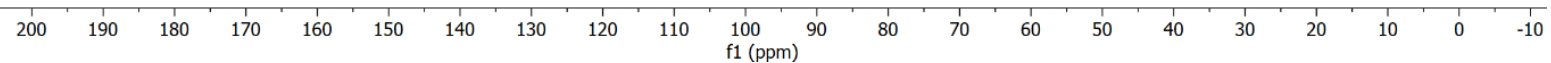


$\left.{ }^{19} \mathrm{~F} \mathrm{NMR} \mathrm{(377} \mathrm{MHz,} \mathrm{CDCl}_{3}\right)(4 \mathrm{~d})$
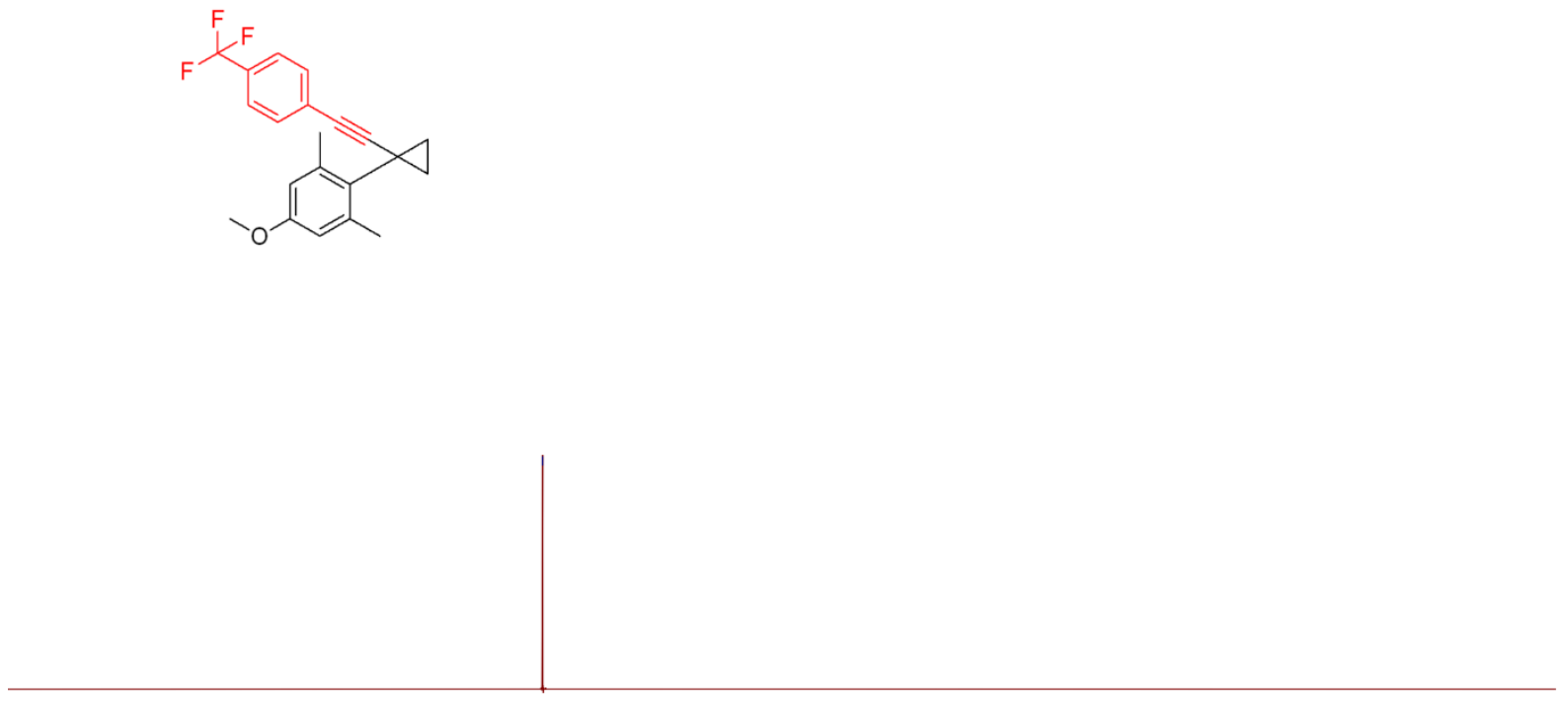

$\begin{array}{llllllllllllllllllllllllllllllllll}10 & 10 & 0 & -10 & -20 & -30 & -40 & -50 & -60 & -70 & -80 & -90 & -10 & -110 & -120 & -130 & -140 & -150 & -160 & -170 & -180 & -190 & -200 & -210 & -24\end{array}$ 
${ }^{1} \mathrm{H}$ NMR (400 MHz, $\mathrm{CDCl}_{3}$ ) (4e)
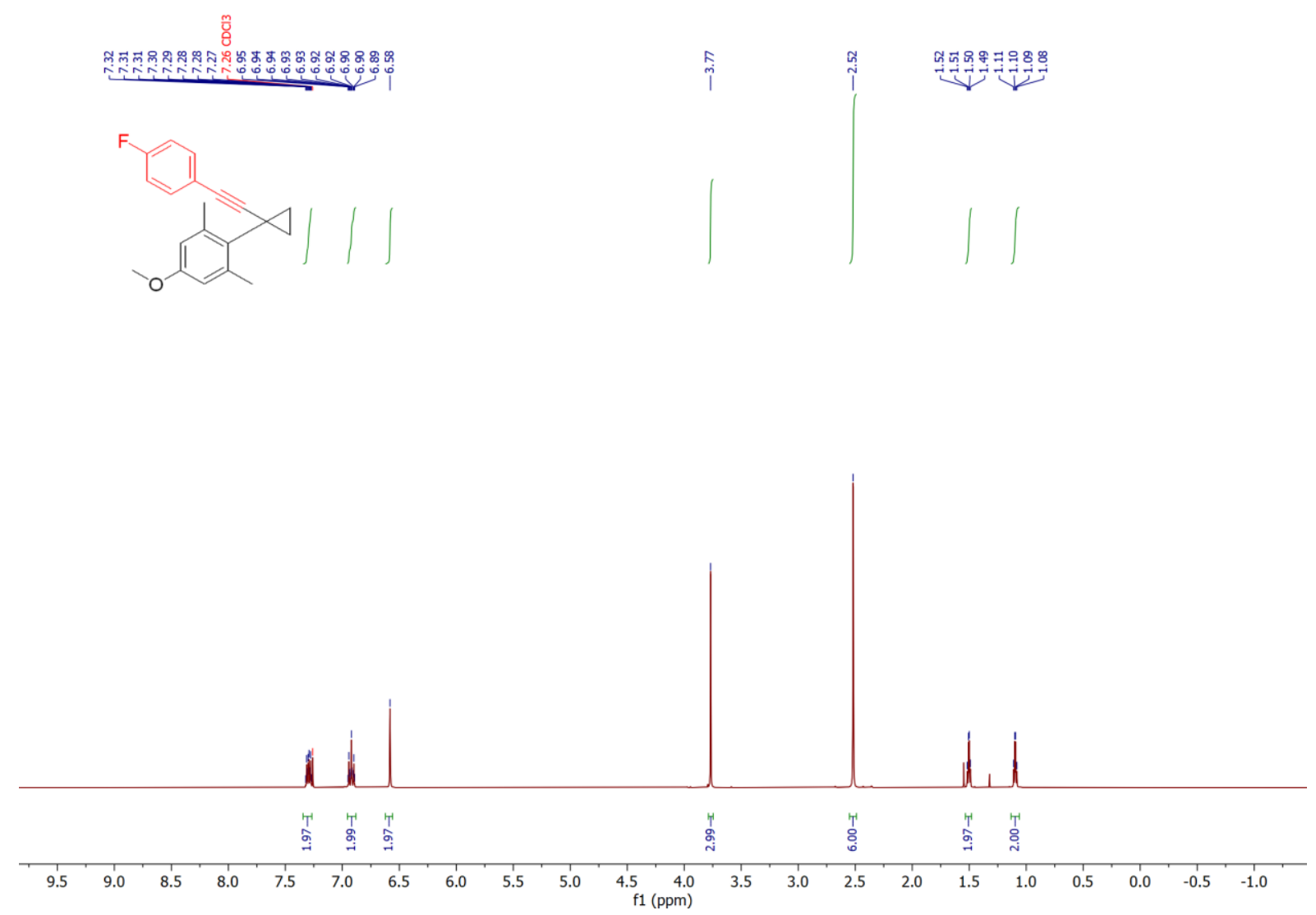

${ }^{13} \mathrm{C}$ NMR (101 $\left.\mathrm{MHz}, \mathrm{CDCl}_{3}\right)(4 \mathrm{e})$

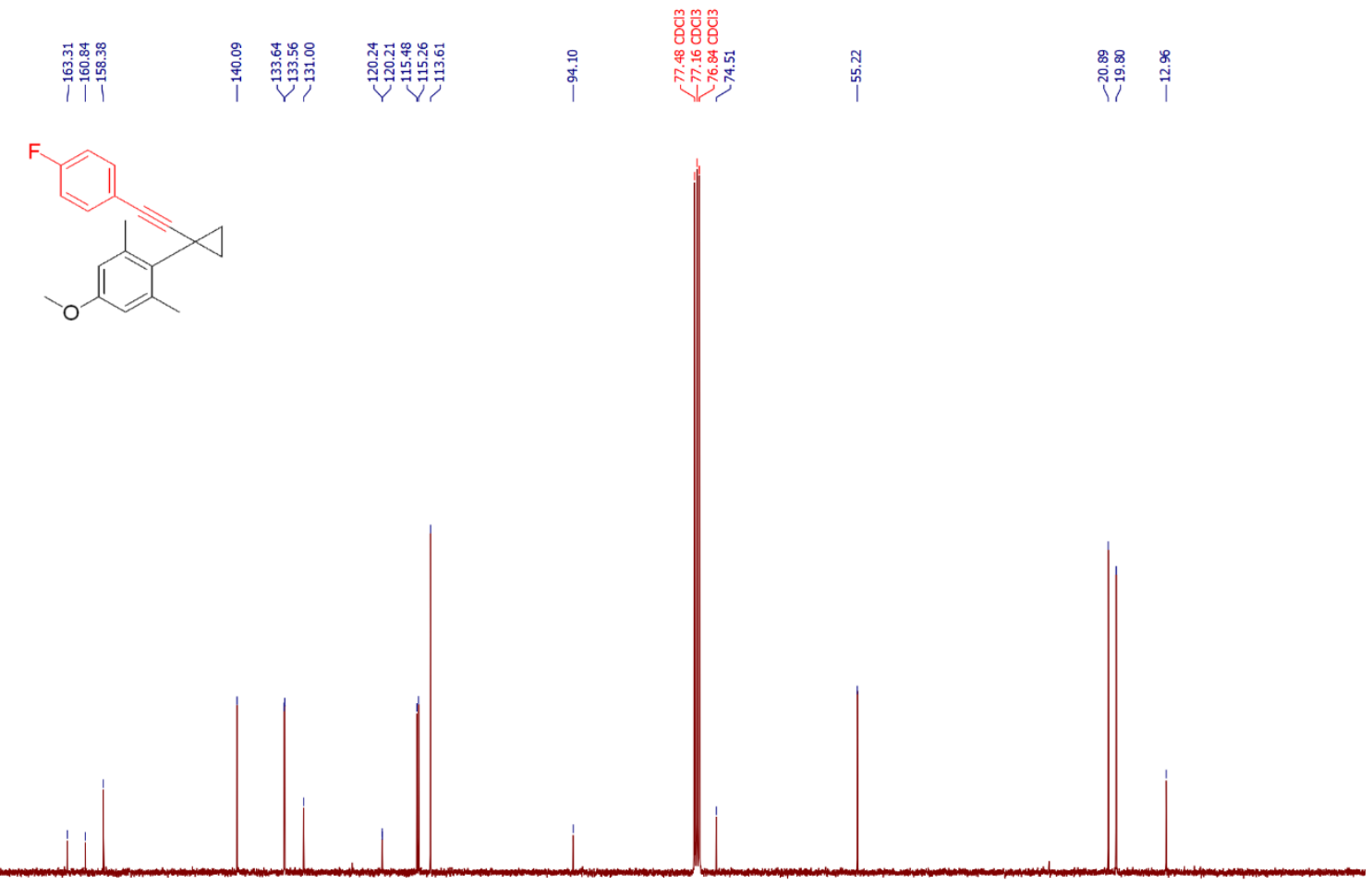

180

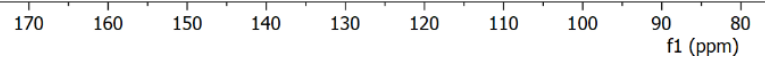

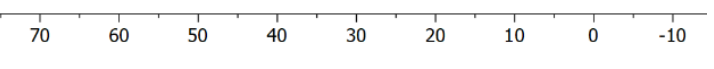

Page | 89 
${ }^{19}$ F NMR (377 MHz, $\left.\mathrm{CDCl}_{3}\right)$ (4e)

$$
\text { 栗 }
$$<smiles>COc1cc(C)c(C2CC2)c(C23C=CC2C3)c1</smiles>

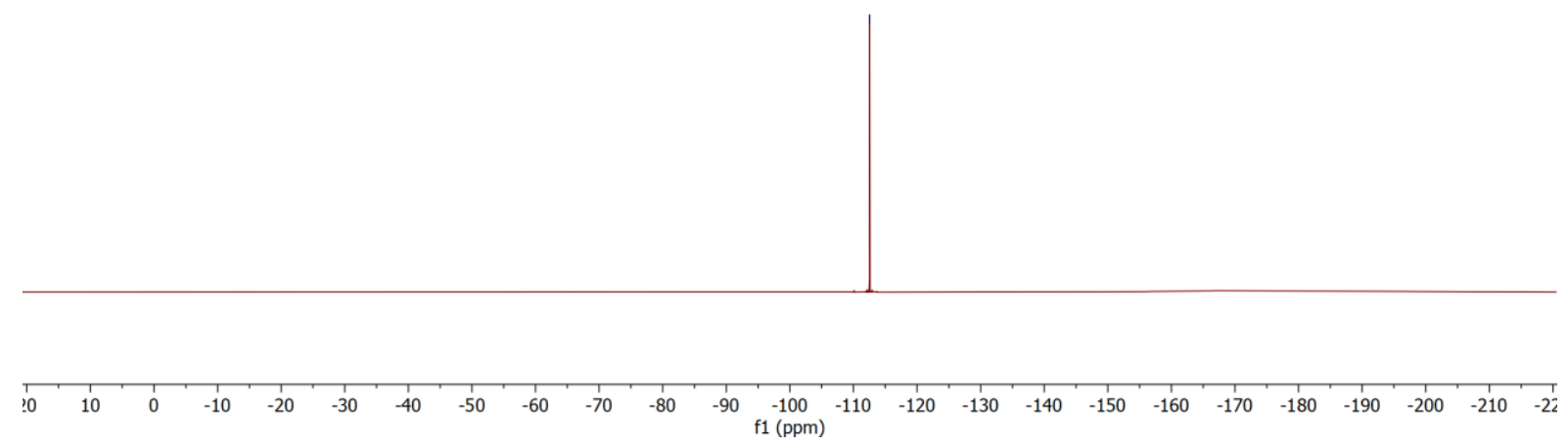


${ }^{1} \mathrm{H}$ NMR (400 MHz, $\left.\mathrm{CDCl}_{3}\right)(4 \mathrm{f})$
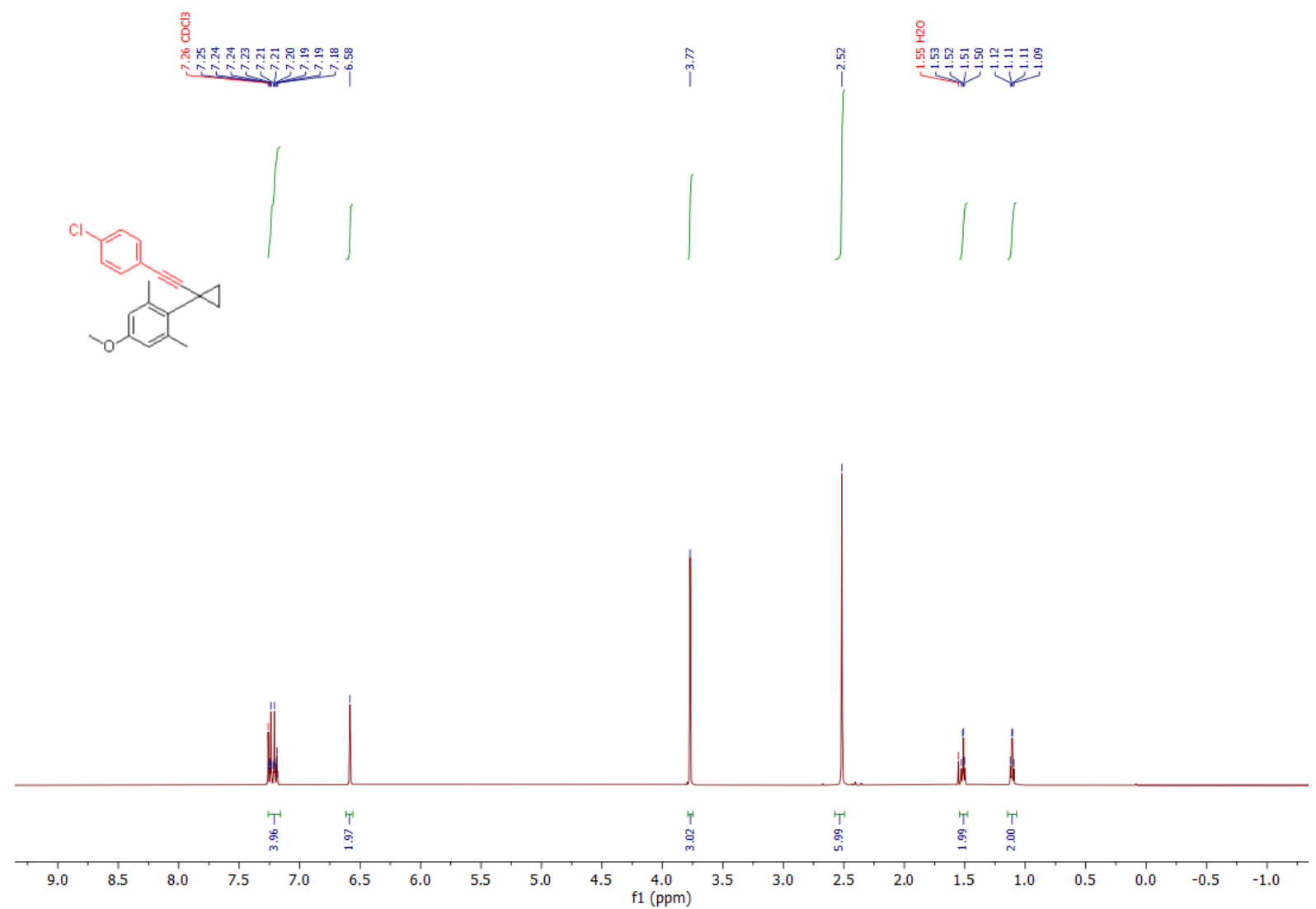

${ }^{13} \mathrm{C}$ NMR (101 MHz, $\left.\mathrm{CDCl}_{3}\right)(4 \mathrm{f})$
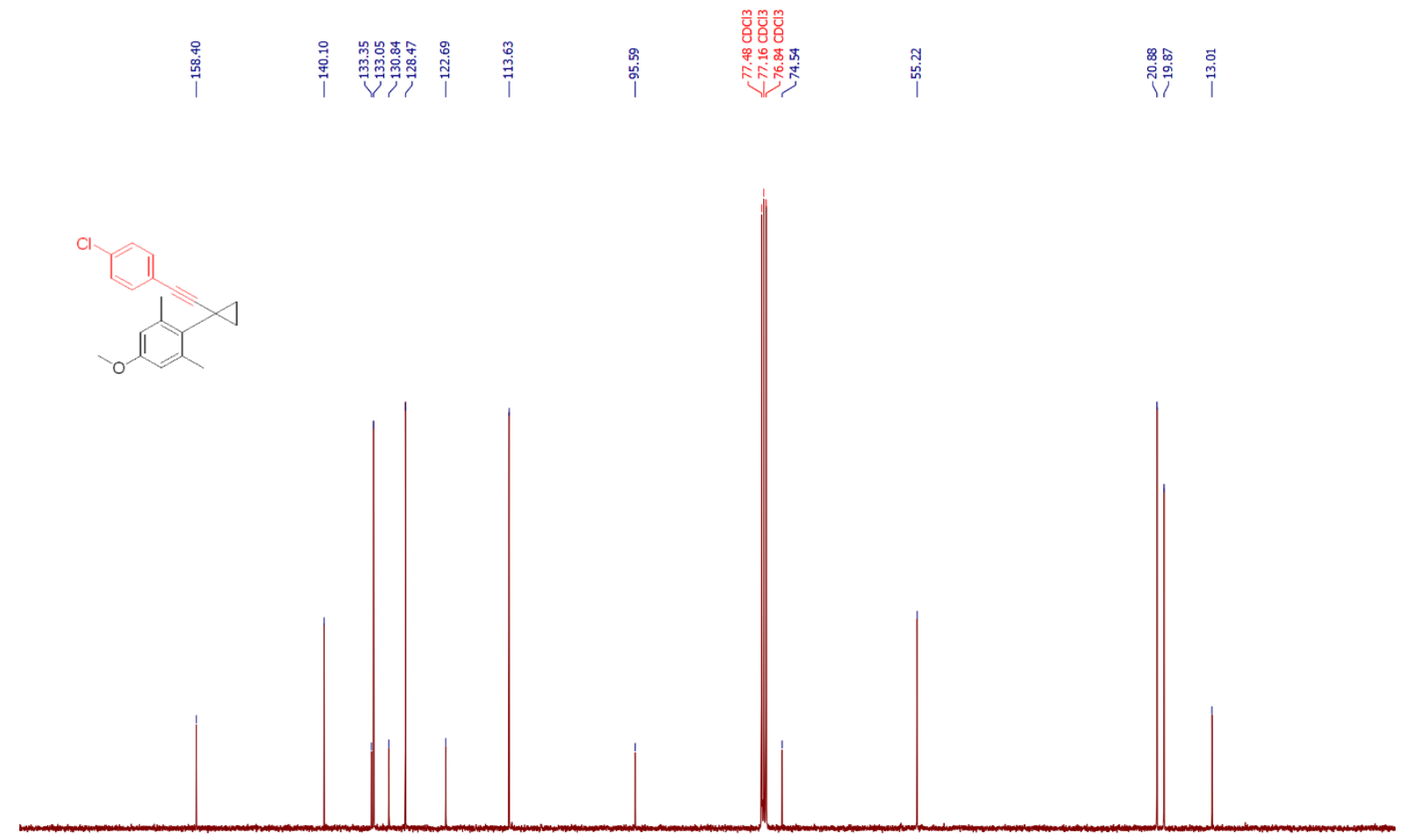

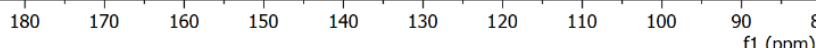


${ }^{1} \mathrm{H}$ NMR (400 MHz, $\mathrm{CDCl}_{3}$ ) (4g)

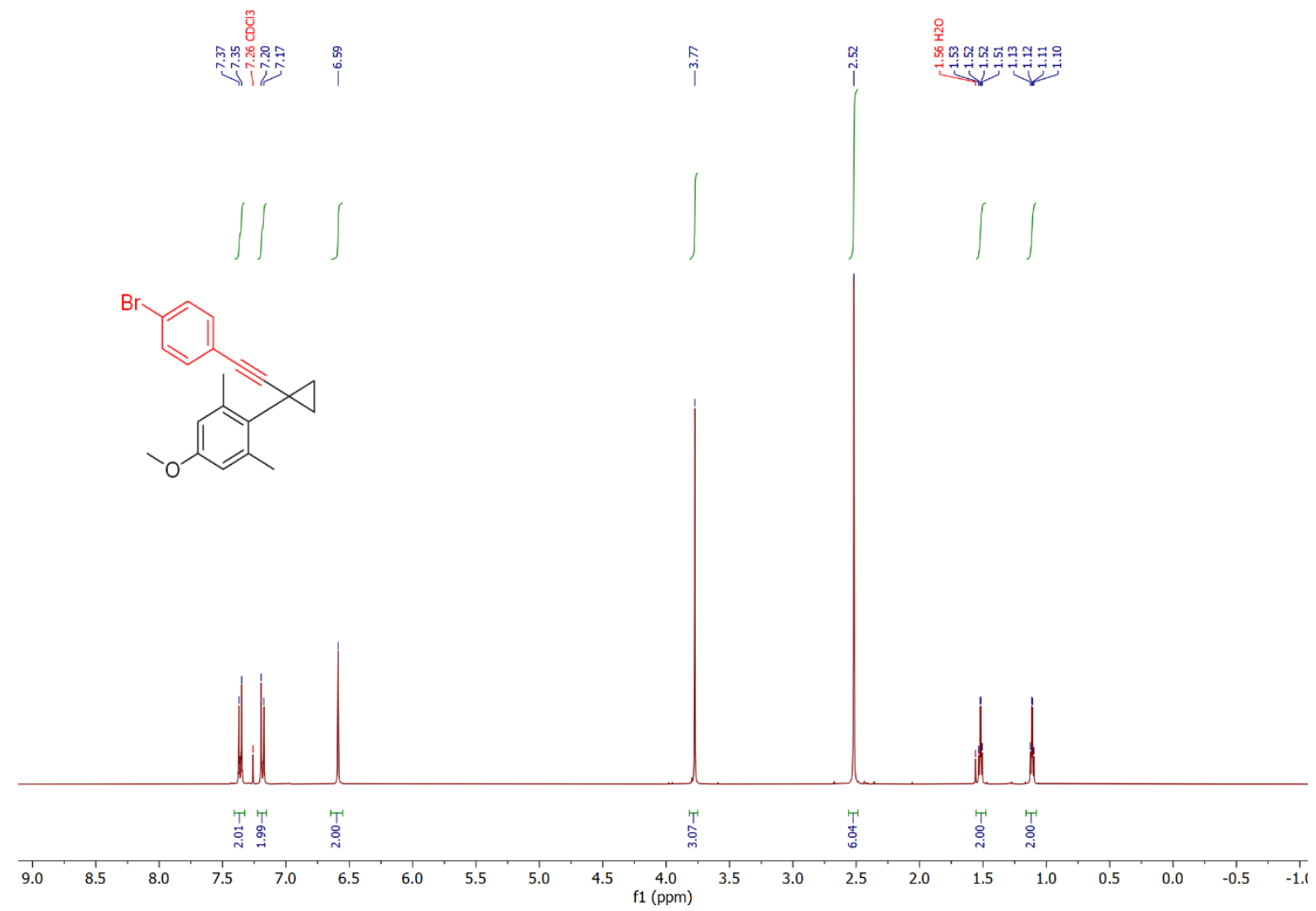

$\left.{ }^{13} \mathrm{C} \mathrm{NMR} \mathrm{(101} \mathrm{MHz,} \mathrm{CDCl}_{3}\right)(4 \mathrm{~g})$
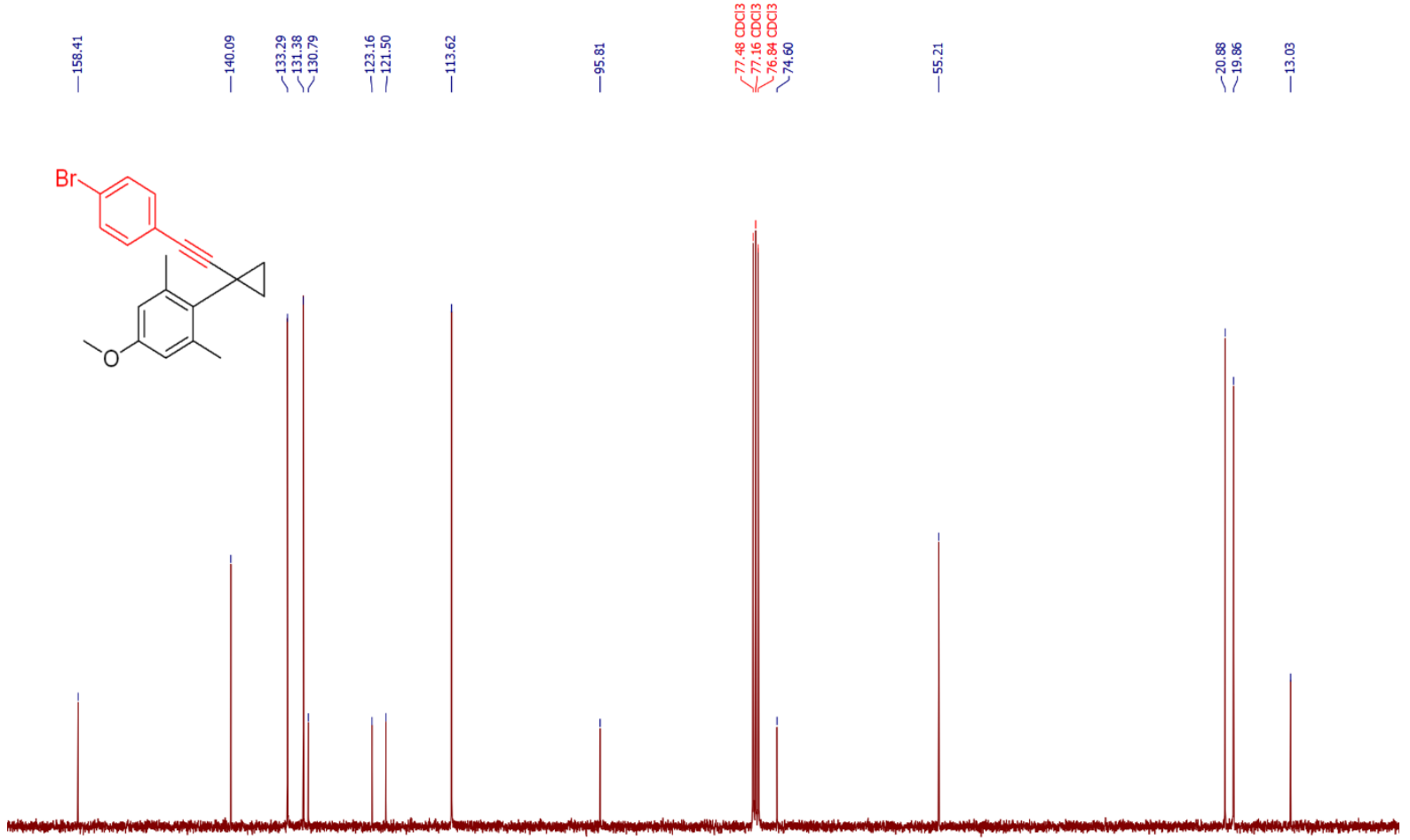

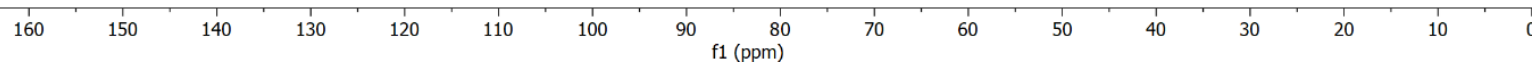


${ }^{1} \mathrm{H}$ NMR (400 MHz, $\mathrm{CDCl}_{3}$ ) (4h)

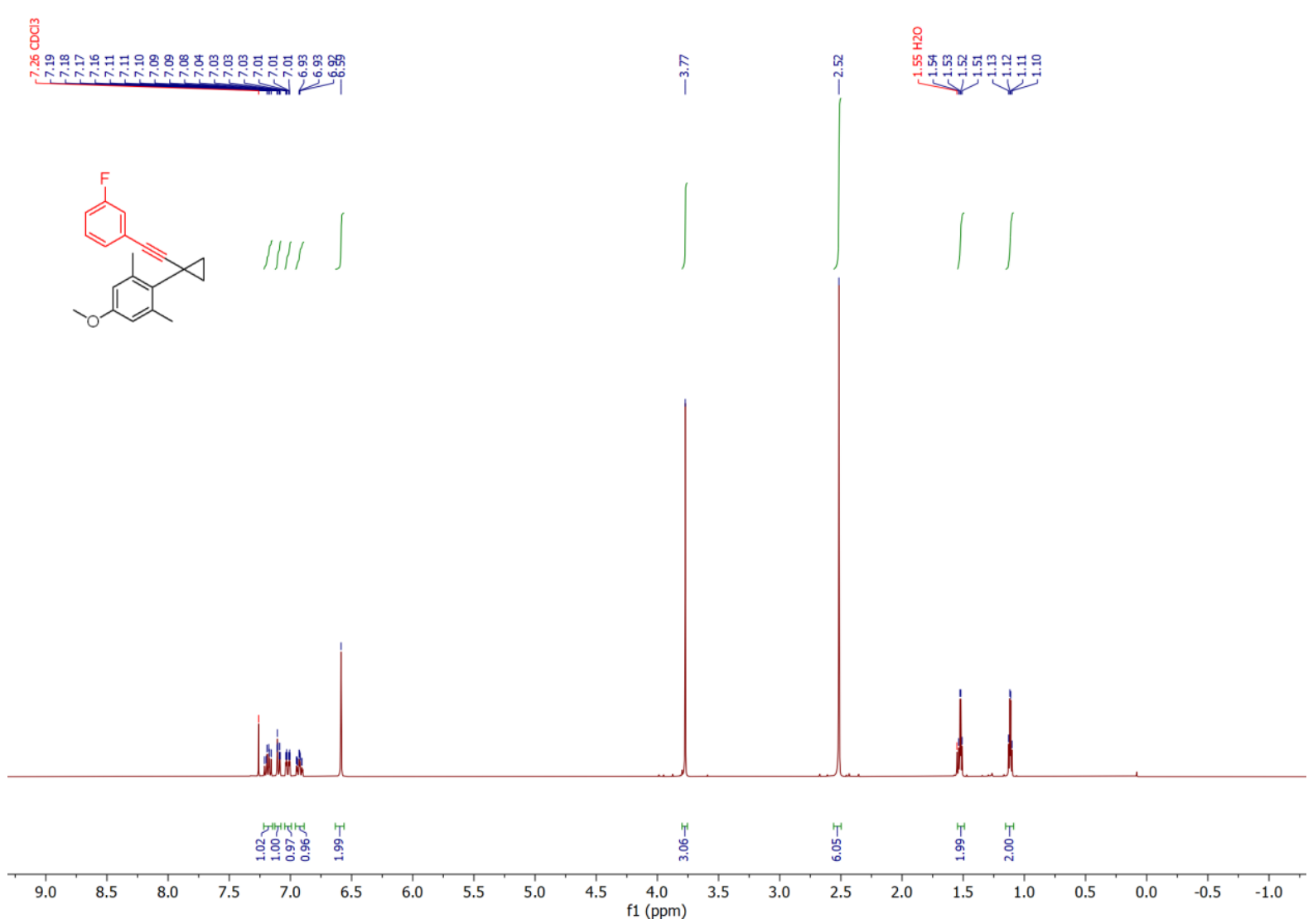

${ }^{13} \mathrm{C}$ NMR (101 MHz, $\mathrm{CDCl}_{3}$ ) (4h)

Page | 93 
${ }^{19}$ F NMR (377 MHz, $\left.\mathrm{CDCl}_{3}\right)(4 \mathrm{~h})$

$\stackrel{\mathscr{0}}{\mathrm{i}}$
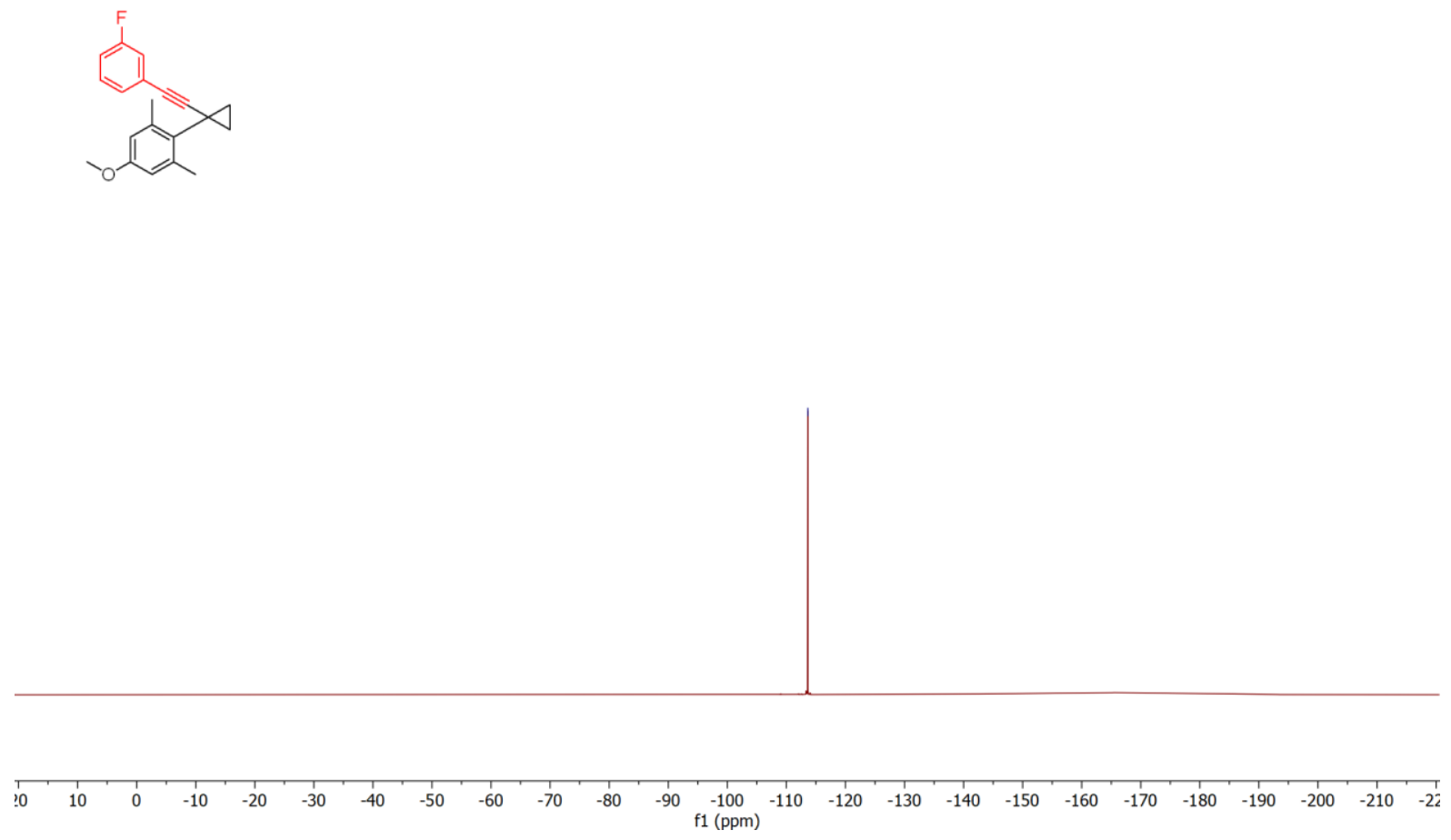

Page | 94 
${ }^{1} \mathrm{H}$ NMR (400 MHz, $\mathrm{CDCl}_{3}$ ) (4i)

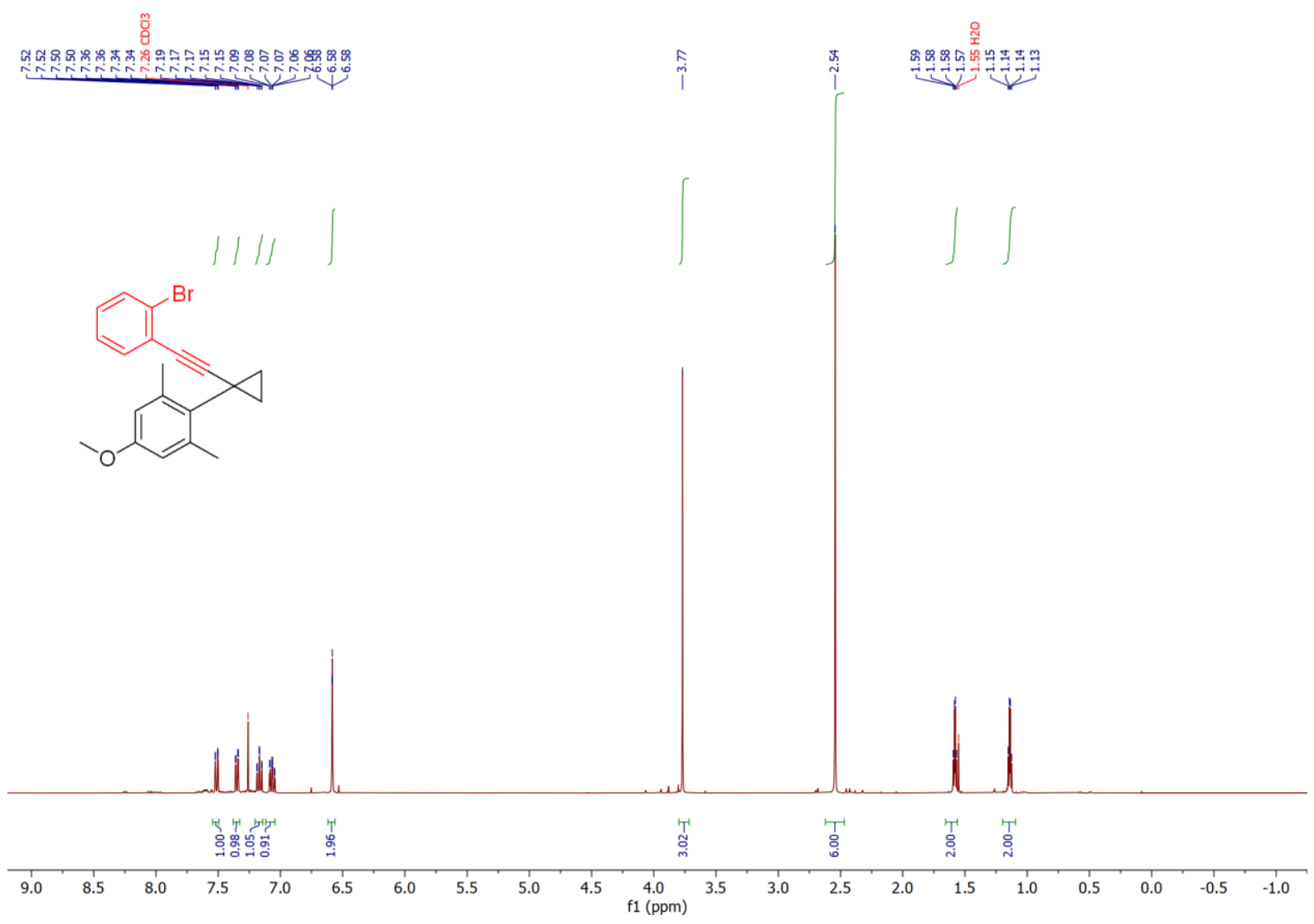

${ }^{13} \mathrm{C}$ NMR (101 MHz, $\left.\mathrm{CDCl}_{3}\right)(4 \mathrm{i})$
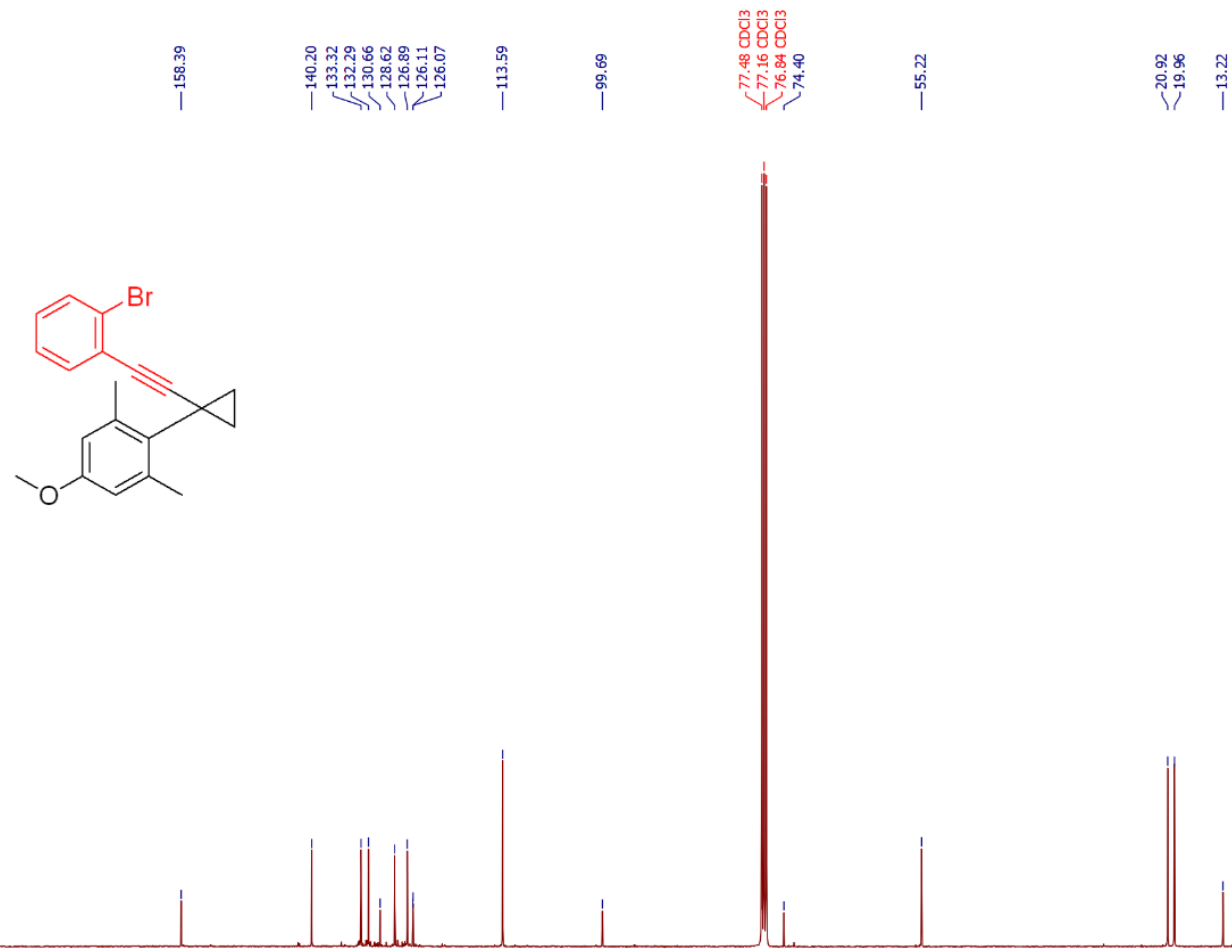

$\begin{array}{rllllllllll}200 & 190 & 180 & 170 & 160 & 150 & 140 & 130 & 120 & 110 & 100 \begin{array}{r}90 \\ \mathrm{f} 1(\mathrm{ppm})\end{array}\end{array}$ 


\section{References}

(1) Petzold, Daniel, Pardeep Singh, Fredrik Almqvist, and Burkhard Koenig. "Visible-LightMediated Synthesis of $\beta$-Chloro Ketones from Aryl Cyclopropanes." Angewandte Chemie International Edition 58, no. 25 (2019): 8577-8580.

(2) Gieuw, Matthew H., Zhihai Ke, and Ying-Yeung Yeung. "Lewis Base-Promoted RingOpening 1, 3-Dioxygenation of Unactivated Cyclopropanes Using a Hypervalent lodine Reagent." Angewandte Chemie 130, no. 14 (2018): 3844-3848.

(3) Ge, Liang, Ding-Xing Wang, Renyi Xing, Di Ma, Patrick J. Walsh, and Chao Feng. "Photoredox-catalyzed oxo-amination of aryl cyclopropanes." Nature communications 10, no. 1 (2019): 1-9.

(4) Ernst, Ludger, Thomas Rieck, and Mark Soliven. "Preferred conformation and barriers to internal rotation of ortho-disubstituted cyclopropylbenzenes." Canadian journal of chemistry 77, no. 11 (1999): 1697.

(5) Wang, Ming-Ming, Tin VT Nguyen, and Jerome Waser. "Diamine Synthesis via the Nitrogen-Directed Azidation of $\sigma$-and $\pi-C-C$ Bonds." Journal of the American Chemical Society 143, no. 31 (2021): 11969-11975.

(6) Liu, Zhengyi, Shuang Wu, and Yiyun Chen. "Selective C (sp3)-C (sp3) Cleavage/Alkynylation of Cycloalkylamides Enables Aminoalkyne Synthesis with Hypervalent lodine Reagents." ACS Catalysis 11, no. 16 (2021): 10565-10573.

(7) Le Vaillant, Franck, Thibaut Courant, and Jerome Waser. "Room-Temperature Decarboxylative Alkynylation of Carboxylic Acids Using Photoredox Catalysis and EBX Reagents." Angewandte Chemie 127, no. 38 (2015): 11352-11356..

(8) Amos, Stephanie GE, Stefano Nicolai, and Jerome Waser. "Photocatalytic Umpolung of $\mathrm{N}$-and O-substituted alkenes for the synthesis of 1, 2-amino alcohols and diols." Chemical science 11, no. 41 (2020): 11274-11279.

(9) Amos, Stephanie GE, Diana Cavalli, Franck Le Vaillant, and Jerome Waser. "Direct Photoexcitation of Ethynylbenziodoxolones: An Alternative to Photocatalysis for Alkynylation Reactions." Angewandte Chemie International Edition 60, no. 44 (2021): 23827-23834.

(10) Zhang, Ruo-Yi, Long-Yi Xi, Lei Shi, Xiao-Zhuan Zhang, Shan-Yong Chen, and Xiao-Qi Yu. "Metal-Free Oxidative Radical Alkynylation/Ring Expansion Rearrangement of Alkenyl Cyclobutanols with Ethynylbenziodoxolones." Organic letters 18, no. 16 (2016): 40244027.

(11) Le Vaillant, Franck, Marion Garreau, Stefano Nicolai, Ganna Gryn'ova, Clemence Corminboeuf, and Jerome Waser. "Fine-tuned organic photoredox catalysts for 
fragmentation-alkynylation cascades of cyclic oxime ethers." Chemical science 9, no. 27 (2018): 5883-5889..

(12) Fernandez Gonzalez, Davinia, Jonathan P. Brand, Regis Mondiere, and Jerome Waser. "Ethynylbenziodoxolones (EBX) as reagents for the ethynylation of stabilized enolates." Advanced Synthesis \& Catalysis 355, no. 8 (2013): 1631-1639. 